\title{
BIODEGRADABLE BUILDING: A ZERO-WASTE MEDIUM DENSITY HOUSING DESIGN FOR NEW ZEALAND
}

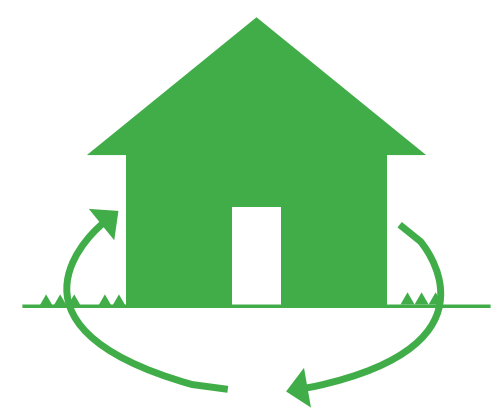




\section{Abstract}

New Zealand has a serious construction and demolition (C\&D) waste issue. A Ministry for the Environment study from 2019 found that 2.9 million tonnes of C\&D waste are disposed of at C\&D fills nationwide every year (Ministry for the Environment, 2019). Averaged across the population this equates to nearly $600 \mathrm{~kg}$ per person. Auckland Council's 'Low Carbon Auckland' plan presents total landfill waste reduction targets of 30\% by 2020, 60\% by

To achieve this goal of zero waste, building materials must operate within a closed loop (Baker-Brown, 2017; McDonough \& Braungart, 2002). Materials can either be a part of a closed organic loop (natural biodegradable materials) or a closed technical loop (man-made cycle of reuse) (Baker-Brown, 2017; McDonough \& Braungart, 2002).

This thesis aims to achieve a zero-waste medium the use of it is hypothesised along with Sassi (2006) that both biodegradable and reusable components will be required to achieve zero waste. This thesis also seeks the most suitable biodegradable materials for New Zealand's climate and the optimum construction approach to support these materials. This research also contributes towards reducing the enbodied energy and greenhouse gas emissions of the New Zealand building industry.

The most suitable biodegradable materials for New Zealand were selected based on availability and performance found to be untreated timber, Clay plaster and, straw and wool insulation. In-situ construction, prefabricated wall panels and, standardised block modules were then compared to ind the most suitable construction approach to support

these materials and was found to be prefabricated wall panels. A building design was then pursued driven by the need to protect the biodegradable insulation materials from moisture infiltration. The design is then integrated within a site in Upper Hutt to address the demand for housing densification and demonstrate the potential for application of biodegradable materials to an urban setting .

A detailed BIM model of the building design was produced from which volumes of individual components were extracted and categor ised regarding their biodegradability or reusability or lack thereof. This was done to determin the proportion and quantity of biodegradable materials and waste generated by the design. An identical design using conventional New Zealand materials and construction techniques was also produced for comparison.

Biodegradable materials made up $82 \%$ of the final design construction by volume and $91 \%$ of the construction by volume was diverted from landfill (reusable components made up $9 \%$ of the construction). This suggests that Auckland Council's goal of $60 \%$ waste reduction by 2030 is theoretically possible for developments of a similar scale to the final design. However, the goal of 'zero waste' by 2040 seems unobtainable even if significant improvements are made. 


\section{Acknowledgements}

I would like to thank my supervisor Hans-Christian Wilhelm who generously poured out his time and energy weekly into my research. I would also like to thank my parents James and Julia Coleman who have supported and encouraged me throughout my studies and particularly during this thesis year. And I am forever grateful to my biggest supporter and wife Gabrielle who has never ceased supporting me at every step of the way. But above all, I am grateful to God, whose goodness and kindness has never left me. 


\section{Contents}

Abstract 3

Acknowledgements

5

Contents 6

Research Outline 9

1.1 Problem Statement 10

1.2 Background 11

1.3 Objectives $\quad 14$

1.4 Hypothesis 14

1.5 Research Question 15

1.6 Relevance/Scope 16

1.7 Methodology 17

\section{Literature Review 20}

2.1 Biodegradable Vernacular Architecture 21

2.2 Biodegradable Contemporary Architecture 24

2.3 Māori Biodegradable Vernacular Architecture 33

2.4 Biodegradable Architecture of the Early Settlers

2.5 Biodegradable Architecture in NZ Today 35

2.6 List of Biodegradable Materials 36

Most Suitable Biodegradable Materials For New Zealand

3.2 Structural Systems 40

3.3 Wall Insulation 46

3.4 Wall Cladding 52

3.5 Foundations 59

3.6 Flooring 62

3.7 Roofing 66

3.8 Summary of Zero Waste Materials for NZ

3.9 Biosphere Barriers 71

\section{Construction Approach Exploration $\mathbf{7 3}$}

4.1 In-situ Construction 75

4.2 Standardised Block Module84

4.3 Prefabricated Wall Panels 91

4.4 Review of Construction Approaches
Form Exploration 106

5.2 Concept $1 \quad 109$

5.3 Concept $2 \quad 116$

5.4 Concept $3 \quad 121$

5.5 Review of Concept Designs 125

Site Integration 126

6.1 Selected Site 127

6.2 Medium Density Housing Precedents 129

6.3 Site Development Proposal 131

\section{Detailed Design 141}

7.1 Prefabricated Panel Development and Integration 143

7.2 Final Design and Conventional Design Comparison 150

7.4 Biodegradable and Reusable Definitions159

7.3 End of Life Analysis 160

7.5 Discussion 169

7.8 Techsphere Barriers 169

Conclusion 170

Limitations 171

Further Research 171

Reference List

Appendices 176 
Research Outline 


\subsection{Problem Statement}

\section{Construction and Demolition Waste}

Construction and demolition waste is a global issue. In 2012, 40 countries collectively produced more than 3 billion tonnes of building waste and this figure has been ncreasing every year (Akhtar \& Sarmah, 2018)

Despite the clean green image of New Zealand, there is a severe issue with the amount of building waste produced here and it is contributing to this global issue. In 2014, it was estimated that C\&D waste represented $50 \%$ of al waste generated in New Zealand by weight (BRANZ, 2014). In 2018. Auckland Council released the region's Waste Management and Minimisation Plan (WMMP) in which it sted CQD waste to be the largest single waste stream for the region, at around $40 \%$ of total weight going to and maxlly

\section{Waste Reduction Targets}

Auckland Council's 'Low Carbon Auckland' plan presents total landfill waste reduction targets of $30 \%$ by weight by 020, 60\% by 2030, and 'zero wate' by 2040 (Auckland 2020 target has been achien Previously to these targets from Auckland Council in 2002 New Zealand set the goal of reducing CCD waste going to landfills by $50 \%$ of the 2005 figure by 2008 (Ministry for the Environment 2002). By 2005 , half of the Territorial Authorities in New Z 2002). By 2005, half of the Territorial (Storey et a 2005). The fact that similar targets have A

Figure 2

Linear Economy diagram

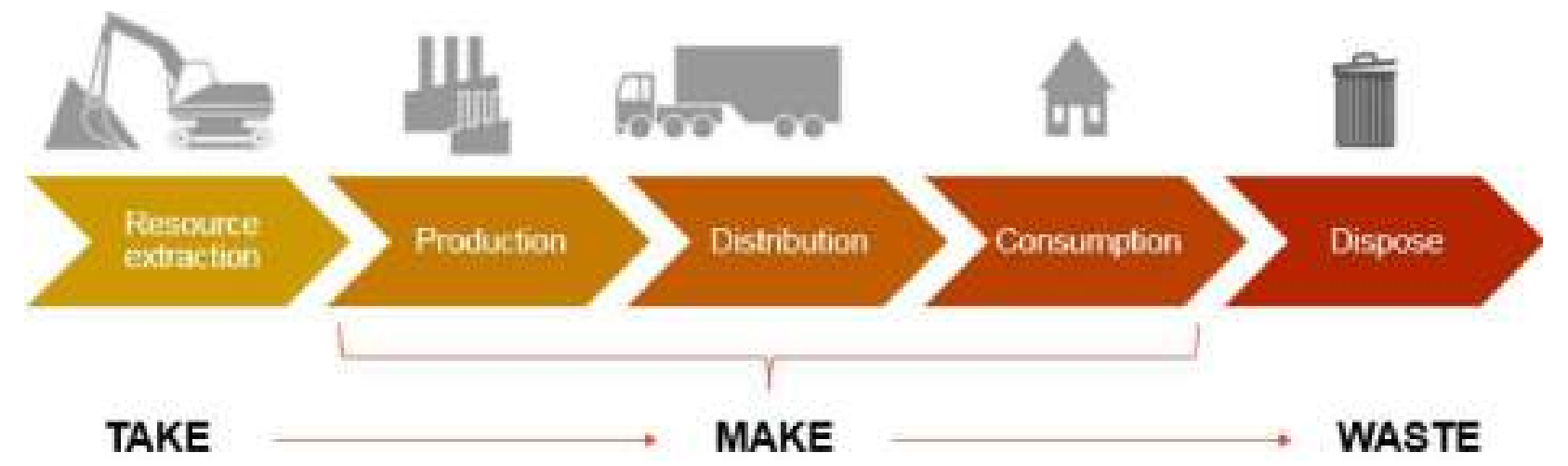

Figure 1

Construction and Demolition Waste

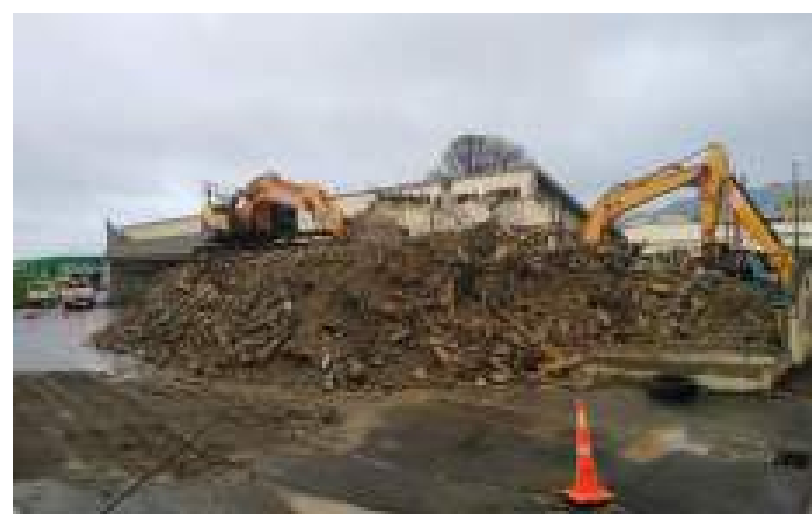

Photograph by Jacob Coleman, 2020

\section{Linear Economy}

The issue is in the way we build in New Zealand. Our building materials are not in a closed loop. Most of our building materials and components in New Zealand fall into a linear life system, where a material is extracted, produced, distributed, consumed, and finally disposed of This linear system demands the constant production of new materials which places a strain on our planet's finite resources and this constant extraction and production damages our environment through the emissions of greenhouse gases (GHG).

\subsection{Background}

To achieve a zero-waste construction industry, architects must design with materials that operate within a closed loop (Baker-Brown, 2017, McDonough \& Braungart, 2002). This means that the outputs of one system feed directly into the inputs of a new system resulting in no waste. There are two possibe closed loop cycles that materials can be a part of (figure 3) (Baker-Brown, 2017; McDonough $\&$ Braungart, 2002).

\section{Figure 3}

Organic and technical cycle diagram

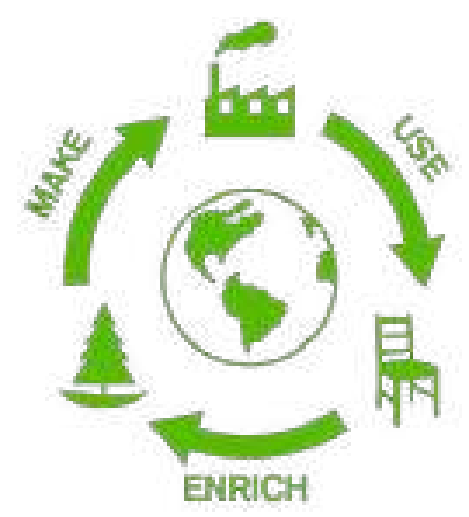

\section{BIO-SPHERE}

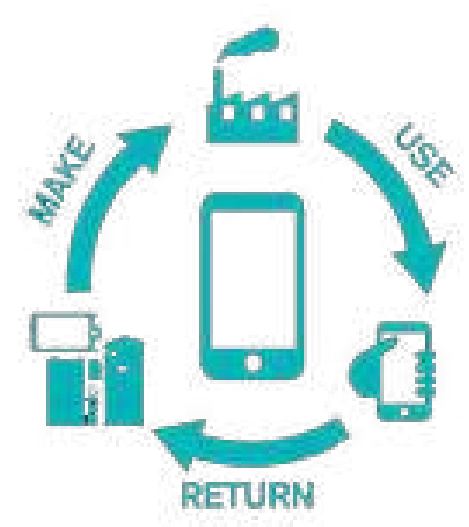

\section{TECH-SPHERE}

Reprinted from "The re-use atlas : a designer's guide towards the circular economy" by D. Baker-Brown, 2017, RIBA Publishing. p. 13. Copyright 2009 by Duncan BakerBrown.
1. Bio-Sphere/Organic Cycle

This can be thought of as nature's cycle. This cycle is exclusive to plant-based materials that naturally regenerate and biodegrade such as wood or straw (McDonough \& Braungart, 2002). The building materials produced from these natural resources often boast low embodied energies due to their lack of processing such as timber or straw bale. Although technically not renewable or biodegradable, earth will be included as material in the bio-sphere for this thesis. This is because earth is a natural material and produces zero-waste because
remains a natural resource not a waste material.

The term biodegradable in this paper is used to refer to materials that operate within the bio-sphere or organic cycle as defined by McDonough and Braungart in their book "Cradle to cradle. Remaking the way we make include

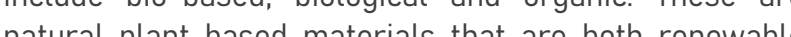
and biodegradable.

Biodegradation is a natural form of waste stabilisation (Haug, 2018). Biodegradation, decomposition or composting occurs when microorganisms (fungi and actinomycetes) macroorganisms (insects), and aerobic bacteria break down plant matter by ingesting and binding the particles together (Dougoud, 2018). The material that is biodegrading provides food for organisms in the form of carbon and nitrogen (Dougoud, 2018). It is important to note here that simply because biodegradable materials can biodegrade doesn't mean they will in any situation. Biodegradation requires special conditions of aeration and moisture to produce thermophilic temperatures (Haug, 2018). These specific conditions can easily be denied while the material carries out its operational life. Biodegradation is further defined for the purpose of developing specific assessment criteria later (see page 159).

2. Tech-sphere/Technical Cycle

This can be thought of as the man-made cycle of reuse. Any reused material participates in this cycle (Baker-Brown, 2017). This cycle is available to all materials or building elements, whether they be renewable, highly-processed, biodegradable or not. Given these materials or components can be carefully removed and disassembled and without integrity or suitability eventually becomes insufficient for application. windows and doors are examples of building elements with potential for reuse.

Reprinted from "Exploring the role of independent retailers in the circular economy: a case study approach" by T. Wautelet, 2018, p. 18. Copyright 2018 by Thibaut Wautelet. 


\section{Both Spheres Can Be Combined}

Both the bio-sphere and the tech-sphere can be combined. This can be thought of simply as the reuse of biodegradable materials. This approach means that the biodegradable component can remain in a technical cycle until it reaches the end of its useable life at which point it can return to its organic cycle and biodegrade (Sassi, 2006). This prolongs the life of the biodegradable material which will lower the frequency at which these matera lives and have to be dealt with.

\section{Zero Waste Design Strategy}

The strategy in this thesis to achieve zero waste is to:

1. Maximise the use of biodegradable building materials

2. Use reusable components where no biodegradable substitutive exists or is wise to use

3. Use deconstruction instead of demolition at the end of life of the building to ensure reuse of reusable components and separation of biodegradable reusable components.

\section{Maximise Biodegradable Materials}

Although both cycles technically result in zero waste, only materials in an organic cycle ultimately do so, as any technical cycle of reuse will still eventually end, thus resulting in building waste (Sassi, 2008). This is because, in contrast to the unending organic cycle, materials in a technical cycle need to constantly uphold their integrity to be suitable for reuse and cannot do this forever (BakerBrown, 2017). All materials degrade. Once a material in a technical cycle degrades it cannot be reused, whereas biodegradation for a material in an organic is desired for zero waste to occur (Sassi, 2008). Materials in an organic cycle are superior to those in a technical cycle regarding their ultimate waste reduction potential (Ganotopoulou, 2014).

This is in line with Auckland Council's waste reduction strategy (figure 5). Auckland Council's primary strategy is reduction which can be achieved by increasing the use of materials in an organic cycle that biodegrade and produce no waste (Auckland Council, 2019). Auckland Council's second strategy is reuse of building components which can be thought of as unlising materials in a technical cycle (Auckland Council, 2019)

Maximising the use of natural biodegradable materials in our buildings is the best approach to eliminating
Figure 5

Auckland Council's Waste Management Hierarchy

construction and demolition waste. Sassi, a leading scholar in the field of biodegradable building materials concluded in her study "Biodegradable Building" tha using biodegradable building materials, indeed, offers significant waste reduction potential and that there are significant opportunities to substitute non-biodegradable bulding materials for biodegradable alternatives (Sassi. 2006). Use of bioder biade beld ang materials in an organic cycle will, therefore, be sought primarily for the

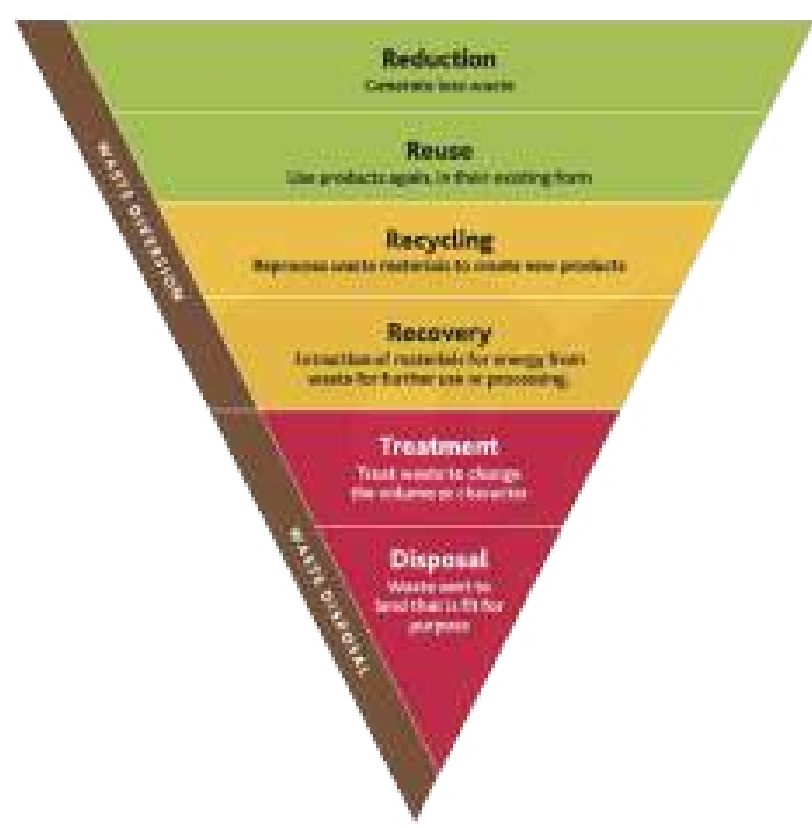

Reprinted From "Building Out Waste A guide for developers and building contractors" by Auckland Council, 2019, 2 (https.//www.makethemostofwaste.co.nz/media/534/ building-out-waste.pdf). Copyright 2019 by Auckland Council.

\section{Biodegradable and Reusable} components

Research suggests that constructing a building entirely out of biodegradable materials in an organic cycle is not realistic or achievable in today's mainstream construction industry (Sassi, 2006). Essential materials such as glass used for windows or concrete for foundations do not have suitable biodegradable alternatives (Sassi, 2006). In these cases, it would also be imprudent to swap these materials out for inferior biodegradable materials. Other difficult to overcome sources of non-biodegradable waste icult to metal fixings, second fix electrical goods (eg socket outlets, switches) and plumbing pipes (Sassi, 2006).

Building elements that have no biodegradable substitute should therefore be reusable and operate within a technical cycle to ensure zero waste. If designed to facilitate deconstruction all these non-biodegradable building elements can be reused. Wellington-based companies such as the Building Recyclers, №.8 Building Recyclers and Rummagers specialise in the reuse of building elements such as windows, doors, plumbing pipes, bathroom vanities, metal fixings, socket outlets, switches and many other building components. In addition, research into reusable prefabricated lightweight concrete foundations has been undertaken and deemed plausible (Llorens Duran \& Pujadas Gispert, 2015).

Therefore, achieving a zero-waste medium density housing design is theoretically possible. Indeed, research suggests that a combination of biodegradable materials and reusable components is a realistic approach to achieving a closed material loop and zero waste (Sassi, 2006).

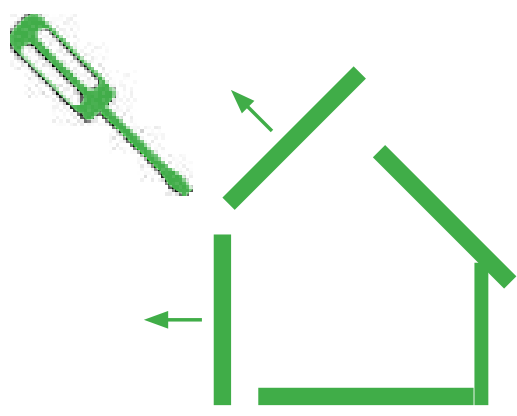

3. Deconstruction Not Demolition

However, with this approach, to ensure zero waste at the end of the building's life, demolition is not an option. For a $100 \%$ biodegradable building, demolition would be acceptable as alt the material could be left to decompose leaving no waste. But when any non-biodegradable components are present, such as glass windows, concrete foundations or other non-biodegradable building elements mentioned above, overall biodegradability is compromised, and the bullding cannot be demolished and left to decompose. Therefore, deconstruction of building elements is required to allow the reuse of the inorganic components. Deconstruction is also recognised as part of the waste reduction strategy in the BREEAM building label assessment where it is rewarded over demolition. Because of the necessity of deconstruction, there lies an opportunity to reuse the organic components also. Deconstruction also allows for any biodegradable elements with compromised integrity to be separated for decomposition. A building must be designed to enable deconstruction. Building elements should be mechanically fixed, preferably with few fixings and easily accessible 


\subsection{Objectives}

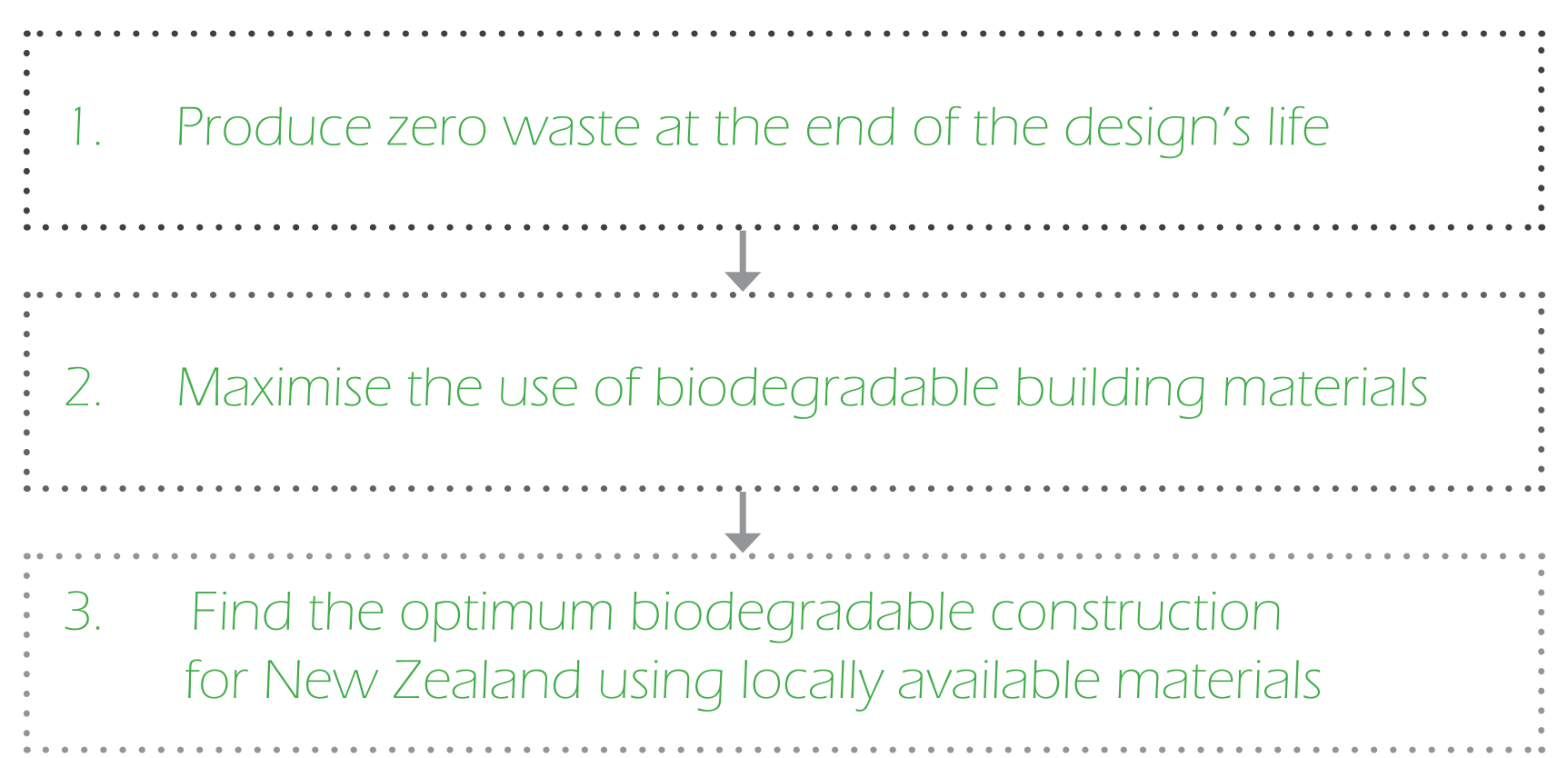

\subsection{Research Question}

How can a medium density housing scale project be built best in New Zealand using predominantly biodegradable materials?

\subsection{Hypothesis}

A dwelling construction can be made entirely zero waste using biodegradable and reusable components. This hypothesis is shared with Sassi from her paper "biodegradable building" in 2006. 


\subsection{Relevance/Scope}

\section{Medium Density Housing}

The architectural design output for this thesis is a medium density housing (MDH) development because:

1. Although many vernacular architectural typologies such as earth or thatch huts are entirely zero-waste and biodegradable, they are no longer the optimum living environments. MDH offers a housing typology suitable for the modern day

2. The density of housing in New Zealand needs to increase. This is driven by the increase in population and demand for housing within a finite landscape. An estimated $30 \%$ of the total of all new dwellings in Auckland $(35,000$ houses) have been built in intensified typologies in the last decade (Syme, 2005). Wellington has also seen considerable intensification through both downtown apartment development and suburban inith recent years (Bryson \& Allon, 2O Ne Because MDH is a relatively new design typology for New Zealand and the e rescom this thesis to this design typology is

3. The MDH scale of 1-3 storey multi-unit dwellings provides the optimum scale and application for biodegradable building materials to be tested.

4. Medium Density Housing has also improved the environmental sustainability of our country's housing f land infrastructure and energy (transport) (Witten et al., 2011).

\section{Figure 4}

Medium Density Housing diagram
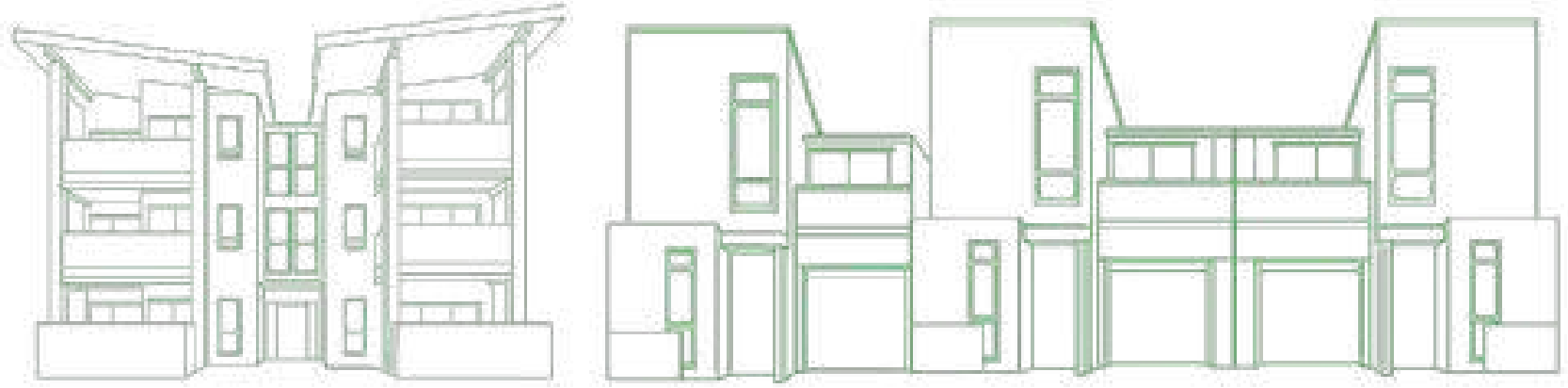

Adapted from "Attitudes towards MDH" by BRANZ, 2017, RIBA Publishing, p. 1. Copyright 2017 by BRANZ

\section{Engagement With Tikanga Māori} construction industry aligns with tikanga Māori, and taonga tuku iho (heritage) (Environmental Choice New Zealand, 2020

Before the arrival of the settlers, the vernacular architecture of Māori was entirely zero-waste and biodegradable. This thesis is striving to restore New Zealand architecture to roots.

\section{Additional Benefits of Bio-sphere}

\section{Materials}

Bio-sphere materials not only reduce end-of-life waste but they reduce consumption of finite resources, energy consumption and greenhouse gas emissions. These areas co buildings. However the operation energy of a building also has the potentiat the lowered by biodegradable insulation materials such as straw, wool or hemp.
The aspiration to achieve zero waste for the New Zealand the tradition of katitiakitanga to sustain and restore our collective resources to enhance the mauri (life force) of is still to be done in the area of the embodied energy of

\subsection{Methodology}

\section{Methodological Process}

1. This thesis begins with a precedent and literature review of biodegradable materials and construction techniques globally and in NZ. This is for the purpose of compiling a comprehensive list contemporary and vernacular materials and techniques.

2. It is from this list that the most suitable biodegradable building materials for New Zealand are determined. The most suitable biodegradable material is selected for the building elements of structure, insulation, cladding. foundations, flooring and roofing, as each element has unique performance requirements. Materials are selected based on availability and performance regarding the specific requirements for each building element.

3. The most suitable biodegradable building materials selected in the last step are used in this step to explore construction methods to find the most suitable approach for the materials. The construction approaches of $\mathrm{In}$ situ construction, standardised block modules and prefabricated wall panels are then explored and reviewed. Wall build-up design proposals are produced for each construction approach and then the approaches are reviewed. The constructic regarding how successful the approach has been in increasing the uptake of biodegradable materials, reuse potential and closeness to conventional New Zealand construction practice.

The final construction of the design is not designed at this stage but rather the construction approach decided. This is because a construction approach cannot be finalised before the design as the two aspects are inherently linked.

4. Once a construction approach is decided a building form is pursued that supports the use of biodegradable materials. The building form is mainly driven by the need to protect the biodegradable insulation materials from moisture infiltration. In this section, a suitable MDH design is also pursued based on MDH design typology research.

5. The design is then integrated onto a site in Upper Hutt. Although a sited design does not contribute to the thesis
objectives, architectural design is never produced in isolation to its site. A sited design is used to demonstrate the potential for biodegradable building materials to be applied in an urban context as MDH development. In addition, a sited design is pursued because the selected architectural typology of Medium Density Housing requires careful consideration of the site and inter-unit relationships. However, a site development design is not pursued beyond the point of architectural sufficiency as the site development design merely architecturally justifies the building design. The building design is used 列 are pursued.

6. Once the architectural design of the MDH buildin has been resolved and integrated on site the building's construction can be designed in detall. A detailed BIM model of the design is produced to extract accurate volumes of the buitding components. The same is done for an identical design using conventional New Zealan materials and construction techniques. This is done to allow comparison

7. The building components are then categorised regardin their biodegradability or reusability or lack thereof for bo designs. This is done so that the proportion of waste an biodegradable materials can be generated and compared. Results regarding whether the design achieved zero wast through the use of biodegradable and reusable buildin components are presented. Frthermore, the degree biodegradability of the overall construction is presented.

8. Final conclusions are then made as to whether the thesis objectives were achieved. Whether or not Aucklan Council's waste reduction targets can be met is also addressed. Finally, further research opportunities are also presented. 


\section{Methodology Diagram}

\section{$1 \quad$ Literature Review (chapter 2)}

2 Find Most Suitable Biodegradable Building Materials for NZ (chapter 3)

3 Construction Approach Exploration (chapter 4)

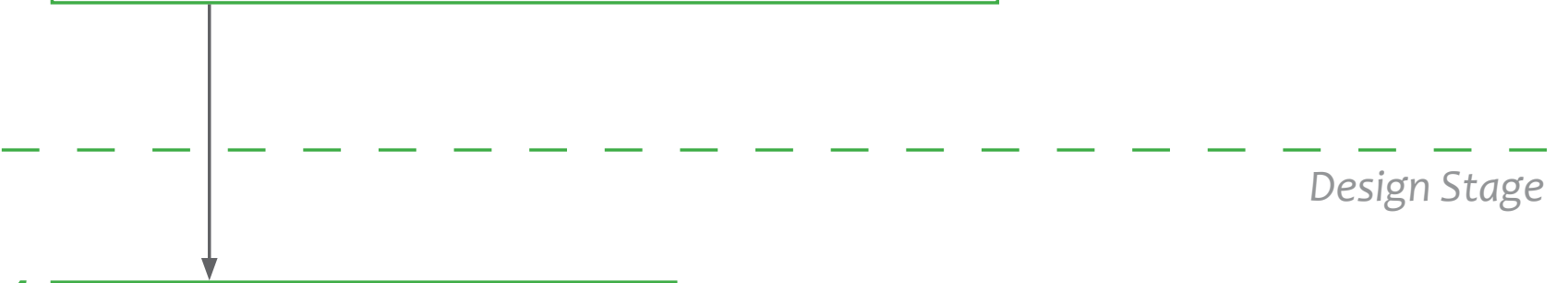

4 Form Exploration (chapter 5)

5 Site Integration (chapter 6)

6 Detailed Design (chapter 7)

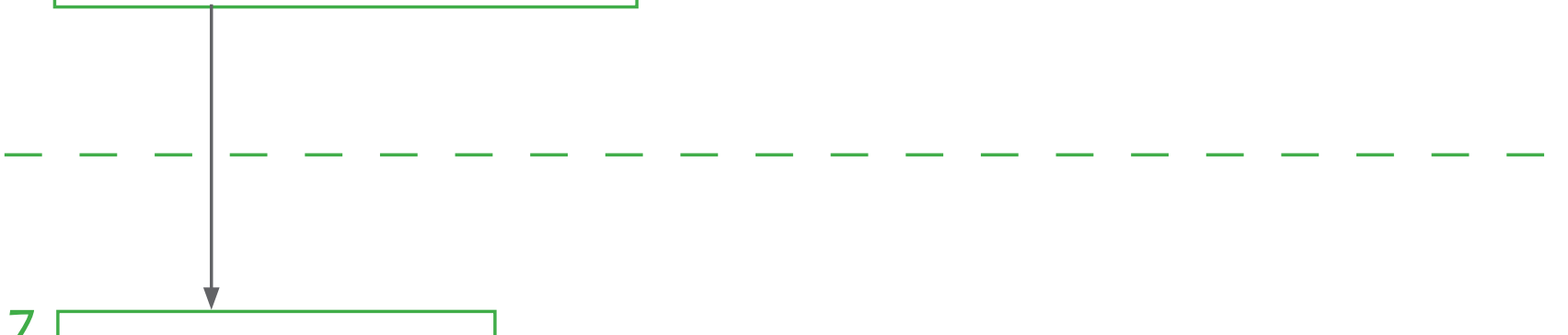

\section{Objective Assessment Approach}

\begin{tabular}{|c|c|c|c|}
\hline Thesis Objective & Assessment Criteria & Metric & Criteria Objective \\
\hline 1. Zero Waste & $\begin{array}{l}\text { Proportion of waste diverted } \\
\text { from land fill }\end{array}$ & $\%$ by volume & 100\% Waste Diversion \\
\hline $\begin{array}{l}\text { 2. Maximise } \\
\text { Biodegradable Materials }\end{array}$ & $\begin{array}{l}\text { Proportion of biodegradable } \\
\text { materials }\end{array}$ & $\%$ by volume & $\begin{array}{l}\text { As close to } 100 \% \text { as } \\
\text { possible }\end{array}$ \\
\hline \multirow[t]{7}{*}{$\begin{array}{l}\text { 3. Find Optimum } \\
\text { Biodegradable } \\
\text { Construction Approach for } \\
\text { New Zealand }\end{array}$} & Availability of Materials & $\begin{array}{l}\text { High=Produced in NZ } \\
\text { Moderate = Raw materials } \\
\text { available in NZ } \\
\text { Low=Imported product }\end{array}$ & As high as possible \\
\hline & \multirow[t]{3}{*}{$\begin{array}{l}\text { Performance of construction } \\
\text { in New Zealand's climate }\end{array}$} & $\begin{array}{l}\text { Qualitative assessment of } \\
\text { durability }\end{array}$ & As high as possible \\
\hline & & Thermal Resistance $\left(\mathrm{m}^{2} \mathrm{~K} / \mathrm{W}\right)$ & As high as possible \\
\hline & & Vapour Resistance (MNs/g) & $\begin{array}{l}\text { Informs vapour } \\
\text { management }\end{array}$ \\
\hline & \multirow{3}{*}{$\begin{array}{l}\text { Suitability of construction } \\
\text { approach (In-situ, } \\
\text { standardised block modules, } \\
\text { prefabricated panels) }\end{array}$} & \multicolumn{2}{|c|}{$\begin{array}{l}\text { Most successful strategy in increasing } \\
\text { the uptake of biodegradable } \\
\text { materials }\end{array}$} \\
\hline & & \multicolumn{2}{|l|}{ Greatest reuse potential } \\
\hline & & \multicolumn{2}{|c|}{ Closest to mainstream NZ construction practice } \\
\hline
\end{tabular}

In order to assess against the objectives of this thesis, measurable assessment criteria had to be developed. For the irst two thesis objectives, existing metrics could be relied upon, but for the hird hesis objeclive, original qualitative measures had to be developed. The first hesis objeclive uses the mith of by BREEAM the Declare abel and The tiving Bulding by BREEAM, the Declare label and The Living Bulding challenge th its mortion of biodegradabe or conpostas mecteris by by the Living Building Challeng and the Delare labe The criteria the to assess the third thesis objective are the

availability and performance of materials in addition to the suitability of the construction approach for the material

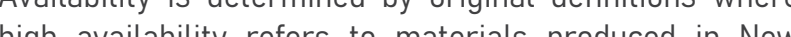
high avalabilty refers to materials produced in New Zealand, moderate avalabiny refers to raw materials the re avallable in New Zealand and low avalabily refers to mported materiats. Pertord ance is assessed qualt atively regarding drabily and is assessed qualitatively regarding its ability to increase the uptake of biod and closeness to mainstream New Zealand construction

7 Results (chapter 7)

\section{Conclusions}




\section{Literature Review}

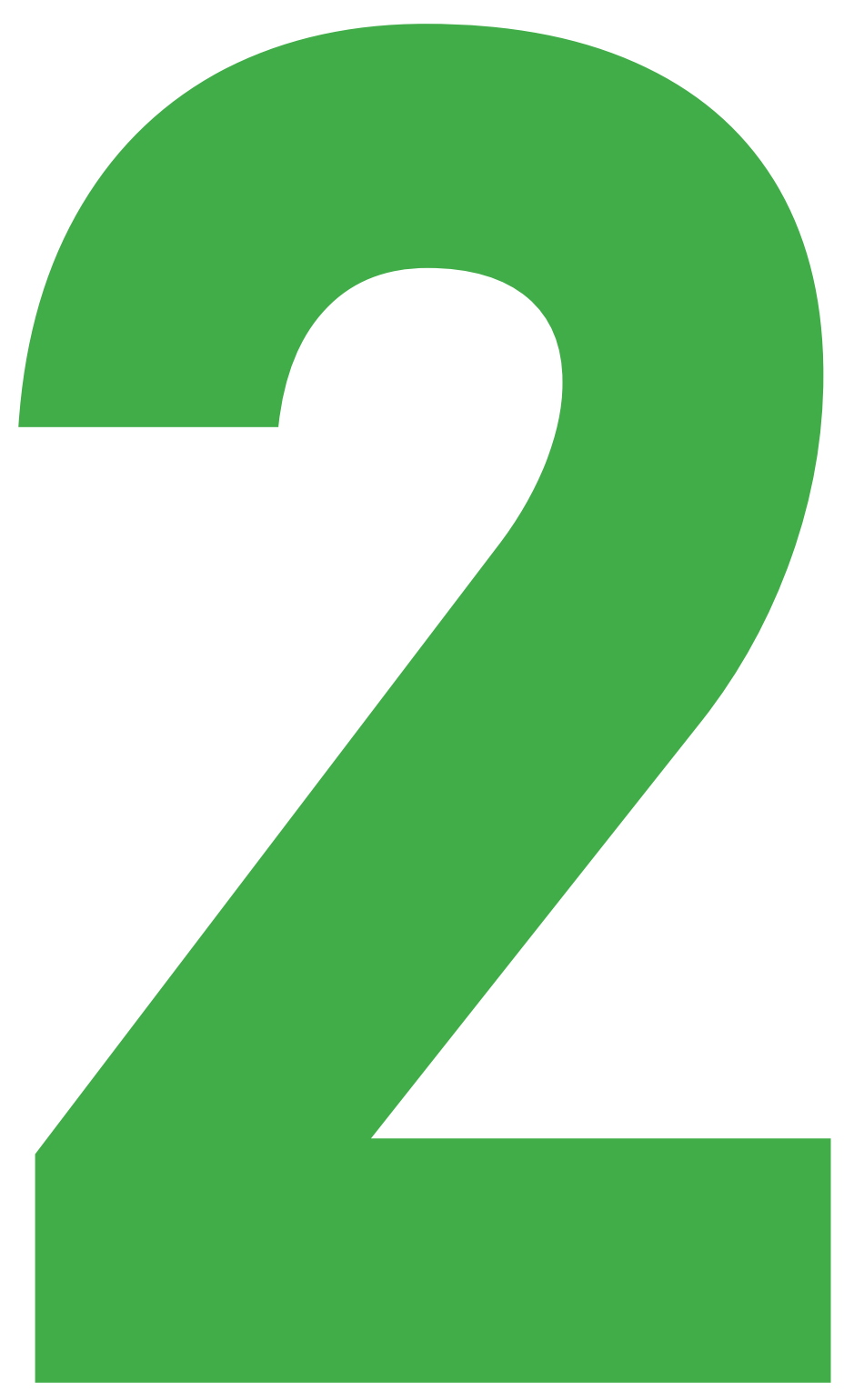

\section{Chapter Outline}

The purpose of this literature review is to compile a list of vernacular and contemporary biodegradable materials globally and in New Zealand. Innovative international vernacular and contemporany precedents were briefty reviewed before New Zealand's biodegradable materials and construction techniques were reviewed more thooughly. In the revew of international precedents, he broject is extrated and is hightighted green in its the project is extracted and is highlighted green in its titte. collected to gain an understending of what materias have

\subsection{Biodegradable Vernacular Architecture}

In this section, international biodegradable vernacular precedents are reviewed. Vernacular architecture presents some of the most creative and effective examples of how humanity constructed with biodegradable materials in the past. Precedents were selected that used a biodegradable material in a manner that would seem innovative or unconventional through a modern lens. The review of vernacular precedents was not exhaustive but only the

Figure 6

most innovative uses of material were selected because the review of New Zealand's biodegradable materials and techniques presented later in the chapter was the main focus. These vernacular buildings still dominate in many places in the world. It is estimated that between 30 and 50 percent of the world's population live in buildings constructed of earth (Rael, 2009).

Figure 7

Goahti Sod Houses, Arctic Region

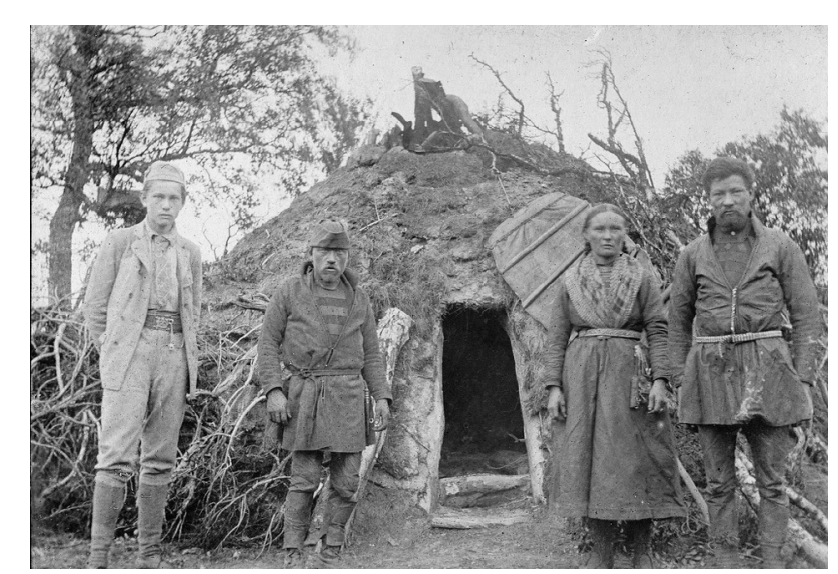

Figure 8

Ma'dan Reed Houses, Iraq

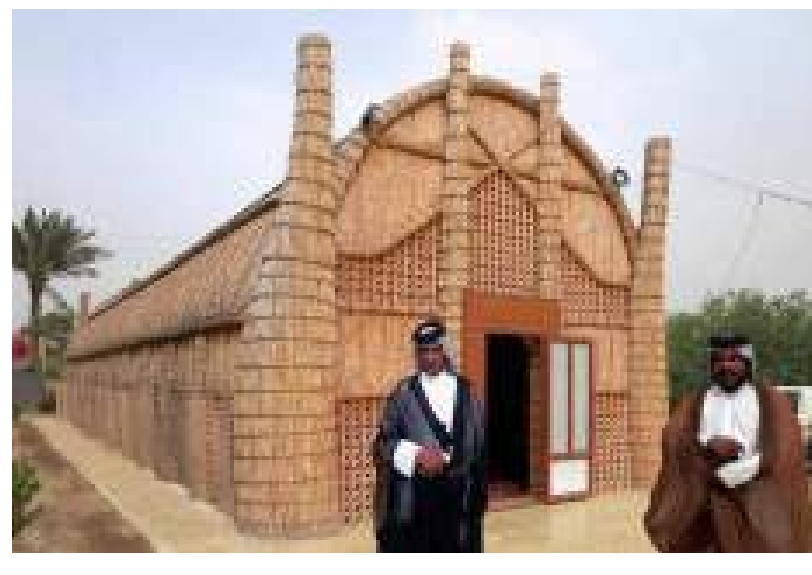

Note. Reeds are wrapped in bundles and used to create columns, arches and walls. A reed house can be erected in just 3 days and can last up to 25 years with proper care.

Seaweed Roofed Houses on Læso, Denmark

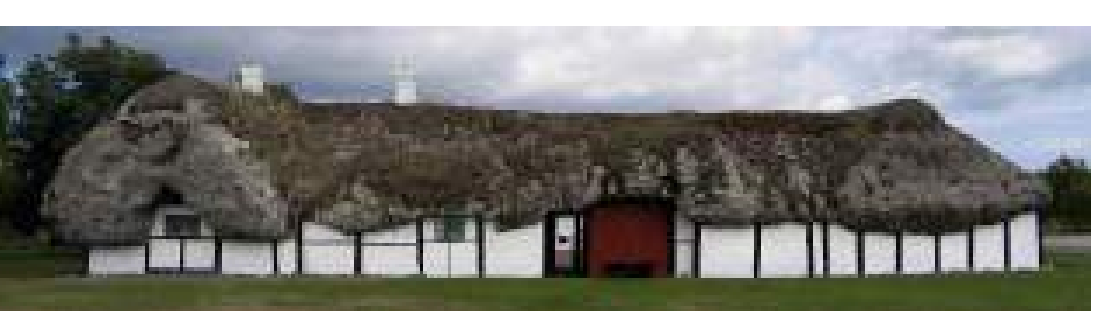

Figures retrieved from Archdaily viltps./Www.archdaily.com/805415/11-

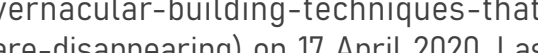
are disappearing) on 17 Aprit 20

House with seaweed roof made using eelgrass from the ocean that is able to withstand decay for hundreds of years, thanks to the fact that they are impregnated with saltwater. 300 kilograms of eelgrass is required for every 1 square meter of roofing. 
Clay-plaster huts, Cliff of Bandiagara, Mali

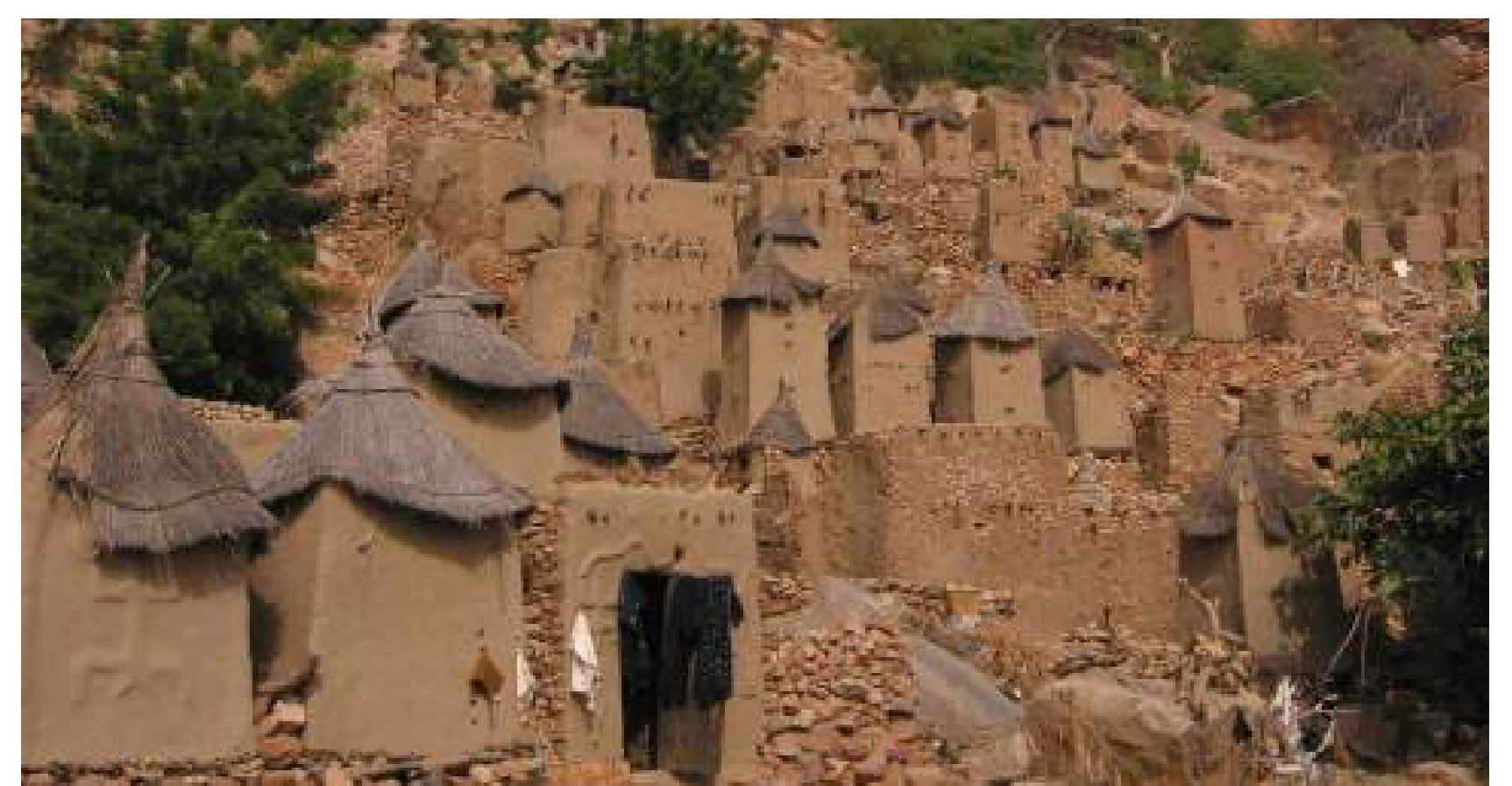

Note. Also known as the Land of the Dogons, 289 villages of earthen buildings cover sandstone plateaus, escarpments Note. Also known as the Land of the Dogons, 289 villages of earthen buildings cover sandstone plateaus, escarpments

Retrieved from Archdaily (https://www.archdaily.com/805415/11-vernacular-building-techniques-that-are-disappearing) on 17 April 2020. Last updated in 2017.

Figure 10

Adobe Brick, Beehive Houses of Harran, Turkey

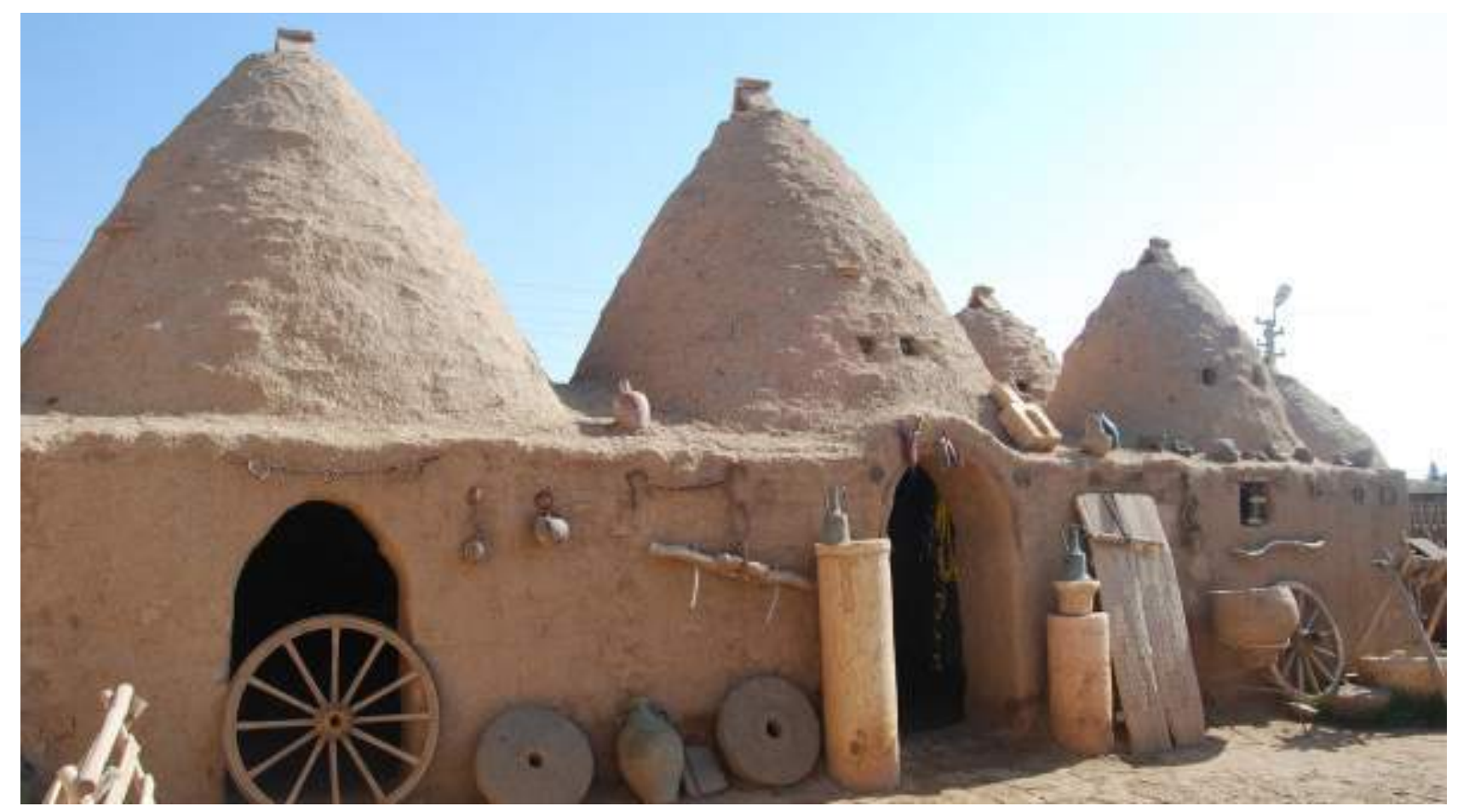

Retrieved from Turkish travel blog (https://turkishtravelblog.com/the-beehive-houses-of-harran-turkey/) on 17 April 202
Cob, old granary in Nalut, Libya

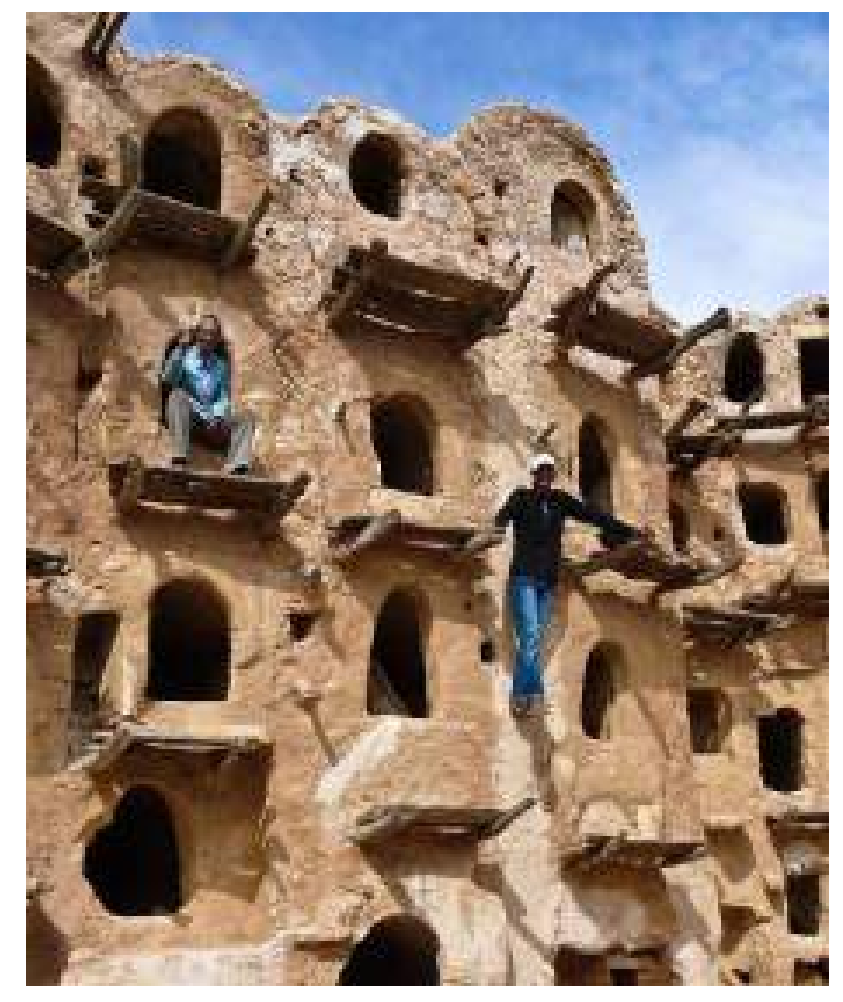

Retrieved from Atlas of wonders (https://www. atlasofwonders.com/2011/04/libya-heritage-in-danger. html) on 17 April 2020

Figure 13

Rammed Earth, the great Mosque of Djenné, Mali, West Africa

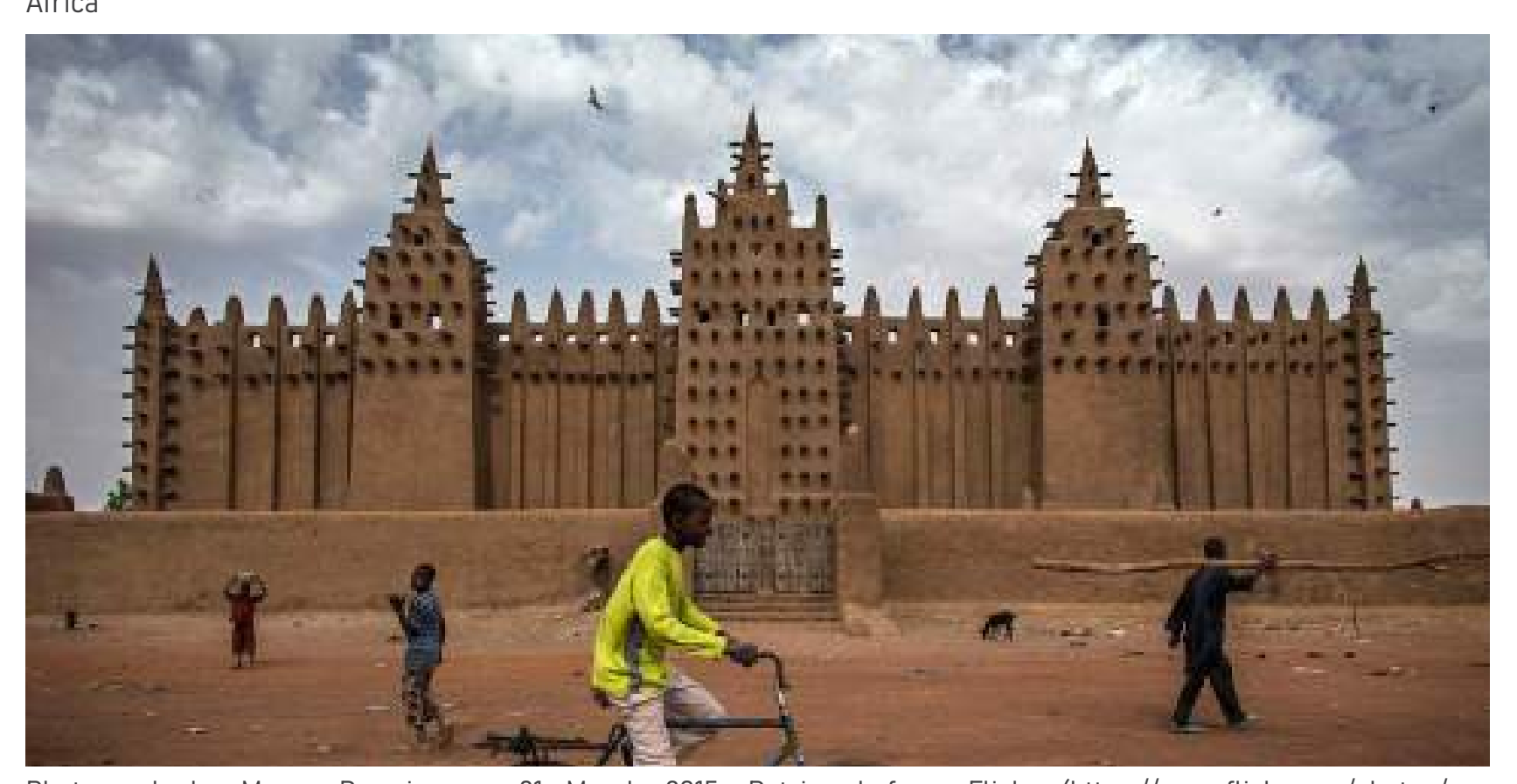

Photograph by Marco Dormin
Wattle and Daub, Mugsum Mud Huts, Cameroon

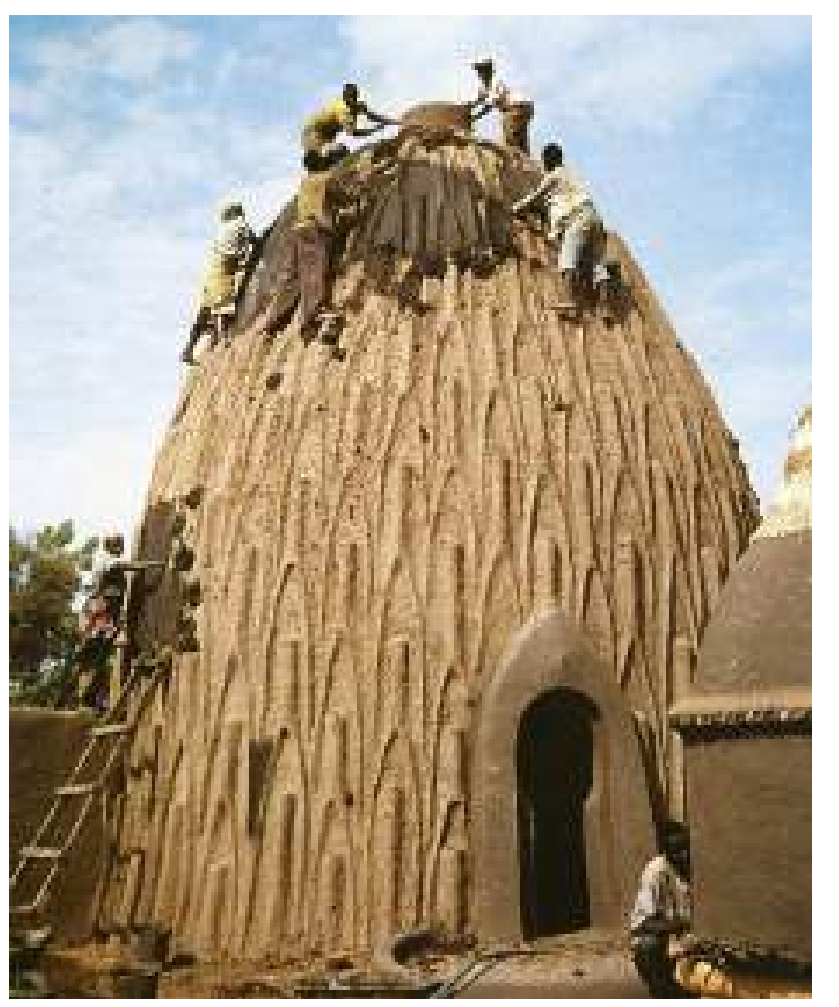

Note. Geometrically arranged reeds are covered in mud to form of a catenary arch, withstanding the maximum load with minimum material. The 9-meter-tall dwellings have practical footholds that also contribute to their aesthetic Retrieved from Design boom (https://www.designboom com/architecture/musgum-earth-architecture/) on April 2020. produce the domestic mud huts. The huts are built in the 


\subsection{Biodegradable Contemporary Architecture}

In this section, international contemporary precedents that were deemed innovative in their production or are reviewed. Although technological advances can be construction of biodegradable materials. similarly, to the blamed for en Al bioderadalso produs. Precedents were selected in its title.

Figure 14

Cork House, Eton, Berkshire, UK

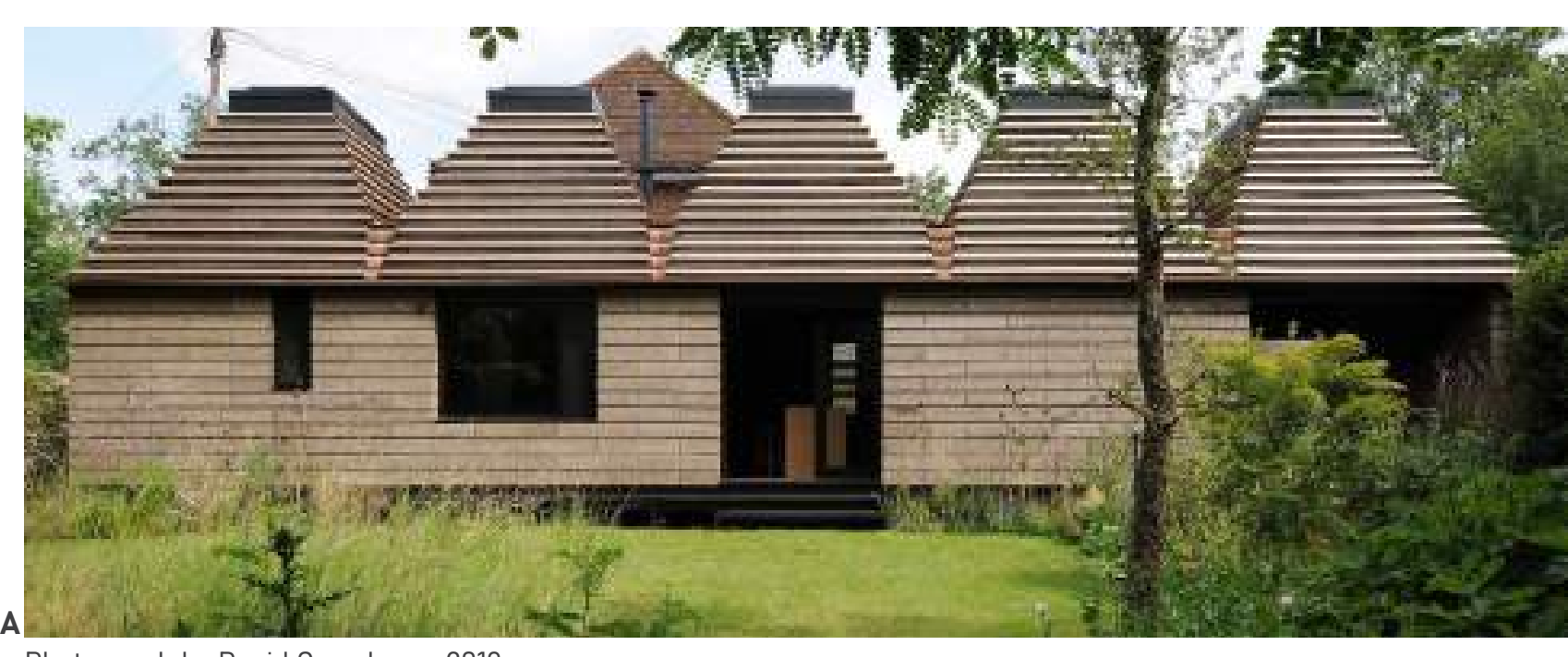

Photograph by David Grandorge, 2019.

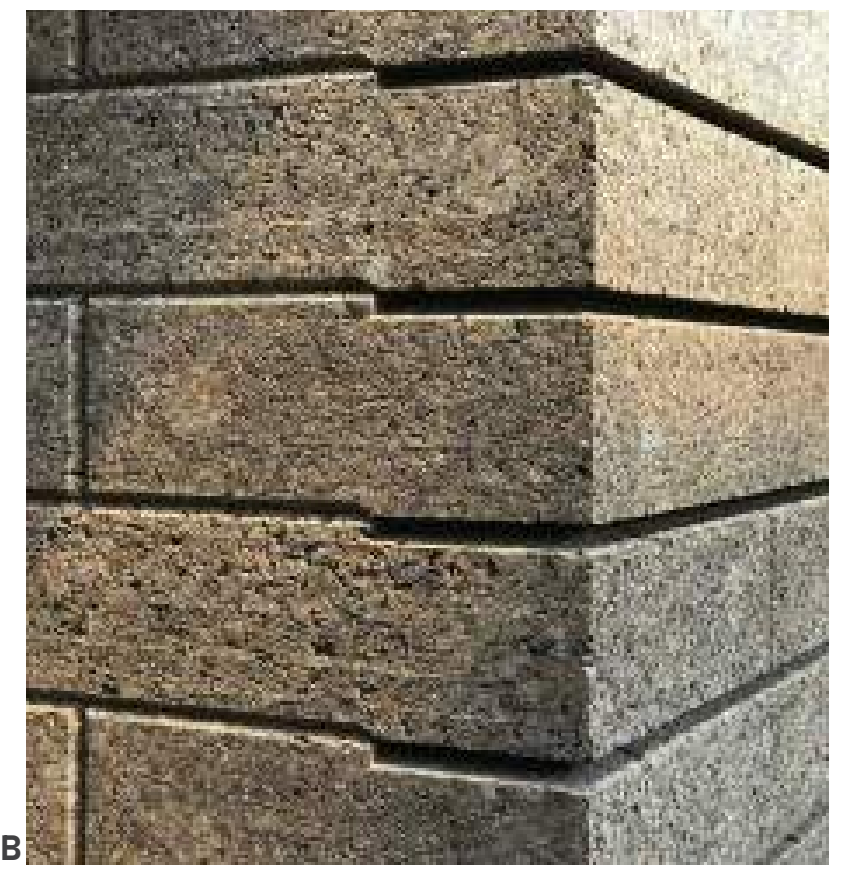

This house was designed by Matthew Barnett Howland with Dido Milne and Oliver Wilton. The design was constructed in 2019 and was a contender for the 2019 Stirling Prize. The house is nearly entirely constructed out of the bioder The hous consists of 1268 interlocking cork blocks tha The house consists of 1,268 interlocking cork blocks that do entrely without non-biodegradable glue or mortar. hese blocks can be deconstructed at the end of to biodegrade in an organic cycle.

The cork oak was brought to New Zealand by the early settlers with the earliest recorded tree planted in Symonds St, Auckland in 1855 by Dr Andrew Sinclair (Macarthur, 1994). The tree is well suited to New Zealand climates (Isaacs, 2015). Although the commercia production of cork did not develop, the cork oak can still be found in many parts of New Zealand (Macarthur, 1994).
Figure 15

Wood and Straw Thatch House, Kumrovec, Croatia
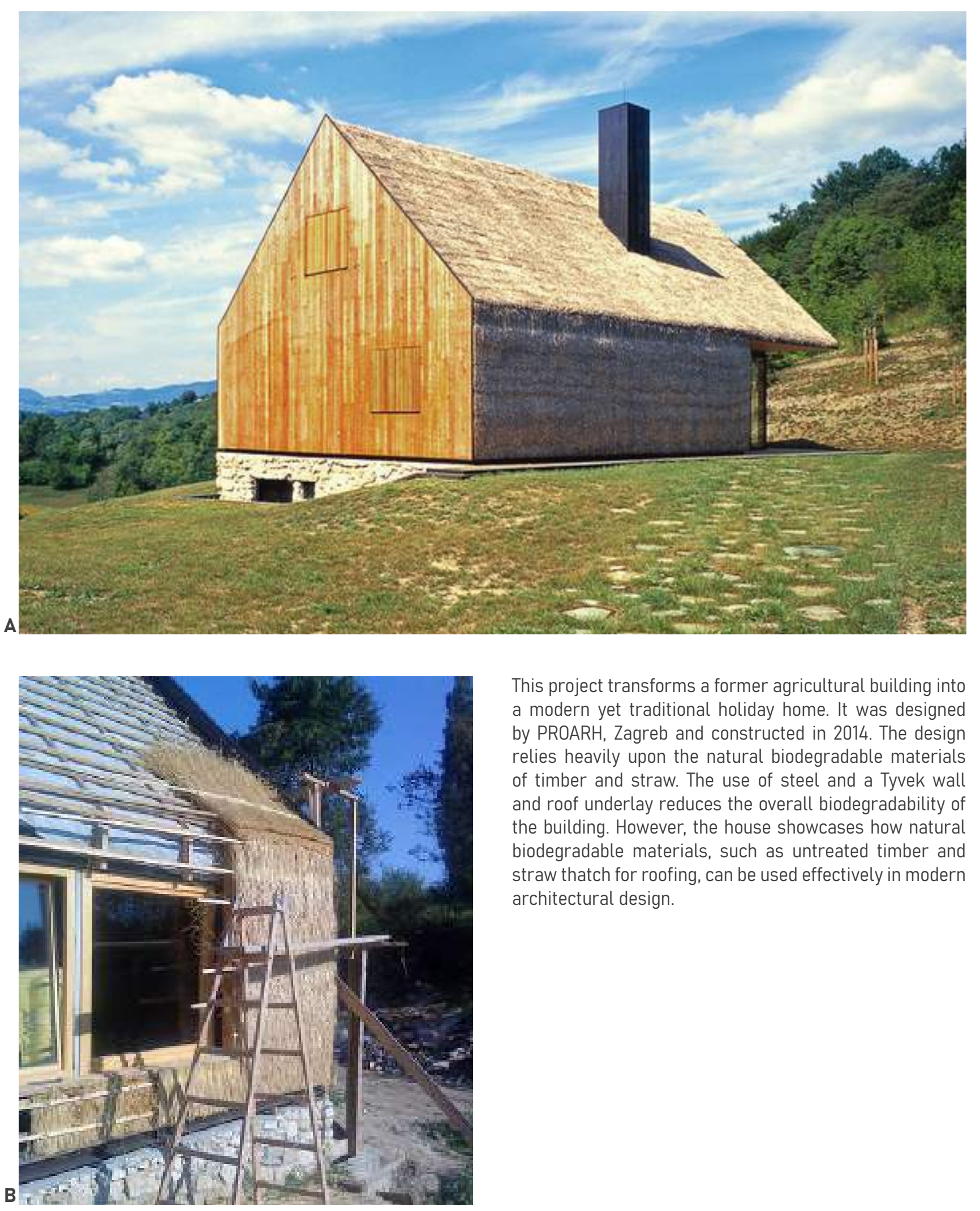

This project transforms a former agricultural building into a modern yet traditional holiday home. It was designed by PROARH, Zagreb and constructed in 2014. The design relies heavily upon the natural biodegradable materials of timber and straw. The use of steel and a Tyvek wall and roof underlay reduces the overall biodegradability of the building. However, the house showcases how natura biodegradable materials, such as untreated timber and straw thatch for roofing, can be used effectively in modern architectural design

Photograph by Alex de Rijke, 2019. Retrieved from Detail (https://www.detail.de/blog-artikel/ein-materialfuenf-pyramiden-cork-house-von-matthew-barnetthowland-34518/) on 17 April 2020. Last updated 19 Augus 2019

Photographs by Damir Fabijanic, 2014. Retrieved from Detail (https://www.detail.de/artikel/lokales-erbeferienhaus-in-kroatien-11897/) on 17 April 2020. Last updated 11 May 2014. 


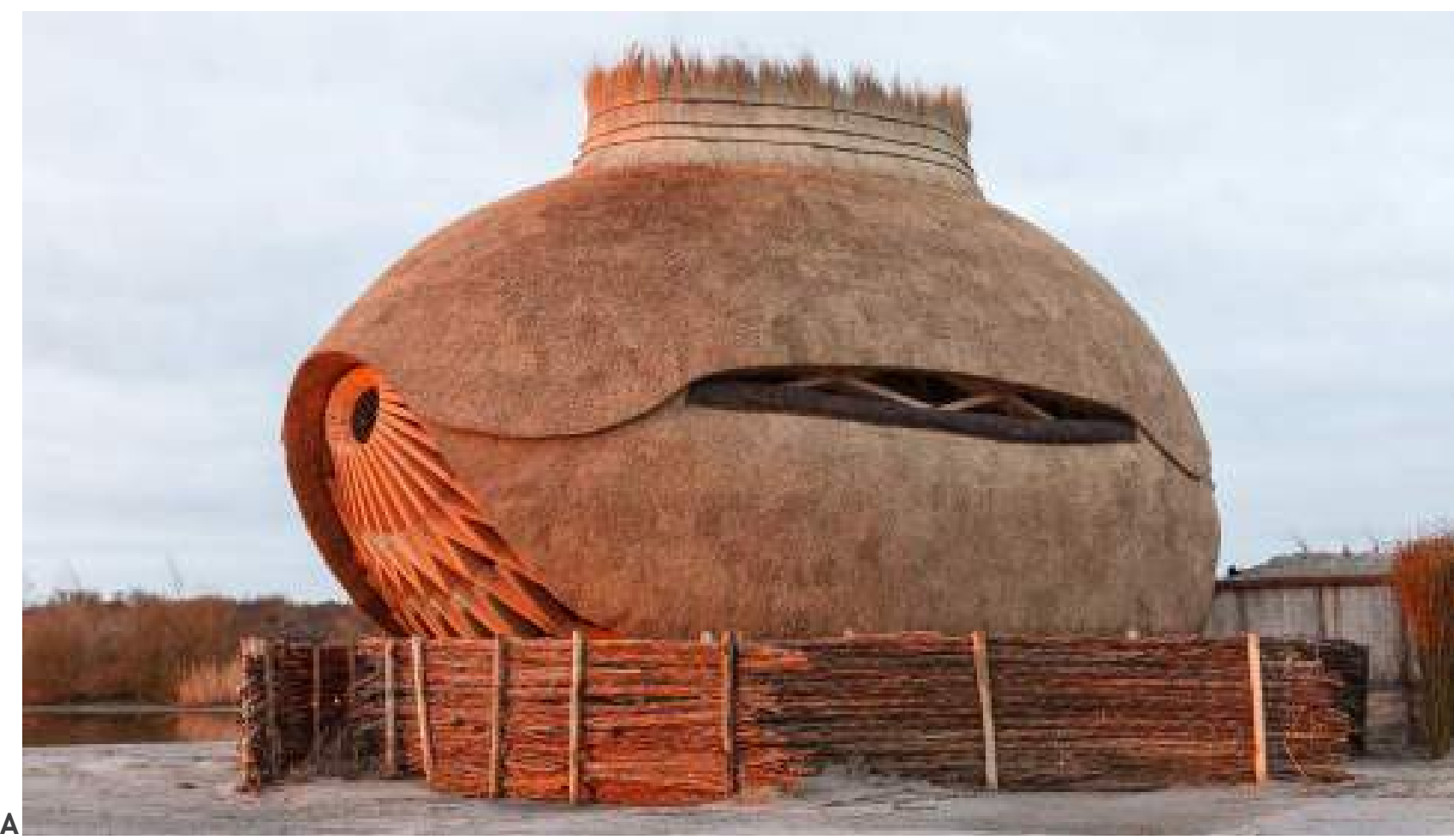

Photograph by Katja Effting, 2019.

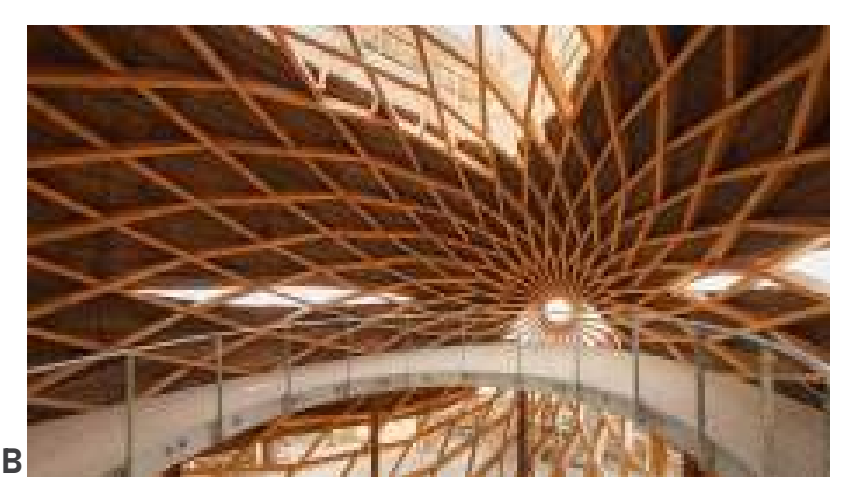

This bird hide was designed by RAU Architecten, RO\&AD Architecten and was constructed in 2019. It is located on the Scheelhoek nature reserve and uses a natural material pallet of stone, untreated wood and native reeds. The timber structure is made up of 402 prefabricated elements that can be dismantled at the end of life to either be reused in a technical cycle or left to biodegrade in a organic cycle

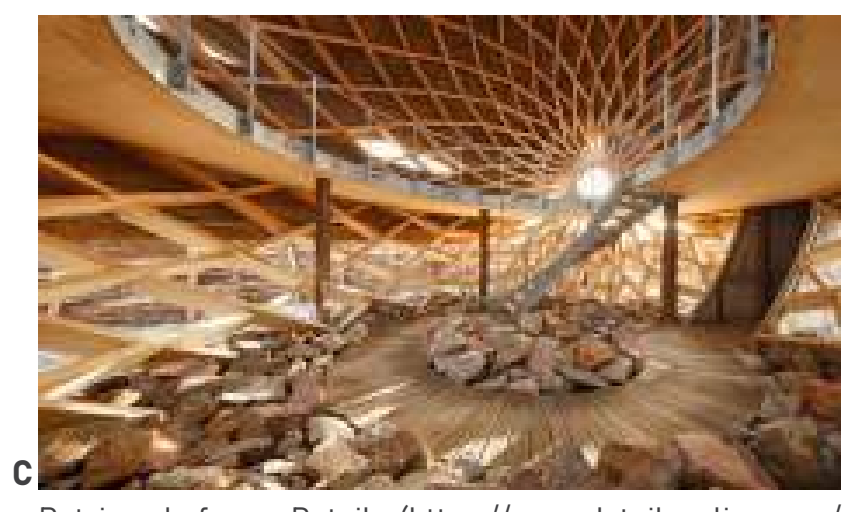

Retrieved from Detail (https://www.detail-online.com/ en/article/a-beached-ovoid-tij-bird-hide-by-roadarchitecten-34846/) on 17 April 2020. Last updated 30 October 2019
Figure 17

Clay Gaia House, Massa Lombardo, Italy
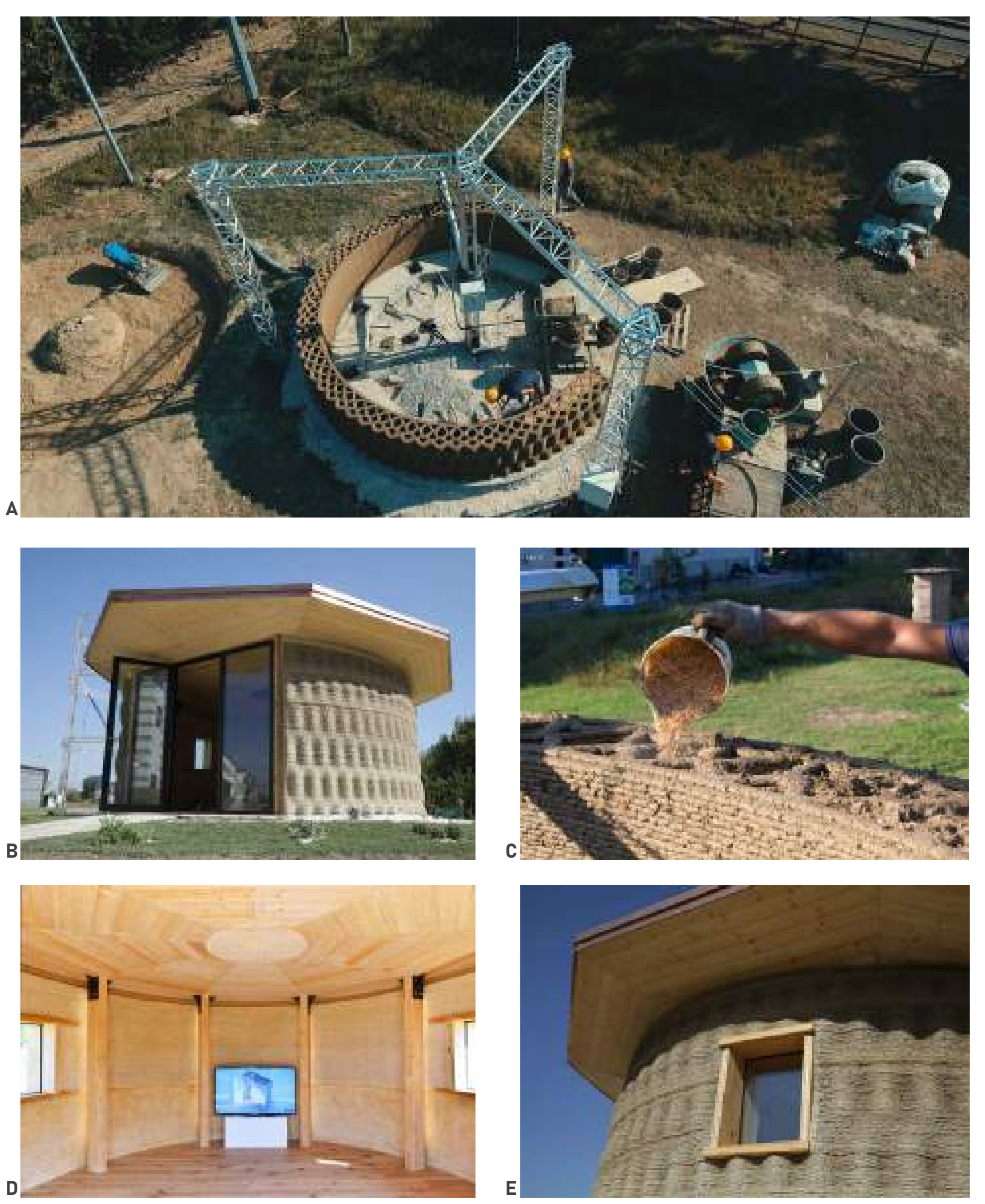

Note. The Gaia House, built in October 2018, has a 3D-printed outer shell made from a mixture of soil and other biodegradable materials such as chopped rice husks. The house is $30 \mathrm{~m} 2$ and uses timber columns as structure to hold up the timber roof.10/2018

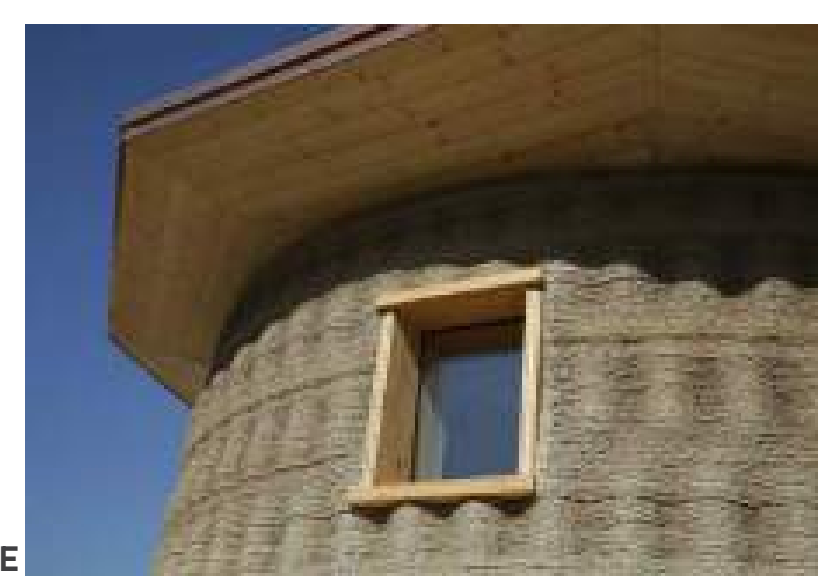

Figures retrieved from Dezeen (https://www.dezeen. com/2019/02/27/gaia-wasp-3d-printed-houseFebruary 2019 biodegradable-video/) on 17 April 2020. Last updated on 
3D-printed clay housing Concept, 2019 research project from the Institute for Advanced Architecture of Catalonia (IAAC)

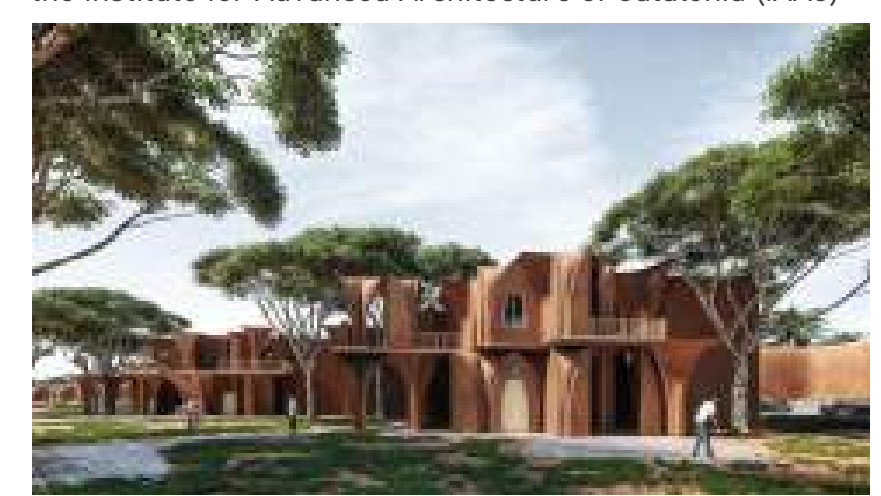

Retrieved from IAAC (https://iaac.net//project/buildingarchitecture-continuity/) on 17 April 2020

\section{Figure 20}

3D-printed clay housing Concept, 2017-2018 research project from the Institute for Advanced Architecture of Catalonia (IAAC)

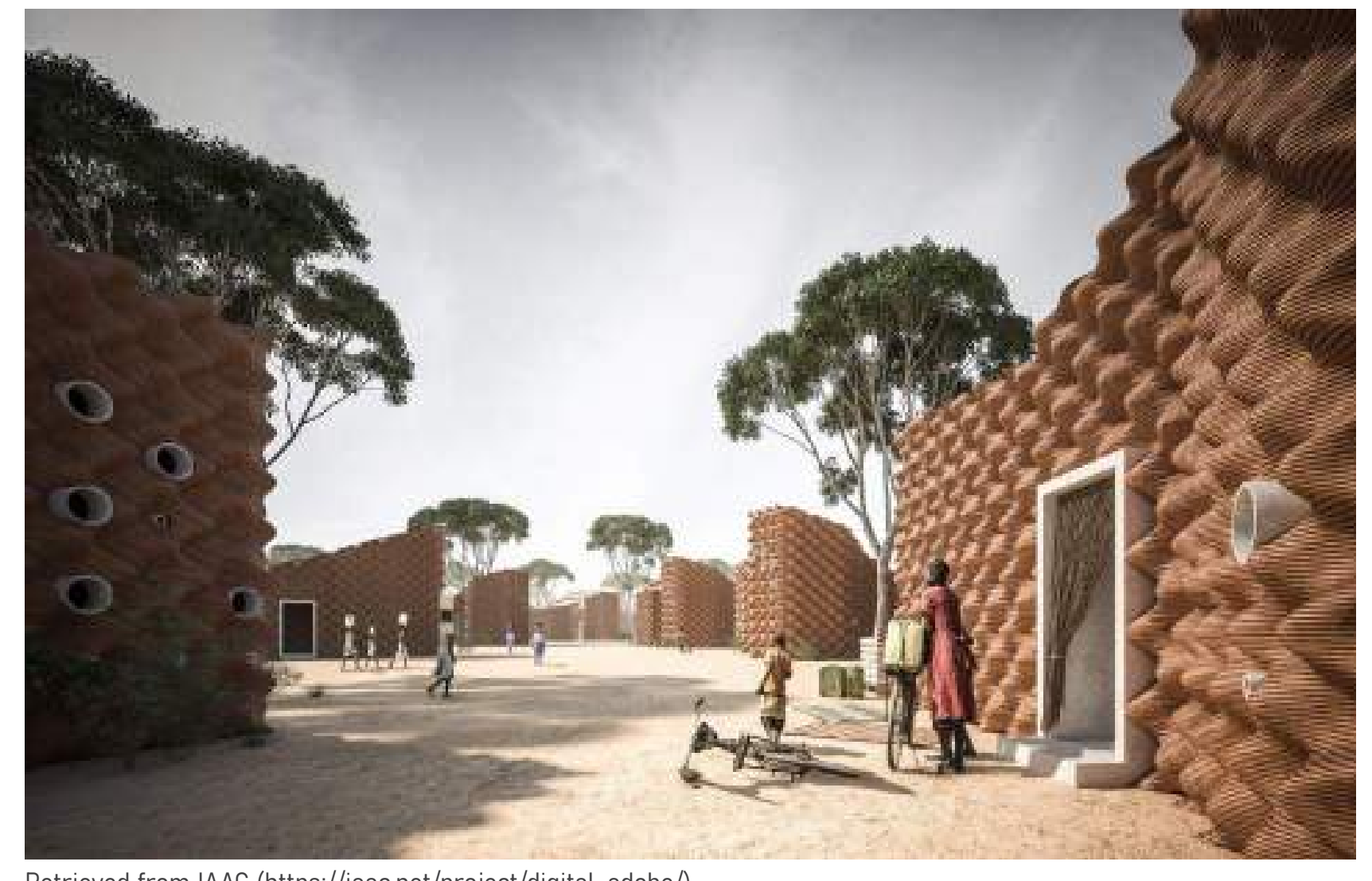

Retrieved from IAAC (https://iaac.net/project/digital-adobe/) on 17 April 2020

In the last 3 years there has been significant research into the potential of $3 \mathrm{D}$ printing biodegradable houses out of clay 28
TECLA Clay project, Designed by Mario Cucinella Architects (MCA) and engineered by WASP

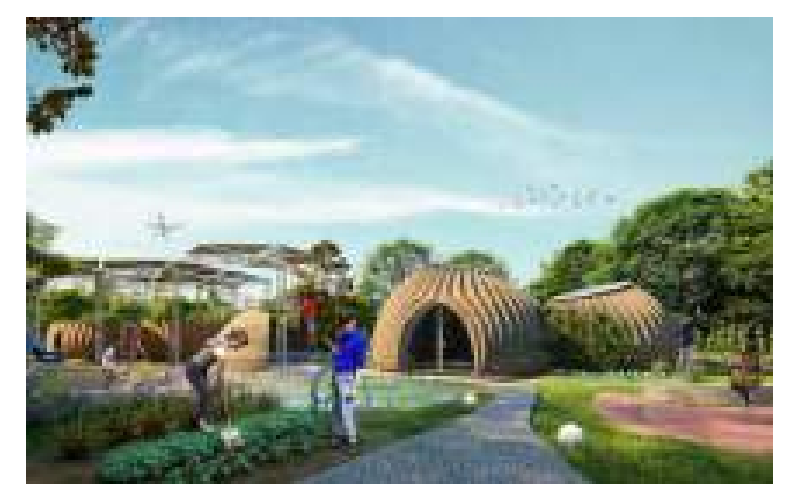

Note. The first prototype was built in 2019 near Bologna in Italy. TECLA will be the first house to be entirely $3 \mathrm{D}$ printed using locally sourced clay. The houses will be waste. Waste.

Retrieved from MCA (https://www.mcarchitects.it/ mario-cucinella-architects-and-wasp-start-on-sitefor-susta-abletype-3d-printed-global-habitat23 October 2019 coming design
Figure 21

Hy-fi, a temporary outdoor pavilion constructed out of Mycelium blocks by New York based practice, The Living.

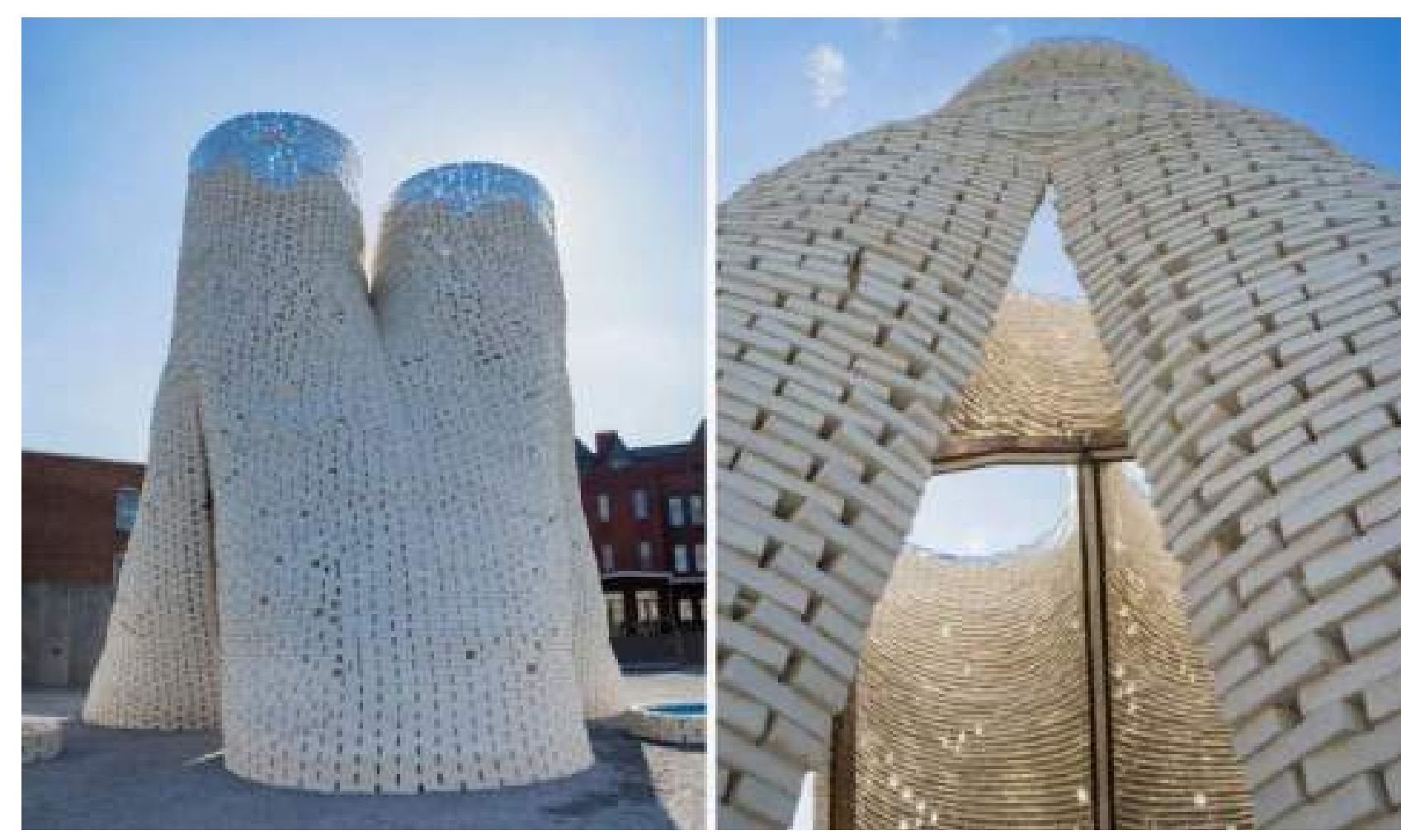

Photographs of Hy-fi were taken by photo by kris graves. Retrieved from Design boom ( https://www.designboom.com/ architecture/hy-fi-the-living-david-benjamin-moma-ps1-young-architects-program-2014-07-01-2014/) on 15 April 2020. Last updated 1 July 2014

\section{Figure 22}

Tiny House, built in 2013, in New York by Ecovative uses mycelium as insulation
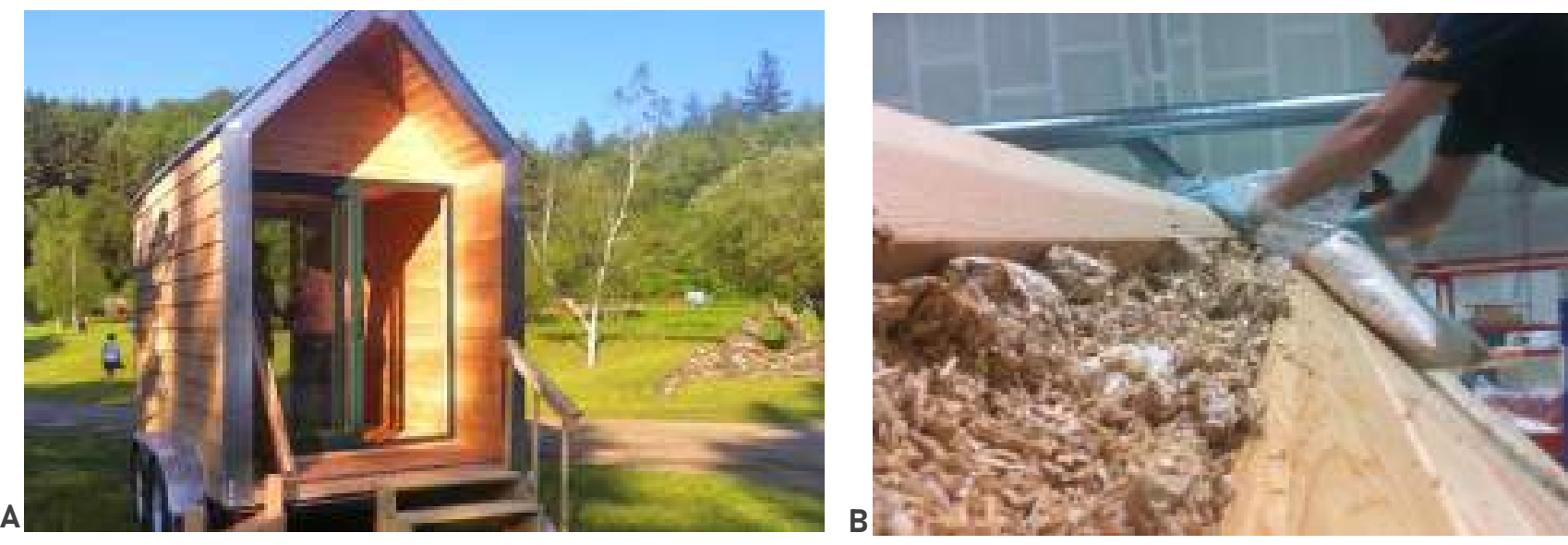

19 April 2020. Last updated 17 September 2014

Mycelium can be thought of as the roots of a fungus. When combined with agricultural by-products like corn stalks, the mycelium grows and when it is all compressed and dehydrated an incredible material is produced. This material is more insulative than fiberglass insulation, it is fireproof, non-toxic, partly mould and water-resistant and stronger per kilogram than concrete. Mycelium

as a building material is $100 \%$ biodegradable and can in any form that a mould can be made for. Mycelium offers incredible potential to the building industry, however, at the moment it has only be used to create a temporary outdoor pavition (figure 21) and for of prototypes built. 
Mud Shell, by MuDD Architects, London, 2018

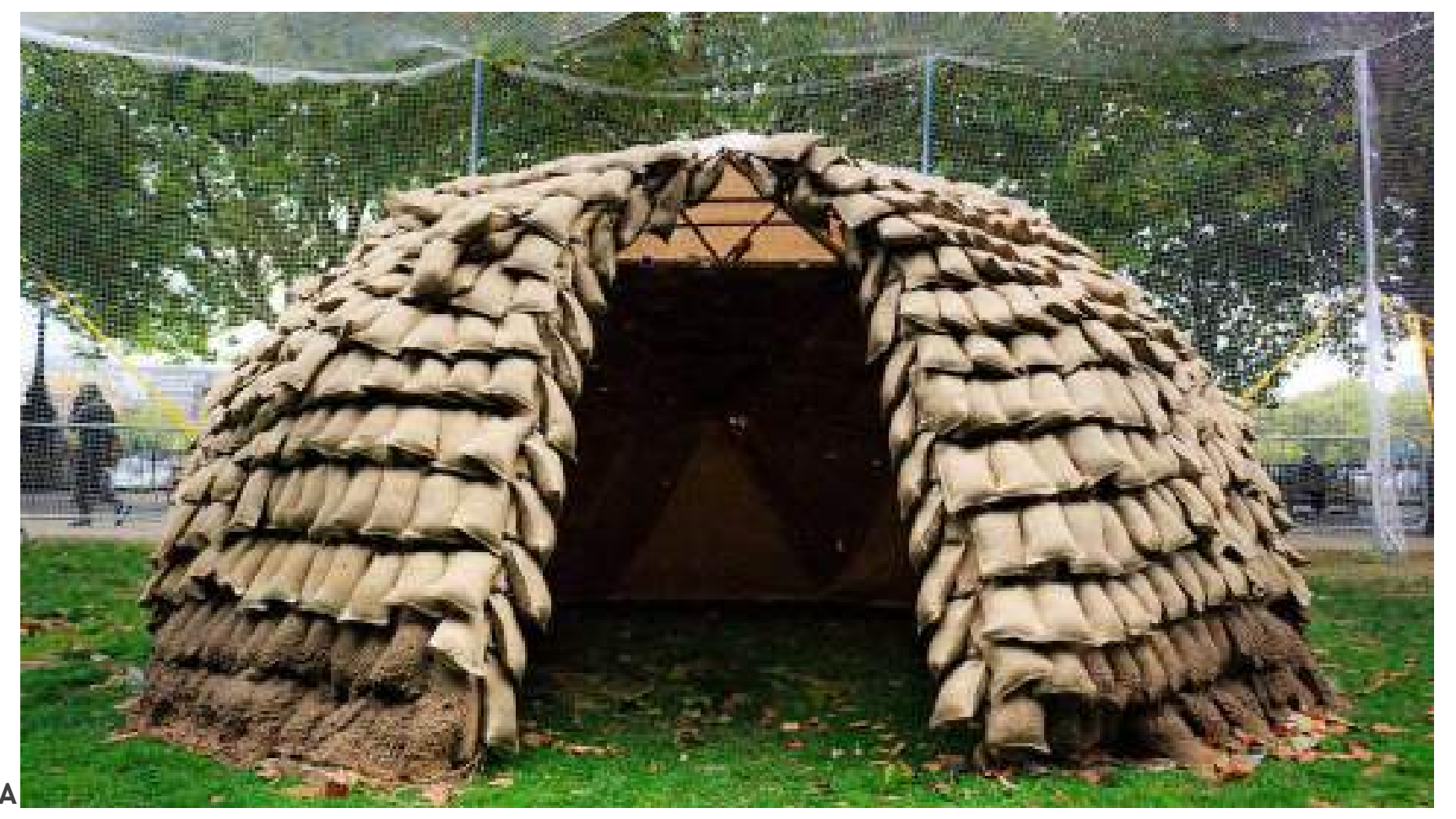

Retrieved from Dezeen (https://www.dezeen.com/awards/2019/shortlists/mud-shell) on 17 April 2020.

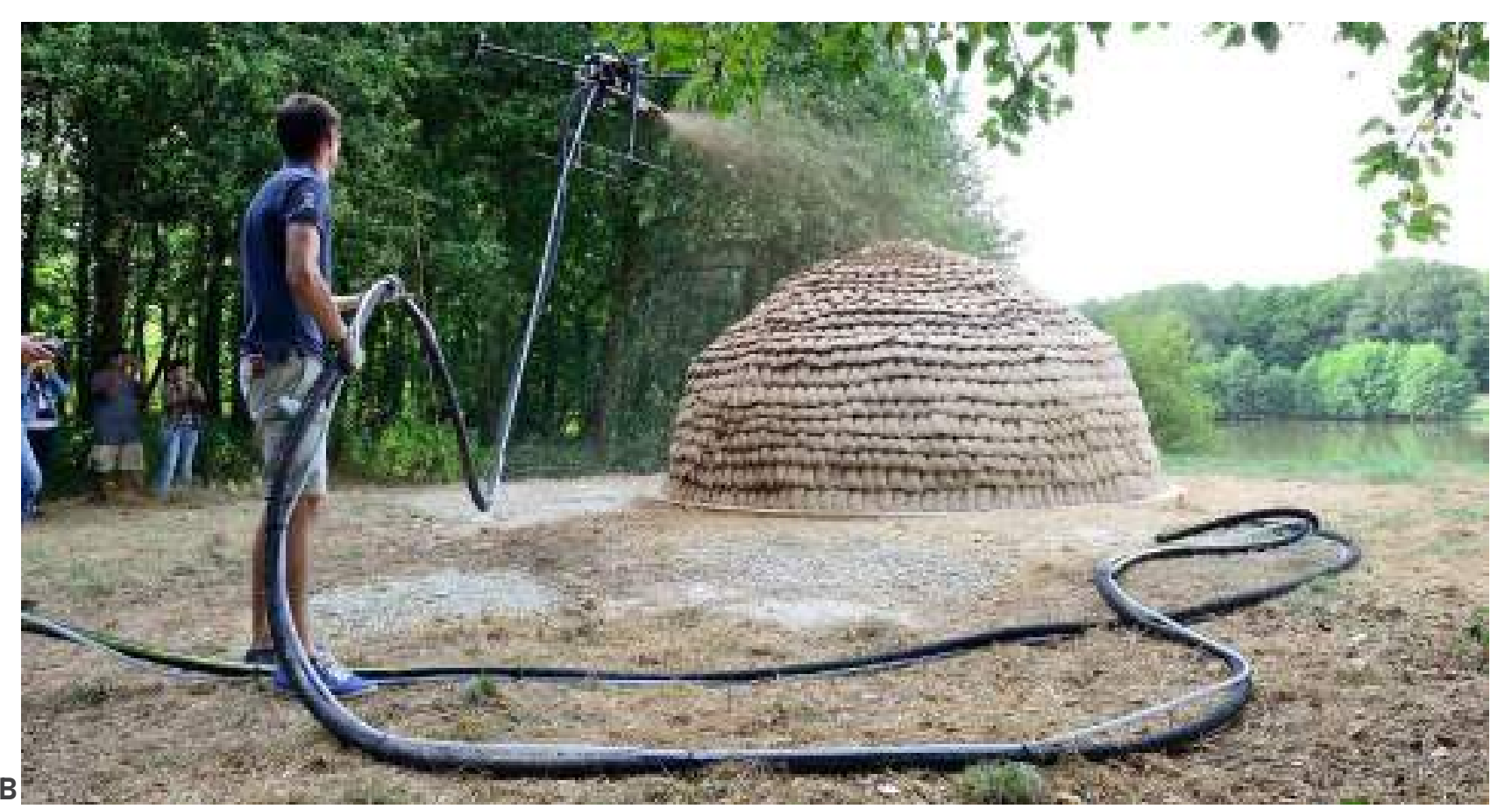

Note. The Mud Shell is a sturdy domed shelter constructed out of bags of hay attached to a wooden lattice that was
then sprayed with a mixture of clay and fibre stabilised

with lime using a drone.

(https://www. muddarchitects.com/) on 17 April 2020
Clay, bamboo and rice husk, Terramia, by MuDD Architects, Milan, 2019
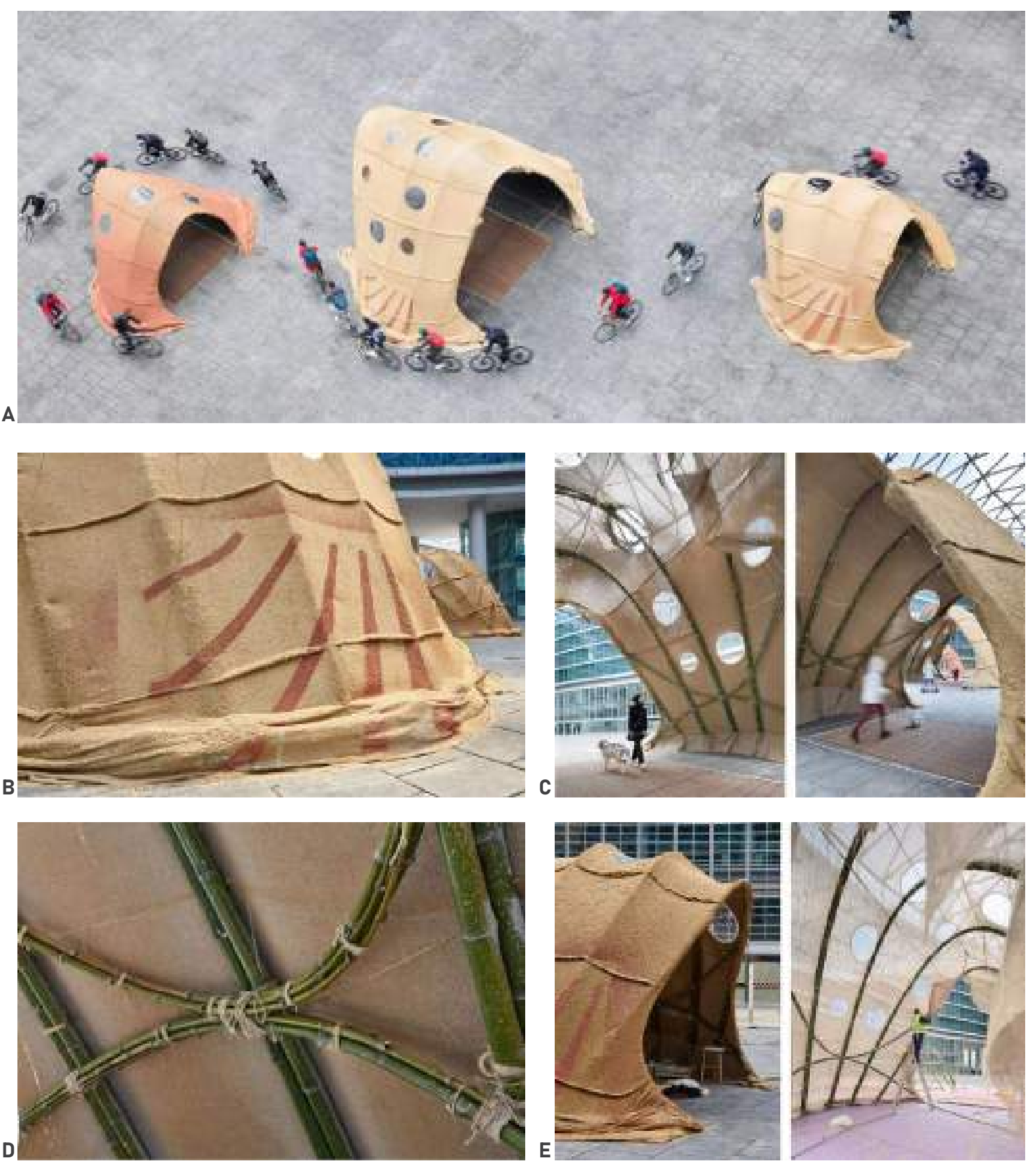

Note. The Terramia housing prototypes are entirely constructed out of the biodegradable materials of clay, bamboo and rice husks. The natural fibre fabric is sprayed by a drone with a bio-motar.

Retrieved from Design wanted (https://designwanted. com/architecture/mudd-architects/) on 17 April 2020. Last updated 24 January 2020
The Mud Shell (figure 23) and Terramia (figure 24) by biodegradable dwelling is a genuine goal for some modern designers. Although in many ways modern building monts have made achieving a biodegradable how it can make constructing a biodegradable dwelling easier. MDDD Architects demonstrate that achieving a $100 \%$ 
Untreated timber, Woodcube, Designed by architekturagentur Hamburg, Germany, 2013
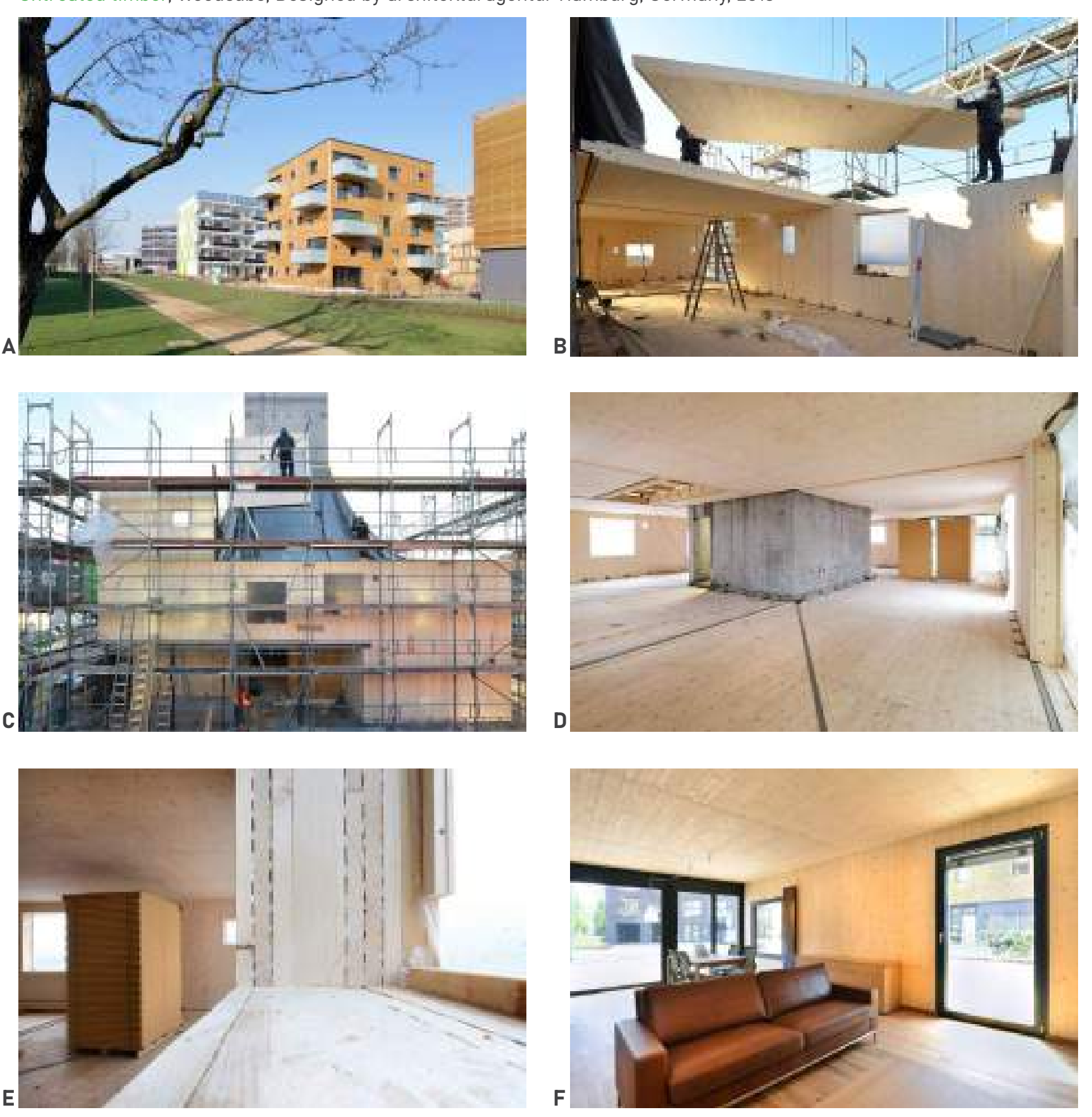

Photographs by Martin Kunze. Retrieved from ArchDaily (https://www.archdaily.com/421676/woodcube-architekturagentur) on 4 June 2020

The Woodcube is 5 storeys high and has 8 residential units with a net floor area of $900 \mathrm{~m}^{2}$. The $32 \mathrm{~mm}$ thick exterior wall and ceiling elements are prefabricated from unbounded non-coated cross-layered wooden boards which fixed together by traditional beech wooden dowel plugs.

The exterior wall elements are load bearing, thermally insulative and fire-resistant. To enhance the insulation performance of the wall system a $4 \mathrm{~cm}$ thick layer of wood soft fibreboard was added into the layers of the wall elements. Groves are engraved into the surface of the layered boards to create enclosed air cavities in the wall elements. The exterior walls boast a thermal resistance of R-12.8

The entire timber construction was examined by building biologists and has no added chemicals or glues so is $100 \%$ biodegradable as well as being completely deconstructable and reusable.
Figure 26

Raupo Hut, New Zealand

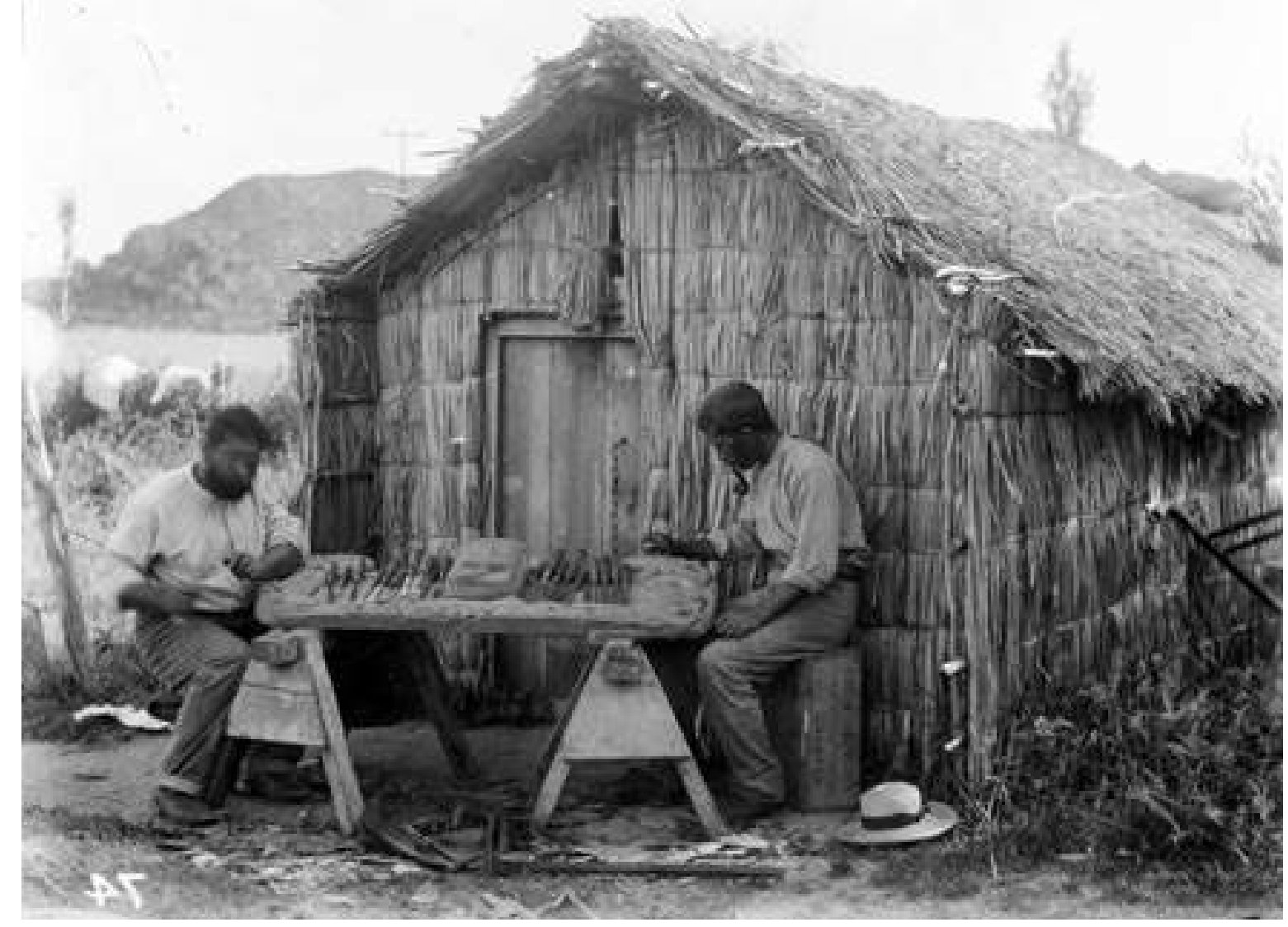

Retrieved from Auckland Museum (https://www.aucklandmuseum.com/collections-research/collections/ record/am_library-photography-234474) on 17 April 2020

Now that international biodegradable precedents have been explored the attention and focus will shift onto New Zealand. It is believed that Māori arrived on the shores of New Zealand from Polynesia in the late 13th century (Wilson, 2005). Māori were able to thrive in New Zealand's climate with shelters constructed solely of local biodegradable materials for centuries before nonbiodegradable building materials arrived in New Zealand. It is therefore wise to seek wisdom from the vernacular construction techniques of Măori in New Zealand before the arrival of non-biodegradable building materials.

The Raupo hut (figure 26) is an example of New Zealand's vernacular architecture before the arrival of nonbiodegradable building materials. Māori sourced their construction materials from surrounding forests and swamps (Salmond, 2010). Timber was used for structural poles, walls and ridge beams (Salmond, 2010). Rushes, bark or toetoe were used for thatching (Salmond, 2010). Te thatching was often woven through mânuka battens 2010). All joints were tied or woven (Salmond.

Biodegradable Materials of Māori

\begin{tabular}{|l|l|l|l|l|l|l|}
\hline Timbers & mānuka & Other unspecified timbers & & & & \\
\hline Earthen Methods & Unspecified earthen methods & & & & & \\
\hline Thatching Materials & Grass & Bark & Reeds & Ferns & Rushes & Toetoe \\
\hline
\end{tabular}




\subsection{Biodegradable Architecture of the Early} Settlers

Figure 27

The Cuddy, Waimate, New Zealand

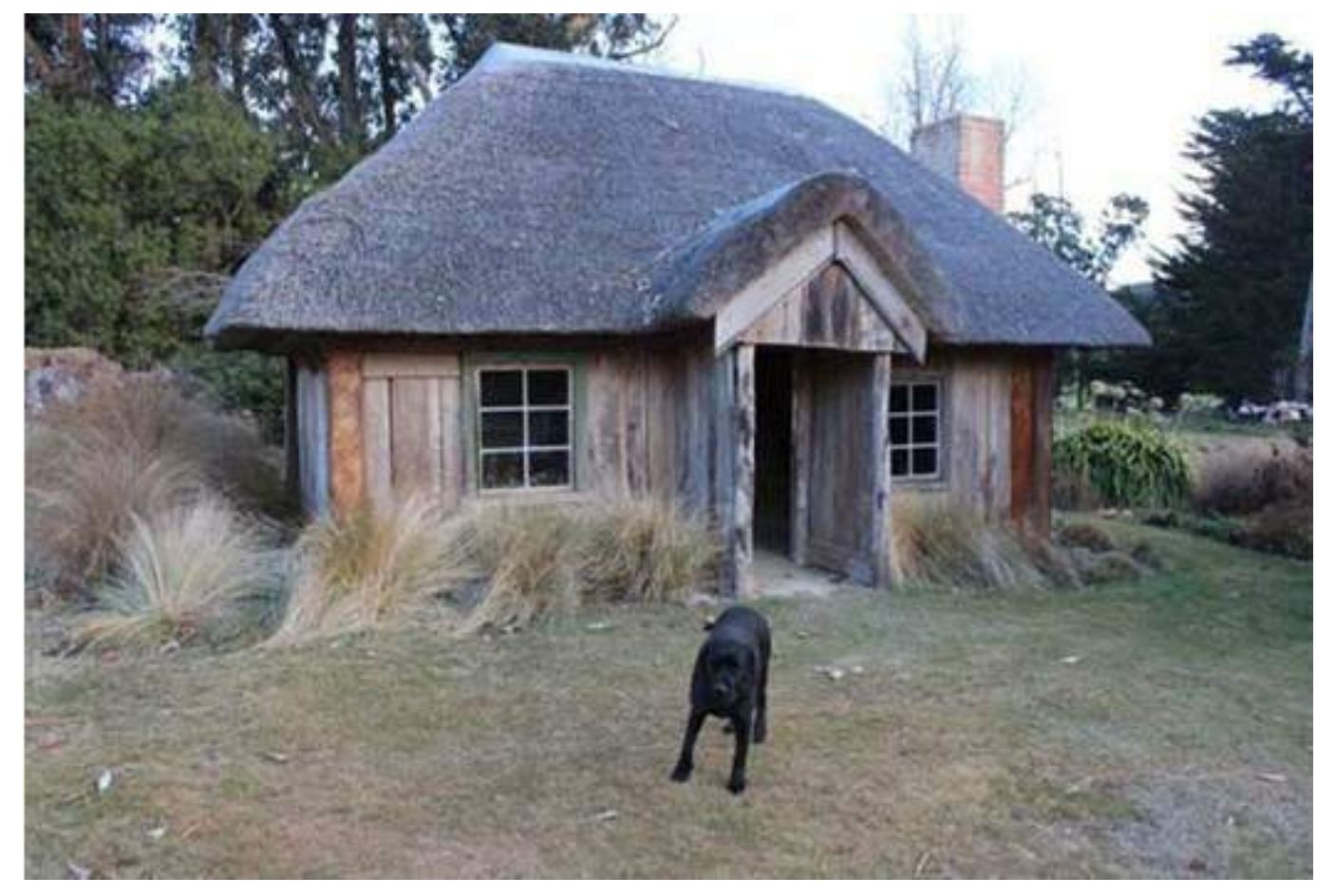

Photograph taken by P McGahan on 11 December 2012. Retrived from Heritage New Zealand (https://www.heritage.org.nz/the-list/details/49) on 17 April 2020. Copyright: Heritage New Zealand

When European settlers arrived in New Zealand so did the first non-biodegradable building materials. "The Cuddy" (figure 27) was built in 1854 in New Zealand's early European history after the arrival of non-biodegradable building materials such as glass in New Zealand. The dwelling has Totara walls, a thatched roof and is lined with wattle and daub (Wilson, 2017). The chimney is constructed of adobe bricks (Wilson, 2017)

Local biodegradable materials were still heavily relied on for the early construction of settler's homes. In Wellington local Māori helped settlers build shelters of wood, reed,

grass and bark (Salmond, 2010). In the 1840s and 1850s Settlers from the United Kingdom brought the techniques of wattle and dab adobe brick and cob to New Zealand (Hall, 2012). During this time New Zealand also saw construction sod, rammed earth, Kauri, Rimu, Tōtara and Matia (Salmond, 2010).

Timber was used for structural framing, cladding, flooring foundations and roofing (Salmond 2010) No building wrap layer insulation or drainage cavities were present. Fern fronds, reeds and bark sheets were also used as roofing materials (Salmond, 2010).

Biodegradable Materials of Early Settlers

\begin{tabular}{|l|l|l|l|l|l|}
\hline Timbers & Tōtara & Kauri & Rimu & Matai & \\
\hline Earthen Methods & Wattle and Daub & Adobe Bricks & Cob & Rammed Earth & Sod \\
\hline Thatching Materials & Grass & Bark & Reeds & Ferns & \\
\hline
\end{tabular}

\subsection{Biodegradable Architecture in NZ Today}

Figure 28

Earthship Te Timatanga, Hikuai, Waikato, New Zealand

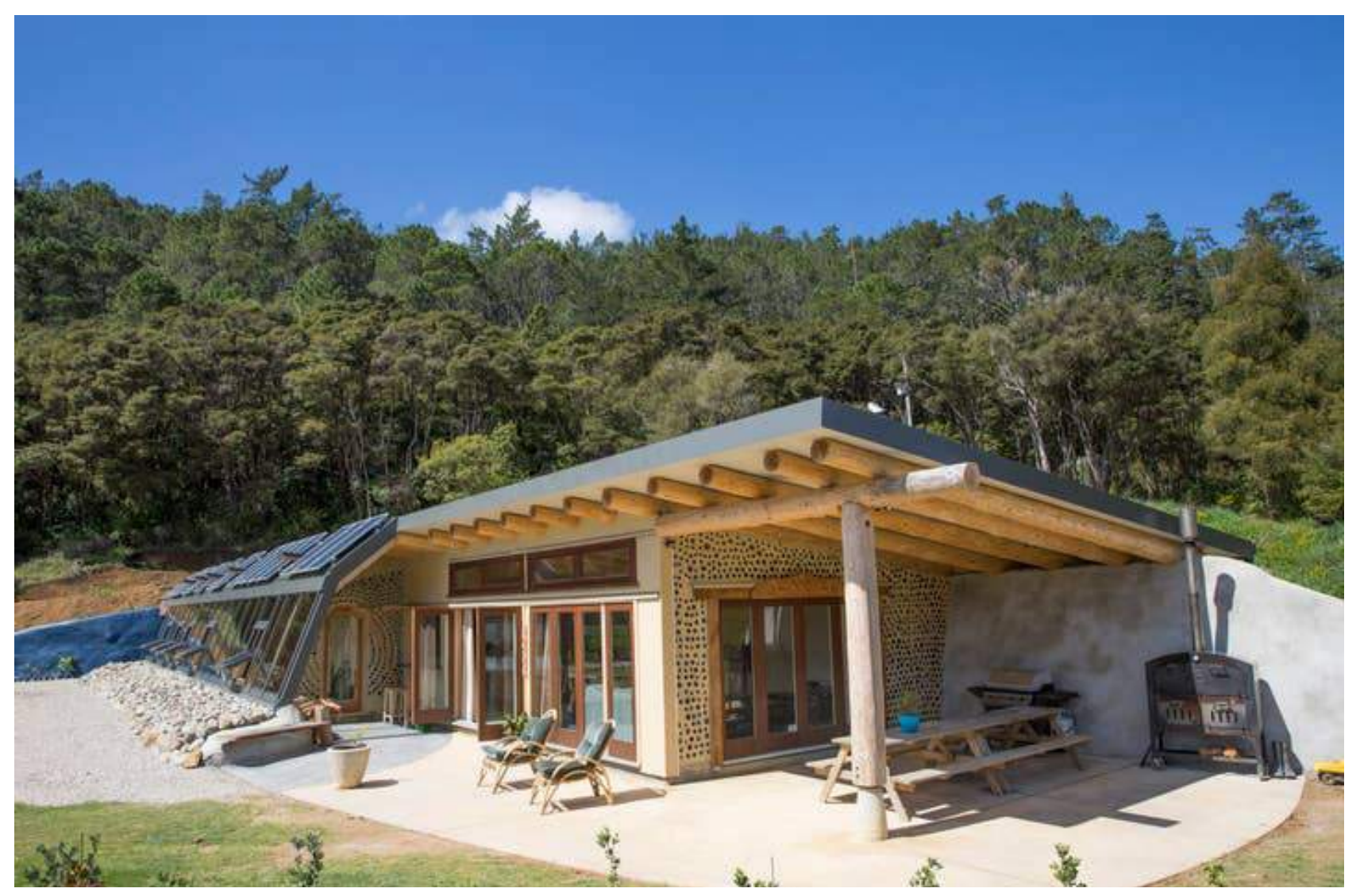

Note. House constructed of Timber and earth rammed into old car tyres. Retrieved from Airbnb (https://www.airbnb.co.nz/ rooms/10812145?source_impression_id=p3_1584396151_Gjjgl|11L_AT\%2F783MP) on 4 April 2020. Today the development of high-performing non-
biodegradable building materials has dramatically increased and bukn over the market This has led to biodegradabl building meterials falling out of fovour. This biocleged in New Zealand and most of the western world after the industrial revolution Constructions like the Raupo hut or The Cuddy are no longer being constructed. However the use of biodegradable building materials is still being pursued by natural building enthusiasts who albeit represent a vast minority of the poputation.

The Earthship Te Timatanga (figure 28), is a modernday New Zealand example of an attempt to increase buildings. The design is predominantly constructed out of timber and earth but contains metal roofing, aluminium

joinery and waterproof membranes. Unfortunately, in our modern age, even natural building enthusiasts often have little motivation to find a biodegradable alternative for these common materials as they are cheap and effective (Kennedy et al 2014). As a result many modern-day examples of biodegradable buildings are only partly

biodegradable. buildings are still standing in New Zestly biodegradab alone, there are 144 dwellings built after 1945 constructed of earth and/or straw bales (Hall, 2012). In addition, the use of earth and straw bale for building houses has increased over the past 60 years and has dramatically increased in the last 20 years (Hall, 2012). The presence of the Earth Building Standards has also given earth building credibility in New Zealand (Hall, 2012) 


\subsection{List of Biodegradable Materials}

Biodegradable Materials Globally

\begin{tabular}{|l|l|}
\hline Vernacular & Contemporary \\
\hline Cob & Cob \\
\hline Adobe Block & Adobe Block \\
\hline Rammed Earth & Rammed Earth \\
\hline Wattle and Daub & Wattle and Daub \\
\hline Bamboo & Bamboo \\
\hline Clay Plaster & Clay Plaster \\
\hline & Lime Plaster \\
\hline & Straw Bale \\
\hline & Earth Bags \\
\hline & Cork \\
\hline & Mycelium \\
\hline Reeds & \\
\hline Wood & Untreated Timber \\
\hline Wool & Wool \\
\hline & Hemp \\
\hline & Cellulose Insulation \\
\hline Seaweed & Seaweed \\
\hline Thatch & Thatch \\
\hline Sod & Sod \\
\hline & Wood Fibre Insulation \\
\hline
\end{tabular}

These tables list the vernacular and contemporary biodegradable materials internationally and in New Zealand. The list of international biodegradable materials were sourced from the precedent review and from The natural building companion : a comprehensive guide to integrative design and construction, 2012 by Jacob Deva Racusin and "The Art of Natural BuildingSecond Edition", 2014 by Joseph Kennedy. The list of biodegradable materials used globally is not exhaustive but a useful background context for comparison against New Zealand's biodegradable materials. New Zealand's vernacular and contemporary biodegradable materials
Biodegradable Materials in New Zealand

\begin{tabular}{|l|l|}
\hline Vernacular & Contemporary \\
\hline Cob & Cob \\
\hline Adobe Block & Adobe Block \\
\hline Rammed Earth & Rammed Earth \\
\hline Wattle and Daub & Wattle and Daub \\
\hline & \\
\hline & Clay Plaster \\
\hline & Lime Plaster \\
\hline & Straw Bale \\
\hline & Earth Bags \\
\hline & \\
\hline & \\
\hline & \\
\hline Wood & Untreated Timber \\
\hline Wool & Wool \\
\hline & Hemp \\
\hline & \\
\hline & \\
\hline Thatch & \\
\hline Sod & Sod \\
\hline & \\
\hline
\end{tabular}

\section{Most Suitable Biodegradable Materials For New Zealand}

were sourced from the preceding literature review and based on the table of global materials. Both these tables are approximate but provide a useful indication of what materials have endured and been used in New Zealan from the global context. In the next chapter, the materials listed in the global biodegradable materials table are analysed thoroughty to determine their surtability for use in New Zealand based on avallability and pefformance. Through this process, the most suitable materials for New Zealand from the New Zealand biodegradable materia

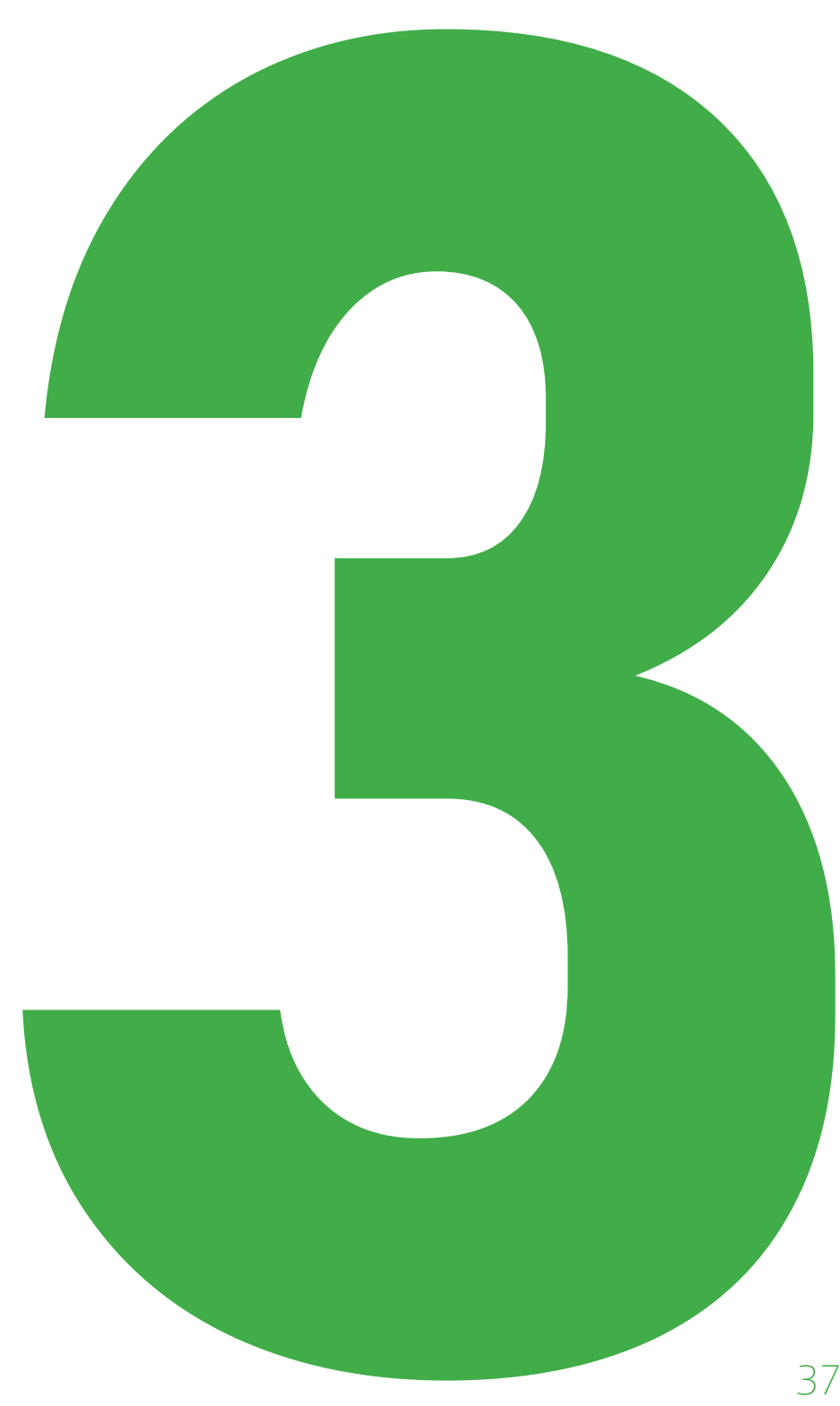




\section{Chapter Outline}

The previous chapter produced a list of biodegradable cladding, flooring, and foundations. This is because each building materials used in New Zealand and around the building element has unique performance requirements. The world throughout history. However, the suitability of these optimum biodegradable building material is then selected This chals for application in New Zealand varies greatly. for each element based on its availability and performance biodegradable building materials for New Zealand using for New Zealand is produced at the end of the chapter. This the list of materials produced in the previous chapter contributes towards the third thesis objective of finding the The building's construction is broken down into six most suitable biodegradable construction approach for New constituent elements - roofing, structure, insulation, Zealand

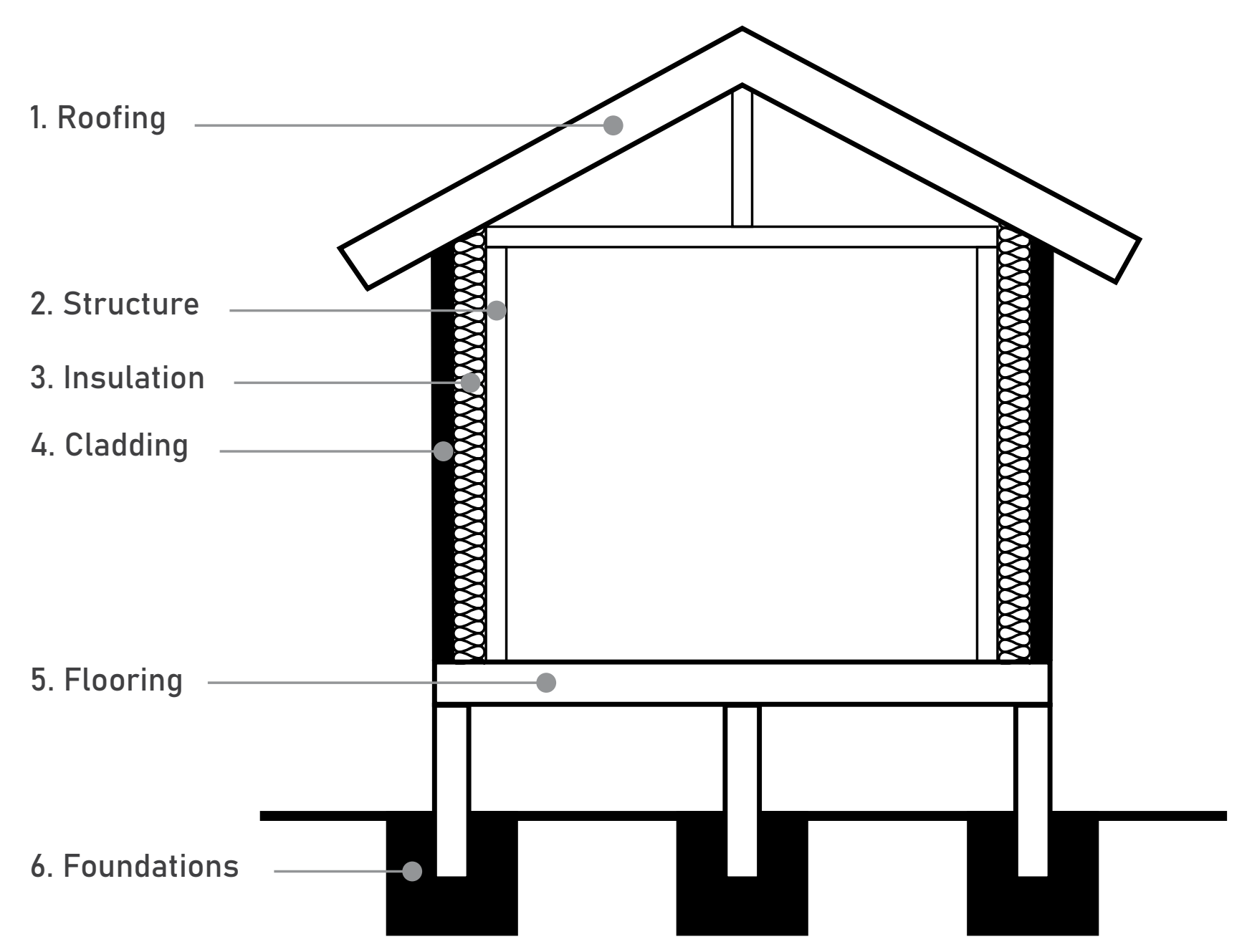




\subsection{Structural Systems}

\section{Performance Requirement:}

From NZBC B1 Structure "Buildings will withstand likely loads, including wind, earthquake, live and dead loads (people

\begin{tabular}{|c|c|c|c|c|c|c|}
\hline Material & Vernacular Precedent & Contemporary Precedent & Availability & Strengths & Weaknesses & \begin{tabular}{|l} 
Overall \\
Suitability \\
\end{tabular} \\
\hline \multirow[t]{2}{*}{ Cob } & & & \multirow[t]{2}{*}{ Moderate } & \multirow[t]{2}{*}{$\begin{array}{l}\text { - High compressive strength } \\
\text { - High thermal mass } \\
\text { - Earth building standard eases the } \\
\text { consenting process }\end{array}$} & \multirow[t]{2}{*}{$\begin{array}{l}\text { - Poor weather resistance } \\
\text { - Heavy } \\
\text { - Poor insulation coefficient } \\
\text { - Poor performance in earth quakes }\end{array}$} & \multirow[t]{2}{*}{ Low } \\
\hline & $\begin{array}{l}\text { Retrieved from Design boom (https://www.designboom. } \\
\text { com/architecture/musgum-earth-architecture/) on } 17 \\
\text { April 2020. }\end{array}$ & $\begin{array}{l}\text { Retrieved from This Cob House (https://www. } \\
\text { thiscobhouse.com/cob-workshop-meadow- } \\
\text { creek-mountain-ranch-part-1/) on } 29 \text { April } \\
2020 \text {. }\end{array}$ & & & & \\
\hline \multirow[t]{2}{*}{ Adobe Block } & ali & & \multirow[t]{2}{*}{$\begin{array}{l}\text { High: } \\
\text { produced in NZ by Solid } \\
\text { Earth Adobe Buildings }\end{array}$} & \multirow[t]{2}{*}{$\begin{array}{l}\text {-High compressive strength } \\
\text {-High thermal mass } \\
\text { - Earth building standard eases the } \\
\text { consenting process }\end{array}$} & \multirow[t]{2}{*}{$\begin{array}{l}\text { - Poor weather resistance } \\
\text { - Heavy } \\
\text { - Poor insulation coefficient } \\
\text { - Poor performance in earth quakes }\end{array}$} & \multirow[t]{2}{*}{ Moderate } \\
\hline & $\begin{array}{l}\text { Note. Mud bricks for building houses are sun dried } \\
\text { at a Tonga fishing village on Lake Kariba, Zimbabwe. } \\
\text { Retrieved from Alamy (https://www.alamy.com/mud- } \\
\text { bricks-for-building-houses-are-sun-dried-at-a- } \\
\text { tonga-fishing-village-on-lake-kariba-zimbabw) on } 19 \\
\text { May } 2020\end{array}$ & \begin{tabular}{|l} 
Retrived from Solid Earth (https://www. \\
solidearth.co.nz/products-and-services/ \\
adobe-manufacture/) on 30 April 2020
\end{tabular} & & & & \\
\hline \multirow[t]{2}{*}{$\begin{array}{l}\text { Rammed } \\
\text { Earth }\end{array}$} & 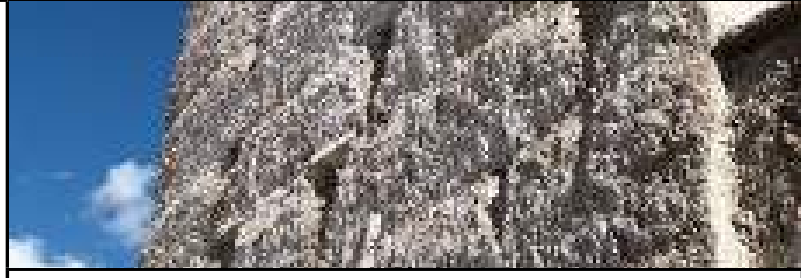 & 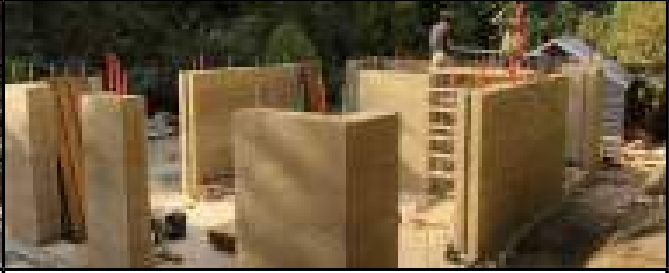 & \multirow[t]{2}{*}{\begin{tabular}{|l|} 
High: \\
Produced in NZ by Terra \\
Firma and Down to \\
Earth Building
\end{tabular}} & \multirow[t]{2}{*}{$\begin{array}{l}\text {-High compressive strength } \\
\text {-High thermal mass } \\
\text { - Earth building standard eases the } \\
\text { consenting process }\end{array}$} & \multirow[t]{2}{*}{\begin{tabular}{|l}
-Poor weather resistance \\
- Heavy \\
- Poor insulation coefficient \\
- Requires steel reinforcing and \\
cement stabilisers to provide \\
adequate structure to resist lateral \\
loads
\end{tabular}} & \multirow[t]{2}{*}{ Moderate } \\
\hline & $\begin{array}{l}\text { Note. Basgo fort, possibly constructed before } \\
\text { 1357. Retrieved from ResearchGate (https://www. } \\
\text { researchgate.net/figure/Basgo-fort-possibly- } \\
\text { constructed-before-1357_fig1_273221030) on } 19 \text { May } \\
\text { 2020. }\end{array}$ & \begin{tabular}{|l} 
Retrived from Earth Homes (https://www. \\
earthhomes.co.nz/Portfolio?mv_pc=6038) on \\
30 April 2020
\end{tabular} & & & & \\
\hline \multirow[t]{2}{*}{$\begin{array}{l}\text { Clay or } \\
\text { Lime- } \\
\text { plastered } \\
\text { Straw Bale }\end{array}$} & $\begin{array}{l}\text { Baled straw wasn't } \\
\text { produced until the late } \\
\text { 1800s }\end{array}$ & & \multirow[t]{2}{*}{$\begin{array}{l}\text { High: } \\
\text { Straw bale produced } \\
\text { in NZ } \\
\text { High: } \\
\text { Clay-plaster produced } \\
\text { in NZ by Solid Earth } \\
\text { Adobe Buildings }\end{array}$} & \multirow[t]{2}{*}{\begin{tabular}{|l|} 
- Highly insulative \\
- Resistant to lateral loads \\
- Moderate compressive strength \\
- Straw bale and clay plaster \\
construction has been tested regarding \\
seismic performance in Pakistan in \\
2009. The straw bale house performed \\
extremely well.
\end{tabular}} & \multirow[t]{2}{*}{$\begin{array}{l}\text {-Not suitable for construction over } \\
\text { 1-storey } \\
\end{array}$} & \multirow[t]{2}{*}{ Moderate } \\
\hline & & \begin{tabular}{|l|} 
Retrieved from Simple Construct (https:// \\
simpleconstruct.net/natural-plasters/ \\
plastering-straw-bale/) on 19 May 2020
\end{tabular} & & & & \\
\hline
\end{tabular}




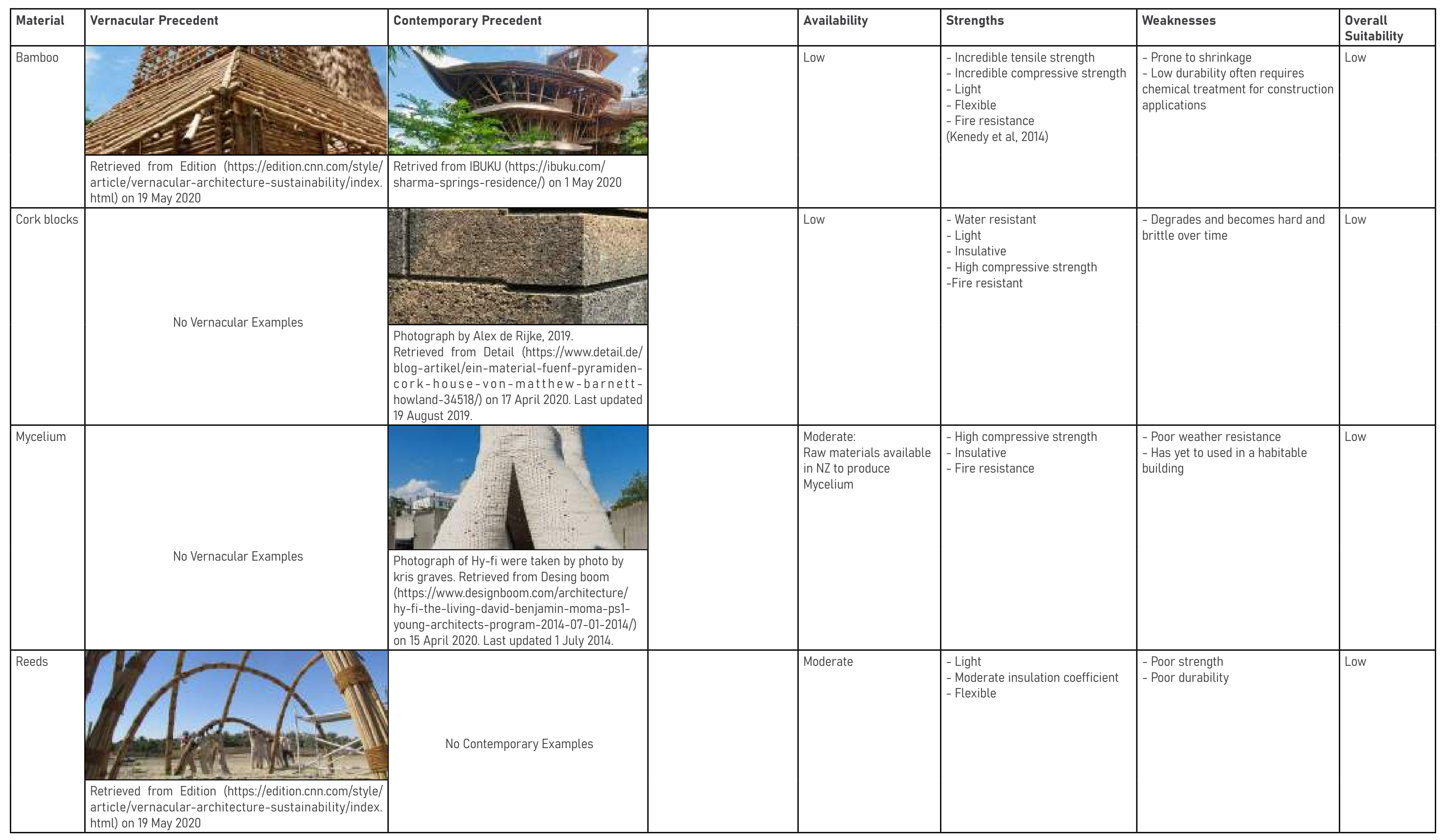




\begin{tabular}{|c|c|c|c|c|c|c|}
\hline Material & Vernacular Precedent & Contemporary Precedent & Availability & Strengths & Weaknesses & $\begin{array}{l}\text { Overall } \\
\text { Suitability }\end{array}$ \\
\hline $\begin{array}{l}\text { Untreated Douglas } \\
\text { Fir Heartwood }\end{array}$ & $\begin{array}{l}\text { Kauri, Rimu and Matai were } \\
\text { previously used as framing } \\
\text { timbers in NZ but are no longer } \\
\text { available }\end{array}$ & $\begin{array}{l}\text { Retrived from Douglas Fir (https:/douglasfir. } \\
\text { conz/net/buildwith/solutions.aspx) on } 30 \text { April } \\
2020\end{array}$ & $\begin{array}{l}\text { High: } \\
\text { highly produced in NZ }\end{array}$ & $\begin{array}{l}\text {-Flexible to resist lateral loads } \\
\text {-Light } \\
\text {-High level of experience with the } \\
\text { material in the industry } \\
\text { - } 20-30 \text { life span without weather } \\
\text { exposure } \\
\text { - Modulus of elasticity } \quad 10 \mathrm{GPa} \\
\text { - Bending strength } \quad 78 \mathrm{MPa} \\
\text { (httpp://www.nzwood.co.nz/forestry-2/ } \\
\text { douglas-fir/) }\end{array}$ & $\begin{array}{l}\text { - Moderate Durability } \\
\text { - Use of untreated Douglas-fir } \\
\text { structural timber beyond a single } \\
\text { household unit of no more than } \\
\text { two storeys is considered an } \\
\text { alternative solution under the } \\
\text { NZBC and will require quality } \\
\text { detailing to get construction } \\
\text { consented }\end{array}$ & High \\
\hline $\begin{array}{l}\text { Untreated } \\
\text { Macrocarpa } \\
\text { Heartwood }\end{array}$ & $\begin{array}{l}\text { Kauri, Rimu and Matai were } \\
\text { previously used as framing } \\
\text { timbers in NZ but are no longer } \\
\text { available }\end{array}$ & $\begin{array}{l}\text { Retrieved from NZ Wood (http://www.nzwood. } \\
\text { co.nz/forestry-2/macrocarpa/) on } 4 \text { May } 2020\end{array}$ & $\begin{array}{l}\text { High: } \\
\text { Moderate production } \\
\text { in NZ }\end{array}$ & $\begin{array}{l}\text {-Flexible to resist lateral loads } \\
\text { - Light } \\
\text { - High level of experience with the } \\
\text { material in the industry } \\
\text { - } 20 \text {-30 life span without weather } \\
\text { exposure } \\
\text { - Modulus of elasticity } \quad 5.79 \mathrm{GPa} \\
\text { - Bending strength } \quad 87.8 \mathrm{MPa} \\
\text { - Compression strength parallel to the } \\
\text { grain 44.6 MPa } \\
\text { - Shear strength parallel to the grain } \\
12.7 \mathrm{MPa} \\
\text { (http://www.nzwood.co.nz/forestry-2/ } \\
\text { macrocarpa/) }\end{array}$ & - Moderate Durability & Moderate \\
\hline
\end{tabular}

\section{NZ Timber for Structure}

Untreated Douglas-fir heartwood framing was found to be the most suitable structural system for New Zealand. This is because it is highly available in New Zealand and performs well due to its strength and workability Another species of timber that is considered durable enough to be untreated and have sufficient bearing capacity for structural application is Macrocarpa However Macrocarpa framing is not as available as Douglas-fir.

Since the arrival of the settlers to New Zealand, timber has been the predominant structural material, increasing from 79\% of houses in 1858 to $90 \%$ in 1911 (Isaacs, 2010a). In 2017, $90 \%$ of new dwellings in New Zealand were still timber-framed (Brunsdon \& Magan, 2017). It has been an enduring construction technique because of its availability, lightness, ease of use and its effectiveness against resisting earthquakes (Isaacs, 2010a)

Amendment 7 to B2/AS1 in April 2011, now allows the use of untreated Douglas-fir for roof, floor and external and internal wall framing in New Zealand buildings provided are all met (BRANZ, 2020b). 3.2.2.2 requires that the framing is protected from weather or contact with the ground, that the building has a low complexity exterior, has a vented cavity and a simple roof of slope greater than $10^{\circ}$ with eaves greater than $600 \mathrm{~mm}$ (BRANZ, 2020b).

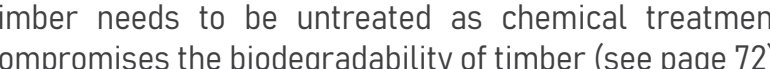




\subsection{Wall Insulation}

\section{Performance Requirement:}

--Under the NZBC B2, Insulation must last at least 50 years

--Ensure exterior temperature as minimal effect on the desired interior temperature

\section{AVAILABILITY KEY}

Moderate= Raw materials present in NZ

Low $=$ Imported product

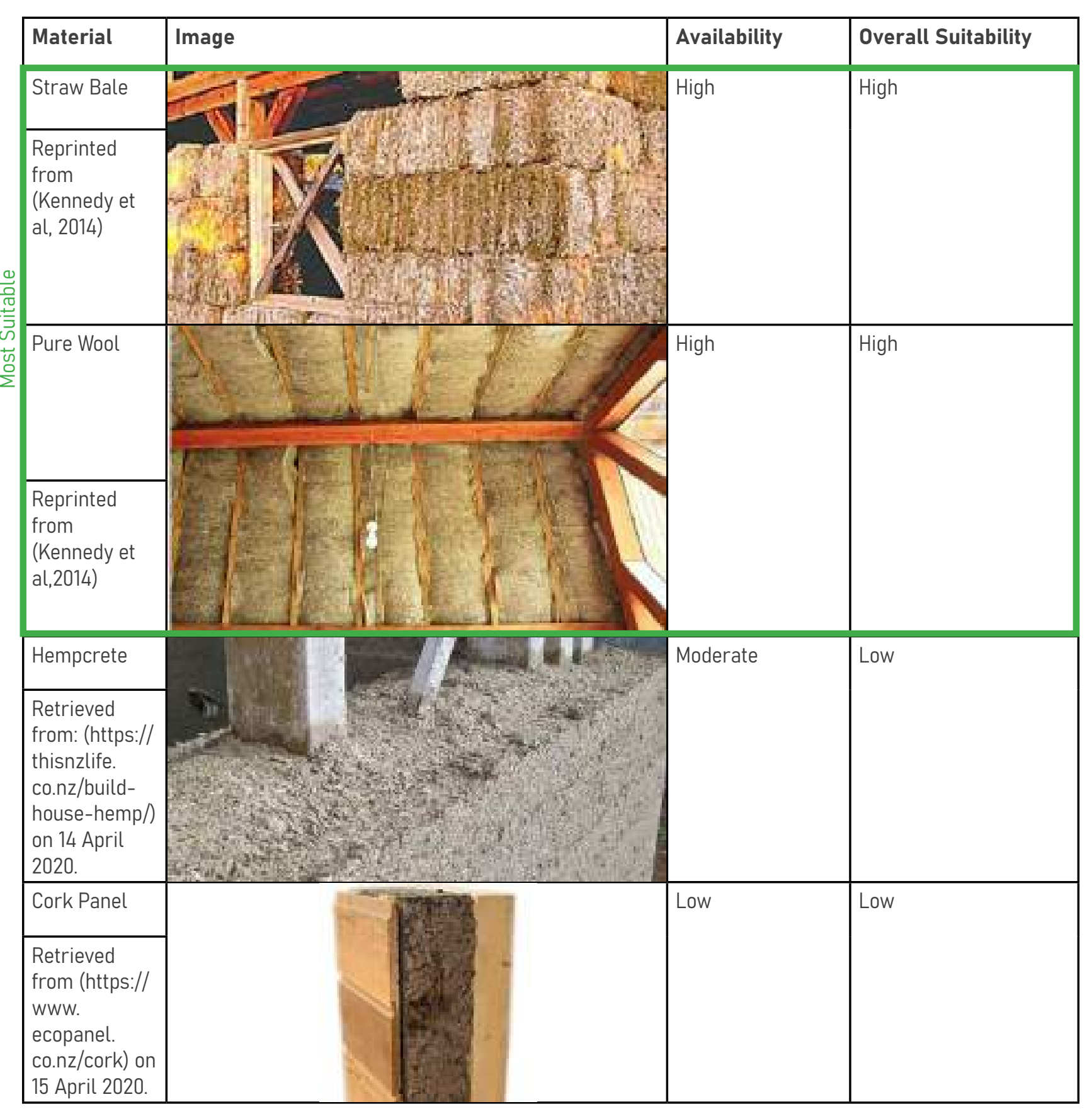

\begin{tabular}{|c|c|c|c|}
\hline Material & Image & Availability & $\begin{array}{l}\text { Overall } \\
\text { Suitability }\end{array}$ \\
\hline Mycelium & & $\begin{array}{l}\text { Moderate: } \\
\text { Raw materials }\end{array}$ & Low \\
\hline $\begin{array}{l}\text { Retrieved from (https://www. } \\
\text { buildinggreen.com/blog/ } \\
\text { greensulate---fungus-based- } \\
\text { insulation-material-thats- } \\
\text { grown-rather-manufactured) } \\
\text { on } 17 \text { April 2020. } \\
\end{array}$ & & produce Mycelium & \\
\hline Cellulose & & Low & High \\
\hline $\begin{array}{l}\text { Retrieved From (https://www. } \\
\text { detail.de/artikel/weg-fuer- } \\
\text { biobasierte-daemmstoffe- } \\
\text { bereiten-30179/) on } 17 \text { April } \\
2020 \text {. }\end{array}$ & & & \\
\hline Seaweed & & Moderate & Low \\
\hline \multicolumn{4}{|l|}{$\begin{array}{l}\text { Retrieved from (https:// } \\
\text { www.designboom.com/ } \\
\text { design/kathryn-larsen- } \\
\text { seaweed-prefab-thatch- } \\
\text { panels-03-04-2020/) on } 18 \\
\text { April 2020. }\end{array}$} \\
\hline Straw-Based Products & & Low & Low \\
\hline Reprinted from (Maxit, n.d.) & & & \\
\hline
\end{tabular}




\section{Performance Requirement:}

--Under the NZBC B2, Insulation must last at least 50 years

-Ensure exterior temperature as minimal effect on the desired interior temperature

\section{AVAILABILITY KEY}

High=Produced in NZ

Moderate= Raw materials present in NZ

Low $=$ Imported product

\begin{tabular}{|l|l|l|l|l|}
\hline Material & Image & Availability & Overall Suitability \\
\hline $\begin{array}{l}\text { Natural Fibre } \\
\text { Insulation (Flax, } \\
\text { Hemp, Jute) }\end{array}$ & & Low & Low \\
\hline $\begin{array}{l}\text { Retrieved from } \\
\text { (https://www. } \\
\text { detail.de/artikel/ } \\
\text { akzeptanz-von- } \\
\text { baumaterialen- } \\
\text { aus- } \\
\text { nachwachsenden- } \\
\text { rohstoffen-31767) } \\
\text { on 20 Aprit 2020 }\end{array}$ & $\begin{array}{l}\text { Wood Fibre } \\
\text { Insulation }\end{array}$ & & & \\
\hline $\begin{array}{l}\text { Retrieved from } \\
\text { Stich Passive } \\
\text { Design (http:// } \\
\text { stichpassivedesign. } \\
\text { com/passive- } \\
\text { house--roducts/ } \\
\text { wood-fibre-board/) } \\
\text { on 9 June 2020 }\end{array}$ & & & Low & \\
\hline
\end{tabular}

Performance criteria were not assessed for insulation. This is because thermal resistance and durability in terms of moisture resistance are the two main categories and all insulation materials have surficient thermat resistance and most apart from cork and hempcrete have poor moisture resistance. Therefore, the avallabilty or the piodegradable insulation material is the defining factor. Both straw bales

and pure wool insulation are produced in New Zealand, but the production of straw bales is significantly greater than that of pure wool insulation. Therefore, straw bales are the most suitable biodegradable insulation material for New Zealand followed by pure wool insulation. The situatio general, is discussed later in this thesis (see page 71).

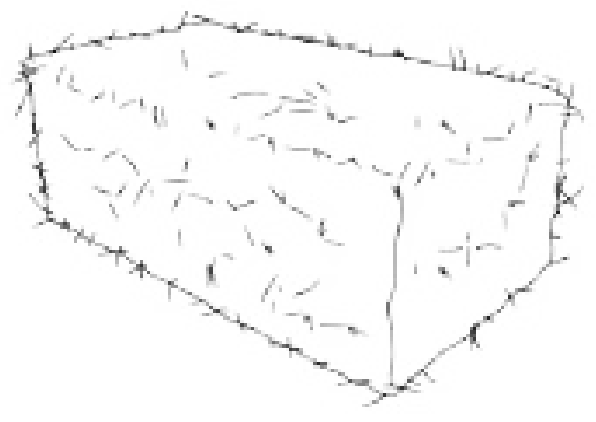

Straw bales are an abundant waste product of our agriculture industry. Straw bales are generally underutlised but are used for fertilser, animal beding and bio-fuel as well 2016).

Straw is the stem of the cereal plant from which the valuable head of wheat, barley, oats, rice or rye is harvested (Magwood, 2016). Bate sizes vary globally In New Z ond straw bas length, $450 \mathrm{~mm}$ wid and $350 \mathrm{~mm}$. Straw is oftenconfused Sraw is ofen cof nutrient grass used as animat feed (R. Pringte, 2016). Hay

\section{Figure 29}

Annual straw burn-off South Canterbury, 2012

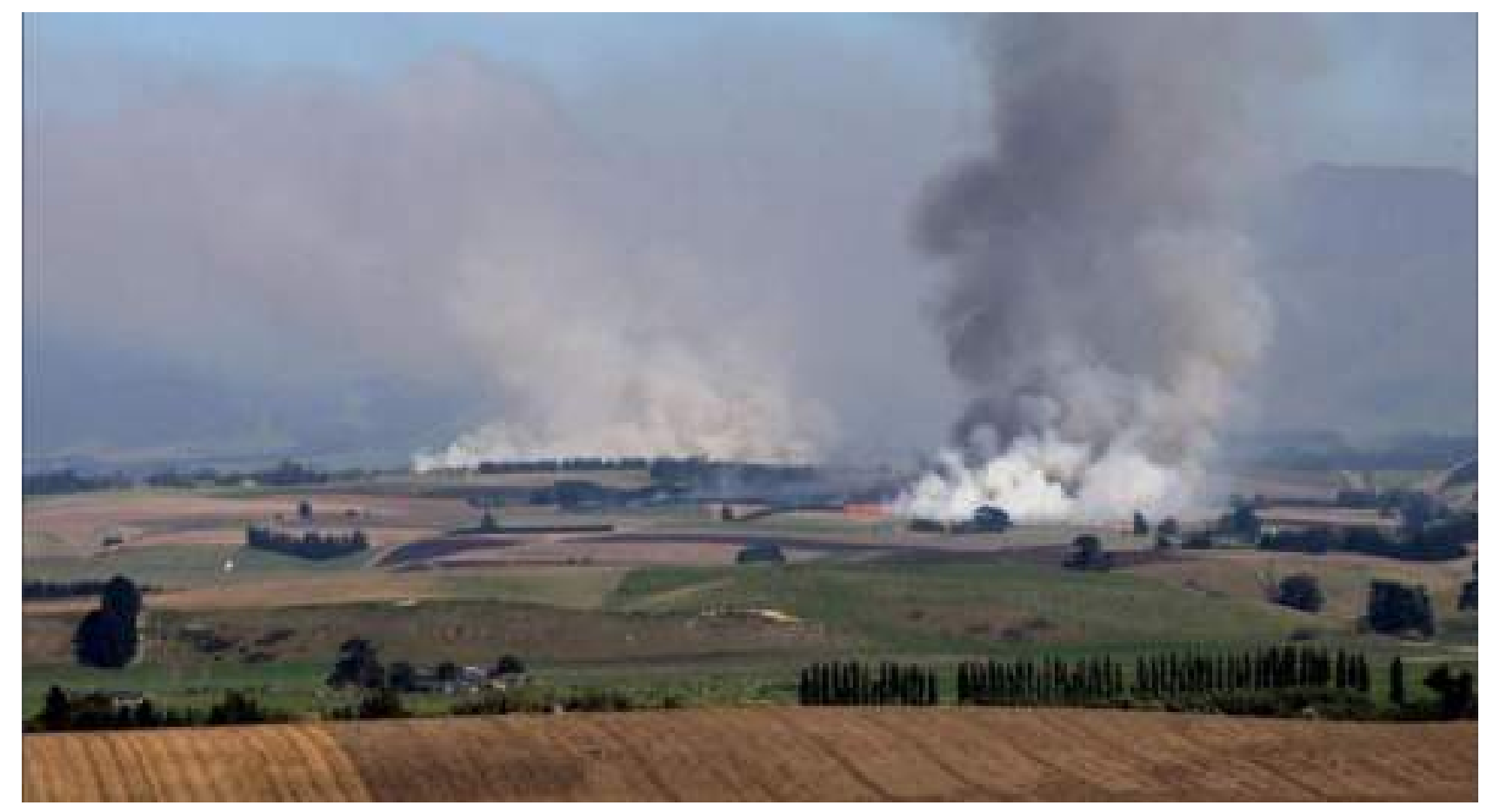

Photograph by John Bisset, 2012. Retrieved from (https://unitec.researchbank.ac.nz/bitstream/handle/10652/4145/1410 Min_Hall.pdf?sequence=1\&isAllowed=y) on 14 April 2020. contains much greater organic content than straw and is therefore not suitable for construction applications due to the risk of premature biodegradation. Both straw and hay prober cans bales by a baling machine which is the

Zealand's grain growing sector has the capacity to supply bale construction to grow in New Z $Z$ aland Currently (figure 29) (Hall, 2019). If this polluting and unsustainate

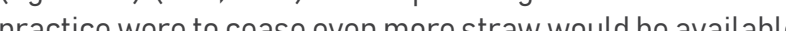
in New Zealand (R. Pringle, 2016). straw bales to construct 2,200 dwellings each year (Hall, estimated 20\% of straw is simply burned after harvest 
Straw bales have only been around since the first bailing machine which was invented in the late 1800s. Prior to that, however, loose straw has been used as a construction
material for hundreds of years (R. Pringle, 2016). Straw bales were first used in construction in the 1890s in Nebraska, USA (Menry, 2012). Many of the buildings from this time are still standing, he oldest of which is the Burke house in Alliance, Nebraska, built in 1903 (King, 2006).

It was not until grain was first cultivated in New Zealand in the mid-1800s that straw became available (R. Pringle, 2016). It then took a straw bale revival in the USA in the 1990 s for straw bale construction to finally gain enough interest to be used within New Zealand (R. Pringle, 2016). The first straw bale house in New Zealand was constructed in 1995 in Martborough designed by Peter Kundycki, a landscape architect and urban designer (figure 30) (Hall, 300 to 400 straw bale houses in New Zealand (Hall, 2015)
Most straw bale use in New Zealand is not load-bearing This construction approach has the advantage of being able to construct the roof before the straw bale wall wet. Significant pockets straw bale houses can be found in Northland, Waiheke Istand, the Coromandel, Nelson Otago (Hall, 2012). Statistics New Zealand's latest data from 2017 estimates that there are 1,729,300 in New Zealand (Statistics New Zealand, 2017). This shows that straw bale houses are a long way off even representing one percent of dwellings in New Zealand. However, although small, an industry for straw bale houses does Strawmark. Sol Design is a New Zealand organisation that natural building techniques. but used as infill amongst timber framing (BRANZ, 2015). infill thus reducing the possibility of the bales getting Tasman, Marborough, South Canterbury and Centra exist in New Zealand with a handrul of small companies specialising such as Straw Built Homes, The Little Pig and

Figure 30

New Zealand's Fist Straw Bale House, Marlborough, 1995

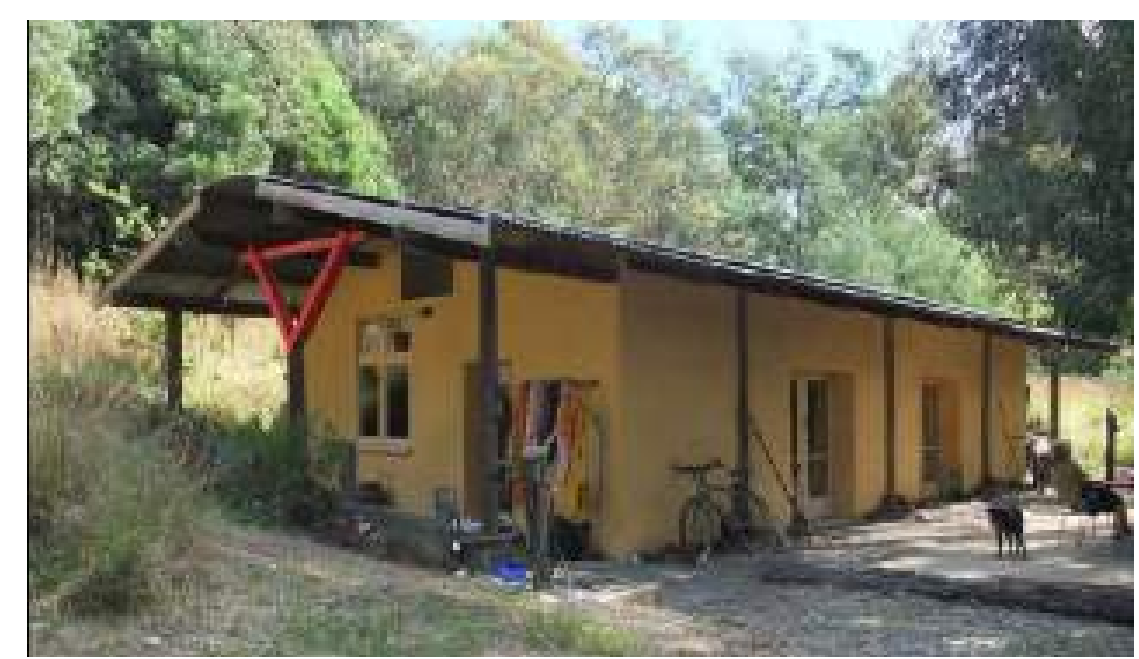

Photograph by Min Hall, 2012. Reprinted from "Earth and Straw Bale: An investigation of their performance and potential as building materials in New Zealand" by M. Hall, 2012, Victoria University of Wellington. Copyright 2012 by Min Hall.

\section{Figure 31}

New Zealand's Straw Bale Construction Companies or Consultants

\section{SO DESIGN $\odot$ Straw Built Homes}

\section{the little pig straujmark}

There are now companies in New Zealand that specialise in straw bale construction for homes such as Straw Built Homes, The Little Pig and Strawmark. Sol Design is a New Zealand organisation that offers workshops on straw bale construction and other natural building techniques. The presence of a competitive straw bale construction market New Zealand.
It is essential that the straw bales remain dry over their standard (Hall, 2019). The absence of a design standard whote life as the biodegradation process will commence means that all building code clause Bi structurat compliance in the presence of moisture (BRANZ, 2015). However, if design must be done by a chartered professional engineer the bales are kept dry they remain inert and can last for (BRANZ, 2015). This adds time, cost and effort making straw centuries. Straw has been found that is 7,000 years old bale construction less desirable. However, an informative (Kennedy et al., 2014).

straw bale construction appendix is likely to be present on the next revision of the New Zealand Earth Building Standards The uptake of straw bale construction is limited in New which, if accepted, will make the consenting process easier Zealand due to the absence of a straw bale building for all parties (Hall, 2019).

Pure Wool Insulation Overview

Figure 32

Pure NZ wool blown-in ceiling insulation from Envirowool

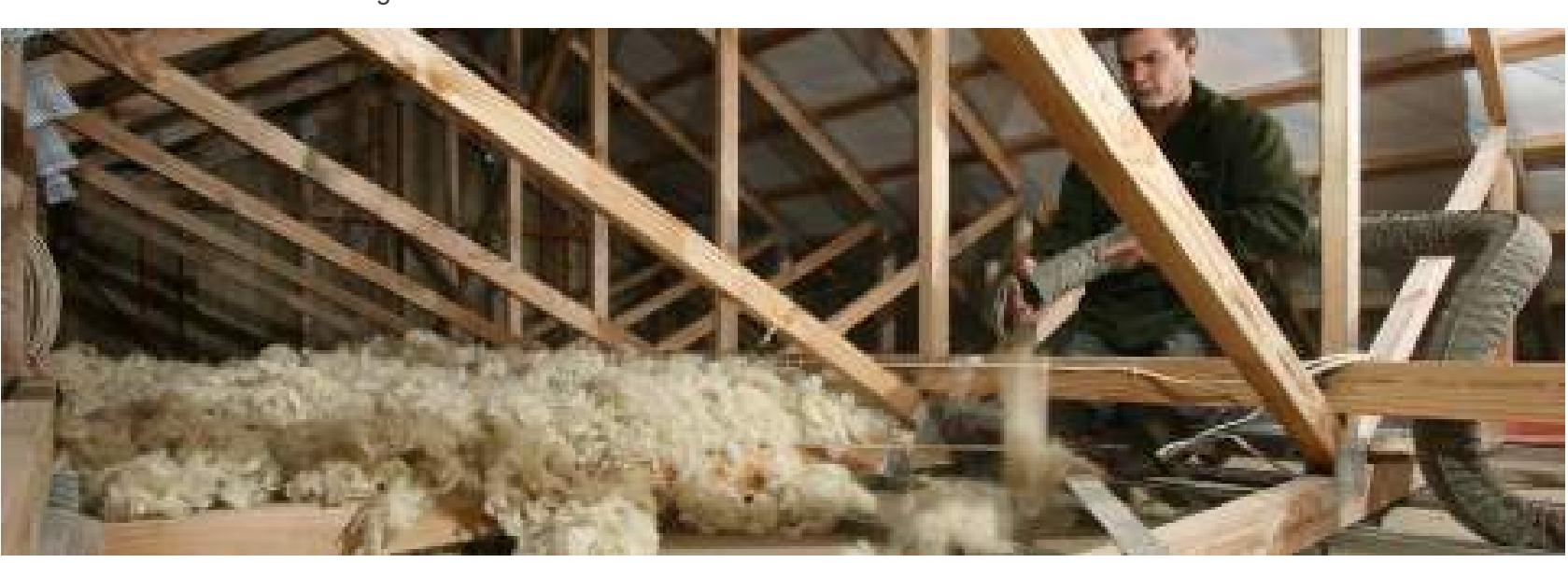

Retrieved from Envirowool (https://envirowool.co.nz/why-insulate/) on 13 September 2020

The potential for pure wool insulation in New Zealand like straw bales is great. New Zealand is one of the largest producers of wool in the world producing $11 \%$ of the world's wool and taking 4 th place behind Australia, China and the USA (Omondi, 2017). However, despite the abundance of wool produced in our country, only 30\% remains in the country and of that wool very little is used in insulation (Nicol \& Saunders, 2008). In addition, almost all of the wool used in insulation products in New Zealand is blended with polyester or combined with inorganic resins which compromises the biodegradability of the product. Manufacturers use inorganic resins or blend polys its with wol for a 2010). Pure wo he the product is not blended with polyester or inorganic resins is only available in New Zealand as loose blown-in roof insulation overseas in places such as the USA to produce pure wo insulation products. Havelock wool in the USA has made a parthership with Pâmu Farms of New Zealand to supply

Wool is highly insulative, more so than straw. The crimpled nature of the wool fibres traps millions of tiny air pockets. The exterior layer of a wool fibre is hydrophobic (waterresistant) but its inner layer, its cortex, is hydrophilic (water-loving) (Tuzcu, 2007). This means that wool can absorb up to $30 \%$ f is weight in moisture within its cortex capority ung most bio-banpromising its insulative materials (Tuzcu, 2007). 


\subsection{Wall Cladding}

\section{Performance Requirements}

- Under the NZBC B2, cladding must last at least 15 years

E2.3.2 Exterior walls must prevent the penetration of water that could cause undue dampness, damage to building elements

\begin{tabular}{|c|c|c|c|c|c|c|}
\hline Material & Vernacular Precedent & Contemporary Precedent & Availability & Strengths & Weaknesses & $\begin{array}{l}\text { Overall } \\
\text { Suitability }\end{array}$ \\
\hline $\begin{array}{l}\text { Clay-based Plaster } \\
\text { (Weatherproofed } \\
\text { with lime wash) }\end{array}$ & \begin{tabular}{|l|} 
\\
$\begin{array}{l}\text { Retrieved from Natural Homes (http:// } \\
\text { naturalhomes.org/timeline/gurunsi-house.htm) } \\
\text { on } 19 \text { May } 2020\end{array}$ \\
\end{tabular} & $\begin{array}{l}\text { Photograph by Min Hall, 2012. Reprinted from } \\
\text { "Earth and Straw Bale: An investigation of their } \\
\text { performance and potential } \\
\text { as building materials in New Zealand" by M. Hall, } \\
\text { 2012, Victoria University of Wellington. Copyright } \\
\text { 2012 by Min Hall. }\end{array}$ & $\begin{array}{l}\text { High: } \\
\text { Produced in NZ by Solid } \\
\text { Earth Adobe Buildings }\end{array}$ & $\begin{array}{l}\text { - Aids in keeping straw bales dry } \\
\text { - Seals straw bales for air } \\
\text { tightness and improved insulation } \\
\text { - Provides bracing to resist lateral } \\
\text { loads } \\
\text { - Increases structural integrity of } \\
\text { straw bale wall }\end{array}$ & $\begin{array}{l}\text { - Poor durability without lime } \\
\text { wash exterior finish } \\
\text { - Low strength (less than lime- } \\
\text { based plaster) }\end{array}$ & High \\
\hline $\begin{array}{l}\text { Lime-based } \\
\text { Plaster }\end{array}$ & No Vernacular Example & 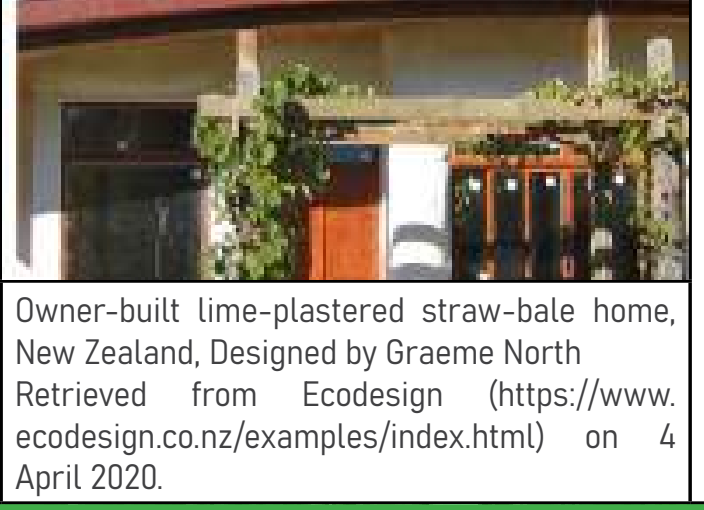 & \begin{tabular}{|l|} 
High: \\
Produced in NZ by Earth \\
Studio
\end{tabular} & $\begin{array}{l}\text { - Provides some Aid in keeping } \\
\text { straw bales dry } \\
\text { - Seals straw bales for air } \\
\text { tightness and improved insulation } \\
\text { - Provides bracing to resist lateral } \\
\text { loads } \\
\text { - Increases structural integrity of } \\
\text { straw bale wall }\end{array}$ & $\begin{array}{l}\text { - Moderate durability } \\
\text { - Moderate-High strength (less } \\
\text { than cement-based plaster) }\end{array}$ & High \\
\hline Seaweed & No Vernacular Example & $\begin{array}{l}\text { Retrieved from Dezeen (https://www.dezeen. } \\
\text { com/2013/07/10/the-modern-seaweed-house- } \\
\text { by-vandkunsten-and-realdania/) on } 13 \text { May } \\
2020\end{array}$ & Moderate & $\begin{array}{l}\text { - Offers additional insulation } \\
\text { - Salt from the seawater acts as a } \\
\text { preservative and slightly increases } \\
\text { durability }\end{array}$ & $\begin{array}{l}\text { - The vernacular skills that } \\
\text { brought success are essentially } \\
\text { dead today and non-existent in } \\
\text { NZ } \\
\text { - Poor durability } \\
\text { - Requires waterproof membrane } \\
\text { for water tightness } \\
\text { - Flammable }\end{array}$ & Low \\
\hline Thatch & $\begin{array}{l}\text { Retrieved from Edition (https://edition.cnn. } \\
\text { com/style/article/vernacular-architecture- } \\
\text { sustainability/index.html) on } 19 \text { May } 2020\end{array}$ & $\begin{array}{l}\text { Photographs by Damir Fabijanic, 2014. Retrieved } \\
\text { from Detail (https://www.detail.de/artikel/ } \\
\text { lokales-erbe-ferienhaus-in-kroatien-11897/) on } \\
17 \text { April 2020. Last updated } 11 \text { May 2014. }\end{array}$ & Moderate & $\begin{array}{l}\text { - Offers additional insulation } \\
\text { - History of use in NZ's vernacular } \\
\text { architecture }\end{array}$ & $\begin{array}{l}\text { - The vernacular skills are } \\
\text { essentially dead today in NZ } \\
\text { - Poor durability } \\
\text { - Requires waterproof membrane } \\
\text { for water tightness } \\
\text { - Flammable }\end{array}$ & Low \\
\hline
\end{tabular}




\begin{tabular}{|c|c|c|c|c|c|c|}
\hline Material & Vernacular Precedent & Contemporary Precedent & Availability & Strengths & Weaknesses & \begin{tabular}{|l} 
Overall \\
Suitability
\end{tabular} \\
\hline Cork Panel & No Vernacular Example & 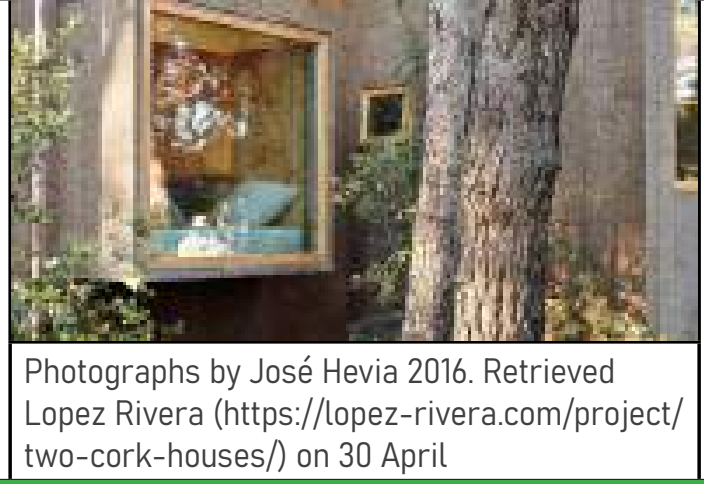 & Low & $\begin{array}{l}\text { - Moderate-high durability } \\
\text { - Water resistant } \\
\text { - Fire resistant } \\
\text { - Provides additional insulation }\end{array}$ & $\begin{array}{l}\text { - Waterproof membrane is common } \\
\text { underneath to ensure water tightness }\end{array}$ & Moderate \\
\hline $\begin{array}{l}\text { Untreated } \\
\text { Macrocarpa } \\
\text { Heartwood } \\
\text { Cladding } \\
\text { (weatherboards }\end{array}$ & $\begin{array}{l}\text { Kauri, Rimu and Totara were } \\
\text { previously used as cladding } \\
\text { timbers in NZ but are no longer } \\
\text { available }\end{array}$ & \begin{tabular}{|l|}
$\begin{array}{l}\text { Retrieved from NZ Natural Timber (https://www. } \\
\text { nznaturaltimber.co.nz/species/macrocarpa } \\
\text { cladding/) on } 6 \text { May } 2020\end{array}$ \\
\end{tabular} & High & $\begin{array}{l}\text { - Moderate Durability } \\
\text { - Will last 20-30 years when exposed } \\
\text { to weather (http://www.nzwood.co.nz/ } \\
\text { forestry-2/macrocarpa/) }\end{array}$ & $\begin{array}{l}\text { - Waterproof membrane is common } \\
\text { underneath to ensure water tightness } \\
\text { - Flammable }\end{array}$ & High \\
\hline $\begin{array}{l}\text { Untreated Douglas } \\
\text { Fir Heartwood } \\
\text { Cladding }\end{array}$ & $\begin{array}{l}\text { Kauri, Rimu and Totara were } \\
\text { previously used as cladding } \\
\text { timbers in NZ but are no longer } \\
\text { available }\end{array}$ & \begin{tabular}{|l|} 
\\
Retrieved from Abodo (https://www.abodo. \\
co.nz/products/timber/tundra-cladding) on 6 \\
May 2020
\end{tabular} & High & $\begin{array}{l}\text { - Moderate Durability } \\
\text { - Durability class } 3 \\
\text { - Will last } 15 \text {-20 years when exposed } \\
\text { to weather (http://www.nzwood.co.nz/ } \\
\text { forestry-2/douglas-fir/) }\end{array}$ & $\begin{array}{l}\text { - Waterproof membrane is common } \\
\text { underneath to ensure water tightness } \\
\text { - Flammable }\end{array}$ & Moderate \\
\hline $\begin{array}{l}\text { Untreated Siberian } \\
\text { larch Heartwood }\end{array}$ & $\begin{array}{l}\text { Kauri, Rimu and Totara were } \\
\text { previously used as cladding } \\
\text { timbers in NZ but are no longer } \\
\text { available }\end{array}$ & $\begin{array}{l}\text { Retrieved from Abodo (https://www.abodo. } \\
\text { co.nz/resources/articles/siberian-larch- } \\
\text { cladding-and-weatherboards-in-the-new- } \\
\text { zealand-context) on } 6 \text { May } 2020\end{array}$ & $\begin{array}{l}\text { Moderate: } \\
\text { Limited } \\
\text { NZ Supply } \\
\text { otherwise } \\
\text { imported } \\
\text { from Russia. }\end{array}$ & $\begin{array}{l}\text { - Moderate Durability } \\
\text { - Durability Class } 3 \\
\text { (https://wwww.abodo.co.nz/resources/ } \\
\text { articles/siberian-larch-cladding-and- } \\
\text { weatherboards-in-the-new-zealand- } \\
\text { context) }\end{array}$ & $\begin{array}{l}\text { - Waterproof membrane is common } \\
\text { underneath to ensure water tightness } \\
\text { - Flammable }\end{array}$ & Low \\
\hline
\end{tabular}




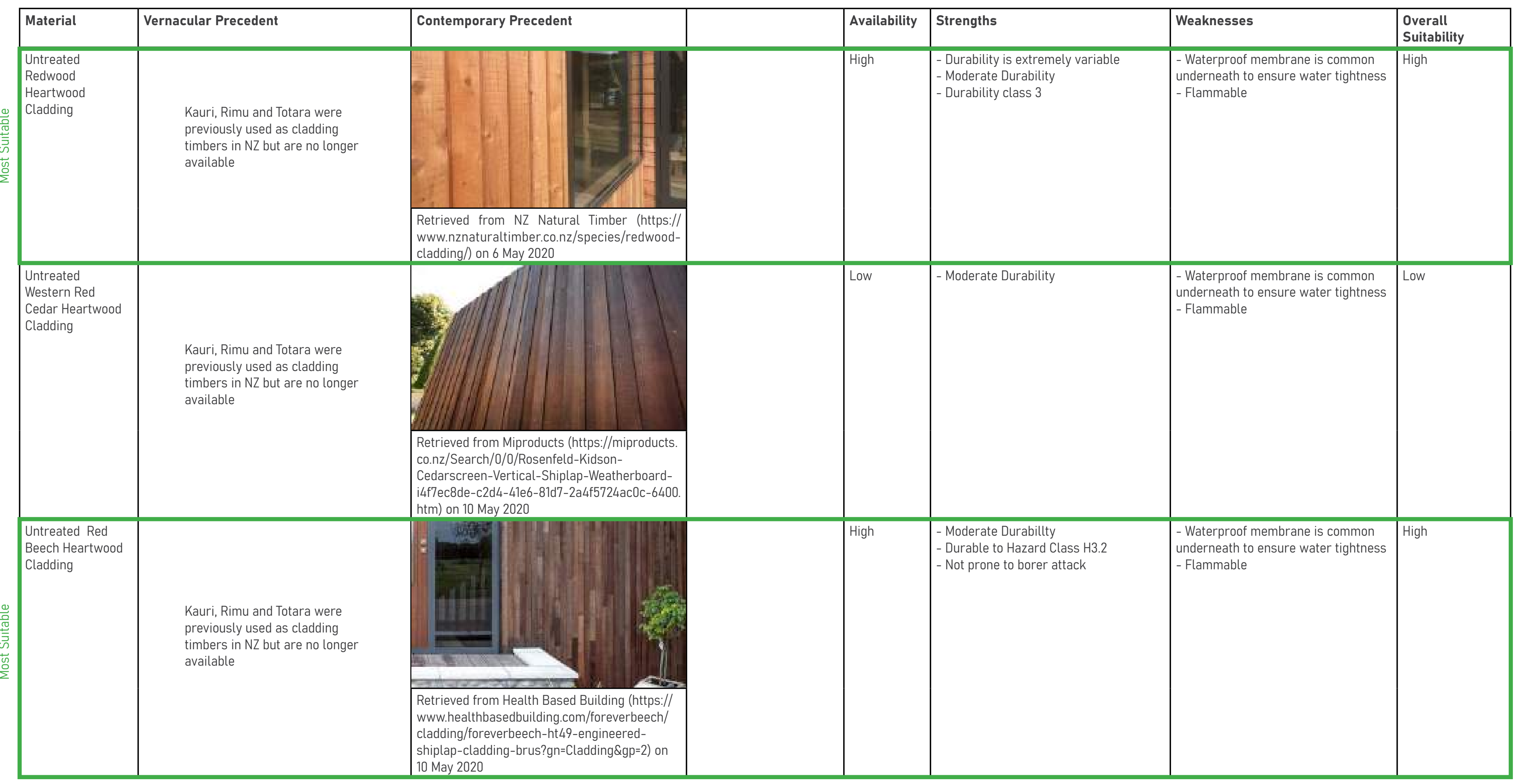




\section{Most Suitable Cladding Materials}

Clay or lime-based plaster, as well as untreated Macrocarpa, Redwood and Red Beech were found to be the rost suitable biodegradable cladling materials for New Zealand. Clay and lime-based plasters are more vapour permeable than timber claddings thus providing good dry put potent but the there is potential therefore to use both a phaster and a timber cladding over a vented cavity phold both durability and vapour permeability.

\section{Plaster}

Plastering straw bales is a traditional straw bale construction method (Racusin, 2012). Once the bales are sealed on both sides with plaster the tiny air pockets in the straw create effective insulation (Kennedy et al., 2014). The choice of plaster is crucial to ensure the bales remain dry. The main plaster types include earth, gypsum, lime and cement-based plasters although only earth and limebased plasters are biodegradable (Kennedy et al., 2014). These plasters range from weakest and most hygroscopic (the ability to absorb moisture from the air and surroundings) with earth-based plasters to the strongest and least hygroscopic with cement-based plasters. Claybased plasters are the best for straw bale walls as they are the most hygroscopic, which means that they will naturally wick moisture away from a straw bale wall, protecting it from moisture intrusion (Kennedy et al., 2014). They can absorb odours and soften sounds whilst also helping to maintain a constant and healthy humidity and indoor air quality (Racusin, 2012). The plaster also provides a layer of fire resistance (Kennedy et al., 2014).The layer of plaster

\section{Figure 33}

A selection of tiles finished with tadelakt using all New Zealand materials, 2012
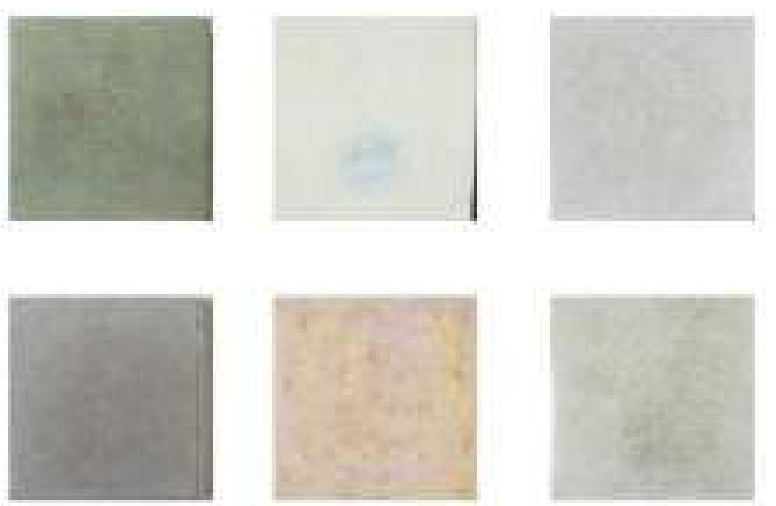

Reprinted from "Toward healthier, sustainable, medium density housing, through a return to natural materials" by S. Jaycock, 2012, Victoria University of Wellington. Copyright 2012 by Steven Jaycock on both sides of the bale wall adds structural strength and acts as bracing to resist earthquake and wind loads (Kennedy et al., 2014). Laboratory testing has shown th a well-built earth-plastered straw bale wall system can endure a very sizeable seismic event if there are strong connections between the walls, the floors and the ceiling/ roof structure (Champion, 2009; Hsiaw, 2010).

Clay-plaster is not weather resistant and will erode if not protected. Lime can be applied as a weatherproofing layer to the exterior of a building through limewash. Limewas can be made in New Zealand and can be made in many different natural colours (figure 33) (Jaycock, 2014). Lime is a natural biodegradable material as it has the same chemical make up as limestone when it is set on a building (Racusin, 2012). However, it requires an energy-intensive process to produce where the mined limestone is heated to $900^{\circ} \mathrm{C}$ to produce the quicktime power used to create lime wash (Kennedy et al., 2014; Racusin, 2012). (Scan Lime Cycle Image). Lime is exceptionally weatherproof (Kennedy et al., 2014). When it is raining, an exterior lime render will absorb moisture until saturated (Racusin 2012). This saturation prevents any further absorption of moisture, and the lime surface will repel water until the humidity level drops again, protecting the wall behin it (Racusin, 2012). Lime is also breathable and water permeable, allowing moisture in the clay-plaster beneath to evaporate into the outside air (Kennedy et al., 2014). It also regulates humidity by absorbing excess moisture from the environment, then releasing it as humidity drops (Kennedy et al., 2014). This makes lime ideal for interio surfaces in wet and humid areas such as kitchens and bathrooms (Kennedy et al., 2014). Lime is also physically flexible making it a suitable choice in seismically acti

\section{Timber}

As of 2017, timber weatherboards have been the most popular cladding material in New Zealand (Brunsdon \& Magan, 2017). Timber cladding is also used in straw bale construction (Kennedy et al., 2014; Racusin, 2012). Locally grown redwood, Red Beech and Macrocarpa are durable species that can be left untreated as cladding materials (T. leaving aesthetics as the only criteria for selection.

\subsection{Foundations}

Biodegradable Foundations

Performance Requirements

- The NZBC B2 requires foundations to last the life time of the building but at least 50 years Connect the building securely to the ground

Dissipate loads into the ground

E233 Walls floors, and structural elements in contact with, or in close proximity to the ground must not absorb or transmit moisture in quantities that could cause undue dampness, damage to building elements, or both.

\begin{tabular}{|c|c|c|c|}
\hline Material & Image & Availability & Overall Suitability \\
\hline $\begin{array}{l}\text { Untreated Durable Timber } \\
\text { Heartwood Piles } \\
\text { (Totara has a history of use in NZ) }\end{array}$ & & Moderate & Low \\
\hline \multicolumn{4}{|l|}{$\begin{array}{l}\text { Reprinted from "Stable } \\
\text { Foundations" by N. Isaacs, 2009, } \\
\text { BRANZ. Copyright } 2009 \text { by Nigel } \\
\text { Isaacs. }\end{array}$} \\
\hline $\begin{array}{l}\text { Untreated Durable Timber } \\
\text { Heartwood Post and Beam on } \\
\text { Gravel Bed }\end{array}$ & & Moderate & Low \\
\hline \multicolumn{4}{|l|}{$\begin{array}{l}\text { Reprinted from "The Art of Natural } \\
\text { Building-Second Edition" by J. } \\
\text { Kennedy, 2014, Copyright } 2014 \text { by } \\
\text { Joseph Kennedy. }\end{array}$} \\
\hline $\begin{array}{l}\text { Untreated Durable Timber } \\
\text { Heartwood Post and Beam on } \\
\text { Grade }\end{array}$ & & Moderate & Low \\
\hline \multicolumn{4}{|l|}{$\begin{array}{l}\text { Retrieved from Detail (https:// } \\
\text { www.detail.de/artikel/ } \\
\text { strohboid-klimafreundliches- } \\
\text { strohhaus-34813/) on } 17 \text { April } \\
\text { 2020. Last Updated } 17 \text { October } \\
\text { 2019. }\end{array}$} \\
\hline Earth Bag Foundation & & Moderate & Low \\
\hline \multicolumn{4}{|l|}{$\begin{array}{l}\text { Reprinted from "The Art of Natural } \\
\text { Building-Second Edition" by J. } \\
\text { Kennedy, 2014, Copyright } 2014 \text { by } \\
\text { Joseph Kennedy. }\end{array}$} \\
\hline $\begin{array}{l}\text { Cork Bock Foundation (has } \\
\text { only been used in small scale } \\
\text { experiments) }\end{array}$ & & Low & Low \\
\hline $\begin{array}{l}\text { Retrieved from Studio Bark (https:// } \\
\text { studiobark.co.uk/buildings-can- } \\
\text { be-made-of-solid-cork-we-built- } \\
\text { this-to-prove-it/) on } 20 \text { May } 2020 .\end{array}$ & & & \\
\hline
\end{tabular}




\begin{tabular}{|c|c|c|c|}
\hline Material & Image & Availability & Overall Suitability \\
\hline Stone Footings & & Moderate & Moderate \\
\hline $\begin{array}{l}\text { Reprinted from "Stable } \\
\text { Foundations" by N. Isaacs, 2009, } \\
\text { BRANZ. Copyright } 2009 \text { by Nigel } \\
\text { Isaacs. }\end{array}$ & & & \\
\hline Precast Concrete Footings & & High & High \\
\hline $\begin{array}{l}\text { Reprinted from "Lightweight } \\
\text { Recoverable Foundations on } \\
\text { Suitable Ground", 2015, Green } \\
\text { Building Council España. Copyright } \\
2015 \text { by Llorens Duran \& Pujadas } \\
\text { Gispert. }\end{array}$ & & & \\
\hline Precast Concrete Piles & & High & High \\
\hline $\begin{array}{l}\text { Reprinted from "Lightweight } \\
\text { Recoverable Foundations on } \\
\text { Suitable Ground", 2015, Green } \\
\text { Building Council España. Copyright } \\
2015 \text { by Llorens Duran \& Pujadas } \\
\text { Gispert. }\end{array}$ & & & \\
\hline Precast Concrete Strip Foundations & & High & High \\
\hline $\begin{array}{l}\text { Reprinted from "Lightweight } \\
\text { Recoverable Foundations on } \\
\text { Suitable Ground", 2015, Green } \\
\text { Building Council España. Copyright } \\
2015 \text { by Llorens Duran \& Pujadas } \\
\text { Gispert. }\end{array}$ & & & \\
\hline Steel Screw Piles & & High & High \\
\hline $\begin{array}{l}\text { Reprinted from "Lightweight } \\
\text { Recoverable Foundations on } \\
\text { Suitable Ground", 2015, Green } \\
\text { Building Council España. Copyright } \\
2015 \text { by Llorens Duran \& Pujadas } \\
\text { Gispert. }\end{array}$ & & & \\
\hline
\end{tabular}

Performance requirement E2.3.3 from clause E2 of the NZBC states that "walls, loors, and structural elements in contact with, or in close proximity to, the ground must not absorb or transmil moisture in quantiles that could cause undue damphess, damage to bulding elements, or both.

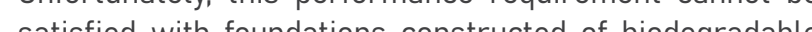
satisfied with found

It is simply not wise to construct a building component as crucial as foundations out of a biodegradable material when it is in contact with the ground. The foundation will begin to biodegrade and severely compromise the stability of the structure. Untreated Totara piles have previously been used as foundations in New Zealand, but parts of begin to noticeably sink over time as the piles slowly rotted (Isaacs, 2009). Isaacs shares in his paper, "Stable Foundations" that floors in parts of a $1908 \mathrm{New}$ Zealand house on a relatively dry site sank over 90 years until the bottom of the laundry floor joists touched the ground (lsaacs, 2007). Alhough foundations constructed of biodegradable materials such as timber have served his nation and the rest of humanity well for durability is expected.

Reusable but non-biodegradable foundations such as precast concrete foundations can satisfy the NZBC's stringent performance requirements whilst maintaining the zero-waste objective. Precast concrete footings, piles astrip foundations, as well as steel screw piles, are al durable reusable zero waste foundation options for $\mathrm{New}$ Zealand. 


\subsection{Flooring}

AVAILABILITY KEY

High=Produced in NZ

Moderate- Raw materials present in NZ

Low $=$ Imported product

-Under the NZBC B2, Floors must last at least 50 years

Provide habitable platform

Perform under dead and live load

\begin{tabular}{|c|c|c|c|c|c|c|}
\hline Material & Image & Image Source & Availability & Strengths & Weaknesses & \begin{tabular}{|l|} 
Overall \\
Suitability
\end{tabular} \\
\hline $\begin{array}{l}\text { Untreated Matia } \\
\text { Heartwood } \\
\text { Flooring }\end{array}$ & & $\begin{array}{l}\text { Retrieved from Saw Mill Direct (https:// } \\
\text { sawmilldirect.co.nz/category/matai- } \\
\text { flooring/) on } 4 \text { May } 2020 \text {. }\end{array}$ & High & $\begin{array}{l}\text { - High dimensional stability and } \\
\text { hardness make it excellent as a floor } \\
\text { - Durability equivalent to Hazard Class } \\
\text { of H3.1 } \\
\text { - Light } \\
\text { - Suitable for suspended and inter- } \\
\text { storey floors }\end{array}$ & $\begin{array}{l}\text { - Poor Insulation } \\
\text { - Poor thermal mass } \\
\text { - Flammable }\end{array}$ & High \\
\hline $\begin{array}{l}\text { Untreated } \\
\text { DouglasFir } \\
\text { Heartwood } \\
\text { Flooring }\end{array}$ & & $\begin{array}{l}\text { Retrieved from Pinterst (https://www. } \\
\text { pinterest.nz/pin/434034482809088328/) } \\
\text { on } 4 \text { May } 2020 .\end{array}$ & $\begin{array}{l}\text { High: } \\
\text { Available by special } \\
\text { order in NZ }\end{array}$ & $\begin{array}{l}\text { - Moderate durability } \\
\text { - 20-30 life span without weather } \\
\text { exposure } \\
\text { - Light } \\
\text { - Suitable for suspended and inter- } \\
\text { storey floors }\end{array}$ & $\begin{array}{l}\text { - Poor Insulation } \\
\text { - Poor thermal mass } \\
\text { - Flammable }\end{array}$ & Moderate \\
\hline $\begin{array}{l}\text { Untreated } \\
\text { Macrocarpa } \\
\text { Heartwood } \\
\text { Flooring }\end{array}$ & & $\begin{array}{l}\text { Retrieved from Pankhurst Saw Milling } \\
\text { (https://pankhurstsawmilling.co.nz/ } \\
\text { macrocarpa/) on } 4 \text { May } 2020 \text {. }\end{array}$ & High & $\begin{array}{l}\text { - Moderate durability } \\
\text { - Will last } 40-60 \text { years without weather } \\
\text { exposure } \\
\text { - Naturally borer resistant } \\
\text { - Light } \\
\text { - Suitable for suspended and inter- } \\
\text { storey floors }\end{array}$ & $\begin{array}{l}\text { - Poor Insulation } \\
\text { - Poor thermal mass } \\
\text { - Flammable }\end{array}$ & High \\
\hline $\begin{array}{l}\text { Rammed Earth } \\
\text { Floor }\end{array}$ & & $\begin{array}{l}\text { Retrieved from Earth Studio (http:// } \\
\text { earthstudio.co.nz/rammed-earth- } \\
\text { floors/) on } 4 \text { May } 2020 \text {. }\end{array}$ & $\begin{array}{l}\text { High: } \\
\text { Produced in NZ by } \\
\text { Earth Studio }\end{array}$ & $\begin{array}{l}\text { - High durability when sealed with } \\
\text { natural oil and wax } \\
\text { - High thermal mass } \\
\text { - non-flammable }\end{array}$ & $\begin{array}{l}\text { - Heavy } \\
\text { - Only suitable for groud floors } \\
\text { - Poor insulation as a isolated } \\
\text { component }\end{array}$ & Moderate \\
\hline
\end{tabular}




\begin{tabular}{|c|c|c|c|c|c|c|}
\hline Material & Image & Image Source & Availability & Strengths & Weaknesses & \begin{tabular}{|l|} 
Overall \\
Suitability
\end{tabular} \\
\hline $\begin{array}{l}\text { Untreated Rimu } \\
\text { Heartwood } \\
\text { Flooring }\end{array}$ & & $\begin{array}{l}\text { Retrieved from NZ natural Timber } \\
\text { (https://www.nznaturaltimber.co.nz/ } \\
\text { species/rimu/) on } 4 \text { May 2020. }\end{array}$ & High & $\begin{array}{l}\text { - Moderately durable } \\
\text { - Durability Class } 3 \\
\text { - Light } \\
\text { - Suitable for suspended and inter- } \\
\text { storey floors }\end{array}$ & $\begin{array}{l}\text { - Susceptible to borer attack } \\
\text { - Poor Insulation } \\
\text { - Poor thermal mass } \\
\text { - Flammable }\end{array}$ & Moderate \\
\hline $\begin{array}{l}\text { Untreated } \\
\text { Siberian Larch } \\
\text { Heartwood } \\
\text { Flooring }\end{array}$ & & $\begin{array}{l}\text { Retrieved from Siberian Larch Wood } \\
\text { (https://www.siberianlarchwood.co.nz/ } \\
\text { gallery) on } 4 \text { May } 2020 .\end{array}$ & \begin{tabular}{|l|} 
Low: \\
Imported from Russia
\end{tabular} & $\begin{array}{l}\text { - Moderate durability } \\
\text { - Durabiltiy Class } 3 \\
\text { - Light } \\
\text { - Suitable for suspended and inter- } \\
\text { storey floors }\end{array}$ & $\begin{array}{l}\text { - Poor Insulation } \\
\text { - Poor thermal mass } \\
\text { - Flammable }\end{array}$ & Low \\
\hline $\begin{array}{l}\text { Untreated Tawa } \\
\text { Heartwood } \\
\text { Flooring }\end{array}$ & & $\begin{array}{l}\text { Retrieved from NZ natural Timber } \\
\text { (https://www.nznaturaltimber.co.nz/ } \\
\text { species/nz-tawa/) on } 4 \text { May } 2020 .\end{array}$ & High & $\begin{array}{l}\text { - Non-durable } \\
\text { - Light } \\
\text { - Suitable for suspended and inter- } \\
\text { storey floors }\end{array}$ & $\begin{array}{l}\text { - Poor Insulation } \\
\text { - Poor thermal mass } \\
\text { - Flammable }\end{array}$ & Low \\
\hline $\begin{array}{l}\text { Untreated Red } \\
\text { Beech Heartwood } \\
\text { Flooring }\end{array}$ & & $\begin{array}{l}\text { Retrieved from NZ natural Timber } \\
\text { (https://www.nznaturaltimber.co.nz/ } \\
\text { species/nz-beech/) on } 4 \text { May 2020. }\end{array}$ & High & $\begin{array}{l}\text { - Moderately durable } \\
\text { - Durable equivalent to Hazard Class } 3.2 \\
\text { - Not prone to borer attack } \\
\text { - Light } \\
\text { - Suitable for suspended and inter- } \\
\text { storey floors }\end{array}$ & $\begin{array}{l}\text { - Poor Insulation } \\
\text { - Poor thermal mass } \\
\text { - Flammable }\end{array}$ & High \\
\hline
\end{tabular}




\subsection{Roofing}

\section{Performance Requirements}

-Under the NZBC B2, Roofing must last at least 15 years though the roof structure must last for 50

- Divert rain water away from the building

Ensure Airtightness

bulling elements, or both.

\begin{tabular}{|c|c|c|c|c|c|c|}
\hline Material & Vernacular Precedent & Contemporary Precedent & Availability & Strengths & Weaknesses & $\begin{array}{l}\text { Overall } \\
\text { Suitability }\end{array}$ \\
\hline Thatch & $\begin{array}{l}\text { Thatch Roof, Esk Homestead, Canterbury, New } \\
\text { Zealand, } 1864 \\
\text { Photograph by Min Hall, 208. Reprinted from } \\
\text { "Earth and Straw Bale: An investigation of their } \\
\text { performance and potential } \\
\text { as building materials in New Zealand" by M. Hall, } \\
\text { 2012, Victoria University of Wellington. Copyright } \\
2012 \text { by Min Hall. }\end{array}$ & $\begin{array}{l}\text { Photograph by Damir Fabijanic, 2014. Retrieved } \\
\text { from Detail (https://www.detail.de/blog-artikel/ } \\
\text { ein-material-fuenf-pyramiden-cork-house-von- } \\
\text { matthew-barnett-howland-34518/) on } 17 \text { April } \\
\text { 2020. Last updated } 19 \text { August 2019. } \\
\end{array}$ & Moderate & $\begin{array}{l}\text { - Provides some additional insulation if } \\
\text { airtight }\end{array}$ & $\begin{array}{l}\text { - Poor Durability } \\
\text { - Requires waterproof membrane for } \\
\text { water tightness }\end{array}$ & Low \\
\hline Cork Panel & $\begin{array}{l}\text { No Vernacular } \\
\text { Example }\end{array}$ & $\begin{array}{l}\text { Retrived from NY Times (https://www.nytimes. } \\
\text { com/2019/04/26/realestate/building-with-cork- } \\
\text { sustainable-architecture.html) on } 13 \text { May } 2020\end{array}$ & Low & $\begin{array}{l}\text { - Moderate-high durability } \\
\text { - Water resistant } \\
\text { - Fire resistant } \\
\text { - provides additional insulation }\end{array}$ & $\begin{array}{l}\text { - Requires waterproof membrane for } \\
\text { water tightness }\end{array}$ & Low \\
\hline Earth & $\begin{array}{l}\text { Mugsum Mud Huts, Cameroon. } \\
\text { Retrieved from Design boom (https://www. } \\
\text { designboom.com/architecture/musgum-earth- } \\
\text { architecture/) on } 17 \text { April } 2020 \text {. }\end{array}$ & $\begin{array}{l}\text { No Contemporary } \\
\text { Example }\end{array}$ & Moderate & - Provides thermal mass & $\begin{array}{l}\text { - Poor durability } \\
\text { - Poor insulation }\end{array}$ & Low \\
\hline Seaweed & $\begin{array}{l}\text { Note. House with seaweed roof made using eelgrass } \\
\text { from the ocean that is able to withstand decay } \\
\text { for hundreds of years, retrieved from Archdaily } \\
\text { (https://www.archdaily.com/805415/11-vernacular- } \\
\text { building-techniques-that-are-disappearing) on } 17 \\
\text { April 2020. Last updated in 2017. }\end{array}$ & $\begin{array}{l}\text { Retrived from Pinterest (https://www.pinterest.nz/ } \\
\text { pin/505740233152269555/) on } 13 \text { May } 2020\end{array}$ & Moderate & $\begin{array}{l}\text { - Provides some additional insulation if } \\
\text { airtight }\end{array}$ & $\begin{array}{l}\text { - Poor durability } \\
\text { - Requires waterproof membrane for } \\
\text { water tightness }\end{array}$ & Low \\
\hline
\end{tabular}




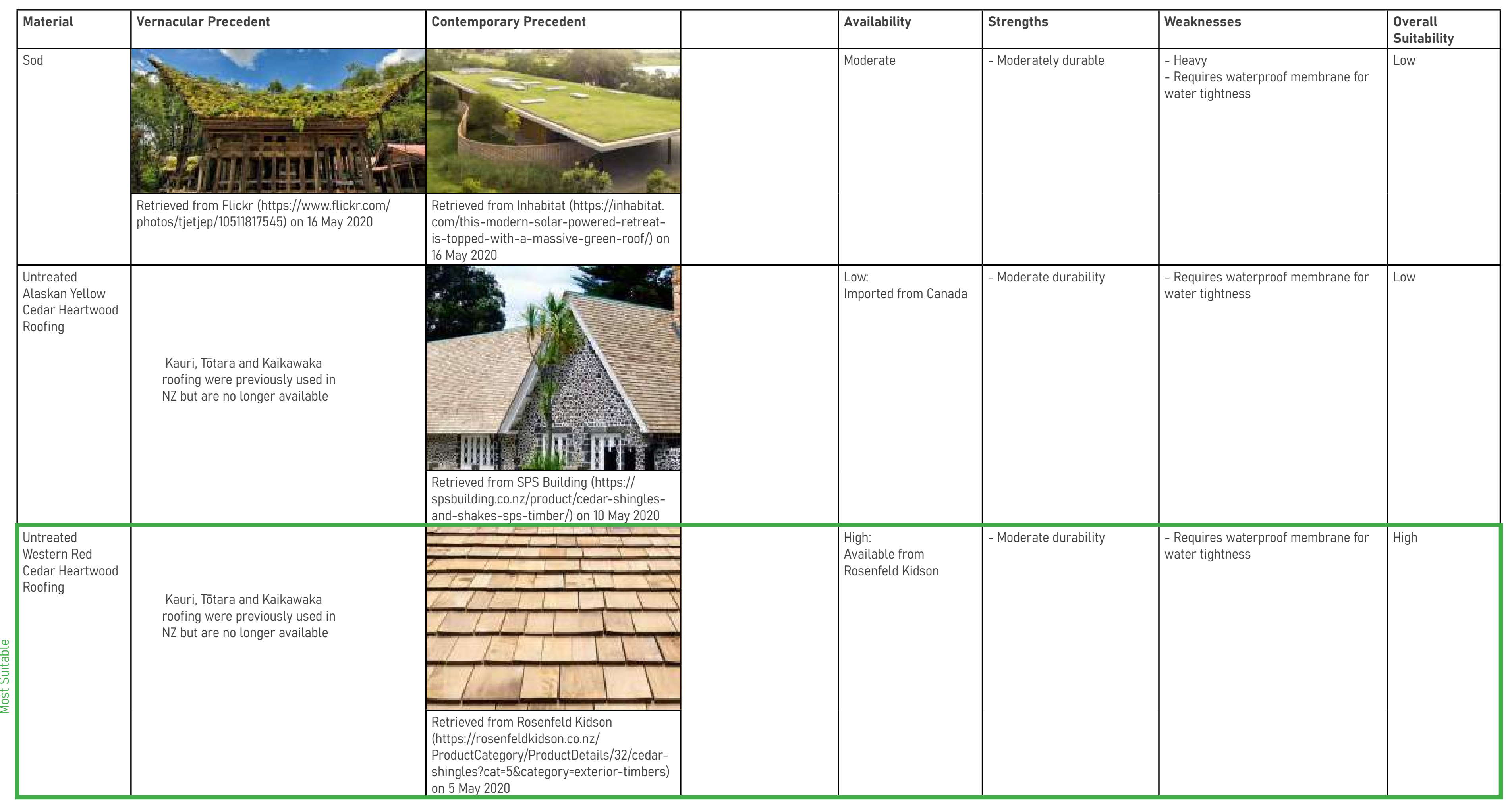




\section{Timber Roofing}

Untreated Western Red cedar shingles or shakes were found to be the most suitable biodegradable roofing material for New Zealand. Timber is the most durable biodegradable roofing material and Western Red cedar is and shakes produced here in New Zealand. Timber shingles Zealand for around 200 years (BRANZ, 2020a). Shingles are sawn and have relatively smooth faces while Shakes are usually hand split (although some are also sawn) and usually have a rougher textured surface on at least one side (BRANZ, 2020a). Both shakes and shingles have random widths and also taper in thickness (BRANZ, 2020a). Timber shingles and shakes are not covered by

\subsection{Summary of Zero Waste Materials for NZ}
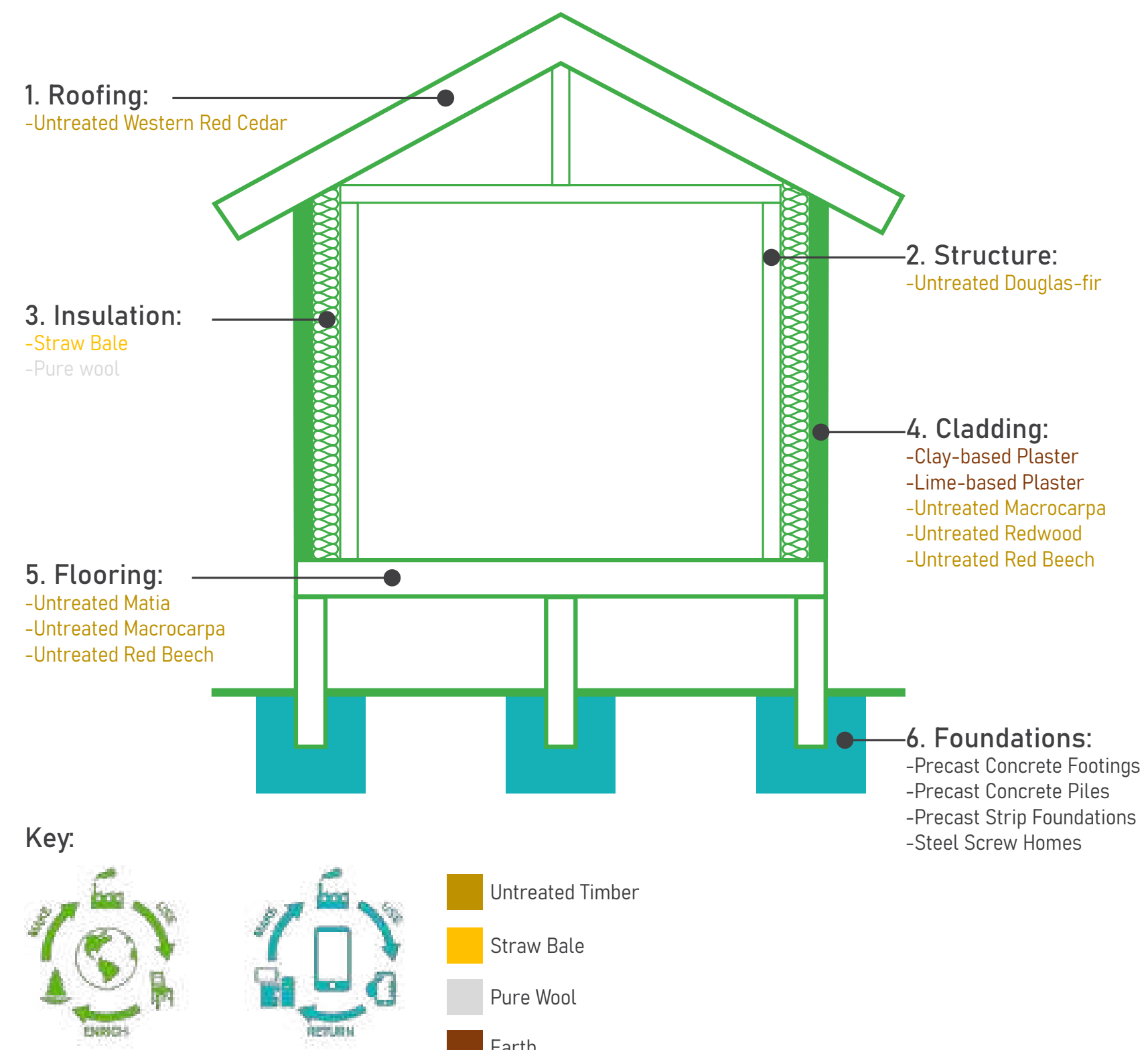

BO-SPHERE

TECH-SPHERE so they need to be consented as an Alternative Solution (BRANZ, 2020a). Western red cedar or Alaskan yellow cedar that is grown and processed in Canada represent 列 installed in New Zealand (BRANZ, 2020a). However, previously, redwood shingles and shakes were sometimes used (BRANZ, 2020a). Historically, New Zealand kauri, totara and kaikawaka timbers were used by European settlers for shingles or shakes, but these timbers are manufacture (BRANZ, 2020a)
New Zealand Building Code Acceptable Solution E2/ASI,

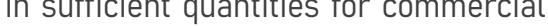

\subsection{Biosphere Barriers}

The majority of barriers limiting the uptake of biodegradable building materials stem from their decreased durability in the presence of moisture. This is because moisture is a catalyst of the biodegradation process.

\section{Building Regulations}

Fortunately, there are no barriers that directly prevent the use of biodegradable building materials in New Zealand. The durability requirements in clause $B 2$ and the moisture resistance requirements in E2 of the NZBC do prevent some of the less durable biodegradable construction techniques found in vernacular architecture such as Raupo techniques found invernacular architecture such as Raupo huts, untreated timber ples or entirely earth structures. But so many more sumicienty durable biodegradable construction methods exist that can be used. In fact, our pertor tha werconed given they can be proven to perform.

\section{Perceived Low Durability}

Amongst the general public the word biodegradable can cause concern when associated with building materials as people fear it means their house will rot away. In truth however, just because biodegradable materials can biodegrade does not mean they will. Biodegradation requires specific environmental conditions such as moisture and bacterial surroundings which can easily be denied while the material carries out its operational life. Biodegradable construction can last for centuries and in many caseslast longer than our modern-day constructions: certainty, longer than the arbitrary mandated 50-year lifespan mandated in B2 of the NZBC. The Lavenham Guildhall in Sudbury England, for example, is built out of exposed

\section{Figure 34}

Lavenham Guildhall, Sudbury, England

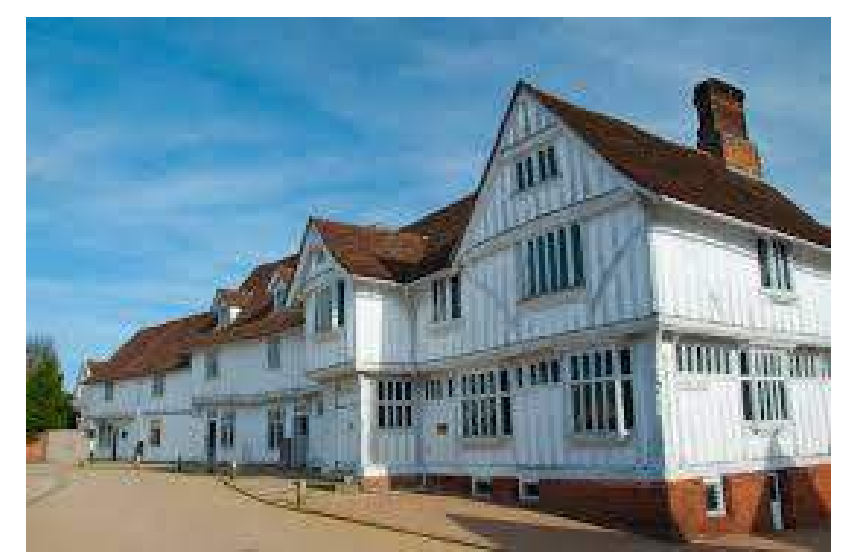

Retrieved from Britain Express (https://www britainexpress.com/attractions.htm?attraction=3663) untreated timber and coated once every five years with limewash (figure 34). This building was built in 1529 nearly 500 years ago, and is still in everyday use. Our oldest known earth building 1 (fig Zealand is Pompaltier twouse, in Russell bult in 1841 (igure 35). This building is country's climate and withstood many earthquakes.

Figure 35

Pompallier House, Russell, New Zealand

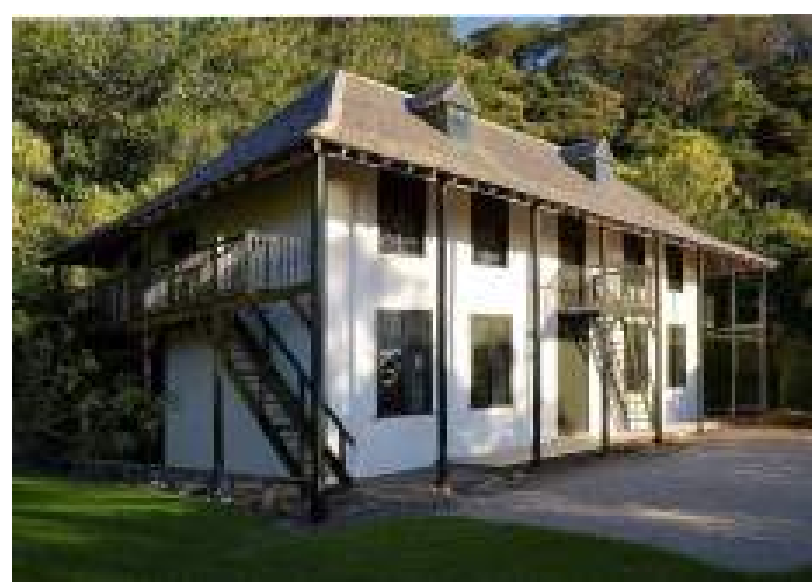

Retrieved from NZ Herald (https://www.nzherald.co.nz/ travel/news/article.cfm?__id=7\&objectid=11113338)

Biodegradable Insulation

Inorganic insulation materials dominate the NZ market Fiberglass wall insulation occupies $90 \%$ of the market and the other share is mainly polyester insulation (Brunsdon \& Magan, 2017). However, overseas in countries like Germany, organic wall insulation materials such as wood fibre, cellulose, hemp, flax, straw or wool are not uncommon, occupying up to $4 \%$ of the market (Götze \& Naderer, 2019). Straw bale and wool are the only biobased insulation materials produced here and represent an insignificant share of the New Zealand marke (mowever, as recently as 2008 blownproduced in NZ (McChed paper) insulation was being based insulation materials continue to battle building regulations around the world as they are deemed to have inferior durability due to their lack of moisture resistance (Sigmund, 2017). This is especially the mindset of the New Zealand construction industry following the leaky building crisis. However, thorough hygrothermal testing out of Germany over the last 10 years in the "11th edition of the FNR market overview of insulating materials" has shown these reservations unfounded (Kaiser et al., 2020). 


\section{Construction Approach \\ Exploration} Timber, being a natural biodegradable material will begin Inorganic building wraps and membranes that keep a building watertight and/or airtight are one the most challenging aspects to find a biodegradable or even reusable solution for especially for roof construction. White the NZBC does not demand the use of a waterproof roofing membrane it does require that bullding materials and components are durable and that external water is managed so it does not damage the structural integrity Pringle 2013) This is certainty difficult to occupants (T. Pringle, 2013). This is certainly diffich to onsure without a water Homestead (figure 36) in North Canterbury buitt in 1864

Figure 36

Esk Head Homestead, North Canterbury, 1864

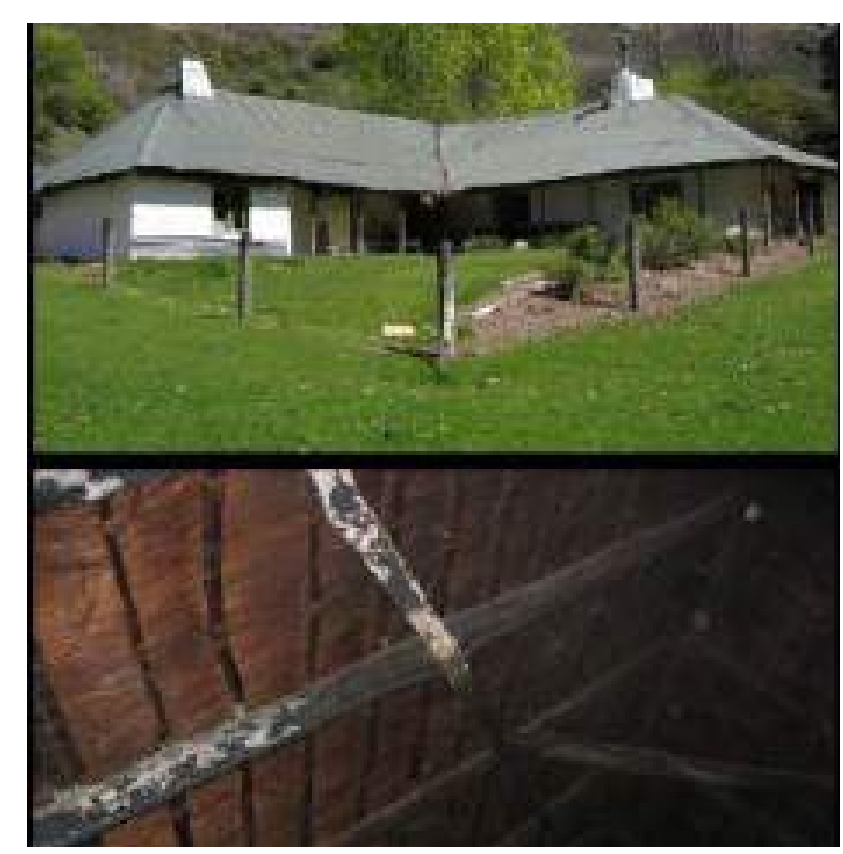

Photograph by Min Hall, 208. Reprinted from "Earth and Straw Bale: An investigation of their performance and Straw Bale:
potential

as building materials in New Zealand" by M. Hall, 2012 Victoria University of Wellington. Copyright 2012 by Min Hall.

is an example of how a watertight roof was constructed in New Zealand with biodegradable thatching before the invention of synthetic membranes and wraps. This biodegradable construction has lasted for nearly 150 years demonstrating the durability and longevity possible with a biodegradable roof construction. A watertight biodegradable roof construction without a membrane is therefore possible and is pursued in this thesis (see page 156).

instead of keeping the timber dry or able to dry out, chemical treatment is used in New Zealand to increase the moisture resistance of the timber and hinder the

Wet boric or boron salts timber treatments were first introduced in New Zealand in 1952 (BRANZ, 2013). Before that, untreated native timbers such as Rimu, Matia and Totara and some untreated radiata pine framing were used (BRANZ, 2013). From 2003 there was a period where all timber needed to be treated in New Zealand (T. Pringle 2012). However, today, for some applications, NZS 3602:2003 lists a limited number of species that are considered durable enough to meet the requirements of the Building Code without the need for treatment such as macrocarpa, redwood and western red cedar externally and Douglasfir, macrocarpa, rimu and matai internally (BRANZ, 2020b). Despite the slight loosening of restrictions around the of timber still dominates the industry in New Zealand.

Not only does chemical treatment of timber inhibit the biodegradation process but it also makes the timber inappropriate for reuse in domestic construction (Rhodes \& Dolan, 2013). This results in our country's greatest biodegradable asset and the majorty of our residentia construction ending up in the landfill at the end of its life. When landflled the chemicals also damage surrounding (Parisio, 2006). ponter contaninate groundwate (Parisio, 2006)

Cost

Unlike timber, the biodegradable materials of straw bale, clay-plaster and pure wool insulation are not conventiona New Zealand construction materials. This often means higher cost. The cost of straw bales as a raw material, for example, is low, however, the unfamiliarity of the material makes it difficult to get competitive prices from builders (Hall, 2012). In addition, construction with in- situ straw bale and clay plaster is labour intensive (Hall, 2012 Kennedy et al., 2014, Racusin, 2012). Unless the owner builds the dwelling themsetves a straw bale house will unlikely be cheaper than a conventional New Zealand for more , 2012). The cost is also nicreased by the need walls (Hall, 2012).

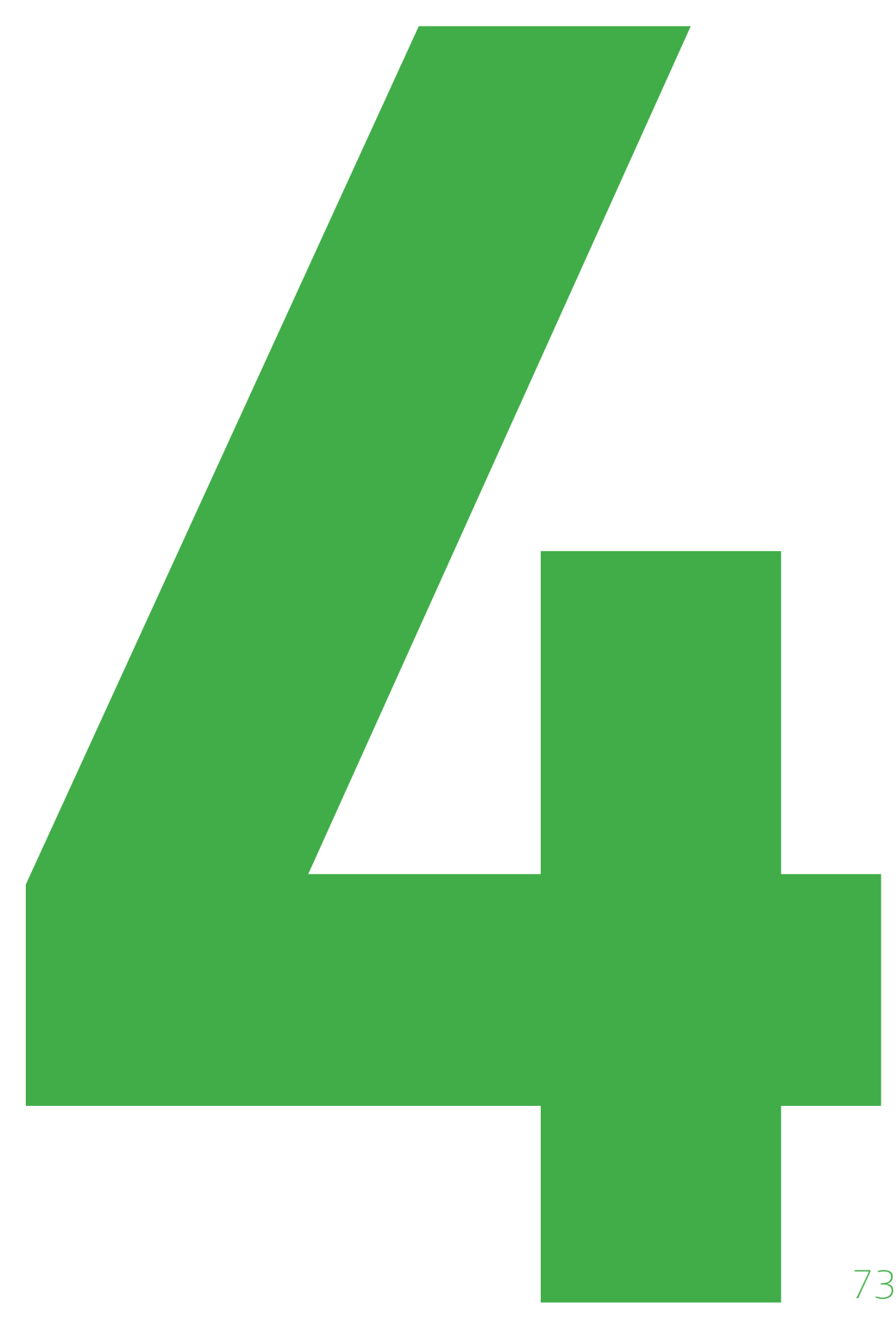


This chapter contributes towards the third thesis objective of finding the optimum biodegradable construction approach for New Zealand. In this chapter. construction approaches of in-situ construction, standard suitable for bioderadable whe suitable fod to deterials for New 7 and found in the previous chapter are used to explore these construction approaches. For each approach precedents are analysed prior to the production of design proposals. The metrics of weight thermal resistance and vapour resistance are used to compare design proposals for each construction approach. Data was sourced on the materials used in the proposed designs to calculate these metrics

\section{Properties of Materials}

\begin{tabular}{|c|c|c|c|}
\hline Material & Density & Thermal conductivities & Vapour resistivities \\
\hline Straw bale & 128 Kg/m3 (Magwood, 2016) & $\begin{array}{l}0.085 \text { W/mk (calculated } \\
\text { from Hall, 2019) }\end{array}$ & $\begin{array}{l}9.71 \mathrm{MNs} / \mathrm{gm} \text { (calculated } \\
\text { from (Magwood, 2016) }\end{array}$ \\
\hline Straw (Ecococon) & $110 \mathrm{Kg} / \mathrm{m} 3$ (Ecococon, 2017) & $\begin{array}{l}0.0494 \text { W/mk (calculated } \\
\text { from Ecococon, 2017) }\end{array}$ & $\begin{array}{l}\text { Straw bale: } 9.71 \mathrm{MNs} / \mathrm{gm} \\
\text { (calculated from Magwood, } \\
\text { 2016) }\end{array}$ \\
\hline Pure wool insulation & 25 Kg/m3 (Tuzcu, 2007) & 0.033 W/mk (Tuzcu, 2007) & $\begin{array}{l}10.0 \mathrm{MNs} / \mathrm{gm} \text { (Black Mountain } \\
\text { Insulation, 2020) }\end{array}$ \\
\hline Douglas-fir & $\begin{array}{l}462 \mathrm{Kg} / \mathrm{m} 3 \text { (Kimberley et } \\
\text { al., 2017) }\end{array}$ & $\begin{array}{l}0.12 \mathrm{~W} / \mathrm{mk} \text { (TenWolde et al., } \\
1988 \text { ) }\end{array}$ & $\begin{array}{l}541.1 \mathrm{MNs} / \mathrm{gm} \text { (calculated } \\
\text { from Kordziel et al., 2020) } \\
\end{array}$ \\
\hline Clay plaster & $\begin{array}{l}1500 \mathrm{Kg} / \mathrm{m} 3 \text { (Morton et al., } \\
2005 \text { ) }\end{array}$ & $\begin{array}{l}0.66 \mathrm{~W} / \mathrm{mk} \text { (Morton et al., } \\
\text { 2005) }\end{array}$ & $\begin{array}{l}26.3 \mathrm{MNs} / \mathrm{gm} \text { (Vares et al., } \\
\text { 2017) }\end{array}$ \\
\hline $\begin{array}{l}12.7 \mathrm{~mm} \text { Exterior gypsum } \\
\text { sheathing (DensGlass }{ }^{\circledR} \text { ) }\end{array}$ & \begin{tabular}{|l}
$708.7 \mathrm{Kg} / \mathrm{m} 3$ (DensGlass ${ }^{\circledR}$, \\
2017 )
\end{tabular} & $\begin{array}{l}0.128 \mathrm{~W} / \mathrm{mk} \text { (DensGlass }{ }^{\circledR}, \\
2017)\end{array}$ & $\begin{array}{l}60.6 \text { MNs/gm (DensGlass }{ }^{\circledR} \text {, } \\
2017 \text { ) }\end{array}$ \\
\hline $\begin{array}{llr}13 \mathrm{~mm} & \text { Interior } & \text { gypsum } \\
\text { sheathing (SHEETROCK® HD) }\end{array}$ & $\begin{array}{l}654 \mathrm{Kg} / \mathrm{m} 3 \text { (USG Boral, } \\
2019)\end{array}$ & $\begin{array}{l}0.178 \text { W/mk (USG Boral, } \\
\text { 2019) }\end{array}$ & 38.5 MNs/gm (Overton, 2015) \\
\hline
\end{tabular}

\subsection{In-situ Construction}

In-situ construction is the most common construction approach in the residential sector in New Zealand. It has been the only method of construction before the introduction of prefabricated construction. In-situ construction is the process of assenting building components on site. All construction will be in-situ to some extent but in this case, it refers to the process of building where all construction occurs on site.

\section{Precedent Review}

There are already established in-situ construction methods using the biodegradable materials found to be most suitable to New Zealand in the tradition of straw bale construction. Straw bale construction uses straw bale, clay plaster, and timber, which are all biodegradable materials suitable to New Zealand. Pure wool insulation is not a material used in straw bale construction but in-situ constructions including wool insulation can be informed by straw bale construction techniques. 


\section{Bale Infill techniques}

\section{Figure 37}

Bale infill with plastered exterior

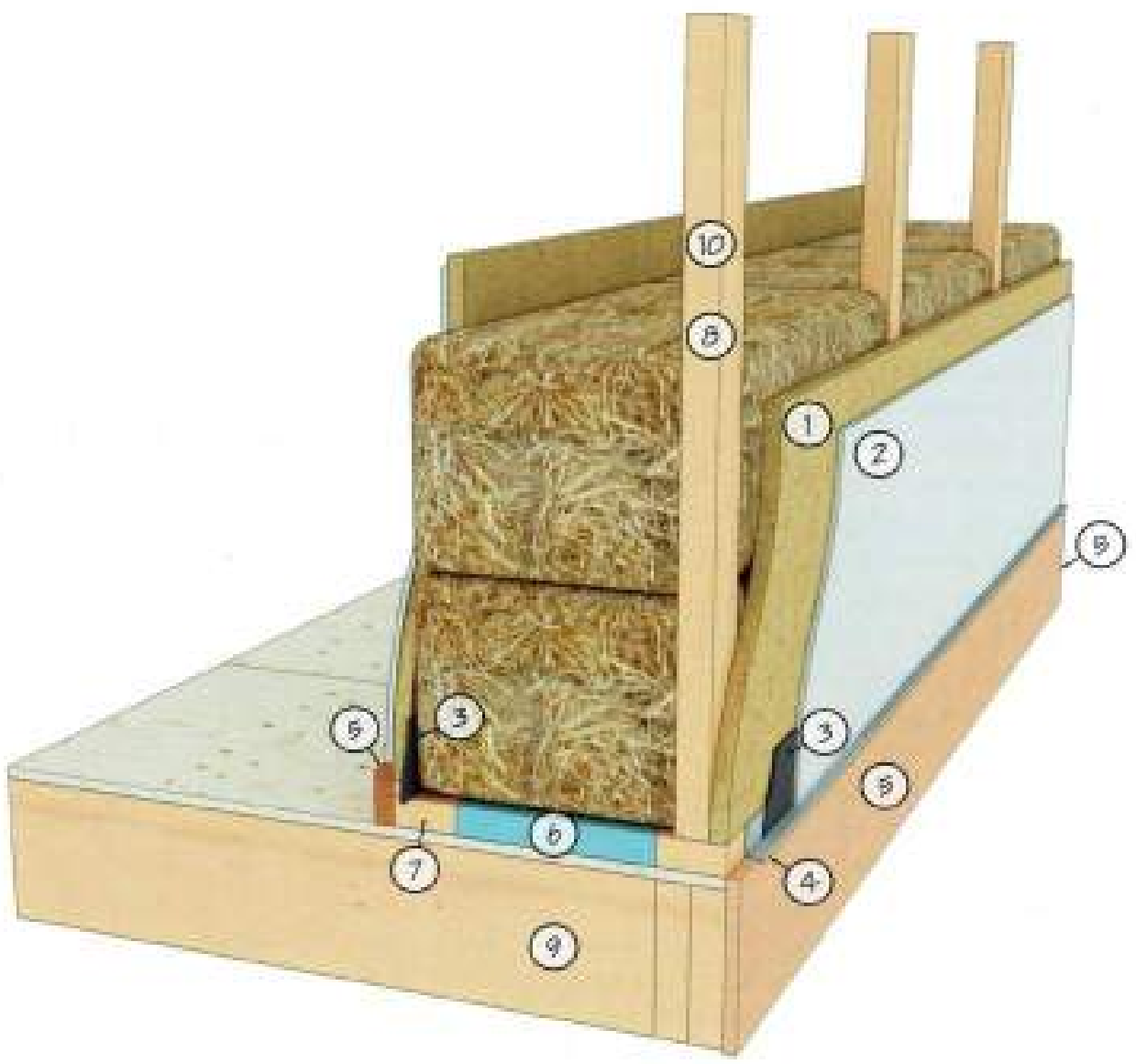

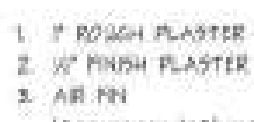

$$
\begin{aligned}
& \text { 4. MataL Fiasiesth }
\end{aligned}
$$

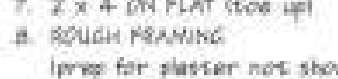

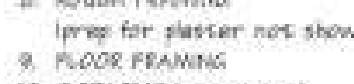

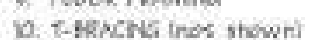

Reprinted from "The natural building companion : a comprehensive guide to integrative design and construction" by J.

\begin{tabular}{|c|c|c|}
\hline Description & Strengths & Weaknesses \\
\hline $\begin{array}{l}\text { The structural stud are spaced } \\
\text { such that a bale can be notched to } \\
\text { fit cleanly into the cavity between } \\
\text { the studs }\end{array}$ & $\begin{array}{l}\text { - No thermal bridging } \\
\text { - Simplicity and familiarity of } \\
\text { conventional stud framing } \\
\text {-Plaster is continuous }\end{array}$ & $\begin{array}{l}\text { - Bales require notching } \\
\text { - Presence of non-biodegradable } \\
\text { components such as air fins, } \\
\text { metal flashings, sealants and rigid } \\
\text { insulation } \\
\text { - Clay plaster adds weight to the } \\
\text { construction } \\
\text { - Clay plaster makes deconstruction } \\
\text { for reuse or decomposition at the } \\
\text { end of life difficult }\end{array}$ \\
\hline
\end{tabular}
Racusin, 2012, Copyright 2012 by Jaco Deva Racusin.

\section{Figure 38}

Bale infill with timber exterior

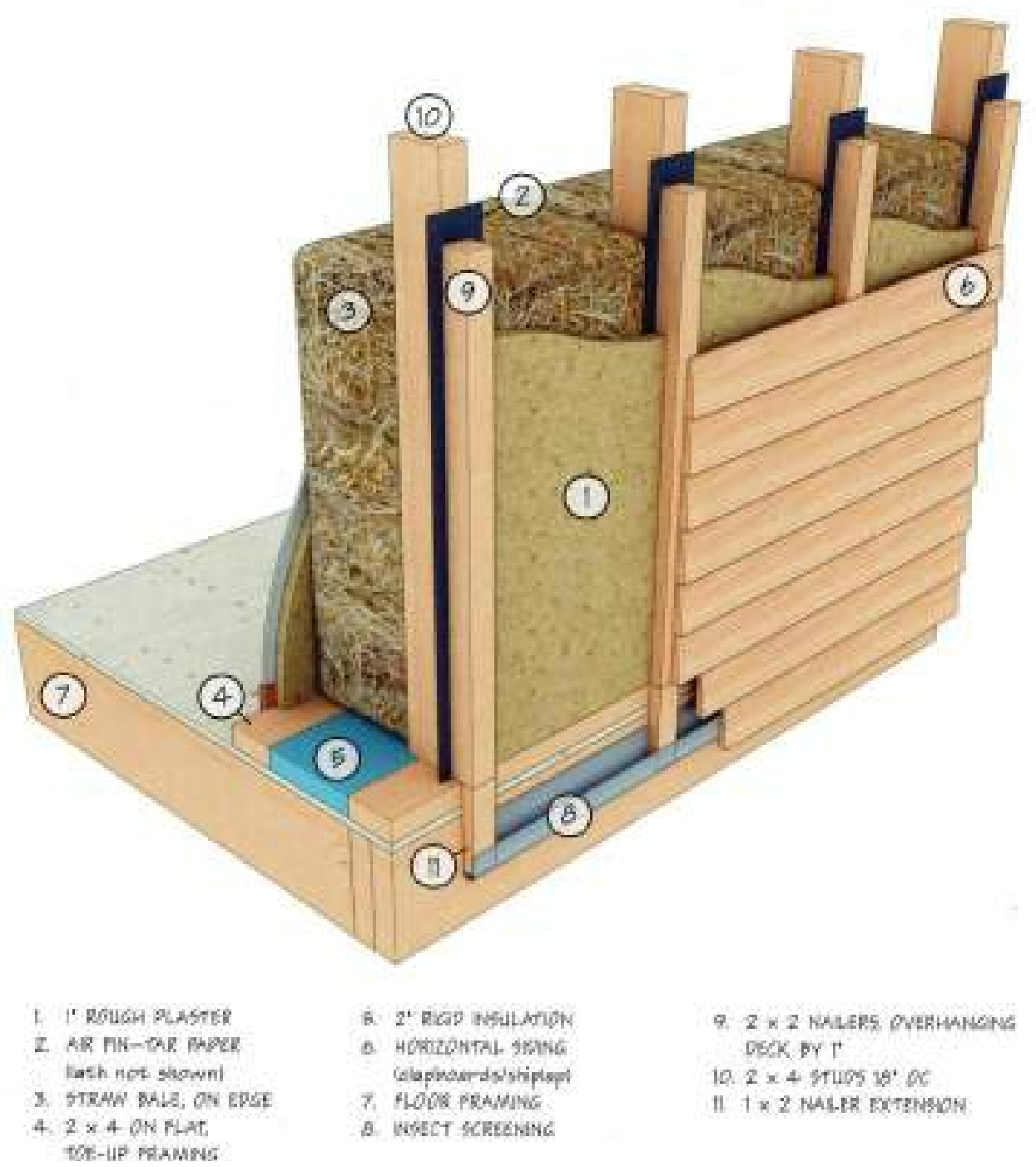

Reprinted from "The natural building companion : a comprehensive guide to integrative design and construction" by Racusin, 2012, Copyright 2012 by Jaco Deva Racusin.

\begin{tabular}{|l|l|l|}
\hline Description & Strengths & Weaknesses \\
\hline $\begin{array}{l}\text { Structural studs can be any size } \\
\text { or spacing as bales are pressed } \\
\text { against their interior face. Plaster } \\
\text { is applied on the interior face and } \\
\text { exterior face between the studs. } \\
\text { Timber cladding is present on the } \\
\text { exterior over a vented cavity. }\end{array}$ & $\begin{array}{l}\text { - No thermal bridging } \\
\text { provides cladding over vented cavity }\end{array}$ & $\begin{array}{l}\text { - Bales require notching } \\
\text { - Plastering between the battens on } \\
\text { the exterior is time consuming } \\
\text { - Presence of non-biodegradable } \\
\text { components such as air fins, } \\
\text { metal flashings, sealants and rigid } \\
\text { insulation } \\
\text { - Clay plaster adds weight to the } \\
\text { construction } \\
\text { - Clay plaster makes deconstruction } \\
\text { for reuse or decomposition at the end } \\
\text { of life difficult }\end{array}$ \\
\hline & & \\
\hline
\end{tabular}


Figure 39

Bale wrap with plastered exterior

STRAW BALE WRAP WITH EXPOSEO INTERIOR TIMBER FRAME

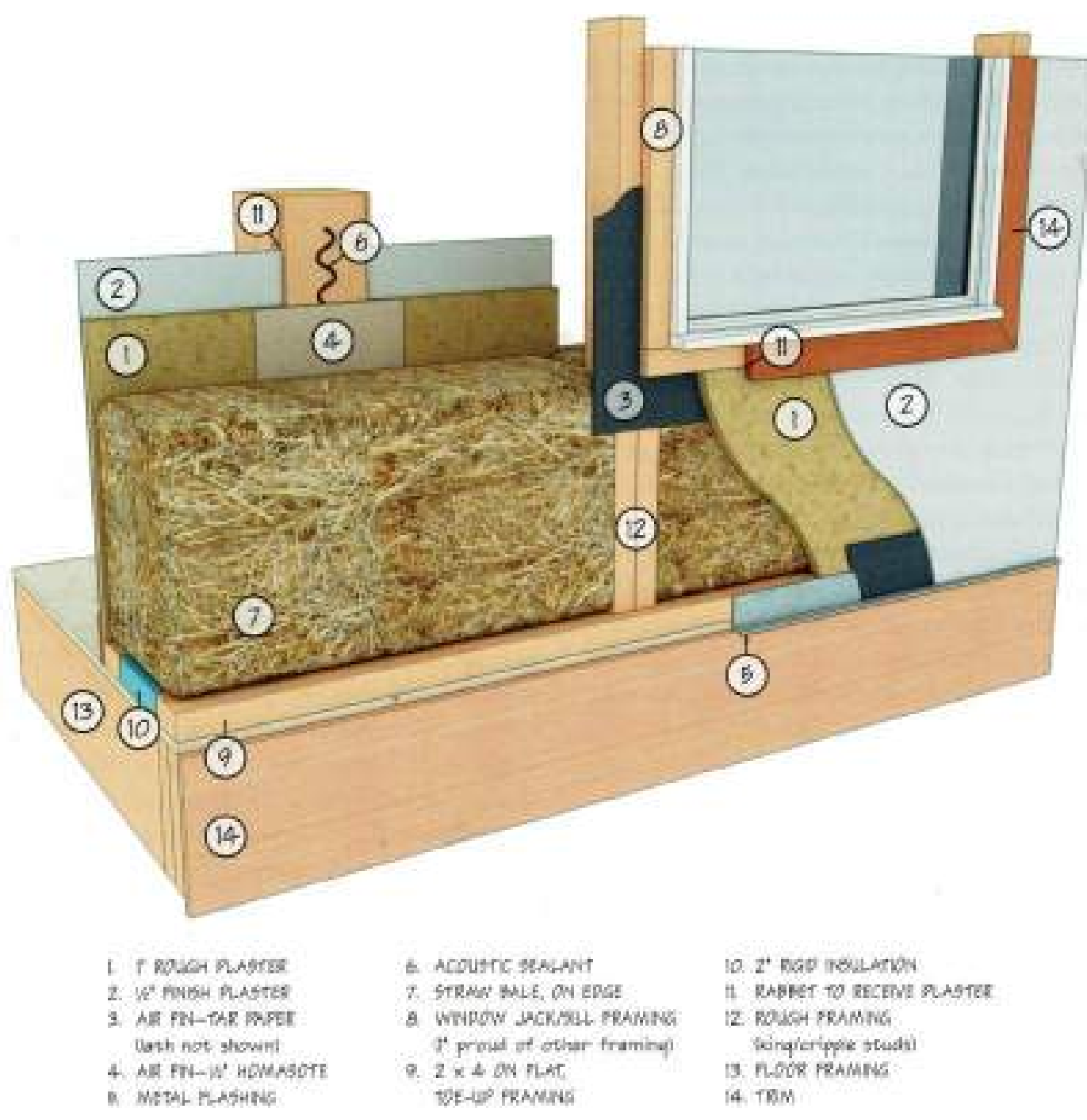

Reprinted from "The natural building companion : a comprehensive guide to integrative design and construction" by $\mathrm{J}$ Racusin, 2012, Copyright 2012 by Jaco Deva Racusin.

\begin{tabular}{|l|l|l|}
\hline Description & Strengths & Weaknesses \\
\hline $\begin{array}{l}\text { The bales and plaster wrap around } \\
\text { the exterior of the structural timber } \\
\text { frame, leaving the timber frame } \\
\text { exposed on the interior. }\end{array}$ & $\begin{array}{l}\text { - No thermal bridging } \\
\text { interiosed aesthetic }\end{array}$ & $\begin{array}{l}\text { - Presence of non-biodegradable } \\
\text { components such as air fins, metal } \\
\text { flashings, sealants and rigid insulation }\end{array}$ \\
& $\begin{array}{l}\text { - Flexibility to increase structure with } \\
\text { - Clay plaster adds weight to the } \\
\text { construction }\end{array}$ \\
& & $\begin{array}{l}\text { - Clay plaster makes ned no notrower spacings } \\
\text { for reuse or decomposition at the end } \\
\text { of life difficult } \\
\text { - Plastering between the studs on the } \\
\text { interior is time consuming }\end{array}$ \\
& & \\
\hline 78
\end{tabular}

\section{Figure 40}

Bale wrap with timber exterio

RAIN SCREEN SIDING OVER STRAW BALE WALL

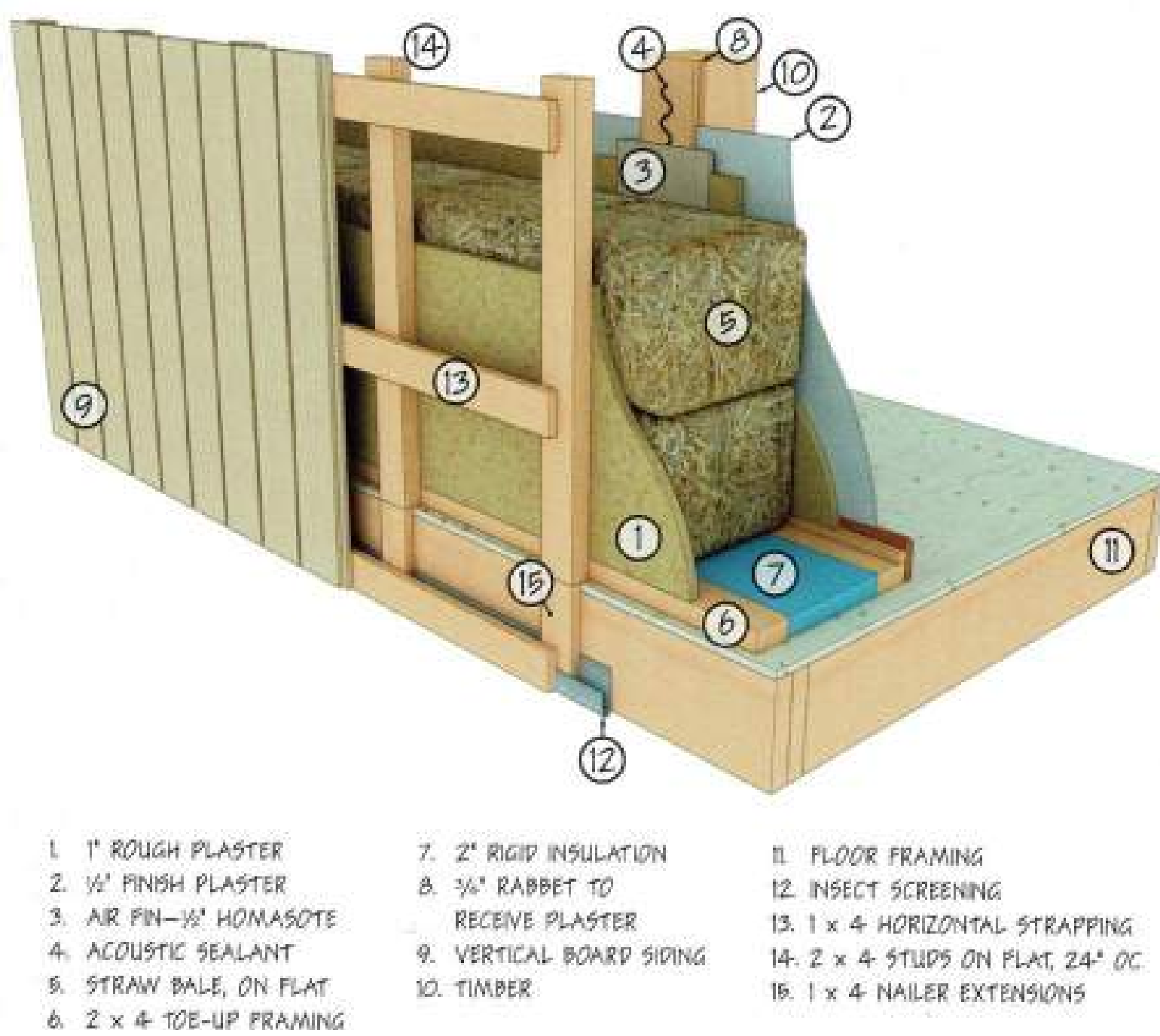

Reprinted from "The natural building companion : a comprehensive guide to integrative design and construction" by Racusin, 2012, Copyright 2012 by Jaco Deva Racusin.

\begin{tabular}{|c|c|c|}
\hline Description & Strengths & Weaknesses \\
\hline $\begin{array}{l}\text { The bales and plaster wrap } \\
\text { around the exterior of the } \\
\text { structural timber frame, leaving } \\
\text { the timber frame exposed on the } \\
\text { interior. vertical timber cladding } \\
\text { is present over a vented cavity on } \\
\text { the exterior }\end{array}$ & $\begin{array}{l}\text { - No thermal bridging } \\
\text { - Exposed structure contributes to } \\
\text { interior aesthetic } \\
\text { - Flexibility to increase structure with } \\
\text { larger studs at narrower spacings } \\
\text { - Bales need no notching } \\
\text { - Timber cladding over vented cavity } \\
\text { provides more weather protection }\end{array}$ & $\begin{array}{l}\text { - Presence of non-biodegradable } \\
\text { components such as air fins, metal } \\
\text { flashings, sealants and rigid insulation } \\
\text { - Clay plaster adds weight to the } \\
\text { construction } \\
\text { - Clay plaster makes deconstruction } \\
\text { for reuse or decomposition at the end } \\
\text { of life difficult } \\
\text { - Plastering between the studs on the } \\
\text { interior is time consuming }\end{array}$ \\
\hline
\end{tabular}


Wall Proposal 1

Scale 1:10

Exterior

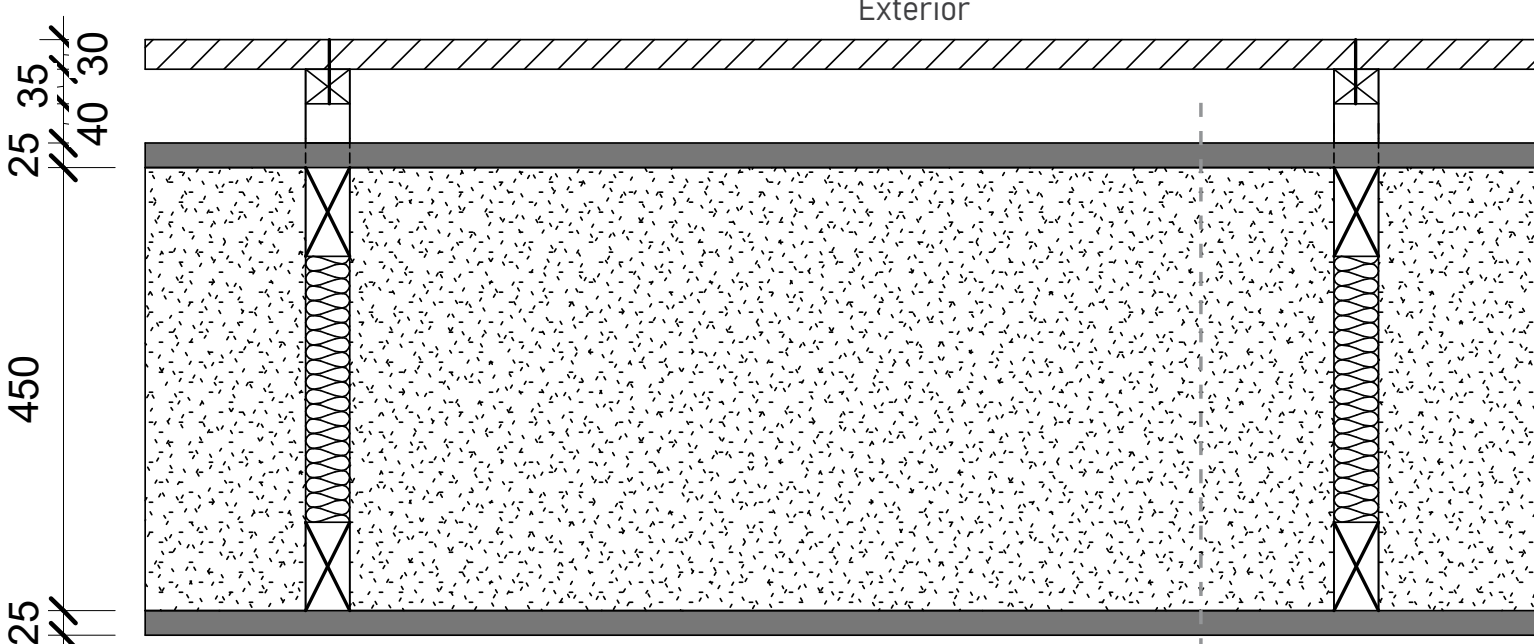

:

45

1000

Interior

45
$\times 1$

'Calculation line

\begin{tabular}{|c|c|c|}
\hline \multicolumn{2}{|l|}{ Material } & \multirow{2}{*}{\begin{tabular}{|l|} 
Function \\
Cladding
\end{tabular}} \\
\hline$Z \triangle Z Z$ & $\begin{array}{l}\text { Untreated } \\
\text { Macrocarpa } \\
\text { Cladding } \\
\end{array}$ & \\
\hline & Screws & Fixing \\
\hline$凶$ & $\begin{array}{l}\text { Untreated } \\
\text { Douglas Fir } \\
\text { Cavity Batten }\end{array}$ & $\begin{array}{l}\text { Provide vented cavity } \\
\text { depth, provide place to } \\
\text { fix cladding }\end{array}$ \\
\hline & Clay Plaster & $\begin{array}{l}\text { Protect wool insulation } \\
\text { from condensation } \\
\text { and moisture (vapour } \\
\text { control layer) } \\
\text { Provide air seal }\end{array}$ \\
\hline X & $\begin{array}{l}\text { Untreated } \\
\text { Douglas Fir } \\
\text { Framing }\end{array}$ & Structure \\
\hline 0 & Straw Bale & Insulation \\
\hline 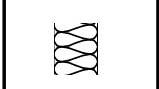 & Pure Wool & Insulation \\
\hline X & $\begin{array}{l}\text { Untreated } \\
\text { Douglas Fir } \\
\text { Framing }\end{array}$ & Structure \\
\hline & Clay Plaster & $\begin{array}{l}\text { Protect wool insulation } \\
\text { from condensation } \\
\text { and moisture (vapour } \\
\text { control layer) } \\
\text { Provide air seal }\end{array}$ \\
\hline
\end{tabular}

\begin{tabular}{|l|l|}
\hline Thermal Resistance & Vapour Resistance \\
\hline $5.37 \mathrm{~m}^{2} \mathrm{~K} / \mathrm{W}$ & $5.68 \mathrm{MNs} / \mathrm{g}$ \\
\hline
\end{tabular}

The precedent analysis highlighted and literature also supports that including timber cladding over a ventilated cavity increases weather protection and reduces the chance of the bales getting wet (BRANZ, 2015). Therefore, timber cladding over a ventilated cavity will be used for every wall proposal.

Wall proposal 1 is a bale infill design. The precedent review revealed that having to notch the bales is a primary weakness of this construction approach. In addition, the non-continuous nature of the plaster between the cavity battens required for the timber cladding was also noted as a weakness. This wall proposal therefore seeks to eliminate notehing and increase the continuity of the plaster whilst maintaning timber cladding over a ventlated cavity. The wall proposal places the structure . used pure wool insulation to insulate the cavity.
Wall Proposal 2

Scale 1:10

Exterior

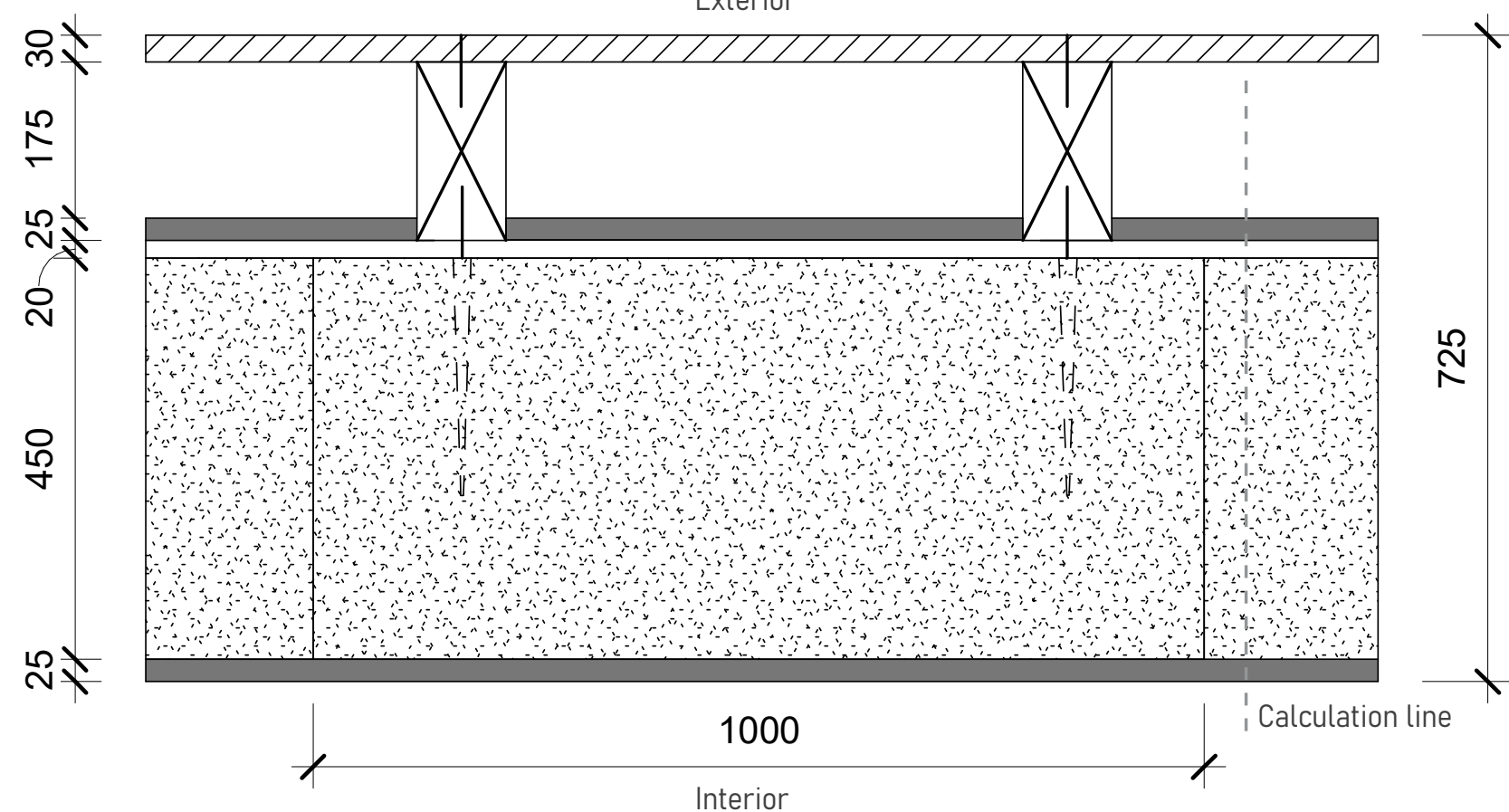

\begin{tabular}{|c|l|l|}
\hline \multicolumn{2}{|l|}{ Material } & Function \\
\hline 1 & $\begin{array}{l}\text { Untreated } \\
\text { Macrocarpa } \\
\text { Cladding }\end{array}$ & Cladding \\
\hline Screws & Fixing \\
\hline Framing & $\begin{array}{l}\text { Untreated } \\
\text { Douglas Fir } \\
\text { Frang }\end{array}$ & $\begin{array}{l}\text { Structure, provide } \\
\text { vented cavity depth, } \\
\text { provide place to fix } \\
\text { cladding }\end{array}$ \\
\hline & $\begin{array}{l}\text { Clay Plaster } \\
\text { Protect straw bale } \\
\text { insulation from } \\
\text { condensation and } \\
\text { moisture (vapour } \\
\text { control layer) } \\
\text { Provide air seal }\end{array}$ \\
\hline & $\begin{array}{l}\text { Untreated } \\
\text { Douglas Fir } \\
\text { Boards }\end{array}$ & $\begin{array}{l}\text { Provide substrate for } \\
\text { clay plaster to be laid }\end{array}$ \\
\hline $\begin{array}{l}\text { Untreated } \\
\text { Douglas-fir } \\
\text { Piercing Rods }\end{array}$ & $\begin{array}{l}\text { Tie straw bales into } \\
\text { structure }\end{array}$ \\
\hline $\begin{array}{l}\text { Insul Bate } \\
\text { Insulion }\end{array}$ & $\begin{array}{l}\text { Clay Plaster } \\
\text { Thermal insulation layer }\end{array}$ & $\begin{array}{l}\text { Protect straw bale } \\
\text { insulation from } \\
\text { condensation and } \\
\text { moisture (vapour } \\
\text { control layer) } \\
\text { Provide air seal }\end{array}$ \\
\hline & \\
\hline
\end{tabular}

\begin{tabular}{|l|l|}
\hline Thermal Resistance & Vapour Resistance \\
\hline
\end{tabular} $5.552 \mathrm{~m}^{2} \mathrm{~K} / \mathrm{W}$ $16.51 \mathrm{MNs} / \mathrm{g}$

Wall proposal 2 is a bale wrap design. The design seeks construction with timber cladding by using one timber member to provide structure and act as a cavity batten The straw bales are pierced into place to fix them to the building's structure. to increase the resource efficiency of a typical bale wrap 
Wall Proposal 3

Scale 1:10

Exterior

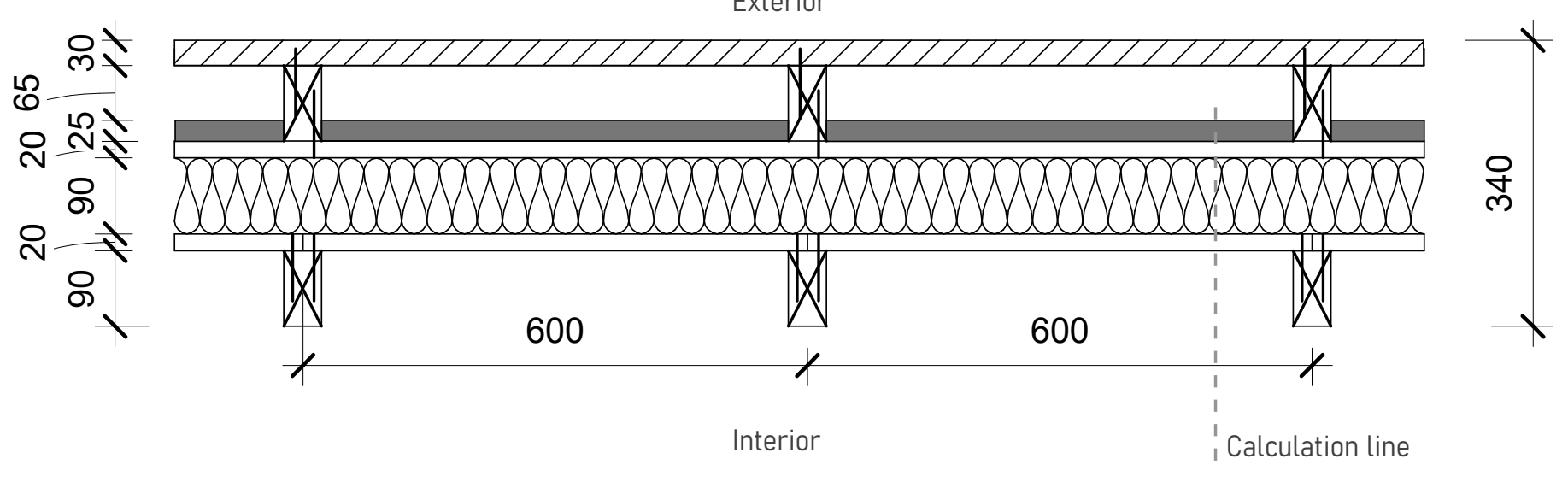

\begin{tabular}{|c|c|c|}
\hline \multicolumn{2}{|l|}{ Material } & \multirow{2}{*}{$\begin{array}{l}\text { Function } \\
\text { Cladding }\end{array}$} \\
\hline 777 & \begin{tabular}{|l} 
Untreated \\
Macrocarpa \\
Cladding \\
\end{tabular} & \\
\hline & Screws & Fixing \\
\hline 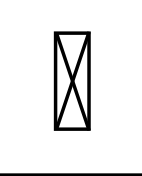 & $\begin{array}{l}\text { Untreated } \\
\text { Douglas Fir } \\
\text { Framing }\end{array}$ & $\begin{array}{l}\text { Structure, provide } \\
\text { vented cavity depth, } \\
\text { provide place to fix } \\
\text { cladding }\end{array}$ \\
\hline & Clay Plaster & $\begin{array}{l}\text { Protect wool insulation } \\
\text { from condensation and } \\
\text { moisture (vapour control } \\
\text { layer) }\end{array}$ \\
\hline & $\begin{array}{l}\text { Untreated } \\
\text { Douglas Fir } \\
\text { Boards }\end{array}$ & $\begin{array}{l}\text { Provide substrate for } \\
\text { clay plaster to be laid }\end{array}$ \\
\hline & \begin{tabular}{|l|}
$\begin{array}{l}\text { Pure Wool } \\
\text { Insulation }\end{array}$ \\
\end{tabular} & Thermal insulation layer \\
\hline & $\begin{array}{l}\text { Untreated } \\
\text { Douglas Fir } \\
\text { Boards }\end{array}$ & Interior finsh \\
\hline 1 & Screws & Fixing \\
\hline X & $\begin{array}{l}\text { Untreated } \\
\text { Douglas Fir } \\
\text { Framing }\end{array}$ & $\begin{array}{l}\text { Structure, provide place } \\
\text { to fix interior boards }\end{array}$ \\
\hline
\end{tabular}

Wall Proposal 4

Scale 1:10

Exterior

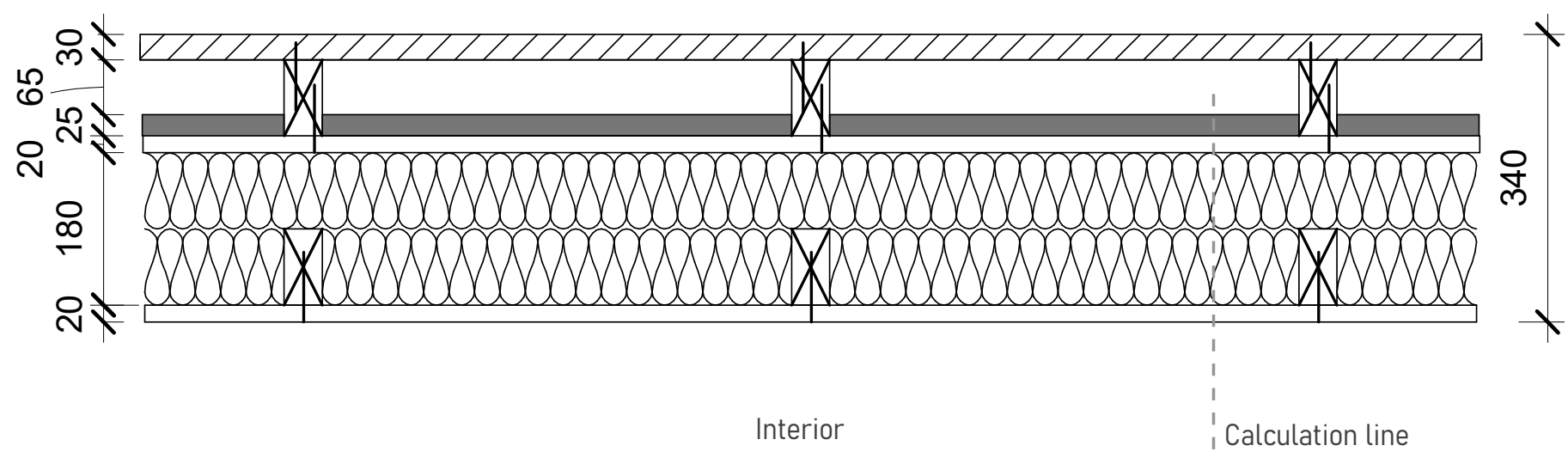

\begin{tabular}{|c|c|c|}
\hline \multicolumn{2}{|l|}{ Material } & \multirow{2}{*}{\begin{tabular}{|l} 
Function \\
Cladding
\end{tabular}} \\
\hline TIZZ & \begin{tabular}{|l|} 
Untreated \\
Macrocarpa \\
Cladding \\
\end{tabular} & \\
\hline & Screws & Fixing \\
\hline D & $\begin{array}{l}\text { Untreated } \\
\text { Douglas Fir } \\
\text { Framing }\end{array}$ & $\begin{array}{l}\text { Structure, provide } \\
\text { vented cavity deptth, } \\
\text { provide place to fix } \\
\text { cladding }\end{array}$ \\
\hline & Clay Plaster & $\begin{array}{l}\text { Protect wool insulation } \\
\text { from condensation and } \\
\text { moisture (vapour control } \\
\text { layer) }\end{array}$ \\
\hline & $\begin{array}{l}\text { Untreated } \\
\text { Douglas Fir } \\
\text { Boards }\end{array}$ & $\begin{array}{l}\text { Provide substrate for } \\
\text { clay plaster to be laid }\end{array}$ \\
\hline 1000 & \begin{tabular}{|l|} 
Natural Wool \\
Insulation \\
\end{tabular} & Thermal insulation layer \\
\hline D & $\begin{array}{l}\text { Untreated } \\
\text { Douglas Fir } \\
\text { Framing }\end{array}$ & Interior finsh \\
\hline & Screws & Fixing \\
\hline & $\begin{array}{l}\text { Untreated } \\
\text { Douglas Fir } \\
\text { Boards }\end{array}$ & $\begin{array}{l}\text { Structure, provide place } \\
\text { to fix interior boards }\end{array}$ \\
\hline
\end{tabular}

\begin{tabular}{|l|l|}
\hline Thermal Resistance & Vapour Resistance \\
\hline $5.83 \mathrm{~m}^{2} \mathrm{~K} / \mathrm{W}$ & $24.10 \mathrm{MNs} / \mathrm{g}$ \\
\hline
\end{tabular}

Wall proposal 4 is identical to wall proposal 3 except the structure is not exposed on the interior but instead used as an additional insulation cavity. 


\subsection{Standardised Block Module}

Due to the fact that combining both the bio-sphere and the tech-sphere is the optimum waste reduction strategy a biodegradable and reuse construction module should be pursued. This research proposes a standardised prefabricated biodegradable construction brick, reminiscent of Lego. Such a brick can be simply deconstructed at the end of life and reused in an identical application in a future project. Research suggests that demountable standardised prefabricated modules could, indeed allow for a circular economy within the construction industry (Minunno et al., 2018).

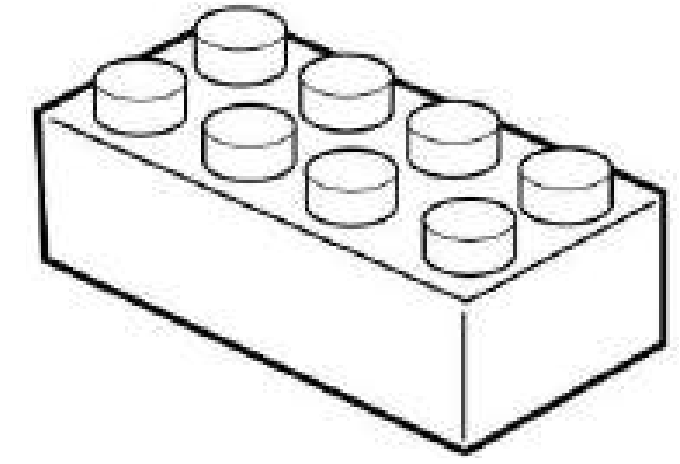

A biodegradable and reusable construction module
Figure 42

Just BioFibre Hempcrete Building Block

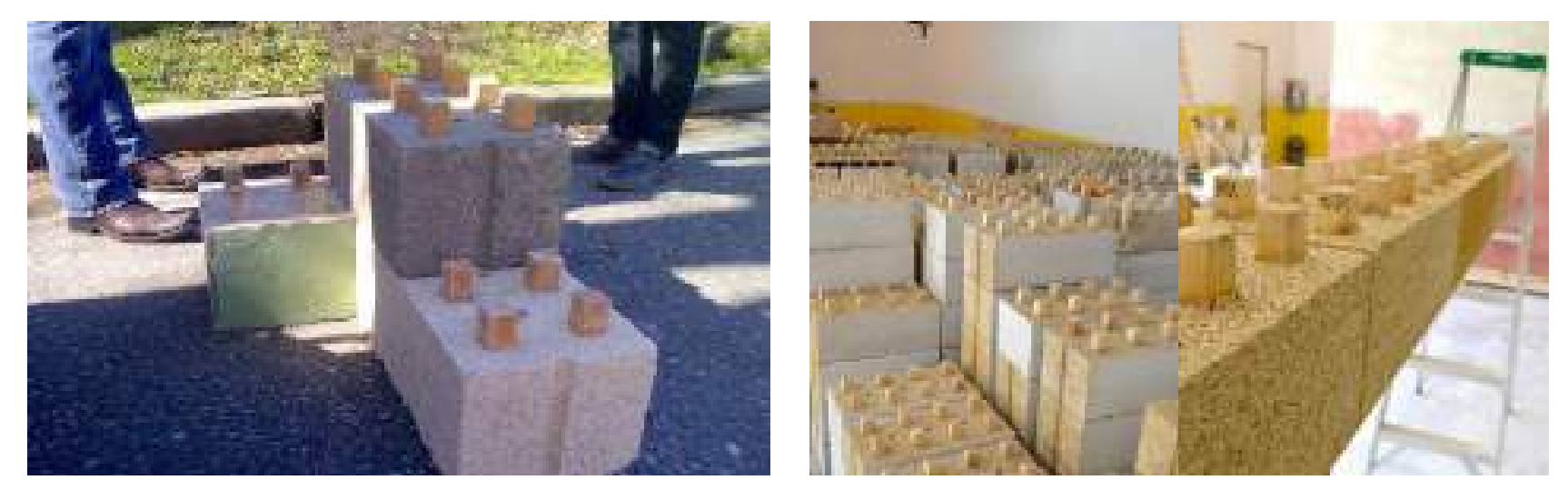

Retrieved from Hempcrete Walls (http://hempcretewalls.com/2015/04/22/more-hempcrete-structural-building-blockinfo-vancouver-bc/) on 2 June 2020

\begin{tabular}{|l|l|l|}
\hline Description & Strengths & Weaknesses \\
\hline - Made from Hempcrete (hemp, lime & - Load-bearing up to 2 storeys & - Requires stainless steel fixings \\
and sand) with timber structural & - Fire resistant & - Not weatherproof \\
members & - Very light & \\
$-300 \times 300 \times 600 \mathrm{~mm}$ & - Highly insulative & \\
-8 locations of structural connection & - No thermal bridging & \\
(2x4 brick) & & \\
\hline
\end{tabular}

\section{Figure 43}

Oryzatech Stak Blocks
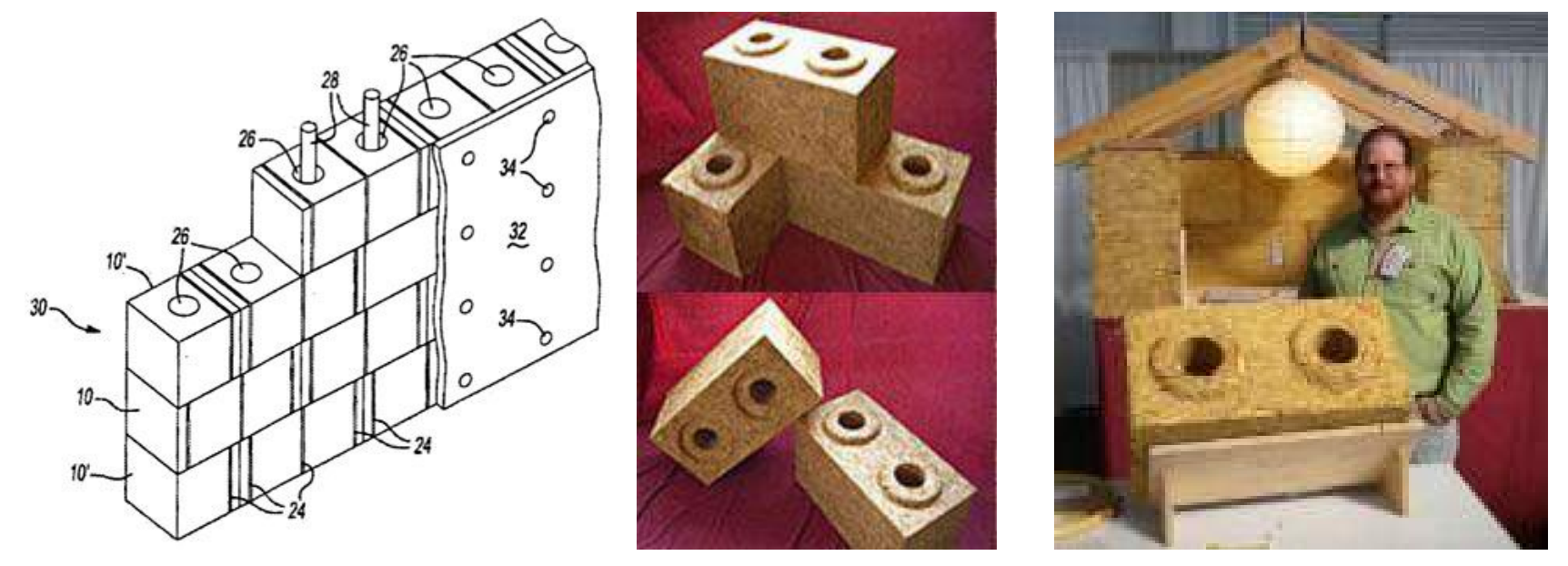

Retrieved from Treehugger (https://www.treehugger.com/sustainable-product-design/oryzatech-strawbale-legoblocks-for-grown-ups.html) on 2 June 2020

\begin{tabular}{|c|c|c|}
\hline Description & Strengths & Weaknesses \\
\hline $\begin{array}{l}\text { - Made from compressed rice straw } \\
-300 \times 300 \times 600 \mathrm{~mm} \\
-2 \text { locations of structural connection } \\
\text { (1×2 brick) }\end{array}$ & $\begin{array}{l}\text { - Load-bearing } \\
\text { - Fire resistant } \\
\text { - Reasonably light at } 13.5 \mathrm{Kg} \\
\text { - Highly insulative at R-8.8 } \\
\text { - No thermal bridging }\end{array}$ & $\begin{array}{l}\text { - Relieves heavily on the use of } \\
\text { steel rebar rods } \\
\text { - Undisclosed binder which may } \\
\text { compromise biodegradability } \\
\text { - Not weatherproof }\end{array}$ \\
\hline
\end{tabular}

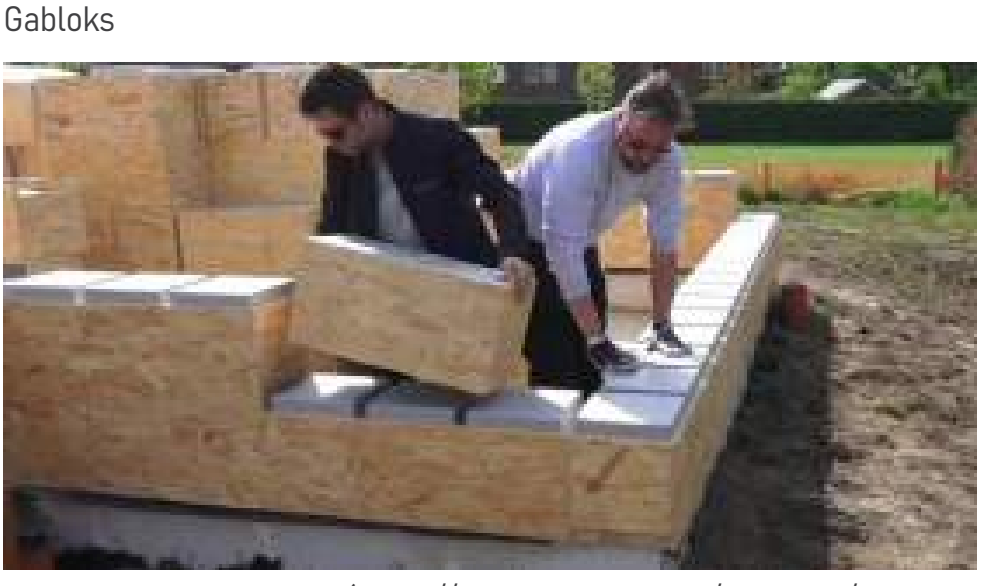

Retrieved from Linkedin (https://www.linkedin.com/company/

gablok/?trk=similar-companies_org_title\&originalSubdomain=ua) on 31 June 2020

\begin{tabular}{|c|c|c|}
\hline Description & Strengths & Weaknesses \\
\hline $\begin{array}{l}-18 \mathrm{~mm} \text { wood chip panel casing with } \\
\text { rigid EPS blocks inside } \\
-300 \times 300 \times 600 \mathrm{~mm} \\
-2 \text { locations of structural connection } \\
\text { ( } 2 \times 4 \text { brick) }\end{array}$ & $\begin{array}{l}\text { - Load-bearing up to } 3 \text { storeys } \\
\text { - Fire resistant } \\
\text { - Very light } \\
\text { - Highly insulative } \\
\text { - Weatherproof }\end{array}$ & $\begin{array}{l}\text { - Wood chip panel uses glue which } \\
\text { compromises biodegradability } \\
\text { - Rigid EPS insulation is non- } \\
\text { biodegradable and is essential for } \\
\text { the structural intergrity of the design } \\
\text { - Thermal bridging through timber } \\
\text { casing }\end{array}$ \\
\hline
\end{tabular}




\begin{tabular}{|l|l|}
\hline General Issues & Learnings \\
\hline $\begin{array}{l}\text { - Existing biodegradable modules are either not structural } \\
\text { or weather proof. }\end{array}$ & $\begin{array}{l}-1 \times 2 \text { or } 2 \times 4 \text { or } 4 \times 8 \text { ect modules allow modules to be used } \\
\text { on corners }\end{array}$ \\
\hline
\end{tabular}

Module Concept Sketches
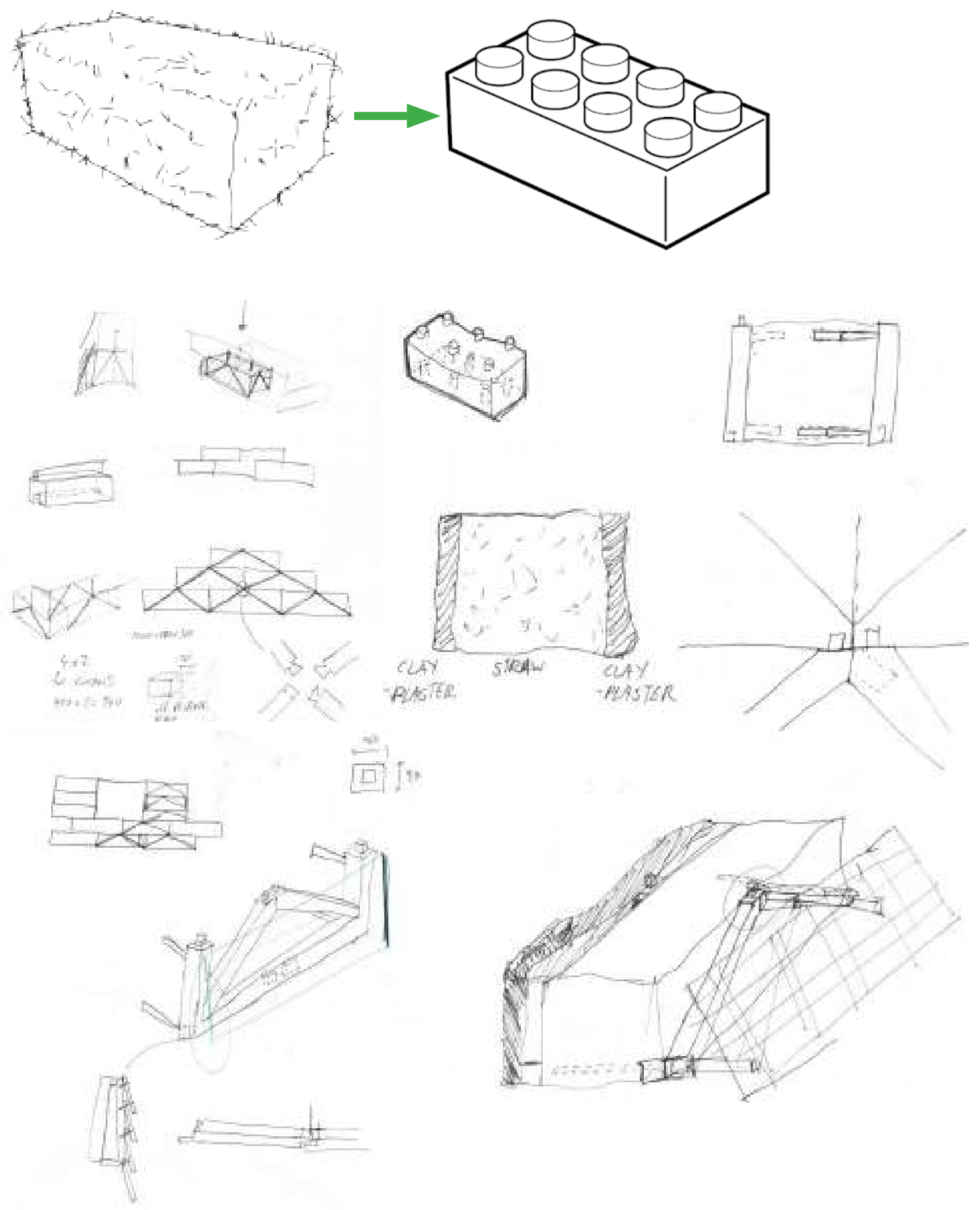

[다.

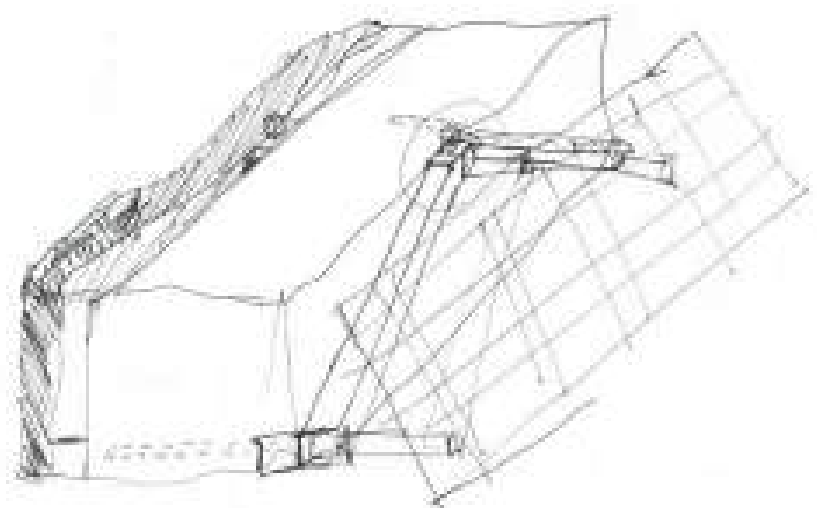

Standardised Block Concept

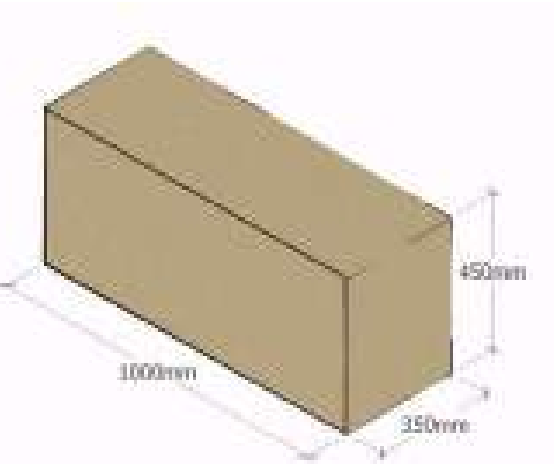

1. NZ standard straw bale

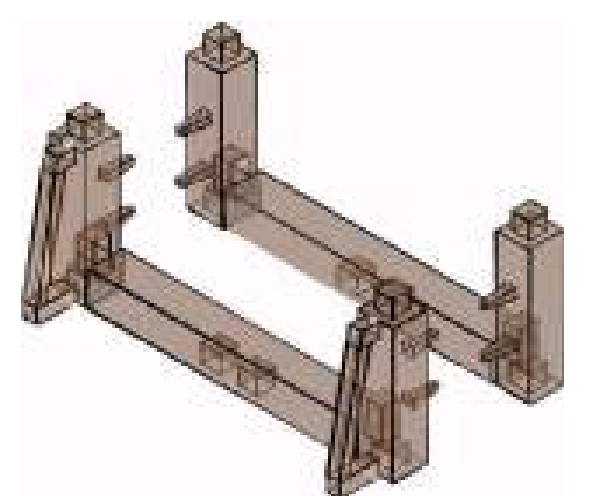

3. Slot in horizontal Douglas-fir member

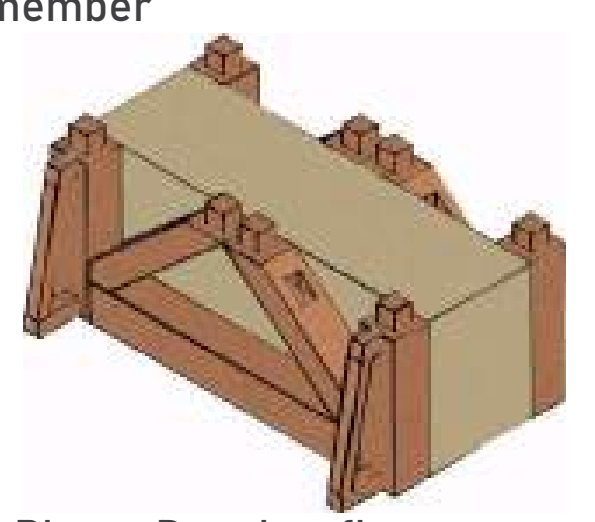

5. Pierce Douglas-fir exo-structure into straw bale

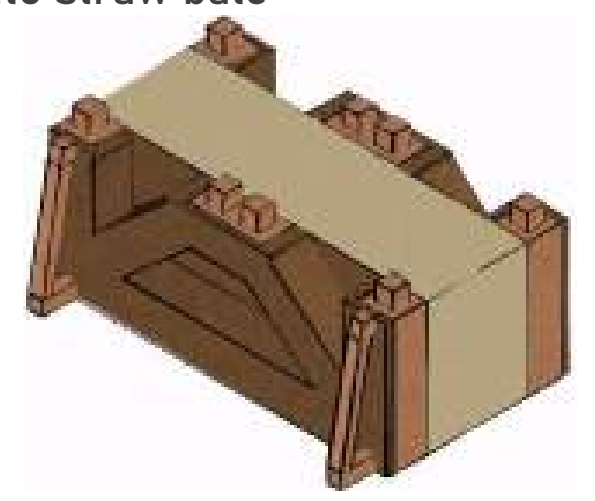

7. Coat exterior and interior faces with $30 \mathrm{~mm}$ of clay plaster

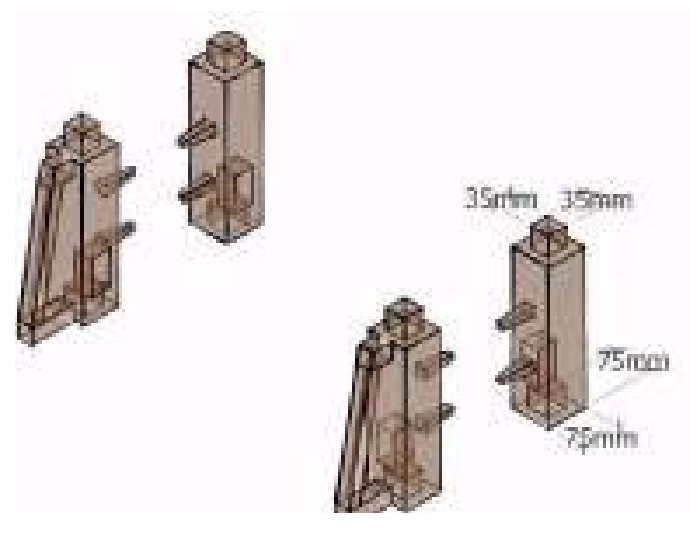

2. Vertical timber struts

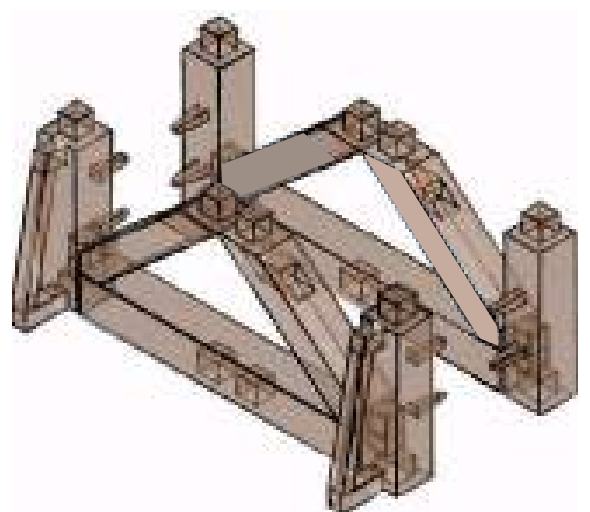

4. Slot in Douglas-fir cross braces

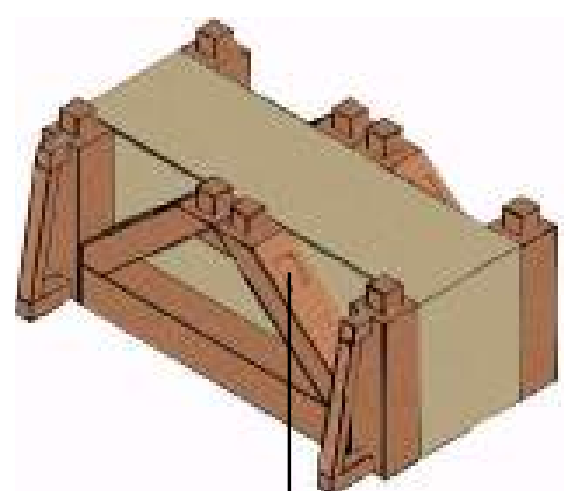

6. Slot in Douglas-fir brace peg member

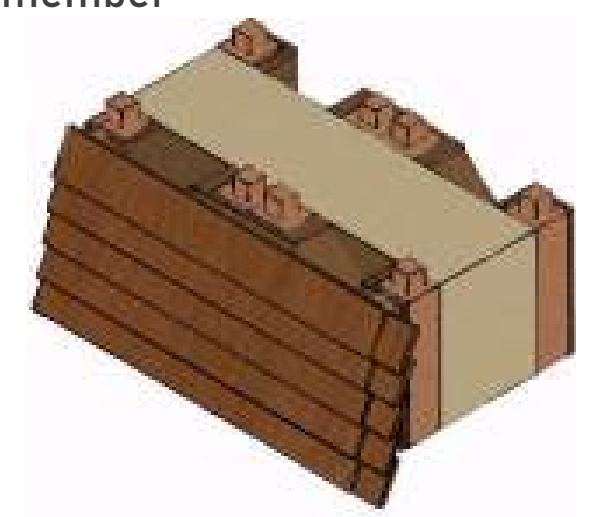

8. Screw in Macrocarpa weatherboards 


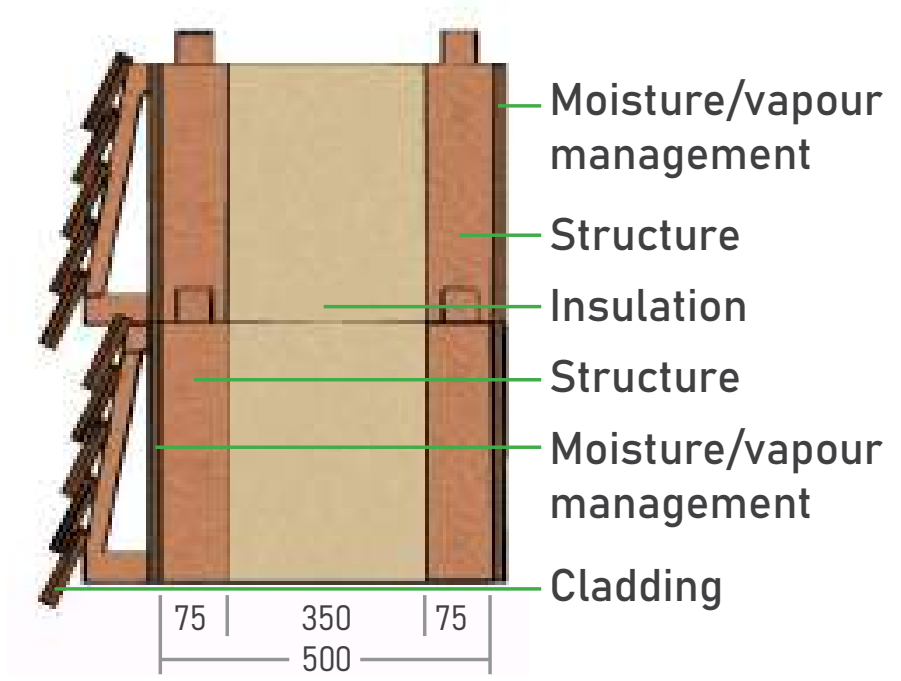

Structure Load Paths

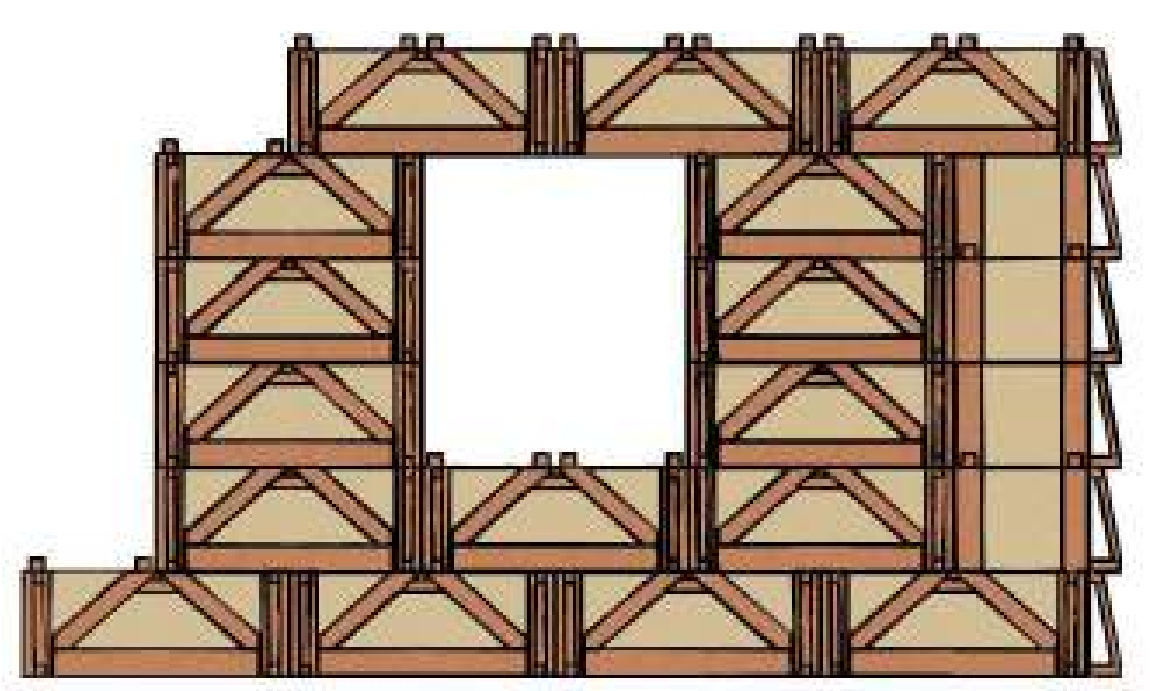

\begin{tabular}{|l|l|l|}
\hline Weight & Thermal Resistance & Vapour Resistance \\
\hline $77.4 \mathrm{Kg}$ & $5.44 \mathrm{~m}^{2} \mathrm{~K} / \mathrm{W}$ & $85.9 \mathrm{MNs} / \mathrm{g}$ \\
\hline
\end{tabular}
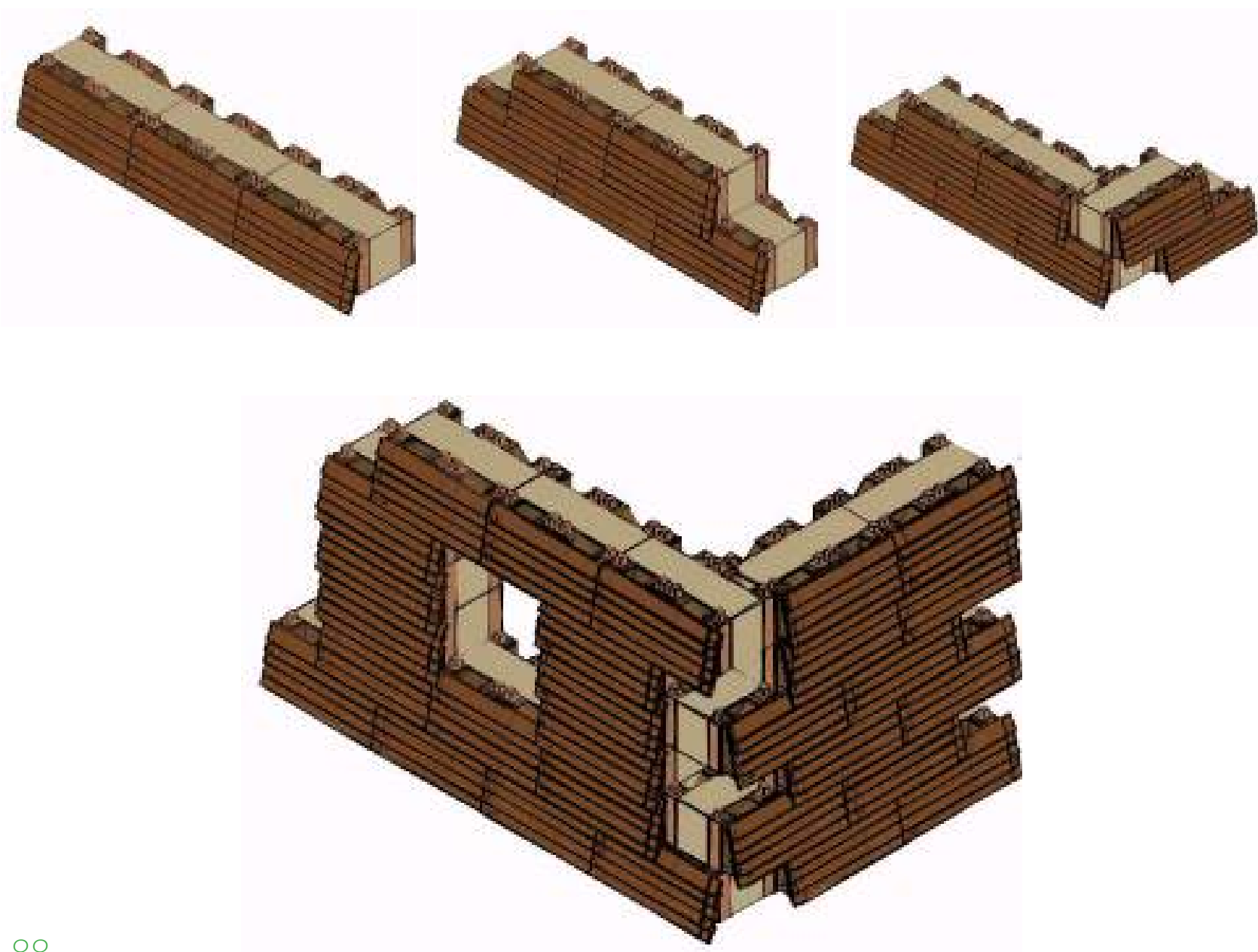

Half Brick for Corners and Openings
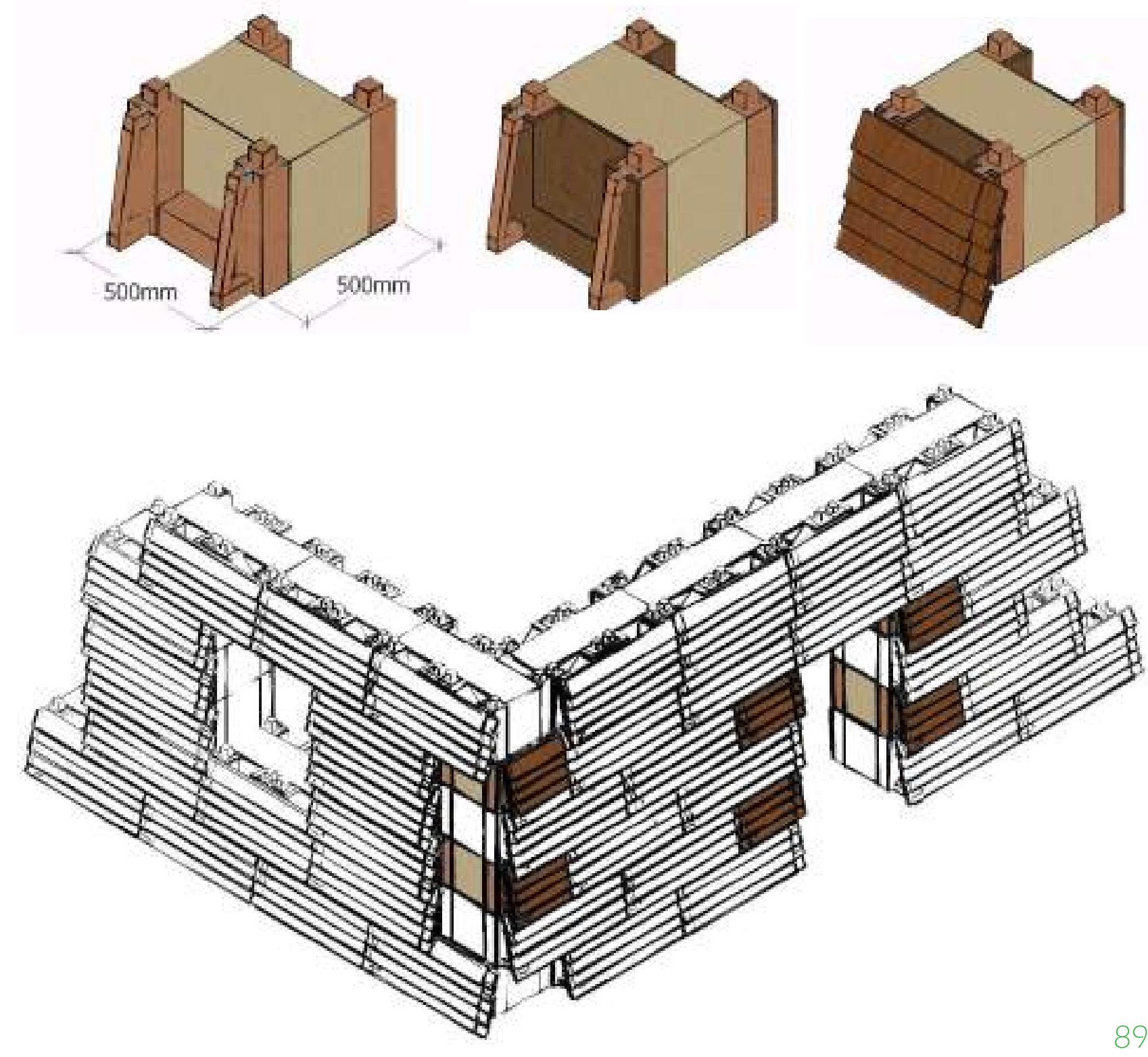


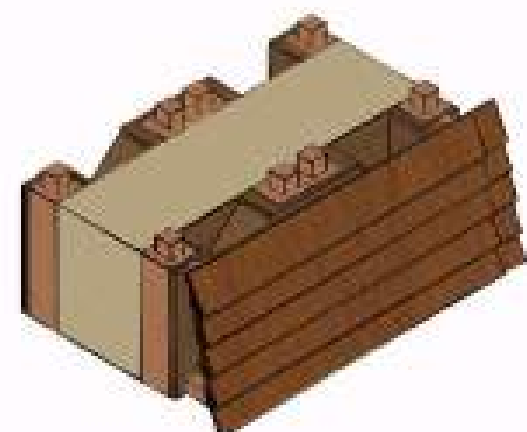

1. Standard Module

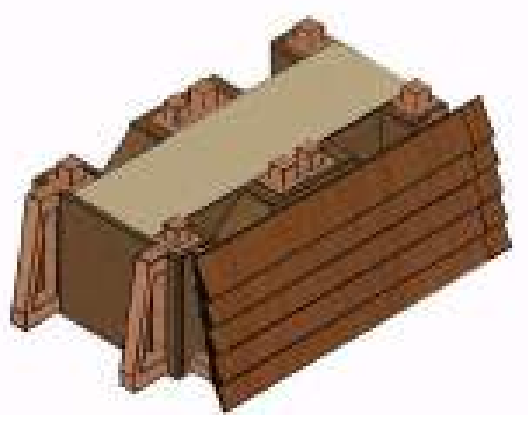

3. Coat in $30 \mathrm{~mm}$ clay plaster

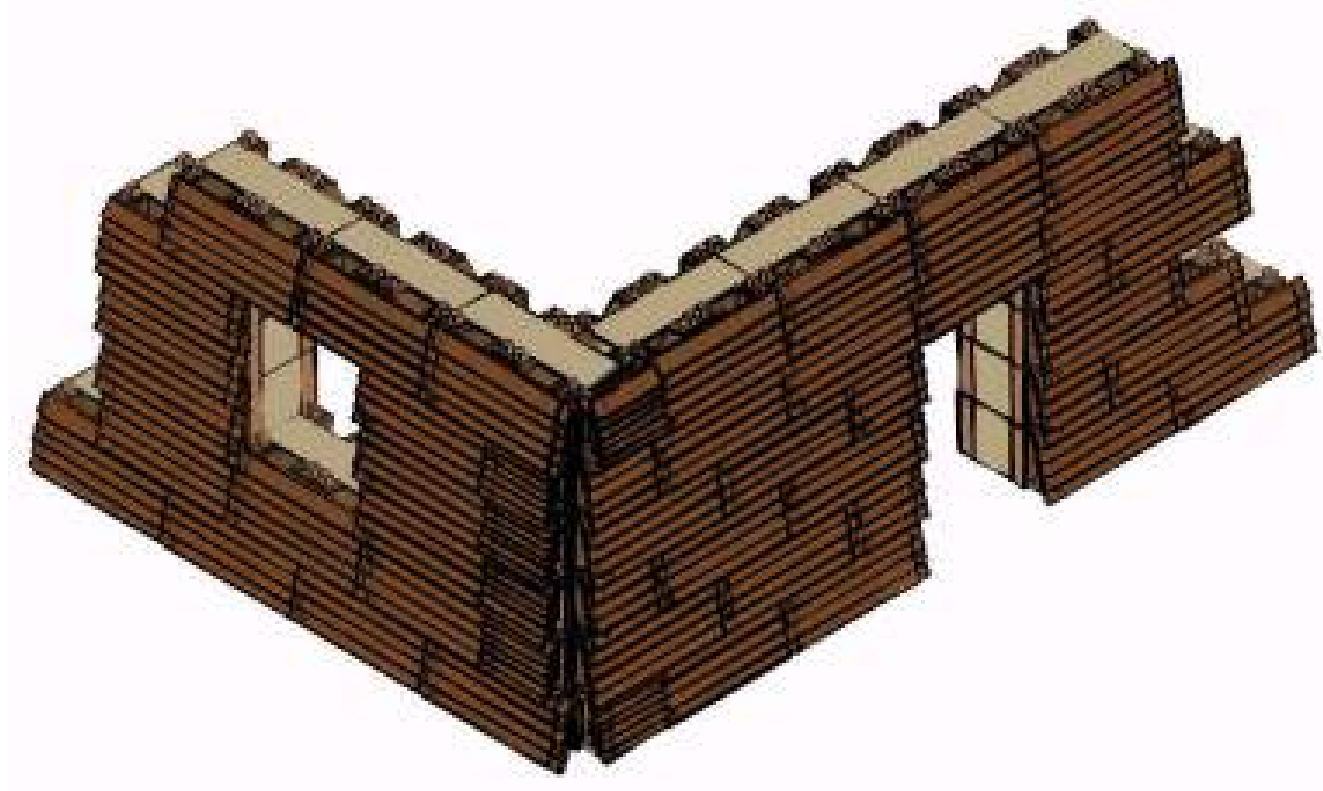

The construction brick is derived from dimensions of the standard New Zealand straw bale which is $350 \mathrm{~mm} \times 450 \mathrm{~mm} \times 1000 \mathrm{~mm}$ (Hall, 2019 ). Identical timber framing is pierced into both sides of the straw bale so that the overall dimensions of the brick are $1000 \mathrm{~mm} \times 500 \mathrm{~mm}$ (2x4). This means that the block can be used on corners. points to adjacent blocks. Clay plaster is present on both

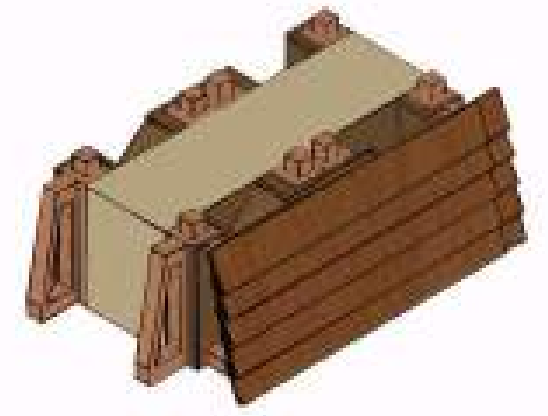

2. Screw in cavity battens

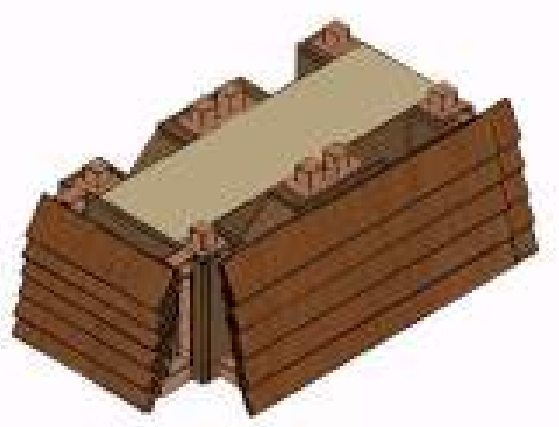

4. Screw in macrocarpa weatherboards

sides to protect the straw bales and timber weatherboards are fixed over a vented cavity. This structural insulated weathertight block can then be simply constructed and deconstructed and easily reused on similar future projects. Their small scale and standardised nature of the blocks means that the same block can be used to create a
vast variety of building scales and layouts.

\subsection{Prefabricated Wall Panels}

Why do we need a prefabricated panel?

A prefabrication wall panel has the potential to lower the risk associated with using bio-based insulation materials and increase their uptake. The controlled and dry ins the chunce of the bio-based insurtion mactial being compromised through mosture. For straw bate being compromised through moisture. For straw bale of the possibity of plastering all year round improved of the possibily of plastering all year round, improved

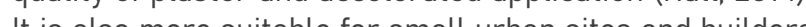
is also more sutable for sm th ban siles and bulders 2014)

The consistency and improved quality assurance of the product due to the interior factory setting will allow the straw or pure wool insulated panel to receive BRANZ CodeMark or Appraisal. This will allow the panel to gain acceptance in the mainstream market. In addition, prefabrication in general offers reduced site labour which can reduce costs.

No biodegradable prefabricated panel in NZ

No straw or pure wool insulated prefabricated wall panels exist in NZ. Straw-insulated prefabricated panels are produced in the UK and Lithuania by the companies ModCell and Ecococon respectively but no prefabricated panels using pure wool insulation are produced anywhere. In New Zealand experimental prototypes of straw bale insulated prefabricated wall panels have been developed and prefabricated wall panels that use wool blend insulation are produced in New Zealand by Ecopanel. Straw bale prototype prefabricated walls have been developed in New Zealand by Sol design in 2011 and 2014 (Hall, 2014). In 201 , Sol Design constructed a $10 \mathrm{~m} 2$ experimental prefabilicated structure in Geraldne, Canterbury (Hall, 2014). They then began working on prefabricated straw preperty in Geraldinucted a power sher (figure 44 ) (Hall, 2014). Mre recently, in 2019 . Min Hall a senior) (Hall, t Unitec, has produced for prototype strow bactur at Untec, has produced four pro hitype straw bale wall panels at onethird scale, using dif optons includng laner wertical trusses, and a ' $C$ ' fram where san timber and plywood are incorporate to form a channel section (Hall, 2019).
Figure 44

Experimental prefabricated straw shed Geraldine Canterbury, New Zealand, 2011
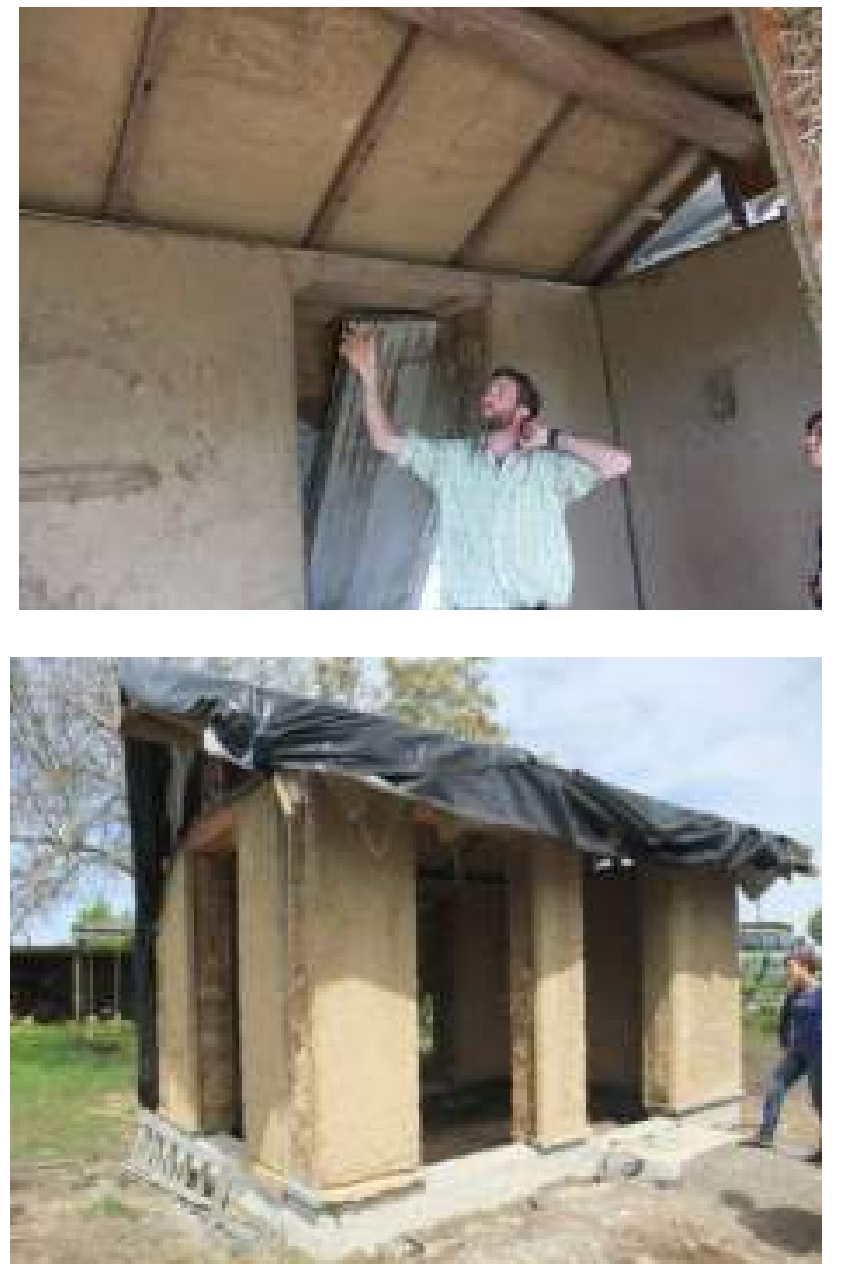

Reprinted from "Is there a place for natural building in $\mathrm{New}$ Zealand's conventional housing market? - a prefabricated straw bale case study" by M. Hall, 2014, Copyright 2014 by Min Hall. 


\section{Methodology}

Prefabricated straw wall panel literature and precedents are reviewed to inform how wool insulation could be best be used within a straw a prefabricated wall panel. This literature also supplied suitable construction approaches for pure wool insulation as it is a material with similar moisture management requirements to straw. This informed three prefabricated wall panel designs. The Ecococon panel was used as a base for prefabricated explorations using wool in combination with straw insulation. This is because of their benefits over the ModCell@ Panel. Compressed straw is used in the Ecococon panels instead of bales which allows the panels dimensional flexibility. This makes the panels adaptable to almost any design which keeps site labour cost low (Ecococon, 2020). Ecococon also produces a range of panels for dirferent applications (igure 45). The design proposals are based on the standard (non-braced) wall panels from Ecococon with the intent that the lessons learned can be applied to the full range of panels. The panel designs are all of the consistent dimensions of $0.35 \mathrm{~m} \times 1.8 \mathrm{~m} \times 2.4 \mathrm{~m}$ to allow direct comparison.

Figure $\mathbf{4 5}$

Ecococon panel types

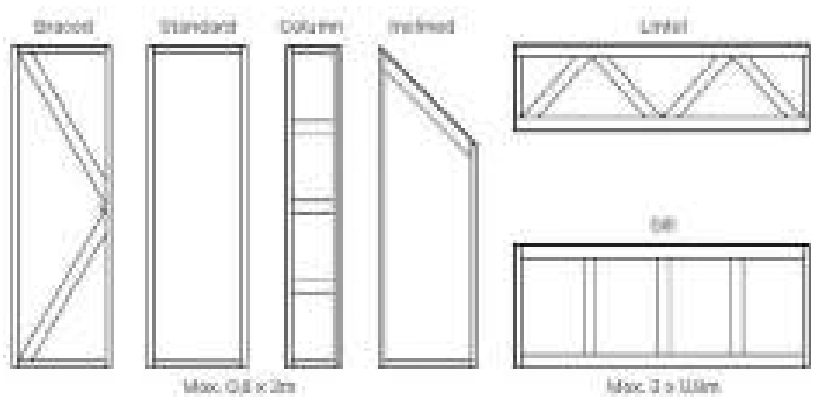

Reprinted from "Planning Guide" by Ecococon, 2020 Copyright 2020 by Ecococon.

\section{Prefabricated Straw Panel Literature}

\section{Review}

There are two processes for prefabricated straw bale panel construction- the wet process (figure 46) and the dry process (figure 47) (Magwood, 2016). The wet process uses plaster and the dry process uses a permeable magnesium oxide or gypsum sheathing on the interior and exterior faces (Magwood, 2016). The wet and dry process can be mixed with one face covered in plaster and the other in a permeable sheathing or combined with each face using both a plaster and permeable sheathing (Magwood 2016) Clay or lime plaster is biodegradable, but magnesium oxide or gypsum sheathings are not. This means the wet method is the only biodegradable construction option for a prefabricated straw bale panel.

\section{Figure 46}

\section{Wet Process}

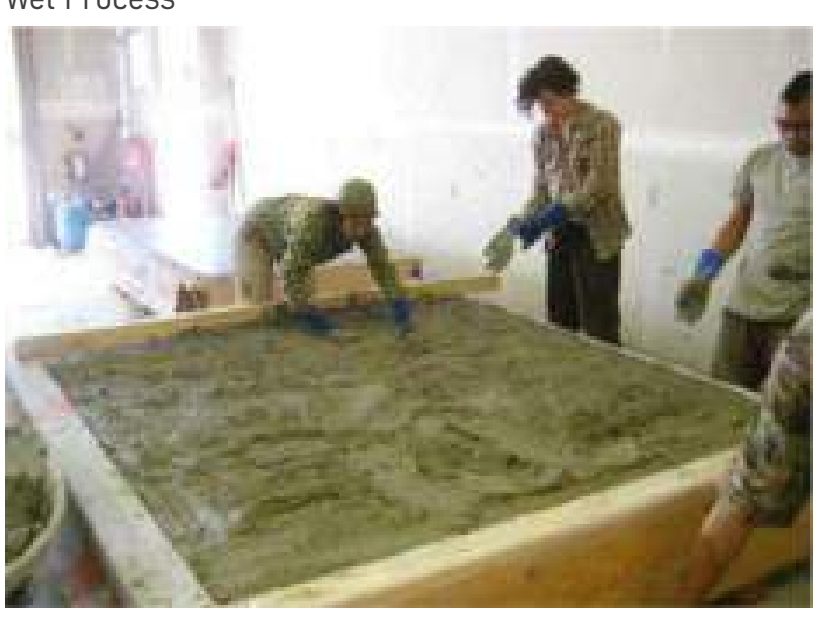

Reprinted From "Essential Prefab Straw Bale Construction: The Complete Step-by-Step Guide" by C. Magwood, 2016, p. 16. Copyright 2019 by Chris Magwood

\section{Figure 47}

Dry Process

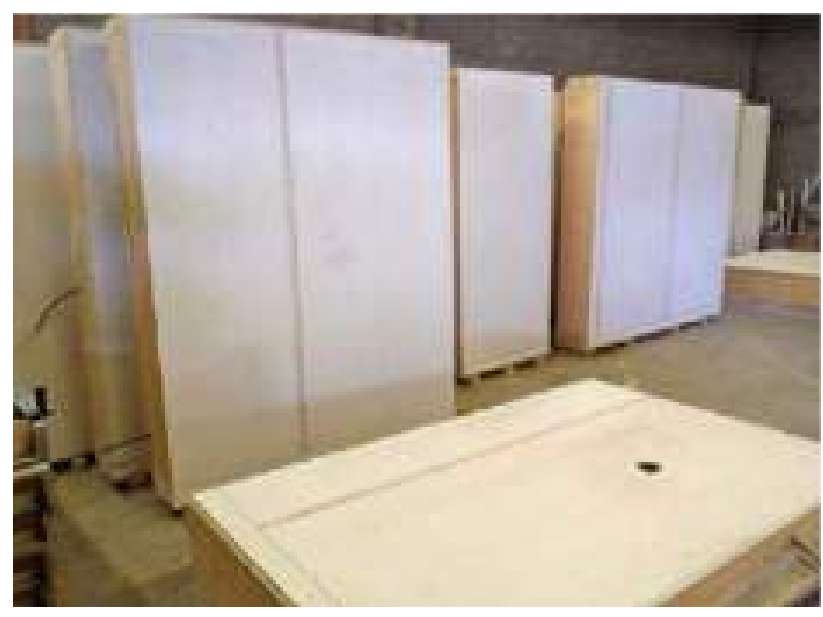

Reprinted From "Essential Prefab Straw Bale Construction: The Complete Step-by-Step Guide" by C. Magwood, 2016, 16. Copyright 2019 by Chris Magwood

A hollow timber box beam for the top and bottom plates minimises thermal bridging and provides separate cavities that require insulation (figure 48) (Magwood, 2016). This provides an opportunity for wool insulation within a straw prefabricated panel.

\section{Figure 48}

Insulated bottom plate

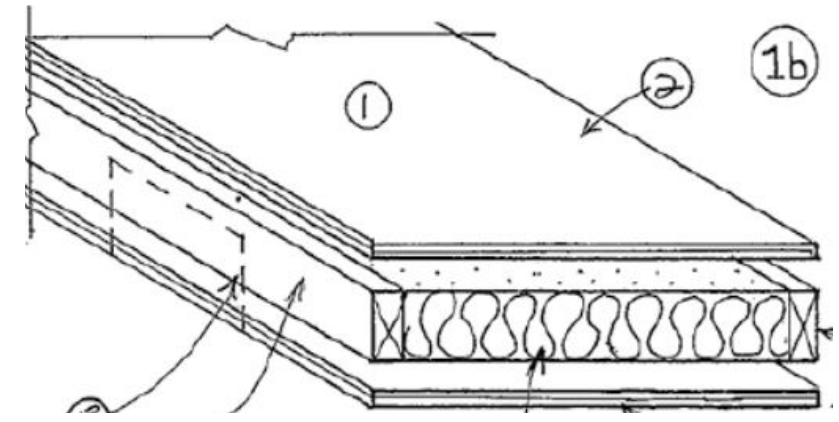

Reprinted From "Essential Prefab Straw Bale Construction: The Complete Step-by-Step Guide" by C. Magwood, 2016, p. 6. Copyright 2019 by Chris Magwood.

Ecopanel uses plywood, RAB board, or oriented strand board over wool blend insulation (figure 49) (Ecopanel, 2018). However, pure wool insulation without the added moisture resistance of the polyester is more susceptible to moisture damage, to a similar extent as straw, and therefore requires different treatment. Straw is hygroscopic which means it will absorb and store water (Kennedy et al., 2014). This means straw bales require a vapour-permeable construction to ensure there is reasonable drying potential (Racusin, 2012). Wool is also hygroscopic (Tuzcu,

\section{Figure 49}

Wool blend insulated Ecopanel

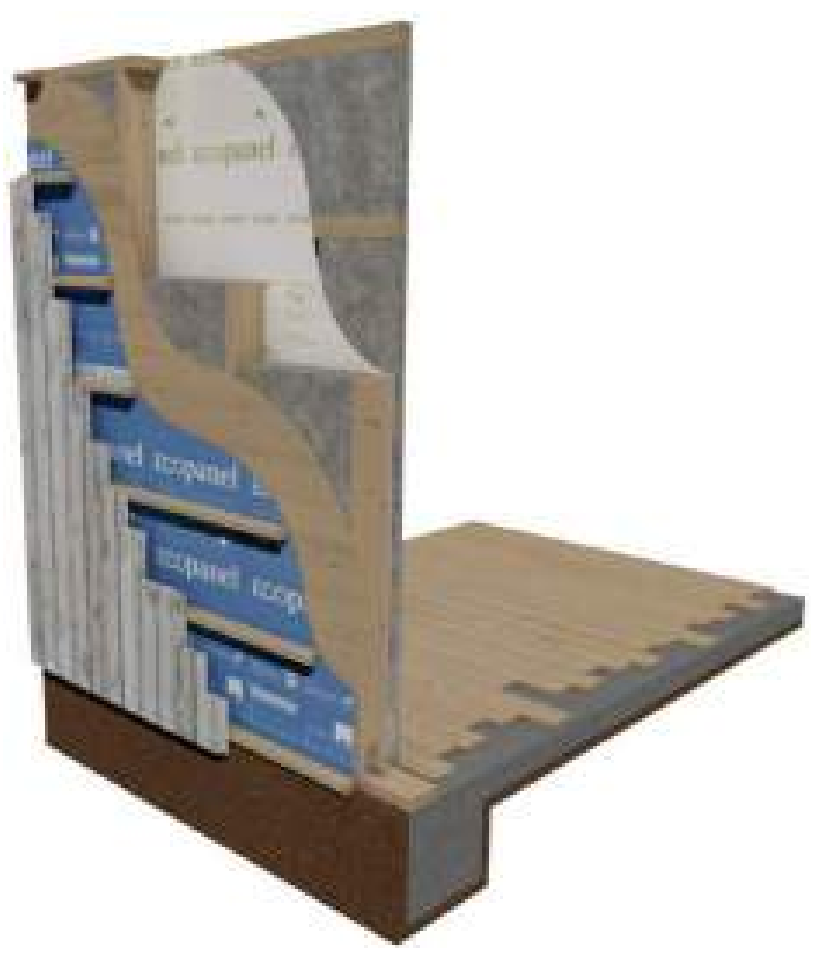

Retrieved from Ecopanel (https://www.ecopanelconz/ insulated-wall-panels) on 20 September 2020.
2007). A prefabricated wool wall panel should therefore be constructed in a similar manner to a straw wall pane and use a vapour-permeable sheathing as wool canno support a plaster render. Gypsum sheathing is the most suitable sheathing material for this purpose as it is mor vapour-permeable than a magnesium oxide sheathing (Magwood, 2016). Gypsum sheathing comes in two forms, one for exterior use featung a fiberglass and/or waxed paper coating and one for interior use (Magwood, 2016).

LVL panels are often used in prefabricated straw bale construction (Magwood, 2016). These timbers contain inorganic glues which slow down the biodegradation of the timber. However, these engineered timbers still biodegrade. New Zealand LVL is $43 \%$ degradable organic carbon which will decompose by $5 \%$ over 23 years (Love, 2010). Within timber framing, LVL has been rapidly taking share from pinus radiata timber in recent years in New LVL is available in New Zealand. 
Figure 50

Ecococon Panel

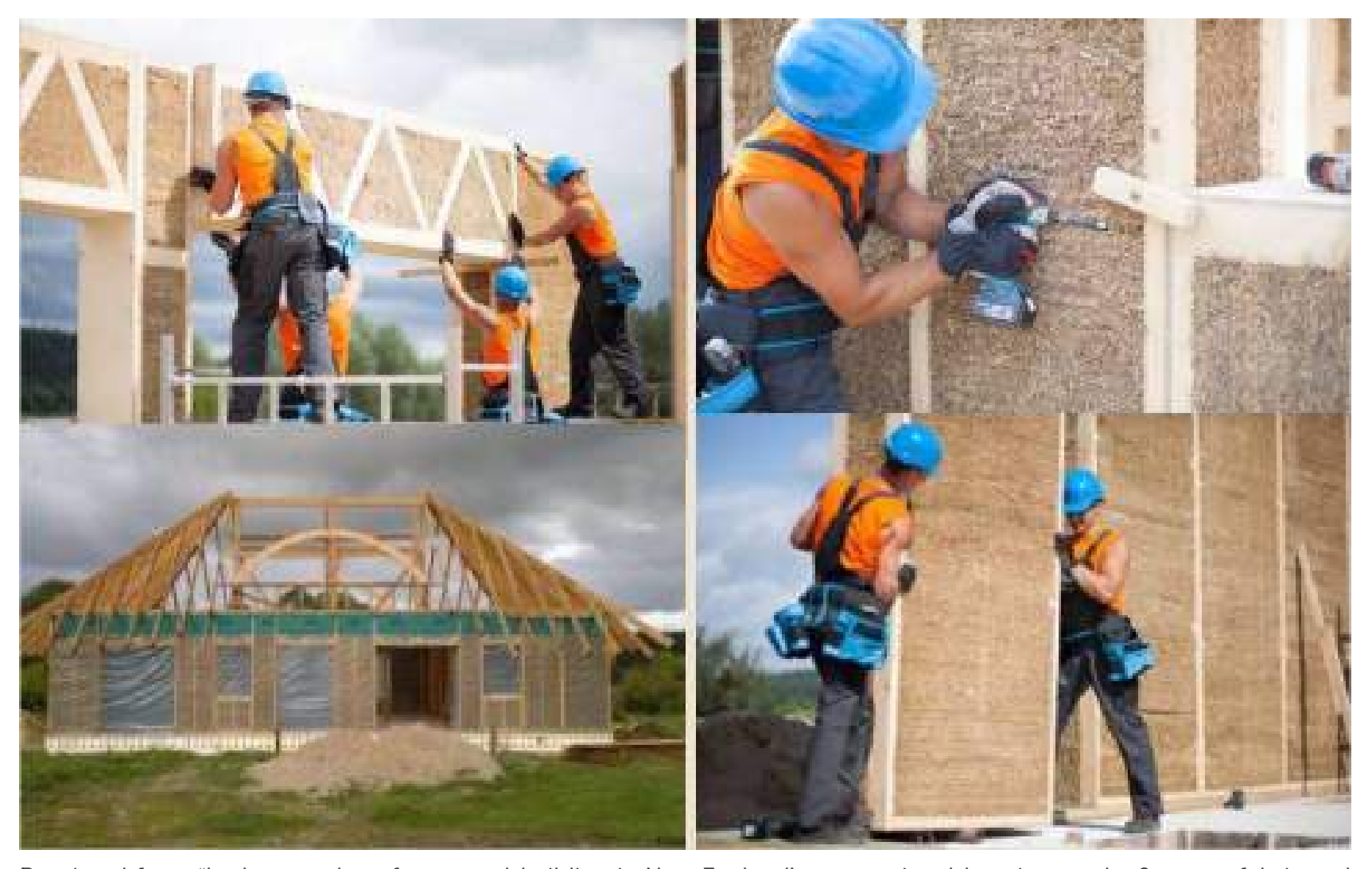

Reprinted from "Is there a place for natural building in New Zealand's conventional housing market? - a prefabricated straw bale case study" by M. Hall, 2014, Copyright 2014 by Min Hall.

\begin{tabular}{|l|l|l|}
\hline Description & Strengths & Weaknesses \\
\hline - Timber perimeter, double timber & - Compressed straw allows for & - Compressed straw is a more costly \\
frame, compressed straw infill & increased structural integrity, fire & and involved process than using \\
& resistance, pest resistance, flexibility & straw bales \\
& of scale & - Difficult to install services \\
& & - Thick walls to achieve sufficient \\
& R-value \\
& - Heavy \\
& - Thermal bridging through timber \\
& casing \\
& - Panels can't be deconstructed at \\
& the end of life due to continuous \\
& claddings over the exterior surface \\
\hline
\end{tabular}

Figure 51

Project Pātūtū NZ 2019

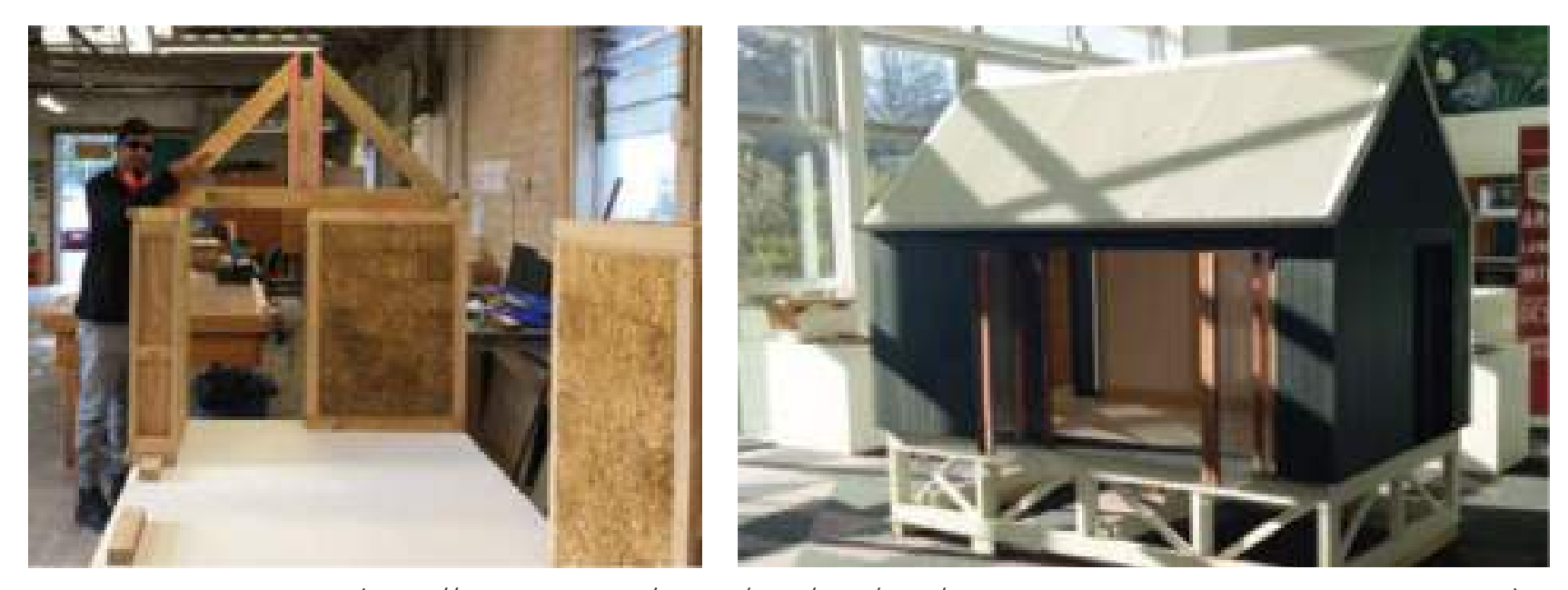

Retrieved from Far.org.nz (https://www.far.org.nz/assets/files/blog/files/97780f8e-8b07-5d41-a8e4-12b036a2ca97.pdf) on 30 June 2020

\begin{tabular}{|l|l|l|}
\hline Description & Strengths & Weaknesses \\
\hline - Timber perimeter, double timber & - Mini straw bales allow for lighter & - Mini bales are resized standard \\
frame, mini straw bale infill & thinner panels units \\
& - Mini straw bales allow for a more \\
& conventional wall thickness & - Difficult to instaces off-cut services \\
- Only moderate & thinner walls \\
& & $\begin{array}{l}\text { - Thermal bridging through timber } \\
\text { casing } \\
\text { - Size of bales dictates the size of the } \\
\text { panel }\end{array}$ \\
& & \\
\hline
\end{tabular}


Sol Design prefabricated straw bale panels New Zealand, 2014
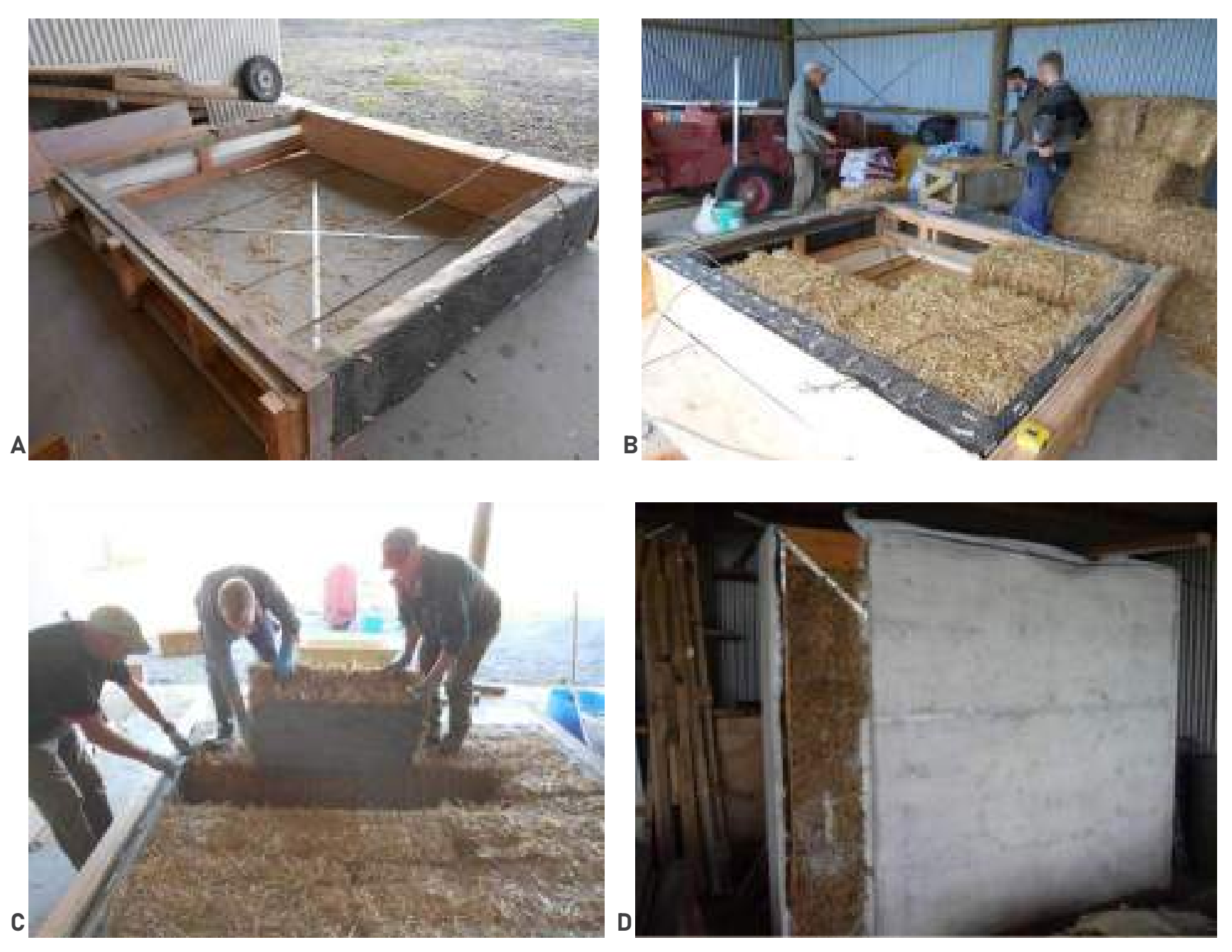

straw bale case study" by M. Hall, 2014, Copyright 2014 by Min Hall.

\begin{tabular}{|c|c|c|}
\hline Description & Strengths & Weaknesses \\
\hline $\begin{array}{l}\text { - Timber perimeter, double timber } \\
\text { frame, straw bale infill, cement } \\
\text { plaster }\end{array}$ & $\begin{array}{l}\text { - Services are pre-installed in the } \\
\text { panels }\end{array}$ & $\begin{array}{l}\text { - Cement plaster is non-biodegradable } \\
\text { and has lower vapour permeability } \\
\text { than clay or lime plaster } \\
\text { - Uses steel straps and steel mesh } \\
\text { - Thermal bridging through timber } \\
\text { casing and "buttered" bales } \\
\text { - Size of bales dictates the size of the } \\
\text { panel } \\
\text { - Heavy } \\
\text { - Thick walls }\end{array}$ \\
\hline
\end{tabular}

Figure 53

ModCell prefabricated straw bale wall panels

Modcelp Core

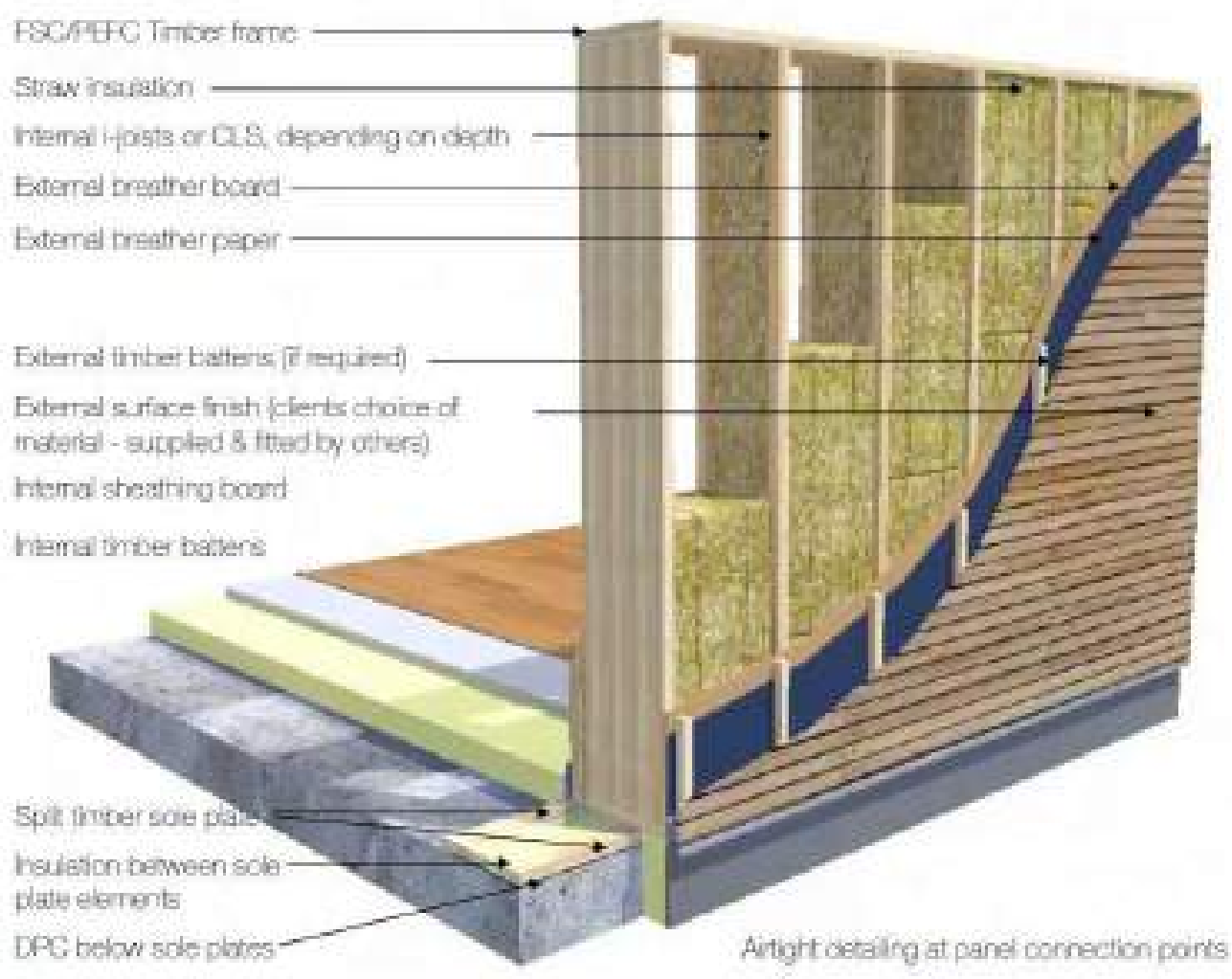

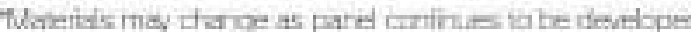

Reprinted from Modcell Technical Guide (https://www.modcell.com/files/3615/5066/3020/ ModCell_Technical_Guide_2019v2r.pdf) on 18 April 2020.

\begin{tabular}{|l|l|l|}
\hline Description & Strengths & Weaknesses \\
\hline - Timber perimeter, timber I beam & - Bales slot simply in between studs & - Timber cladding has lower vapour \\
studs, straw bale infill, timber & - Extra studs increases structural & permeability than clay or lime plaster \\
cladding & capacity & - Uses non-biodegradable such \\
& & materials such as DPC, synthetic \\
& insulation and external breather paper \\
& & - Non-biodegradable sealing tape is \\
& required to fix the panels together \\
& - Lots of Thermal bridging through \\
& vertical timber members \\
\hline
\end{tabular}




\section{Figure 54}

Straw into Gold, 2014

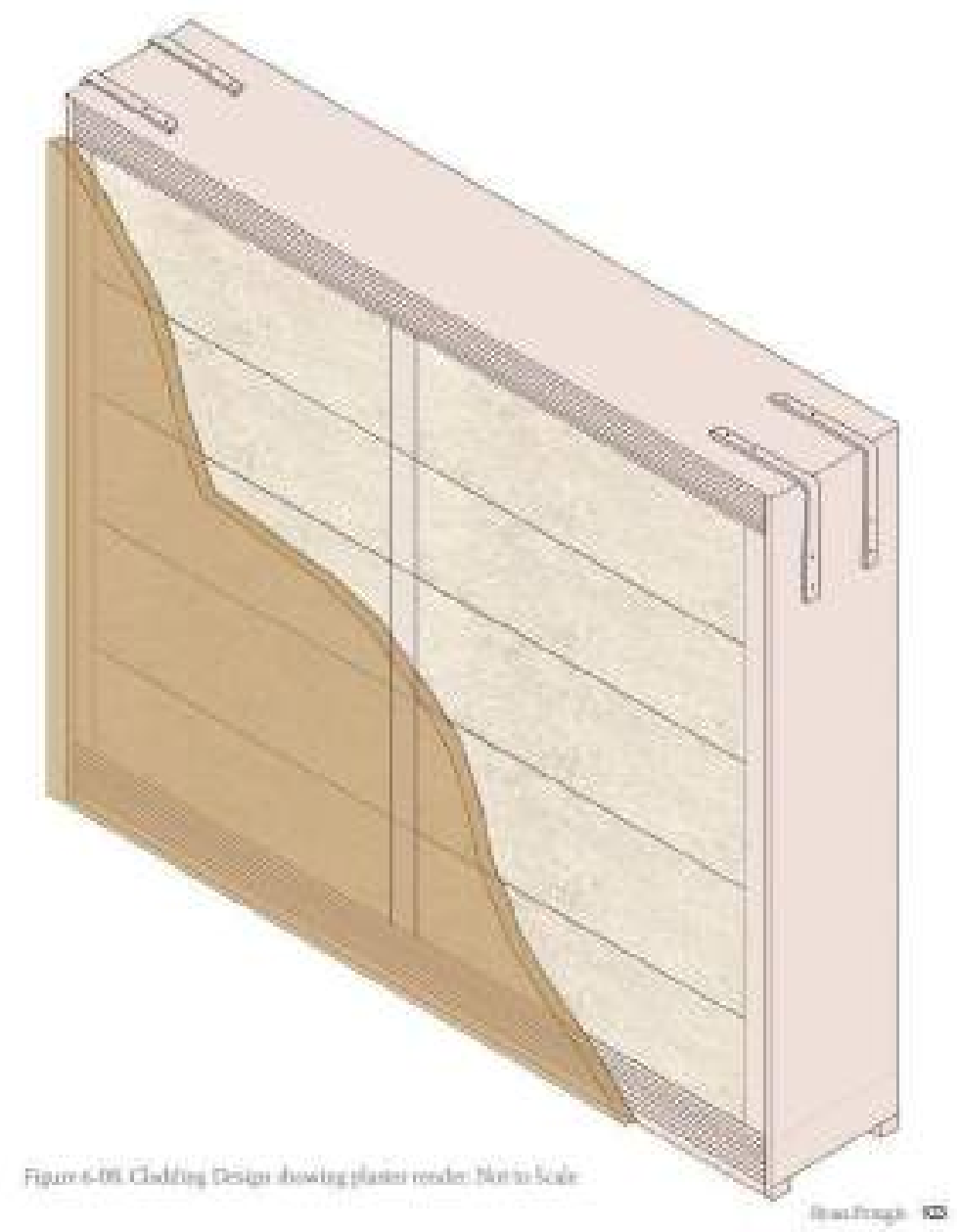

Reprinted from "Straw into gold" by R. Pringle, 2014, Copyright 2014 by Ryan Pringle

\begin{tabular}{|l|l|l|}
\hline Description & Strengths & Weaknesses \\
\hline - Timber perimeter, double timber & - Services are pre-installed in the & - Uses steel corner braces \\
frame, straw bale infill, clay plaster & panels & - Thermal bridging through timber \\
(Based off Modcell panel) & - Clay plaster has the highest vapour & casing \\
& permeability of any plaster & - Smaller panel size increase number \\
& - Lack of full depth studs eliminates & of joints required between panels \\
& thermal bridging & where there is high risk of leaks and \\
& - Smaller panels increases flexibility & air gaps \\
& of dwelling size & - Clay plaster has low durability \\
& - Smaller panel size increases & \\
& reusability potential as a module & \\
\hline
\end{tabular}

\begin{tabular}{|l|l|}
\hline General Issues & Learnings \\
\hline - Thermal bridging through timber elements & - Compressed straw has increased structural integrity, \\
- Exterior plaster renders only have moderate durability & fire resistance, pest resistance and flexibility of scale \\
- Exterior timber claddings have lower vapour permeability & - Pre-installed services are preferred as services are \\
than plaster renders & difficult to install in straw bale \\
- Difficult to install services & - Clay plaster has the highest vapour permeability of any \\
- Presence of non-biodegradable materials (Glues, & plaster \\
membranes, metal meshes) & - Lack of full depth studs eliminates thermal bridging \\
- Panels are non-deconstructable at end of life & \\
- Heavy & \\
- Thick & \\
- Panel size dictated by bales & \\
- No Wool Prefabricated panel & \\
\hline
\end{tabular}

\section{Design Proposals}

A prefabricated timber frame was used for each design. The prefabricated frame is based on the minimum straw bale width of $900 \mathrm{~mm}$ and depth of $350 \mathrm{~mm}$ and the minimum stud height of $2400 \mathrm{~mm}$. This was done for the sake of simplicity. The timber frame weighs $169.5 \mathrm{Kg}$. For each design, a pure wool batt insulation product that can hold its shape is proposed along with compressed straw.

Panel 1 is the timber frame filled with compressed straw insulation with wool insulation present in hollow timber box beams used for the bottom and top plates. Panel 2 is identical to panel 1 apart from $150 \mathrm{~mm}$ of pure wool insulation instead of straw in the centre. Straw is present on either side of the wool insulation as a substrate to support clay plaster. Rigid seff-supporting compressed straw panels will be glued into the prefabricated timber frame on one face before the pure wool batt insulation is laid in the frame and sandwiched between identical straw panels on the other face. Panel 3 is entirely insulated with pure wool batt insulation with gypsum sheathing on the exterior and interior.

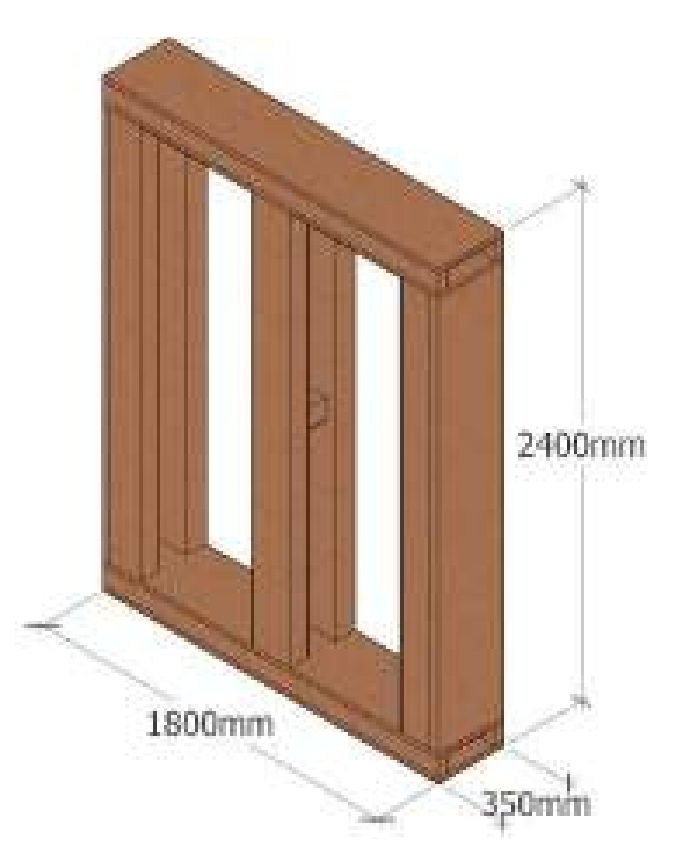




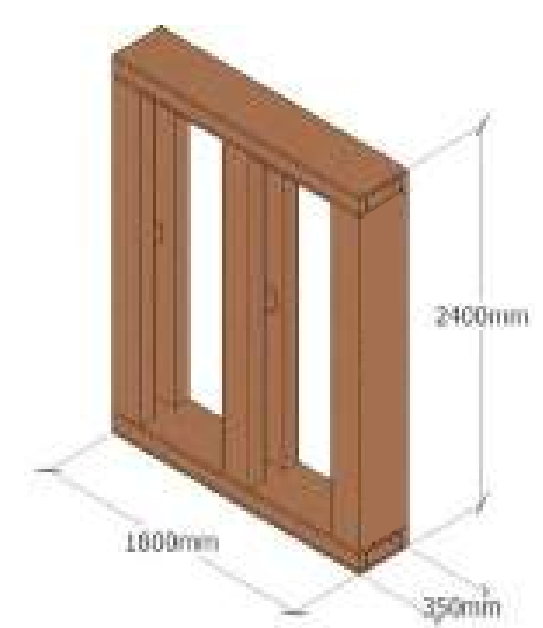

1. Prefabricated douglas-fir frame using douglas-fir dowel joints

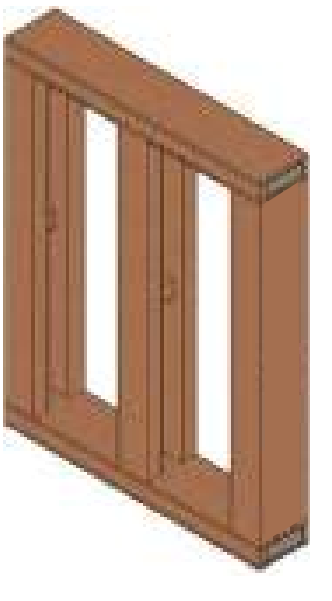

2. Pure wool batt insulation in cavities of top and bottom plate

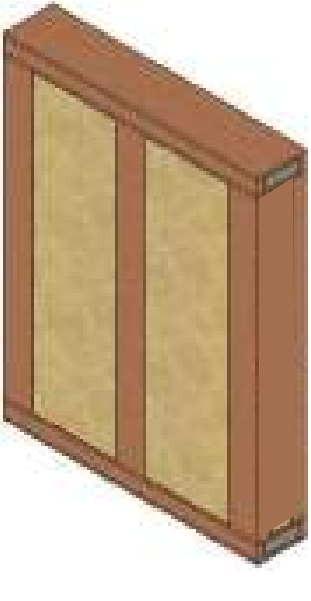

3. Compressed straw

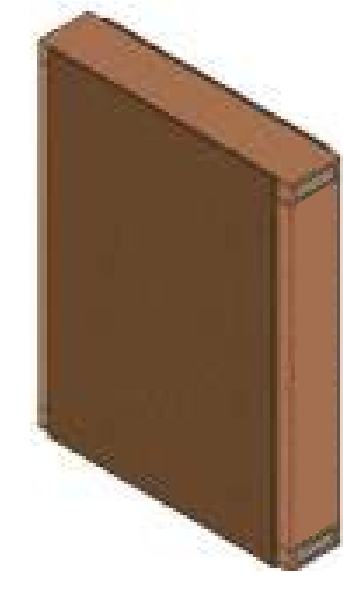

4. $25 \mathrm{~mm}$ clay plaster on both sides
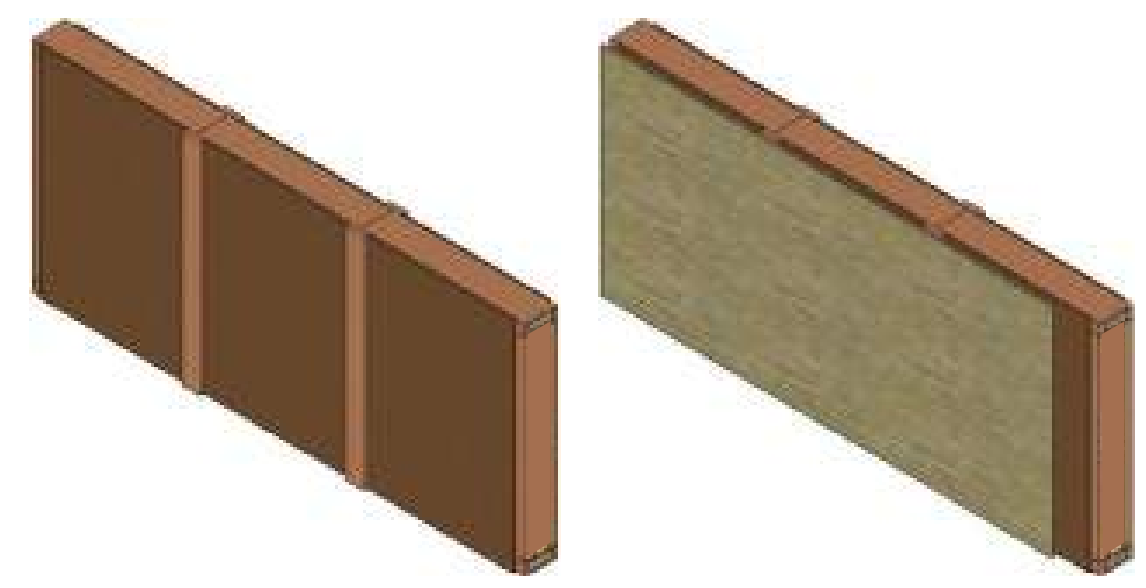
cavity to joining battens with douglas-fir dowels fir joining battens and douglas-fir dowels on both sides
6. Macrocarpa cladding fixed over

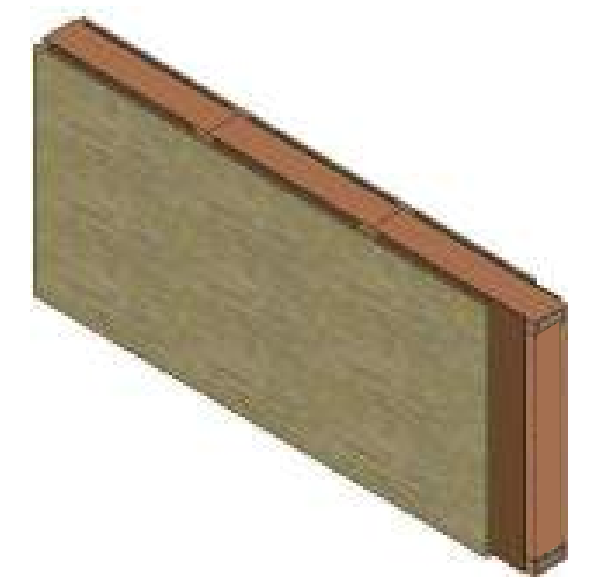

7. Optional fixing of interior lining to interior battens over cavity (cavity can be used for cabling)

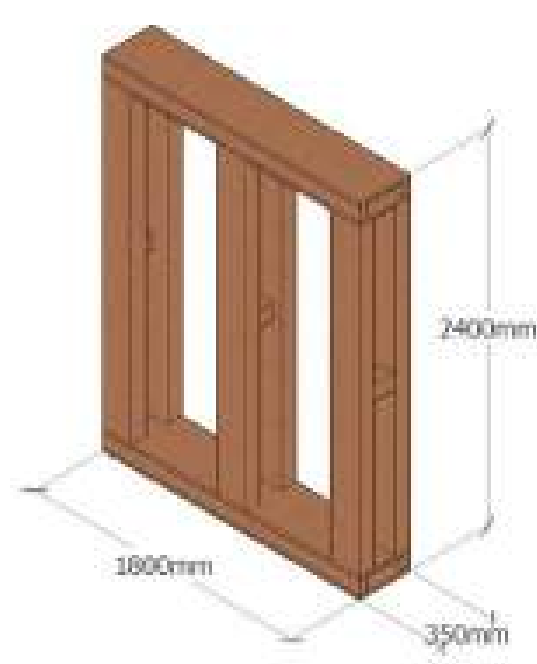
frame using douglas fir-dowel

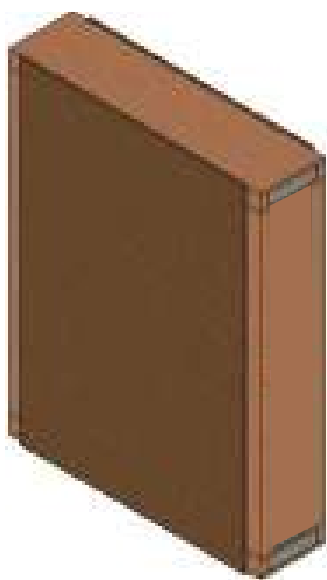

5. $2.5 \mathrm{~mm}$ clay plaster on both sides and fix douglas-fir side panels to the frame
1. Prefabricated douglas-fir
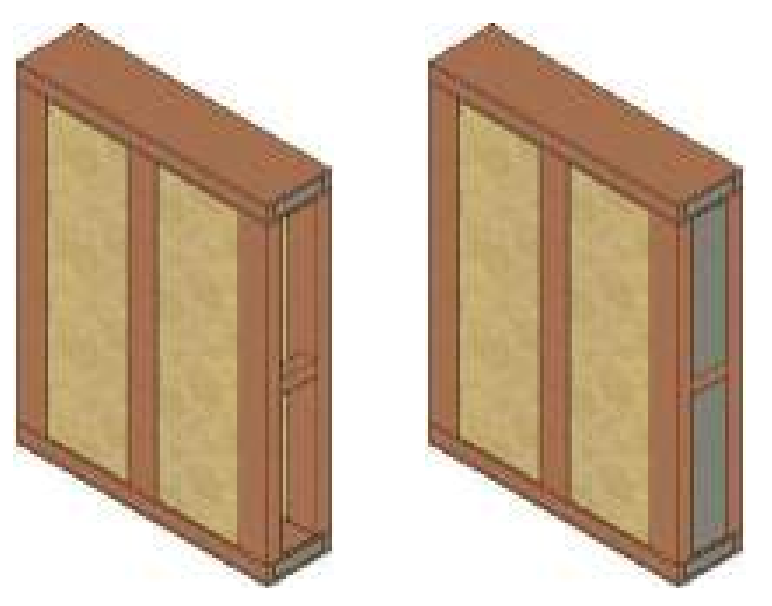

3. Compressed straw rigid panels $100 \mathrm{~mm}$ thick on both sides
4. Pure wool batt insulation, $150 \mathrm{~mm}$

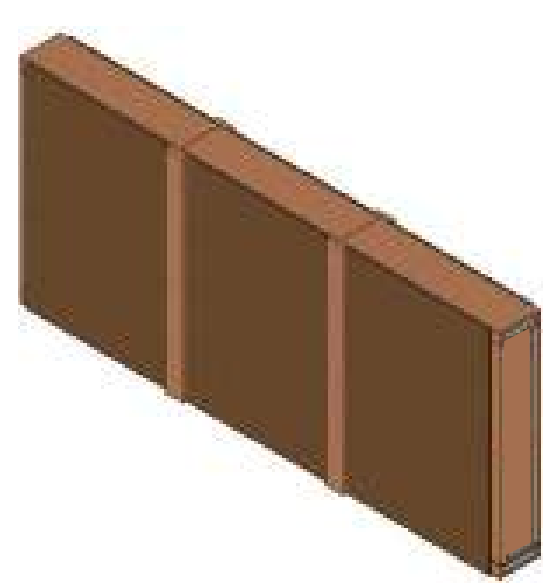

6. Fix panels together with douglas-fir joining battens and douglas-fir dowels

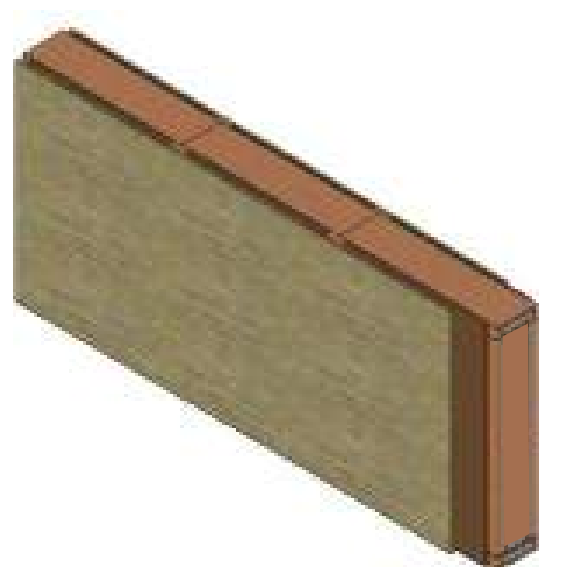

7. Macrocarpa cladding fixed over cavity to joining battens with douglas-fir dowels

8. Optional fixing of interior lining to interior battens over cavity (cavity 


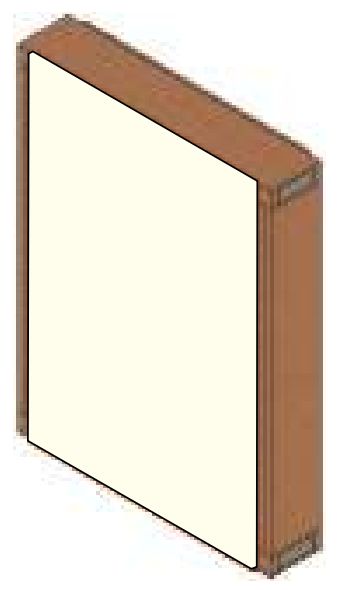

1. Prefabricated douglas-fir frame using douglas-fir dowel joints

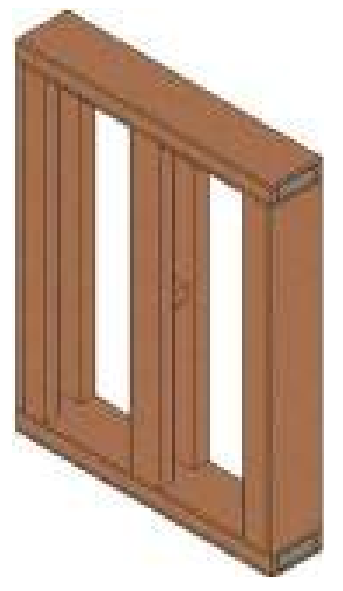

2. Natural wool batt insulation in cavities of top and bottom plate

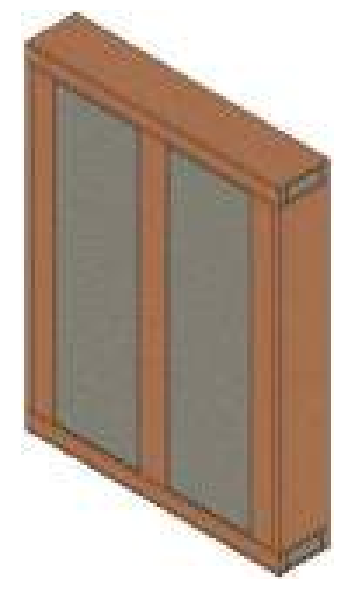

4. Pure wool batt insulation d on bo sides with screws

\section{Gypsum sheathing}

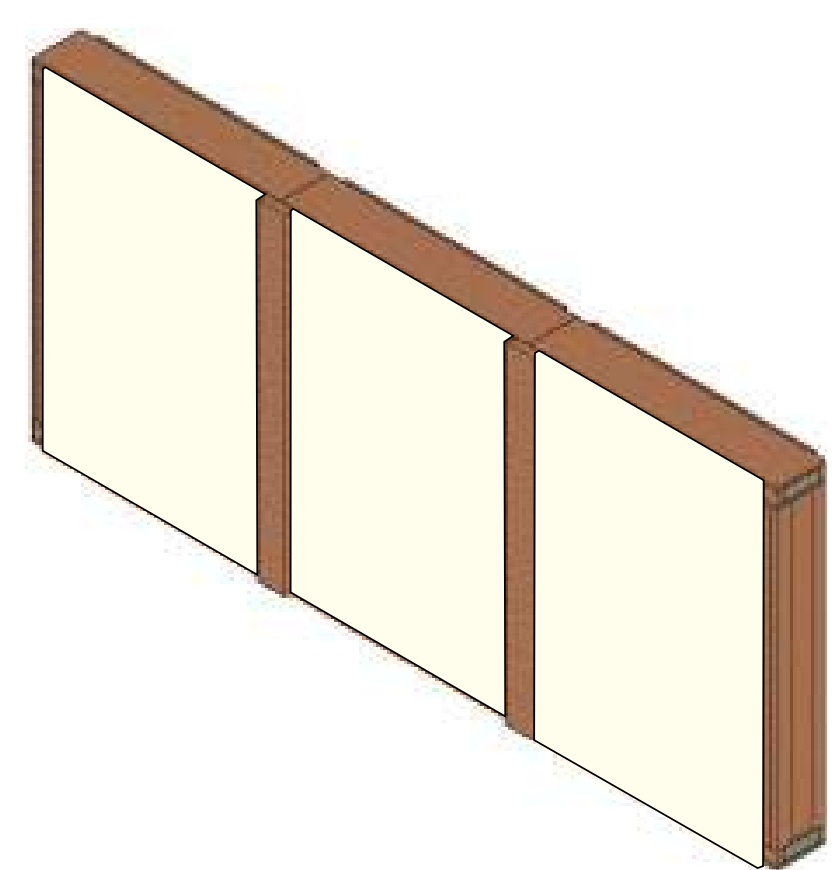

5. Fix panels together with douglas-fir joining battens and douglas-fir dowels

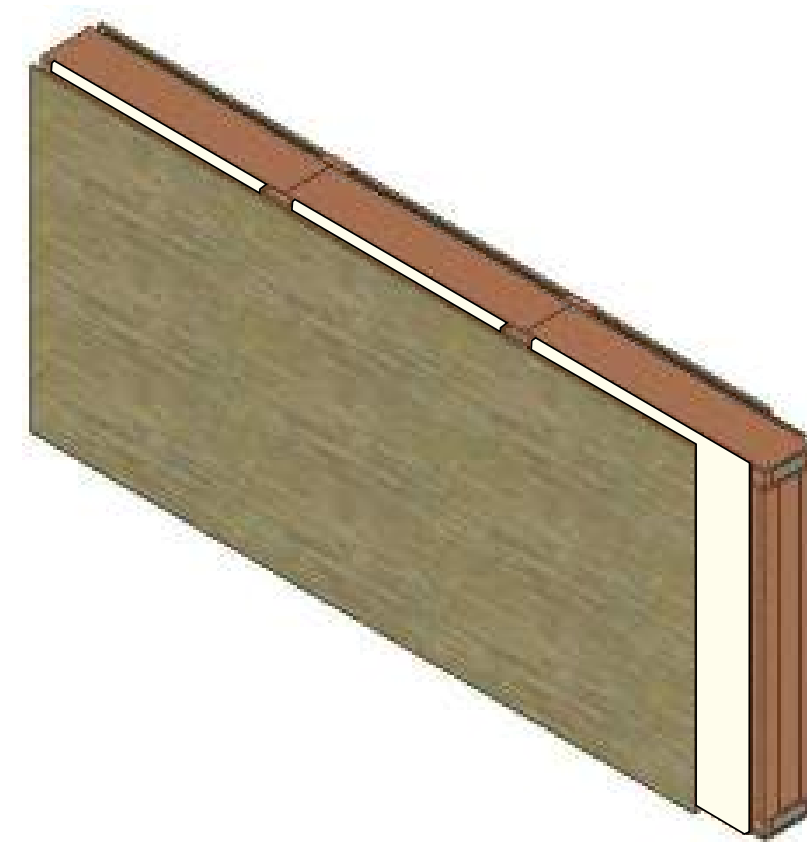

6. Macrocarpa cladding fixed over cavity to joining battens with douglas-fin

8. Optional fixing of interior lining to interior battens over cavity (cavity can be used for cabling)
Panel 1

Panel 2

Panel 3

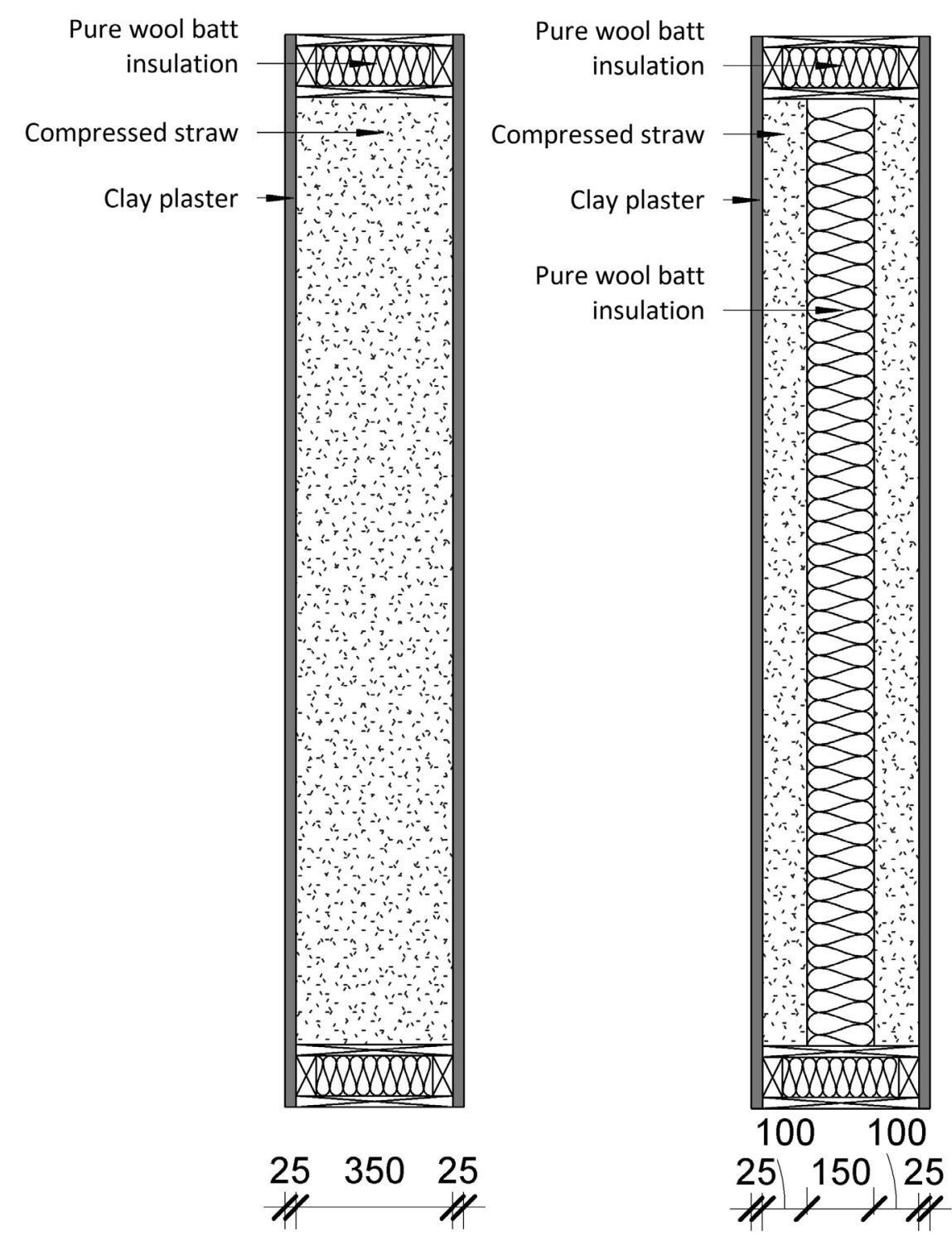

Properties of Panel Designs

\begin{tabular}{|l|l|l|l|}
\hline & Weight & Thermal Resistance & Vapour Resistance \\
\hline Panel 1 & $582.3 \mathrm{Kg}$ & $7.2 \mathrm{~m}^{2} \mathrm{~K} / \mathrm{W}$ & $4.716 \mathrm{MNs} / \mathrm{g}$ \\
\hline Panel 2 & $528.1 \mathrm{Kg}$ & $8.7 \mathrm{~m}^{2} \mathrm{~K} / \mathrm{W}$ & $4.757 \mathrm{MNs} / \mathrm{g}$ \\
\hline Panel 3 & $273.8 \mathrm{Kg}$ & $10.8 \mathrm{~m}^{2} \mathrm{~K} / \mathrm{W}$ & $4.774 \mathrm{MNs} / \mathrm{g}$ \\
\hline
\end{tabular}




\section{Discussion}

Panel 1 only makes a minor alteration on existing prefabricated straw panels such as Ecococon and ModCell ${ }^{\otimes}$ with the addition of pure woot insulated top and bottom plates. Panel 1 is, therefore, the least speculative of the 3 designs and has the most potential for realworld application. Panel 2 combines wool's low density and superior insulative properties with straw's ability to support the bio-based vapour permeable material of clay plaster. It is, therefore, more insulative than panel 1 and more vapour permeable than panel 3.

Panel 2 occupies a useful middle ground in terms of vapour and thermal resistance. The presence of the clay plaster on both panels land 2 does make the panels significantly heavier however a crane will be necessary even without this additional weight.

Panel 3 is a pure wool insulated substitute for the Ecopanel.

As expected, panel 3 is the lightest and most insulative of the 3 designs due to the exclusive use of pure woo insulation. However, panel 3 forgoes tolal biodegradabilty and the ability to support clay plaster resulting in a mild reduction in vapour permeability compared to panels and 2. The panels can support a timber rain screen over a vented cavity to improve weather resistance. These designs will be competing with many existing SIPs already available in NZ that do not use bio-based insulation materials.

Despite the thermal advantages and reduced weigh of panels 2 and 3 , panel 1 has the greatest potential for success. Panel 1 is the closest to successful real-world designs from Ecococon and ModCell $\Theta$. Without physica prototypes to demonstrate the effectiveness of panels 2 and 3 , which are inventive but stil speculative, panel 1 presents the most reliable path forward.

\subsection{Review of Construction Approaches}

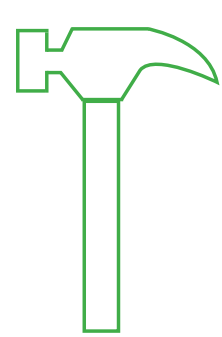

1. In-situ

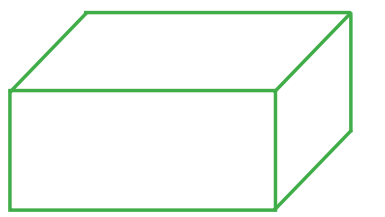

2. Standardised block Modules

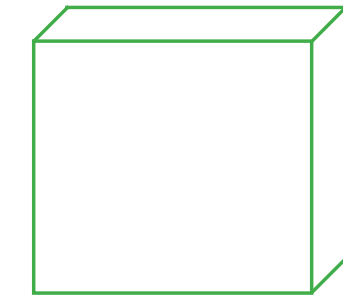

3. Prefabricated Panels
Construction approach review

\begin{tabular}{|l|l|l|l|}
\hline $\begin{array}{l}\text { Most successful strategy in } \\
\text { increasing } \\
\text { the uptake of biodegradable } \\
\text { materials }\end{array}$ & Greatest reuse potential & $\begin{array}{l}\text { Closest to NZ mainstream } \\
\text { construction practice }\end{array}$ & \\
\hline 1. Prefab & 1. Modules & 1. In-situ & 3 points \\
\hline 2. In-situ & 2. Prefab & 2. Prefab & 2 points \\
\hline 3. Modules & 3. In-situ & 3. Modules & 1 point \\
\hline
\end{tabular}

Most successful strategy in increasing the uptake of biodegradable materials

Prefabricated panels have the greatest potential to increase the uptake of biodegradable building materials followed by in-situ construction and standardised block modules. The Ecococon and ModCell panels demonstrate the success a prefabricated panel with bio-based insulation can have. Ecococon has built over 100 projects in the last 10 years (Ecococon, 2020). ModCell $₫$ has built 33 projects since 2001 (ModCelle, 2020). Conventional in-situ construction has produced all of New Zealand's biodegradable bullangs so far. However, this has not been at the rate achieved by Ecococon overseas. Standardised block modules are increasingly being studied but are yet to enter mainstream construction (Galle et al., 2017). This construction approach herefore has the lowest potential of increasing the uptake of biodegradable materials.

\section{Greatest Reuse Potential}

Standardised block modules have the greatest reuse potential followed by prefabricated panels and in-situ construction. Due to the standardised dimensions and demountable nature of the block modules its reusability is the greatest. The prefabricated panels come in a range of sizes which increases design flexibility but decreases the reusability potential compared to the standardised block modules. This is because a prefabricated panel needs a specific application to be reused instead of a general application like a standardised module. For In-situ construction only the reuse of individual deconstructed elements is possible. This makes the application for reuse even more specific than that required for a range of prefabricated panels.

\section{Closest to Mainstream Construction}

\section{Practice}

In-situ construction is the dominant construction technique in NZ. Prefabricated panels and standardised prefabricated construction modules occupy the vast minority of the market with standardised prefabricated modules occupying the smallest share.
Most suitable zero waste construction approach for New Zealand

\begin{tabular}{|l|l|}
\hline Construction Approach & Total Points \\
\hline 1. Prefab & 7 points \\
\hline 2. In-situ & 6 points \\
\hline 3. Modules & 5 points \\
\hline
\end{tabular}

With all these criteria considered prefabricated panels are the most suitable zero-waste construction approac for New Zealand 
Form Exploration
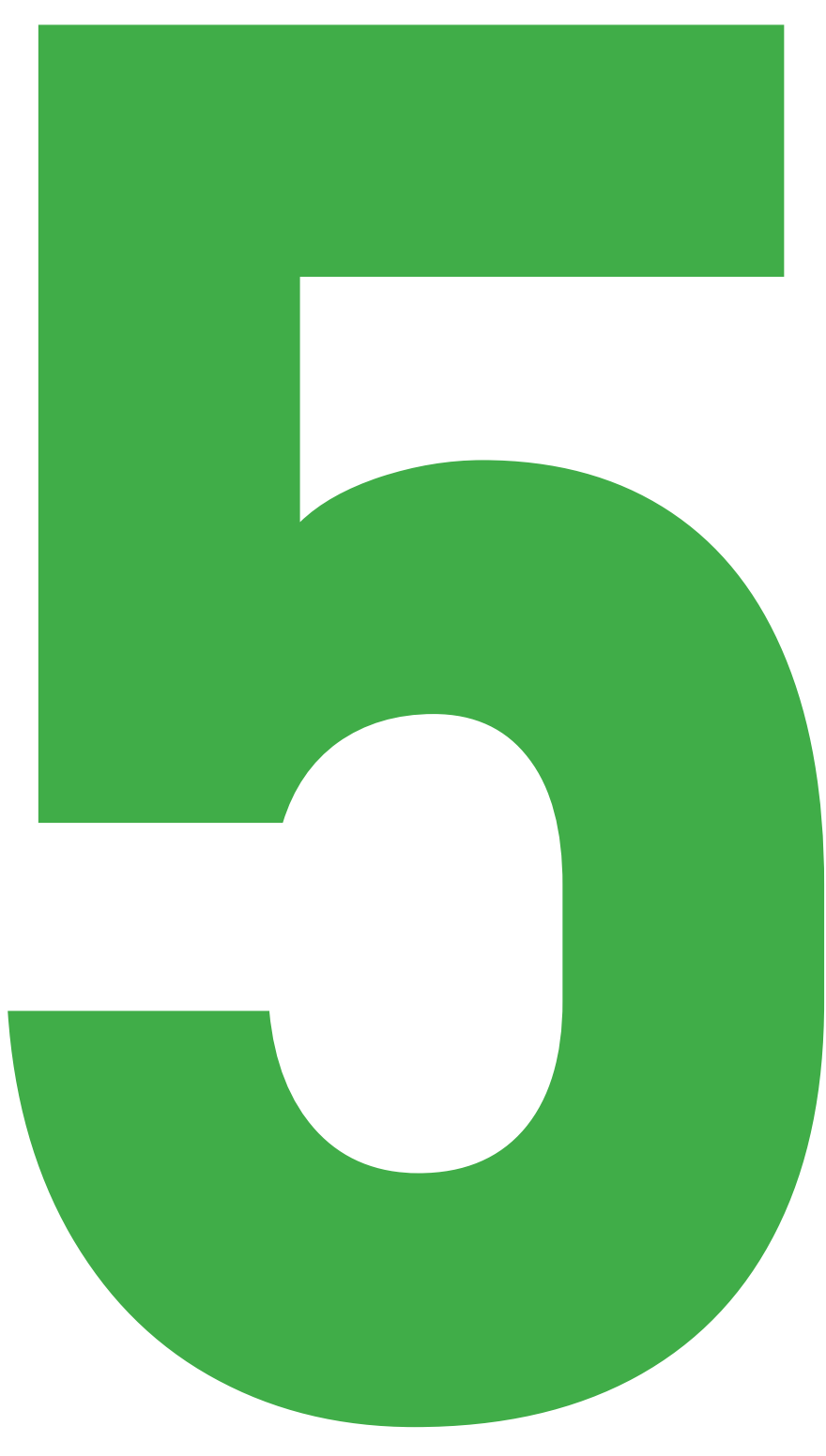

\section{Chapter Outline}

The previous chapter pursued the optimum zero-waste construction approach for New Zealand. This chapter primarily seeks a formal design that supports the use of biodegradable building materials and secondly a suitable medium density housing design. The integration of the design concept on site and detailed design 0 ccurs later in chapters 6 and 7 respectively. Biodegradable building design and medium density housing design were researched firstly to inform the design concepts. Design precedents were also used to inform and inspire each concept. Three concept designs were produced in an iterative design process where each design is reviewed to inform the next. The three concept designs are compared and reviewed at the end of the chapter in terms of their formal simplicity (exterior junctions/dwelling) and dwelling density (bedrooms/hectare). Formal simplicity is desirable for construction with biodegradable insulation such as wool or straw that are susceptible to moisture damage, as complex exterior junctions where leaks may occur are reduced. Formal simplicity is used as an assessment criterion for the first objective regarding the support of biodegradable materials, and dwelling density is used for the second objective regarding medium density housing. The most successful design concept is then selected for integration on site in the next chapter.

\section{Chapter Objectives}

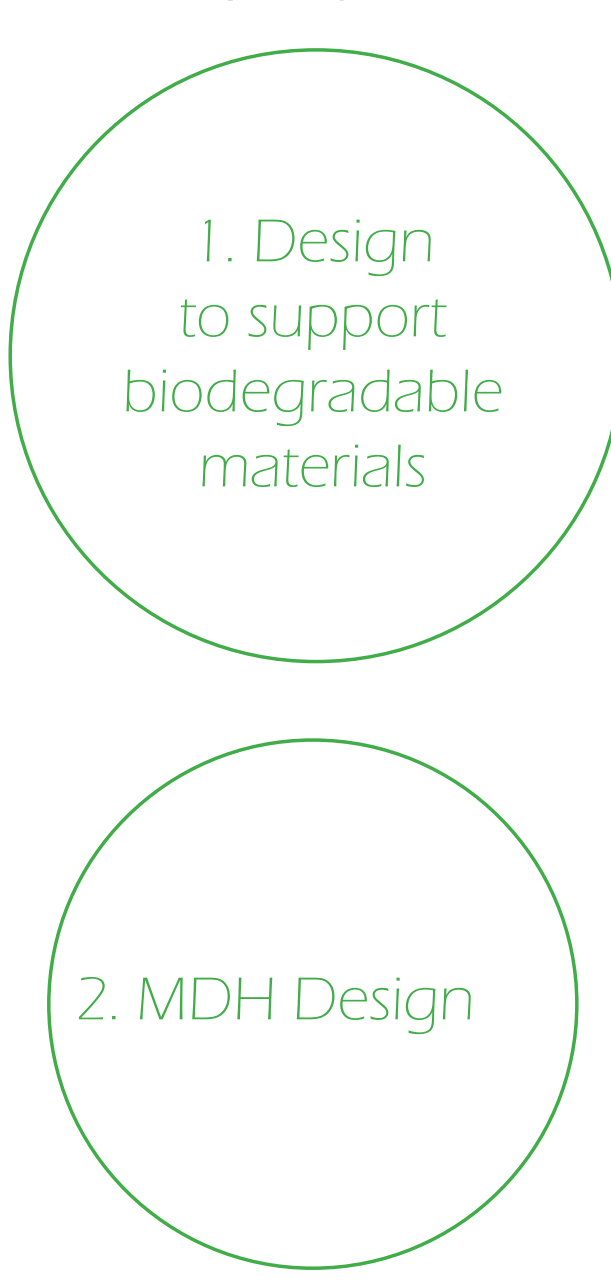

Biodegradable Building Design

Research

Many biodegradable buildings have been built by natural builders and many of them fail due to poor moisture management. Many straw bale buildings have failed using cement plaster which is non-vapour permeable and traps moisture within the construction (Kennedy et al., 2014). Moisture is the nemesis of biodegradable materials as it can cause premature decomposition. This is particularly true for biodegradable insulation materials including straw and wool used in this thesis. It is widely known that a straw bale building must be designed and constructed in such a manner that the straw remains dry throughout (North, 2002).

Some foundational design strategies have therefore been developed by natural builders to keep the rain away from the building and prevent excess moisture infiltrating the insulation. The roof is the primary means of achieving this as it is the first line of defence against moisture. Steep roofs with large overhangs are used to shed rain and minimise the exposure of the external walls (BRANZ, 2015). In straw bale construction this is often referred to as a "good hat" (Racusin, 2012). Shortly after the arrival of European settlers to New Zealand roofs were made with large eves to protect cob walls from rain (Salmond, 2010). In addition, roofs were also steep, often at least 30 degrees, to shed rain, and in the South Island even steeper roofs were preferred to shed snow (Salmond, 2010).

In straw bale construction a bulding not only needs a "good hat" but also "good boots" (North, 2002). This refers to a means of preventing moisture from entering the construction from the ground (Kennedy et al., 2014). This can be achieved by suspending the structure off the ground or using a thick non-porous foundation such as stone or concrete to give good separation between the ground and the vulnerable construction (Racusin, 2012).

With this understood, each design concept will therefore have a steep roof with large overhangs. This also supports the use of timber shingles (found to be the most suitable roofing materials in chapter 3 ) which are more effective at keeping moisture out at steeper angles. Each design will also be suspended off the ground through the use of reusable concrete foolings (one of the most suitable foundations approaches found in chapter 3 ). 
Medium Density Housing Design Research

There is no universally agreed-upon definition of Medium Density Housing (BRANZ, 2017b). For this project, however. clarity of definition is not essential if its position on the density spectrum is understood Medium-density housing (MDH) sits between low-density housing (LDH) and high-density housing $(\mathrm{HDH})$ on the density scale. In New Zealand, LDH includes stand-alone dwellings, generally 1-2 storeys, on independent sections typically between 400-800m2 (BRANZ, 2017b). HDH includes apartment buildings greater than 6 storeys (BRANZ, 2017b).

Medium-density housing has many typologies, including 1-storey units, 1-2-storey duplexes or triplexes, 2-4-storey terraced houses, and 3-6-storey apartments (BRANZ, 2017b). BRANZ divides these into three main categories (figure 55). The architectural typology of medium density housing was selected for this thesis for the purpose of constructing a 3-storey residential building that would

\section{Figure 55}

Medium density housing categories

\section{Category 1}

1-2-storey attached houses

- Subcategory A: Single-storey units

- Subcategory B:1-2-storey duplexes or

triplexes and semi-attached terraced

houses

\section{Category 2}

2-4-storey attached houses

- Subcategory C:2-storey terraced houses

- Subcategory D: 3-storey terraced houses

- Subcategory E: 4-storey terraced houses

\section{Category 3}

Apartments

- Subcategory F: 3-6-storey apartments

Figurel. Categories of medium-density housing.

Reprinted from "What is medium-density housing?" by BRANZ, 2017, Copyright 2017 by BRANZ. push the limits of biodegradable materials. Therefore, terraced housing or apartments are the only available typologies.

Surveys of NZ housing aspirations indicate the desire for the standalone home, including a private garage an backyard, as a preferred dwelling model and life-style (Bryson, 2017). This relates back to the 19th century when settlement promoter's advertised New Zealand with a rur vision - an image supported by the NZ Government well into the 20th century (Ferguson, 1994). New Zealanders also prefer a security and privacy-focused concept of safety rather than a community-focused one (BRANZ, 2017a). With this considered, a 3-storey apartmen instead of 3 -storey terraced housing would be preferable because the bulldings can be separated giving more yard space, increasing security and privacy, and providing the

Apartments are usually 1-2 storey self-contained housing units within a larger building (Ministry for the Environmen 2012. There is usually common access to a core stairwell and private open space is a courtyard or garden on the

\subsection{Concept 1}

\section{Precedent Review}

\section{Figure 56}

King Tāwhiao's whare at Te Kūiti, 1885

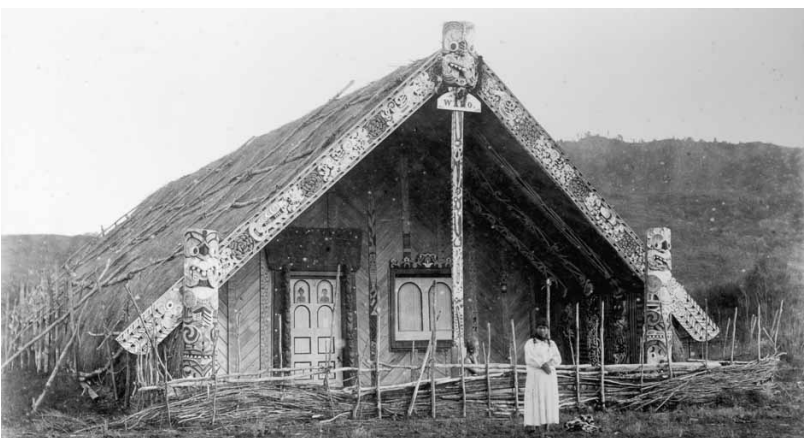

Retrieved from NZ Historu (https://nzhistory.govt.nz/ media/photo/king-tawhiaos-whare-at-te-kuiti) on 15 May

\section{Figure 57}

Japanese Kirizuma Straw Roof

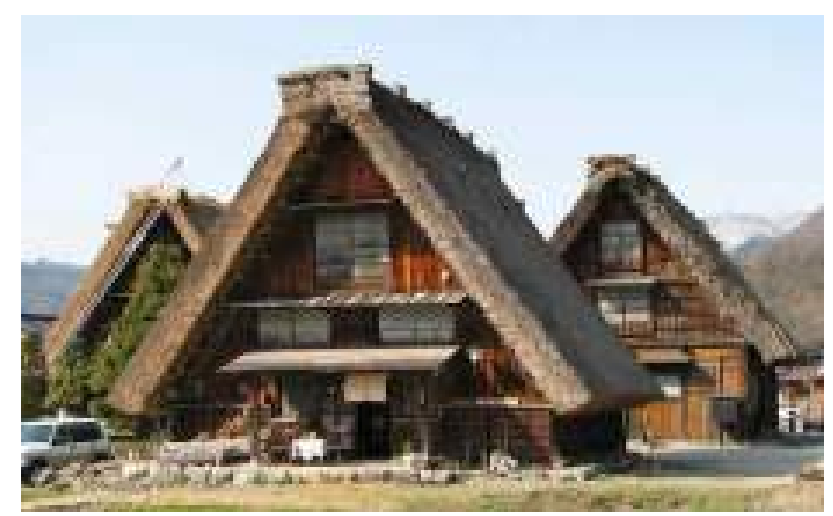

Retrieved from Bambubuild (http://www.bambubuild com/ n/traditional-roof-in-japanese-architecture/) on 15 May 2020

King Tāwhiao's whare (figure 56) is an example of biodegradable mâori vernacular architecture with a large steep roof. The Japanese kirizuma straw roof (figure 57) is a vernacular example of how a habitable space can be created under a large roof in an A-frame concept.
Figure 58

Straw Panel House, Poland, by LORENS Architects

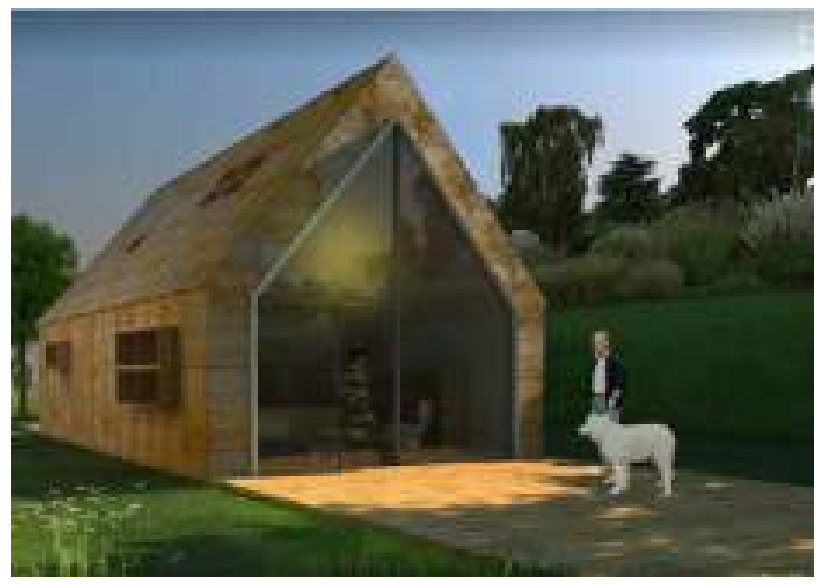

Retrieved from Archello (https://archello.com/story/9705/ attachments/photos-videos/1) on 16 May 2020

Figure 59

Nest, France, 1984

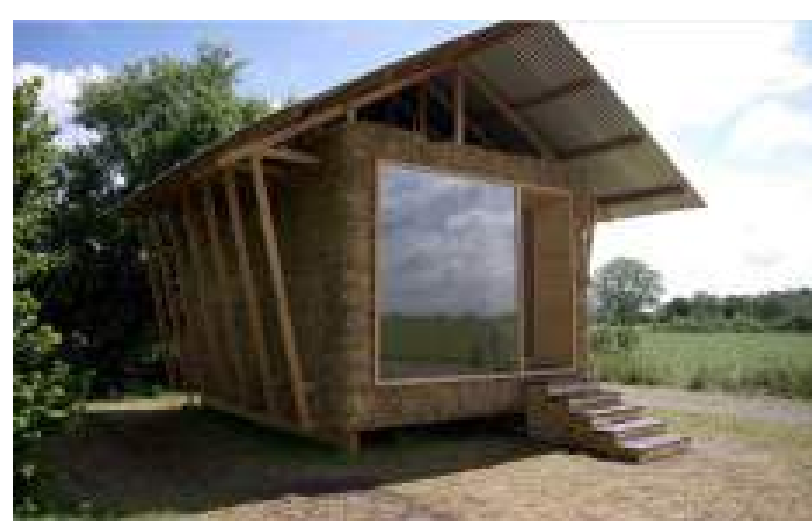

Retrieved from New Atlas (https:/newatlas com/nesthouse-studio-1984/25134/) on 16 May 2020

The Straw Panel House (figure 58) and Nest (figure 59) are both contemporary designs using straw. The Straw Pane House demonstrates the potential for skylights through thick straw bale walls and the pleasant aesthetic provided by the depth of the windows. Nest demonstrates the beauty of having the roof as a visually detached element and the benefit of improved access for maintenance that it provides 


\section{Straw Biod, Austria, 2019}
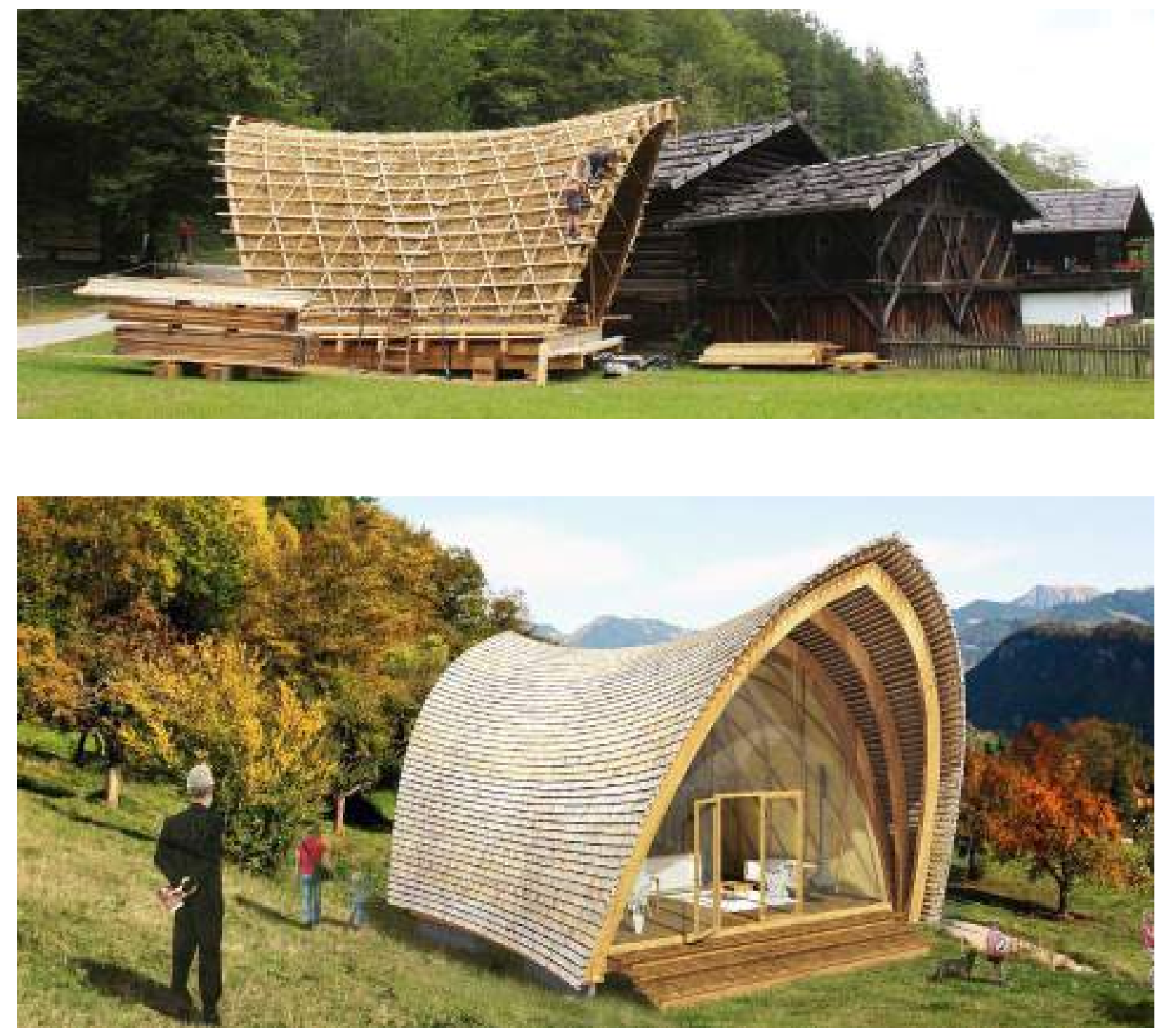

Photographs and renders by Straw boid, 2019. Retrieved from Detail (https://www.detail.de/artikel/strohboidKlimufreundliches-strohhaus-34813) on 17 April 2020. Last Updated 17 October 2019.

Straw boid is the primary precedent for this concept. It uses the same materials that were found to be the most suitable biodegradable materials in chapter 3 of untreated timber, straw bales and clay plaster, and does so in an innovative manner

The straw boid prototype was designed by architecture students Fritz Walter and Max Schade in their diploma thesis from the Institute for Structural Design at Graz University of Technology (Sigmund \& Mijatovic, 2019). The prototype consists of a wooden structure that can be completely dismantled at the end of life and either be reused or left to biodegrade (Sigmund \& Mijatovic, 2019). The timber structure is double layers to allow straw bales to slot in and occupy the voids (Sigmund \& Mijatovic, 2019). The curved wood is achieved by moistening and heating the wood with water vapour which liquifies the lignin (plant-based) glue allowing it to be shaped (Sigmund \& Mijatovic, 2019). A $25 \mathrm{~mm}$ layer of clay plaster coats the straw bates on the interior to preserve and fireproof the bales (Sigmund \& Mijatovic, 2019). An exterior layer of construction (Sigmund \& Mijatovic, 2019).

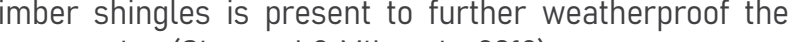

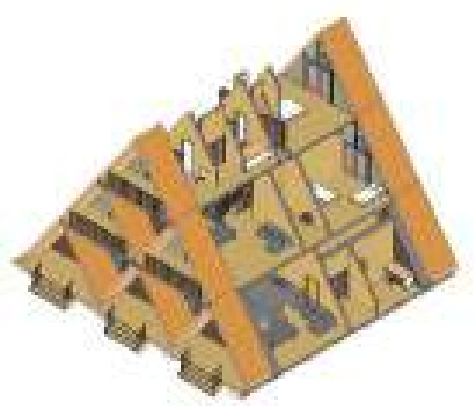

No slanted straw walls

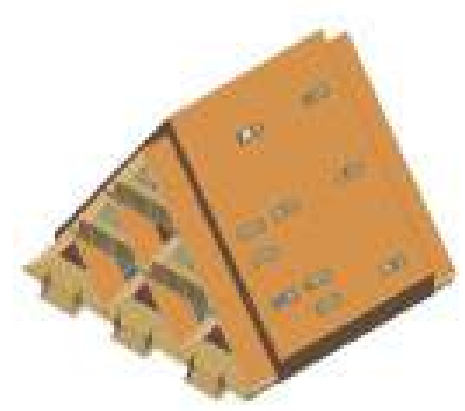

With slanted straw walls

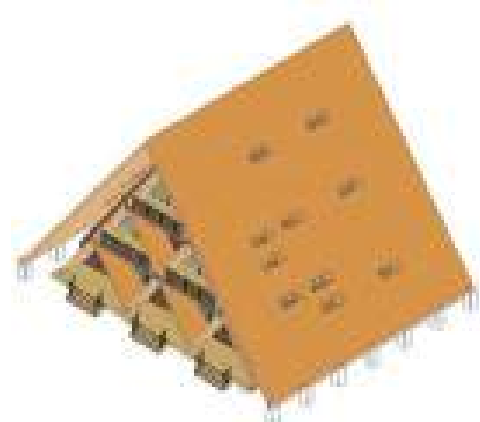

With added timber roof layer
Front + Rear Elevation 1:200

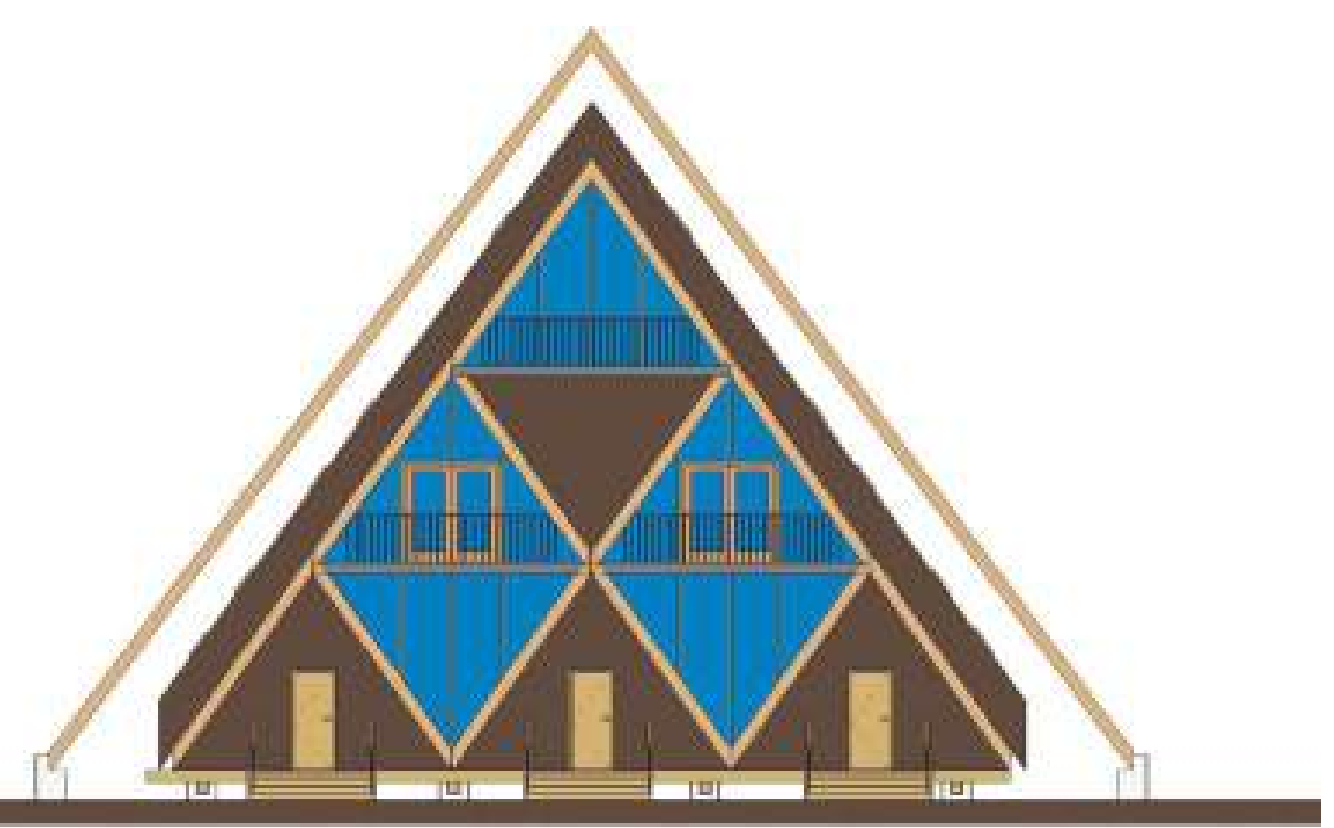

Because the research revealed the importance of having a "good hat", the roof became the driving feature of this design. An A-frame form was arrived at similar to the Japanese kirizuma straw roof precedent. The skylights design's envelope and the roof from the Nest precedent inspired the secondary detached roof layer. Timber shingles are used on the exterior and glazing is used on the front and rear facades in reference to the straw boid from the Straw Panel House inspired the apertures in the 
Side Elevation 1:200

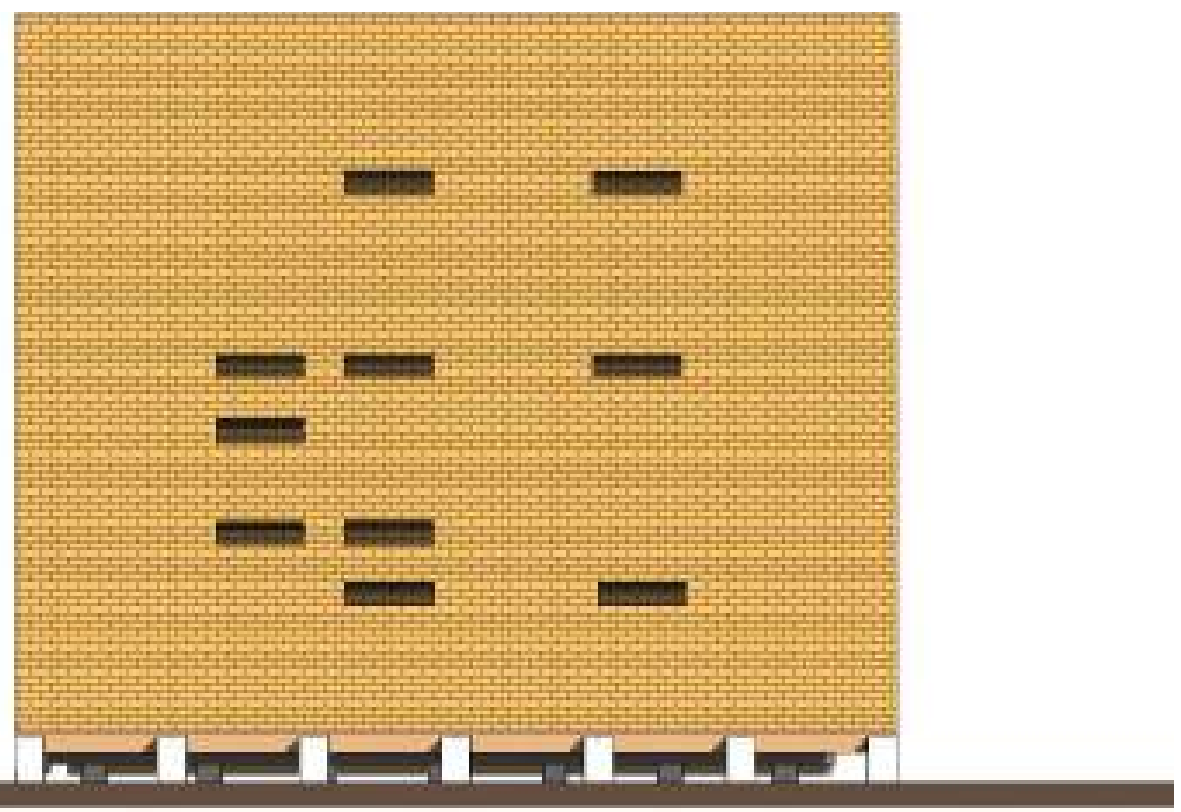

Long Section 1:200

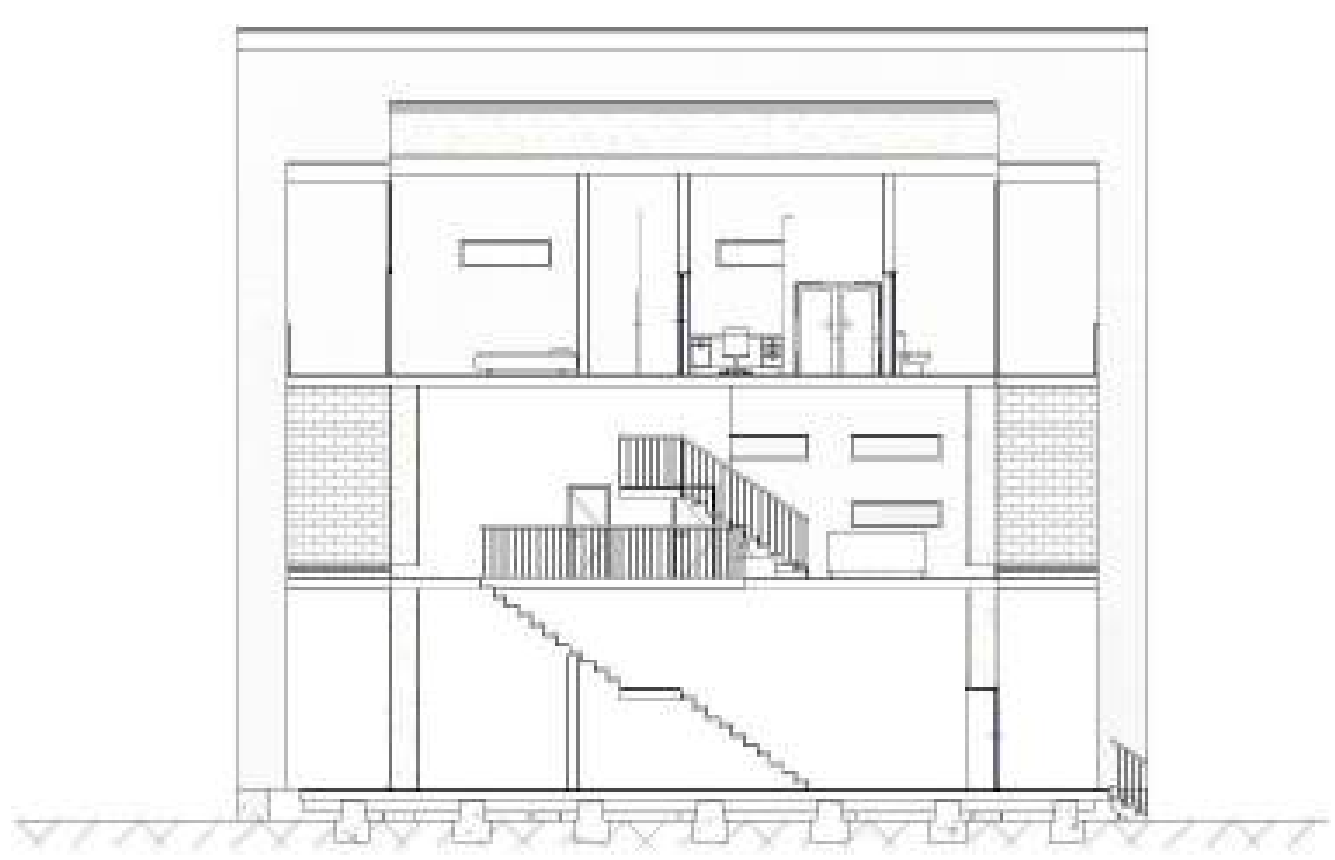

Cross Section 1:200
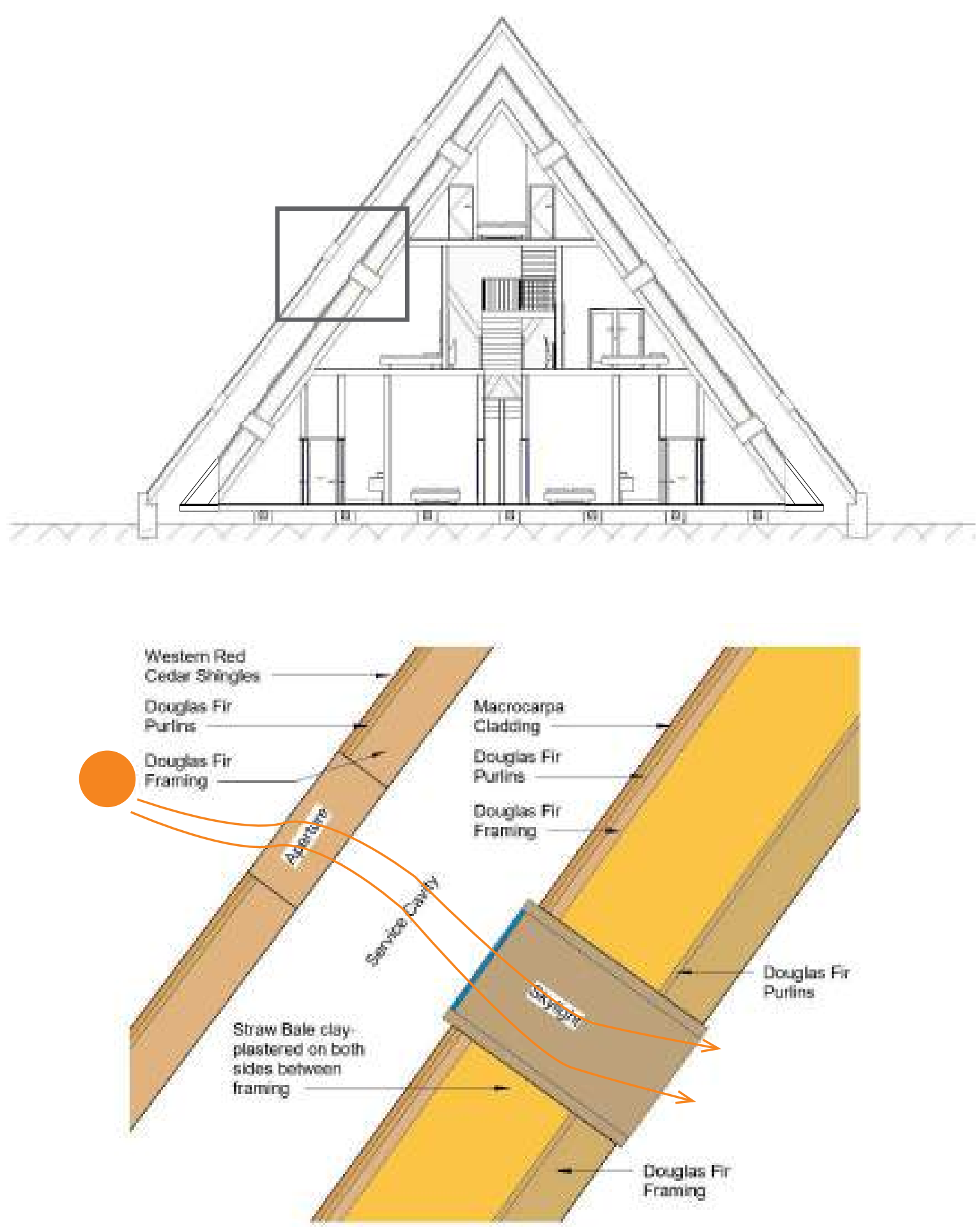

The exterior/roof is double skinned to visually emphasise as an architectural feature the importance of protecting biodegradable materials from moisture. The separation between the two exterior skins and their contrasting thicknesses creates a pleasant negative architectural detail as well as creating a practical service cavity for maintenance on the building's exterior. The offset between the inner and outer exterior layers also reduces the exposure of the windows to direct gravity-driven rain which minimises the chance of leaking around window joins. On the front and 


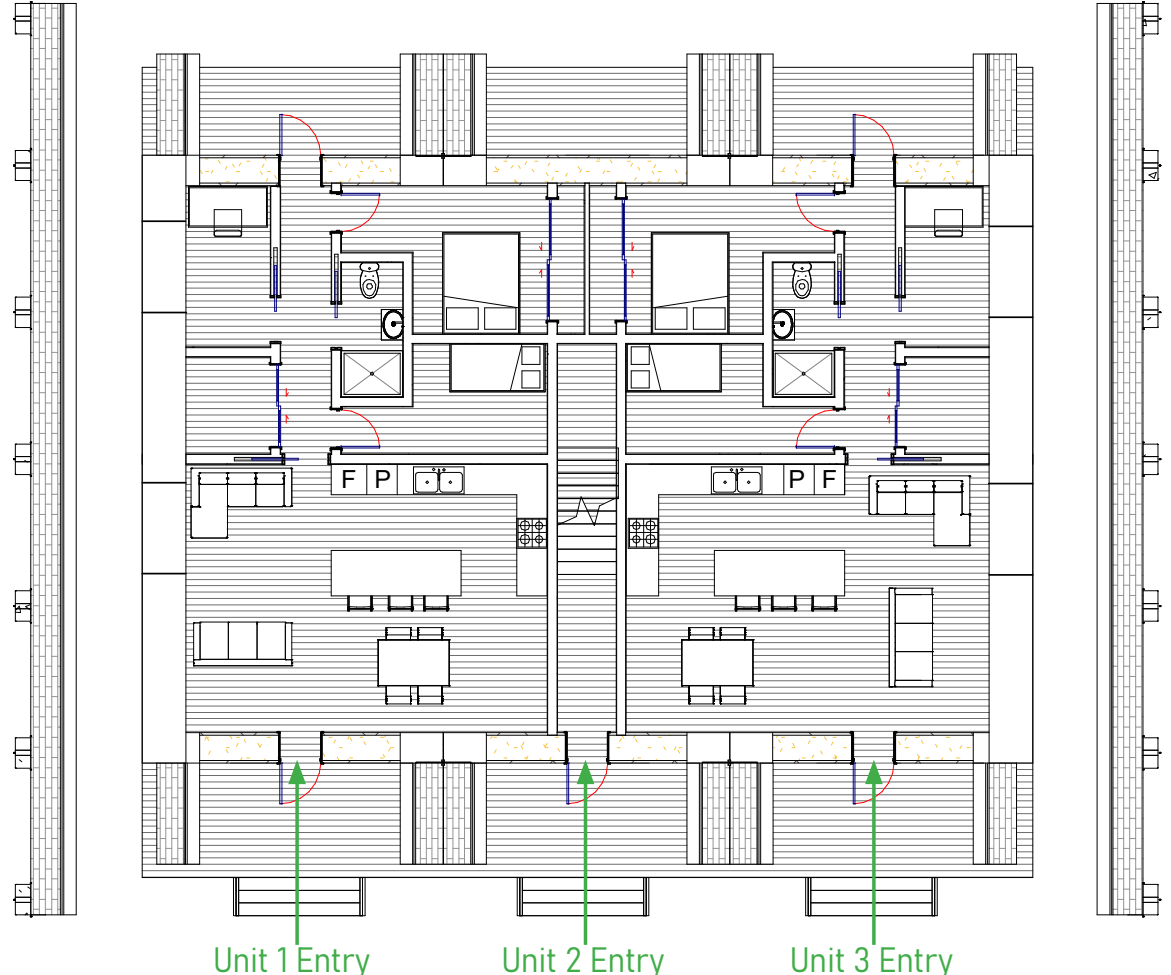

First Floor (Unit 3) 1:200

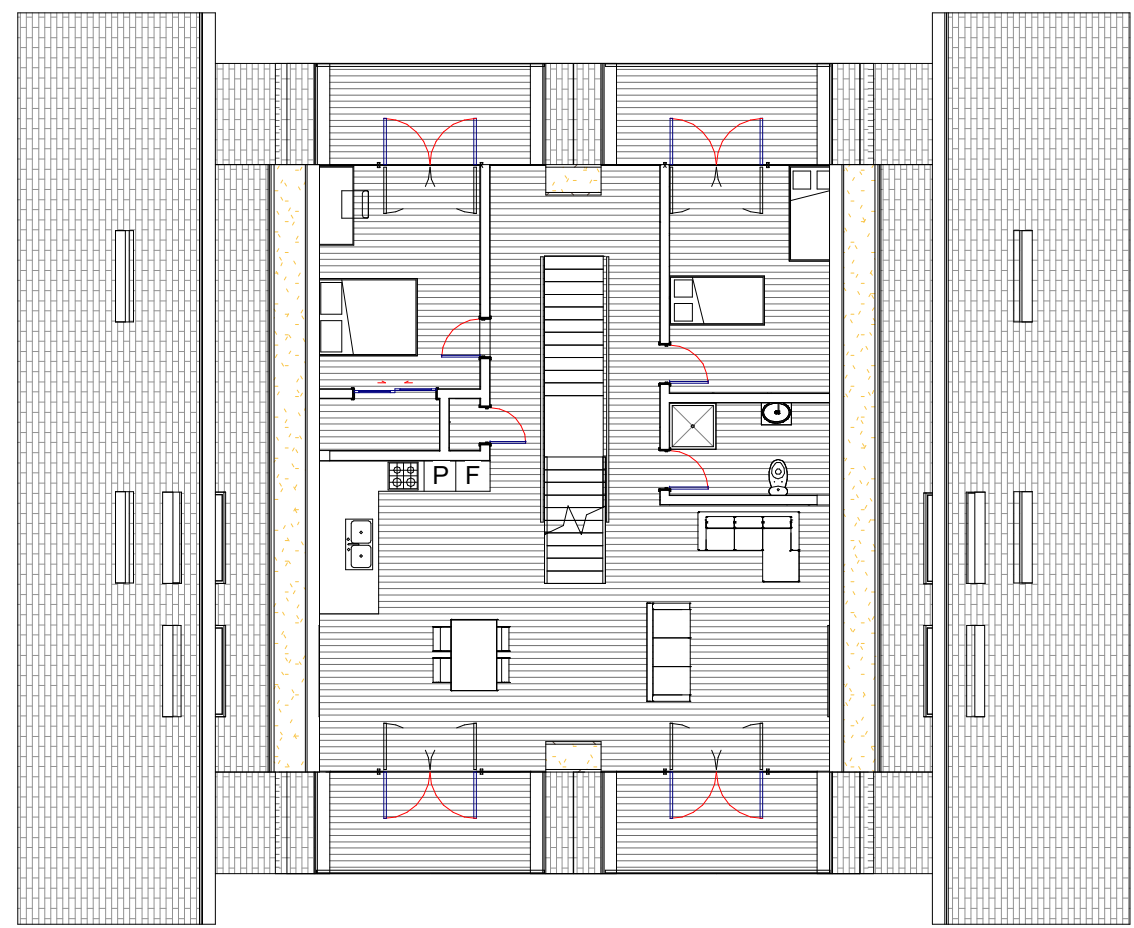

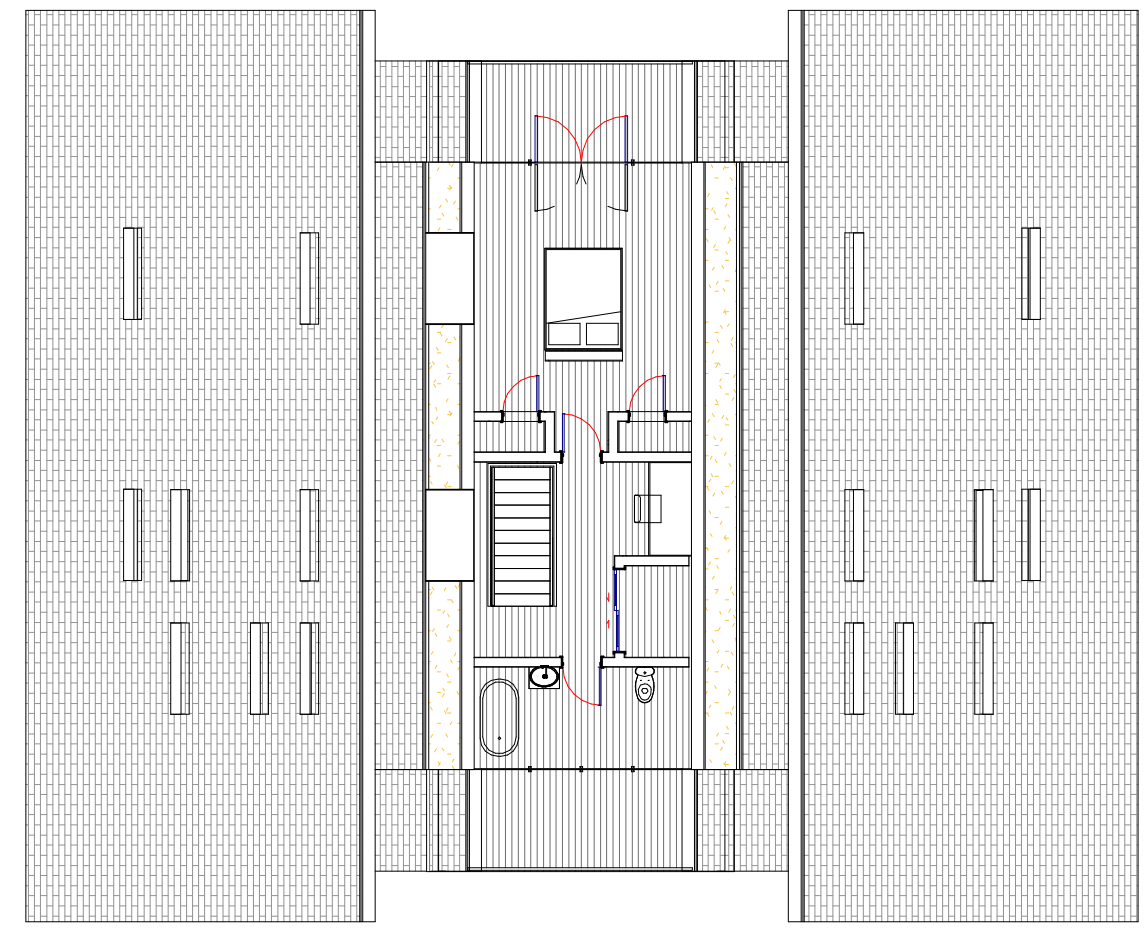

The design contains 3 isolated household units. Two units are on the ground floor each with 2 bedrooms and bathroom. The third unit occupies both the first and second floors and has 3 bedrooms and 2 bathrooms.

\section{Concept Reflection}

It is firstly noted that the slanted exterior walls would be a challenge to construct out of prefabricated panels as would the triangular wall profiles on the front and rear facades. In addition, despite the formal simplicity of the A-frame, the slanted walls reduce the amount of
habitable and useable space within the form. The width of the A-frame at the bottom also means that there is a reduction in opportunity for natural light penetration into the centre of the ground floor resulting in bedrooms with no windows. 


\subsection{Concept 2}

\section{Precedent Review}

\section{Figure 61}

BaleHaus, Bath, England, UK

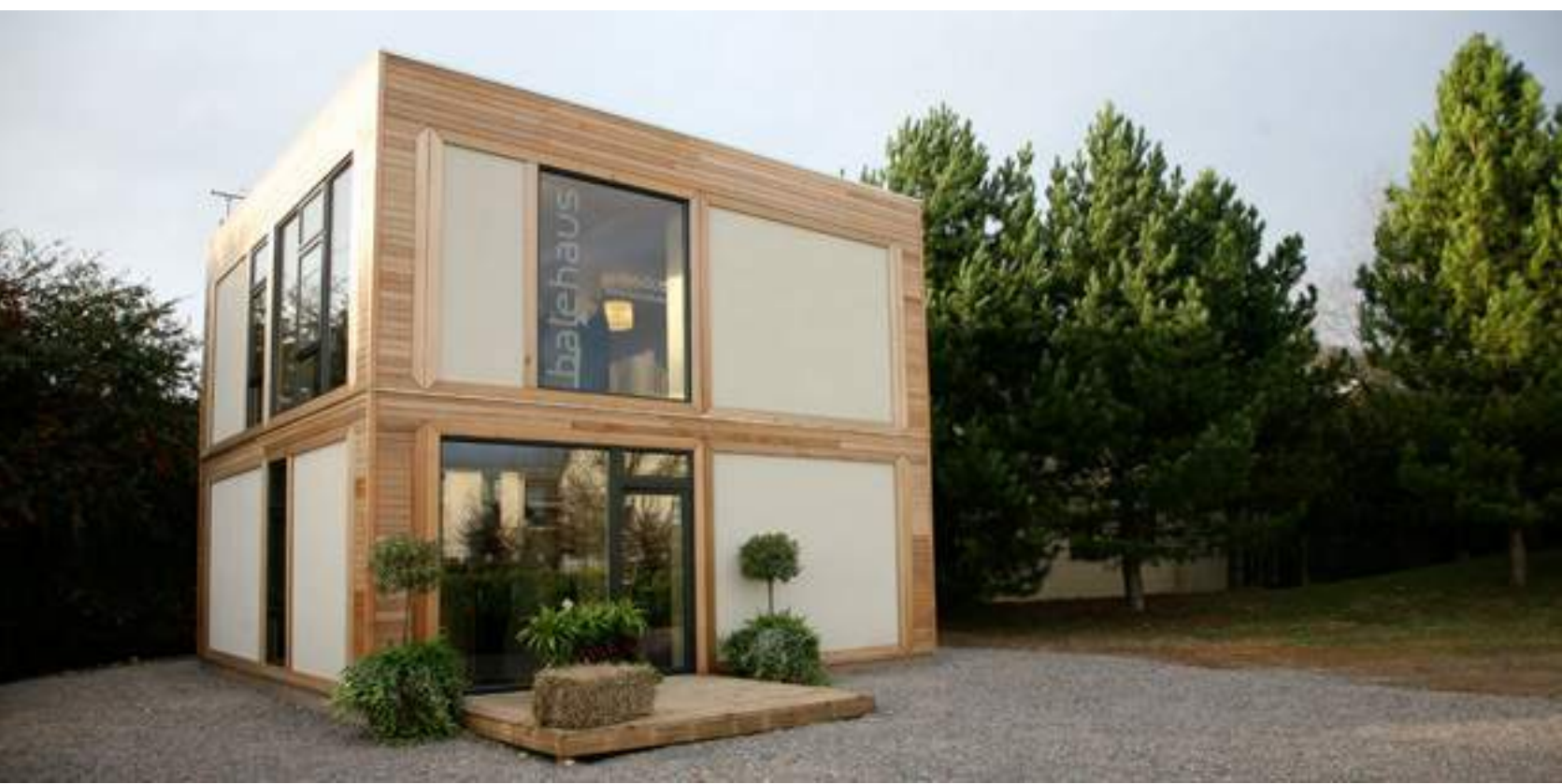

Note. Constructed with ModCell prefabricated straw bale wall panels. Retrieved from Modcell (https://www.modcell.com/ ews/balehaus-withstands-hurricanes/) on 18 April 2020.

\section{Figure 62}

Woodcube, Designed by architekturagentur Hamburg, Germany, 2013

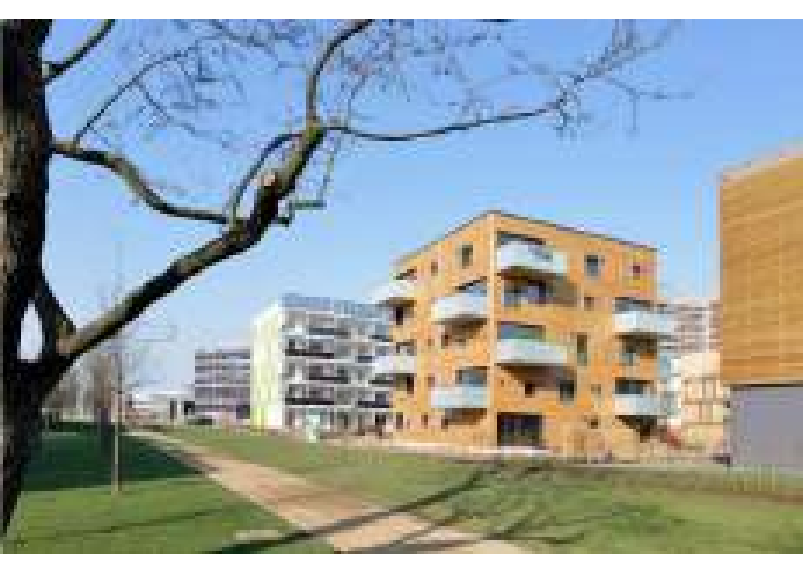

Photographs by Martin Kunze. Retrieved from ArchDaily (https://www.archdaily.com/421676/woodcubearchitekturagentur) on 4 June 2020

(figure 61) are constructed out of prefabricated panels. The Woodcube uses an entirely timber prefabricated pane and the Balehaus uses a straw bate insulated panel Both designs make use of a cuboid form which is easy to construct out of prefabricated panels. However, both designs lack a steep roof with large overhangs which the proposed design will require. In addition, a cuboid form at the scale of the Woodcube results in a similar lack of natural light into the centre of the plan as was the case in concept 1 . The proposed design for concept 2 , therefore th
Design Proposal

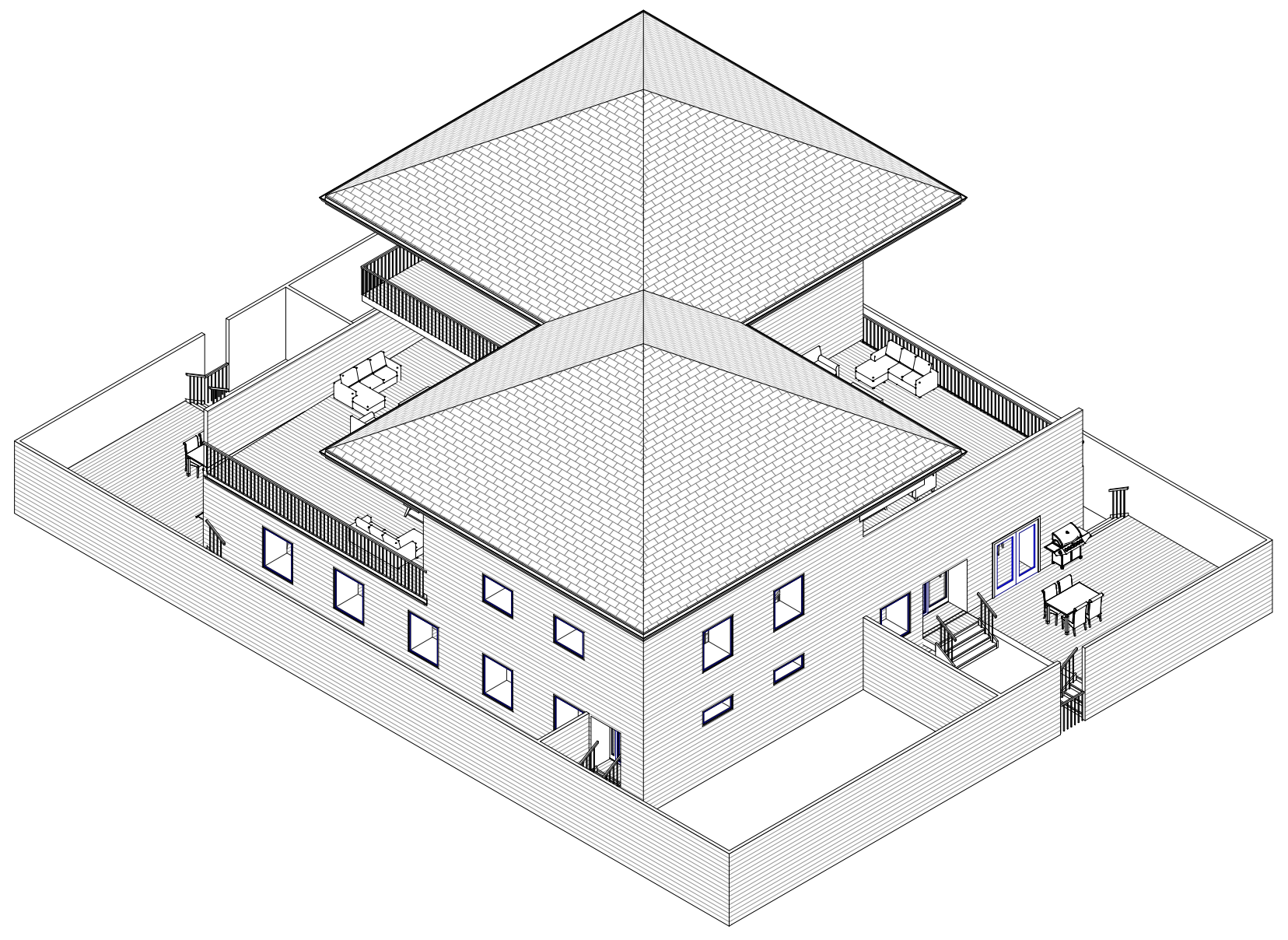
cuboid form used by the precedents but with volumetric subtractions to increase opportunities for natural light penetration into the core of the building and an added steep hipped roof with large overhangs. A hipped roof is

from the prefabricated panels. Due to the increased exposed wall area compared to concept one, balconies are used in places to shield the exterior walls from rain. The vertical walls of this concept also mean that the deepset windows in the exterior walls provide opportunities for chosen for simplicity as it requires no angled wall profiles 


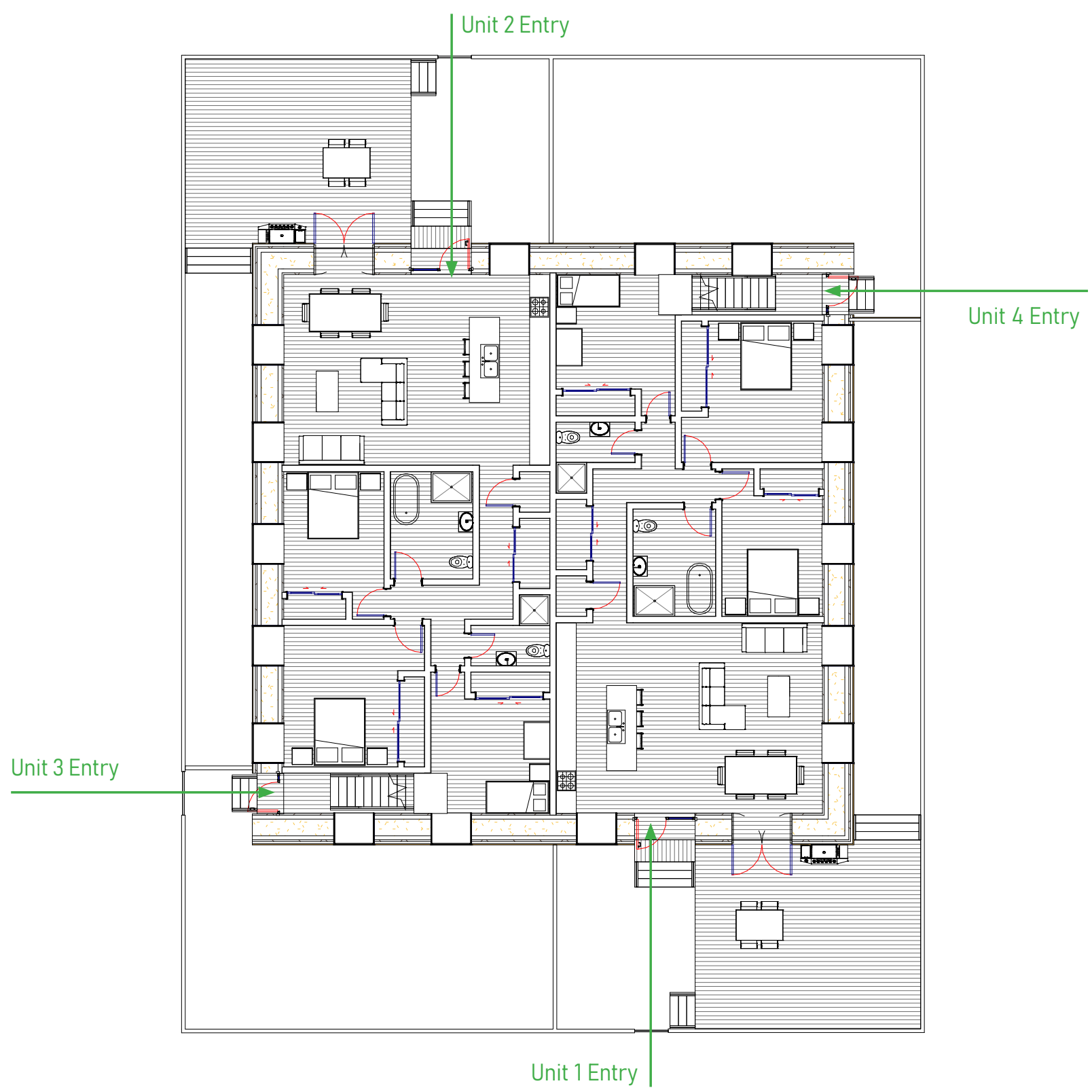

This concept contains 4 isolated accommodation units of identical volume. Units 1 and 2 are on the ground floor each with their own private outdoor deck/garden space.
Units 3 and 4 are spread over 2 storeys and are stacked above units 1 and 2. Units 3 and 4 have their own private units has lis own private ground-level access. The entries into the units are spread over the 4 facades for privacy.

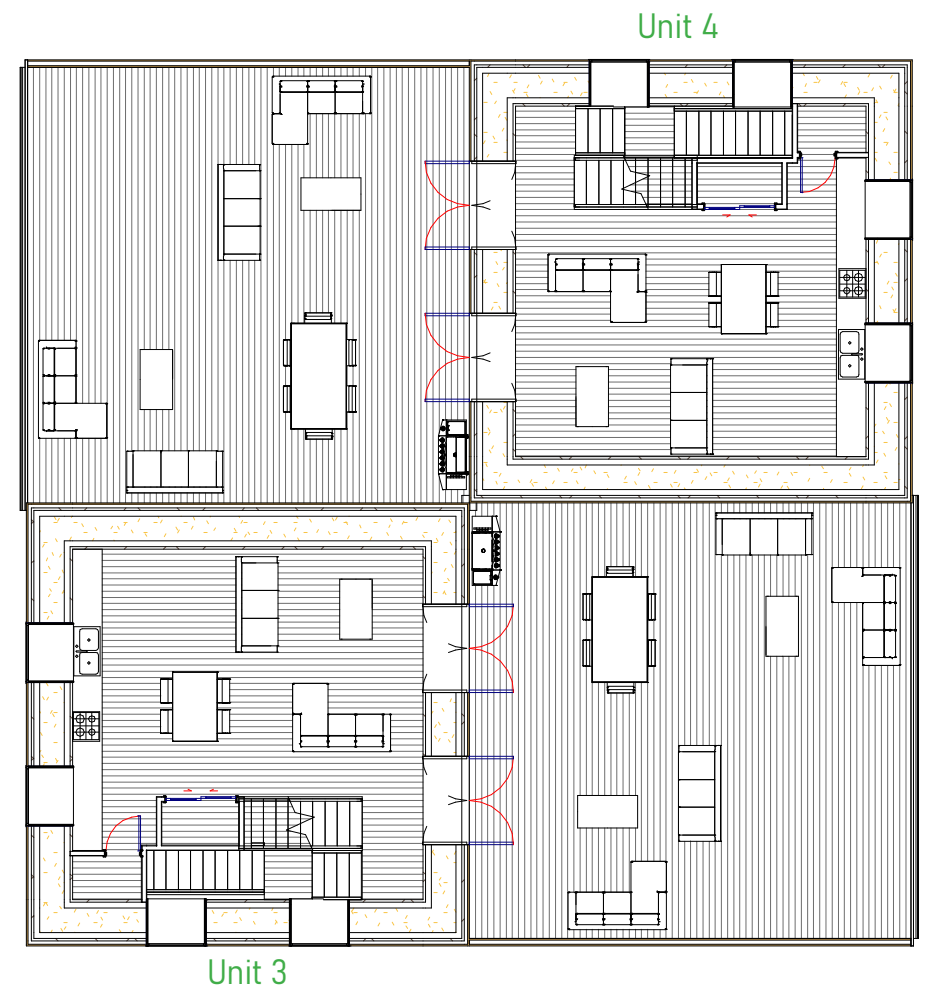

Second Floor Plan (1:200)

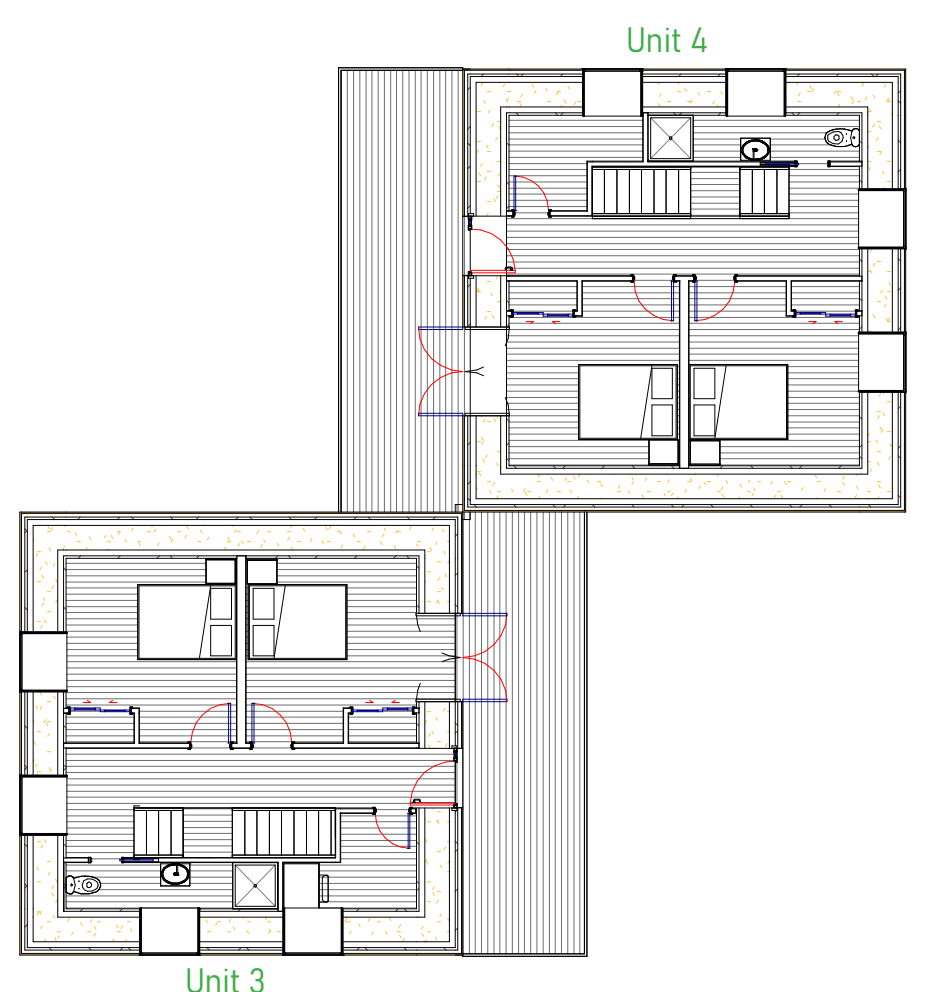




\section{Elevations (1:500)}
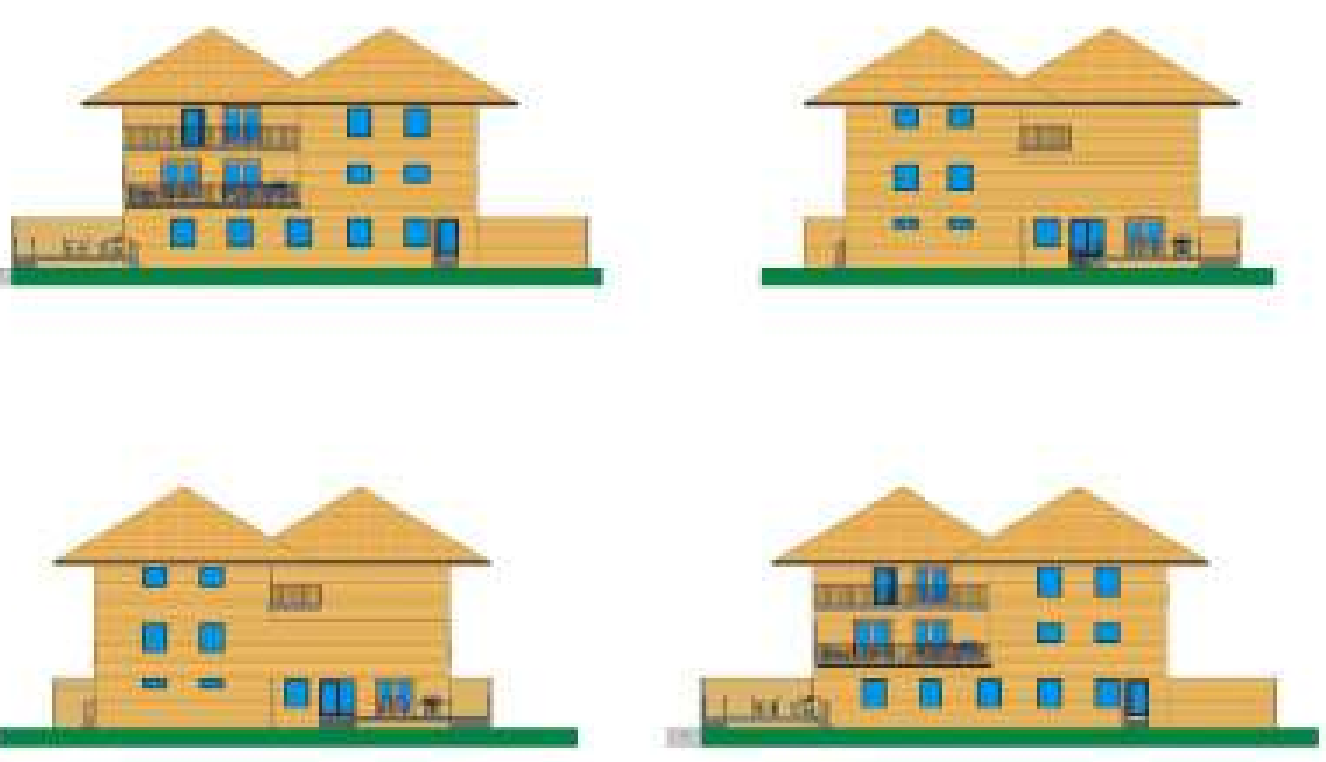

\section{Design Review}

Whilst subtracting volumes from the cuboid form has allowed more natural light into the interior of this concept it has created more exterior junctions where there are higher chances of leaks occurring In addition, the firstfloor balconies act as a flat roof over the ground floor and

are not a wise design strategy for water tightness. There are also instances on the first floor where required to go through a straw insulated exterior wall which is not ideal.

\subsection{Concept 3}

Precedent Review

Figure 63

Chalet in Switzerland, by Charles Pictet, 2008
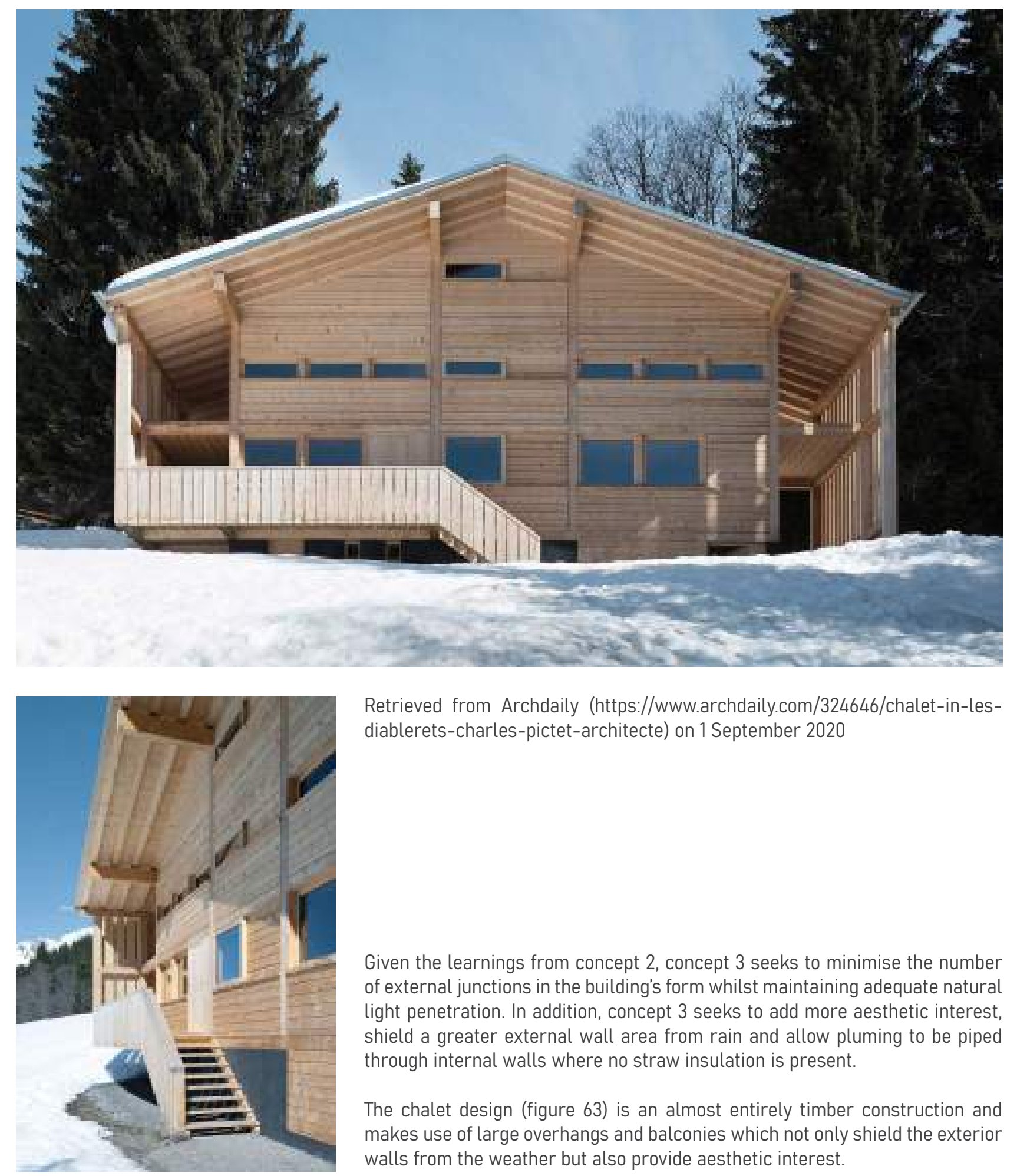

Retrieved from Archdaily (https://wwwarchdailycom/324646/chalet-in-lesdiablerets-charles-pictet-architecte) on 1 September 2020

Given the learnings from concept 2, concept 3 seeks to minimise the number of external junctions in the building's form whilst maintaining adequate natur light penetration. In addition, concept 3 seeks to add more aesthetic interest, shield a greater external wall area from rain and allow pluming to be piped through internal walls where no straw insulation is present.

The chalet design (figure 63) is an almost entirely timber construction and makes use of large overhangs and balconies which not only shield the exterior walls from the weather but also provide aesthetic interest. 


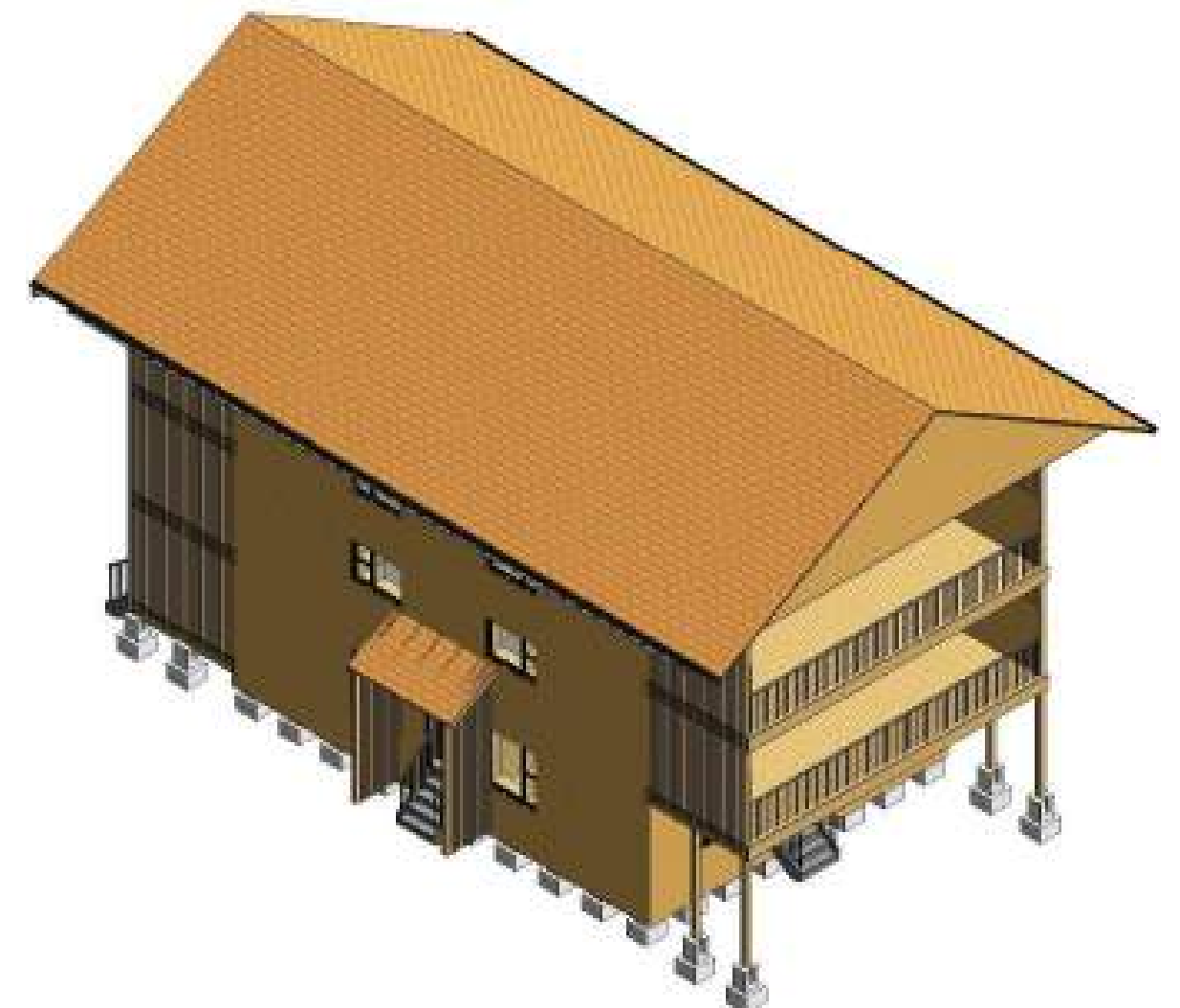

The proposed design for concept 3 is smaller than concept 2 allowing for a simpler form that receives sufficient natural light into the interior. The design also incorporates a gable roof with large overhangs and balconies similar

interest compared to the hip roof of the previous concept. In addition, the smaller form allows the roof and balconies to shield more external wall area than concept 2. The need to be piped through external walls.

\section{Elevations 1:200}
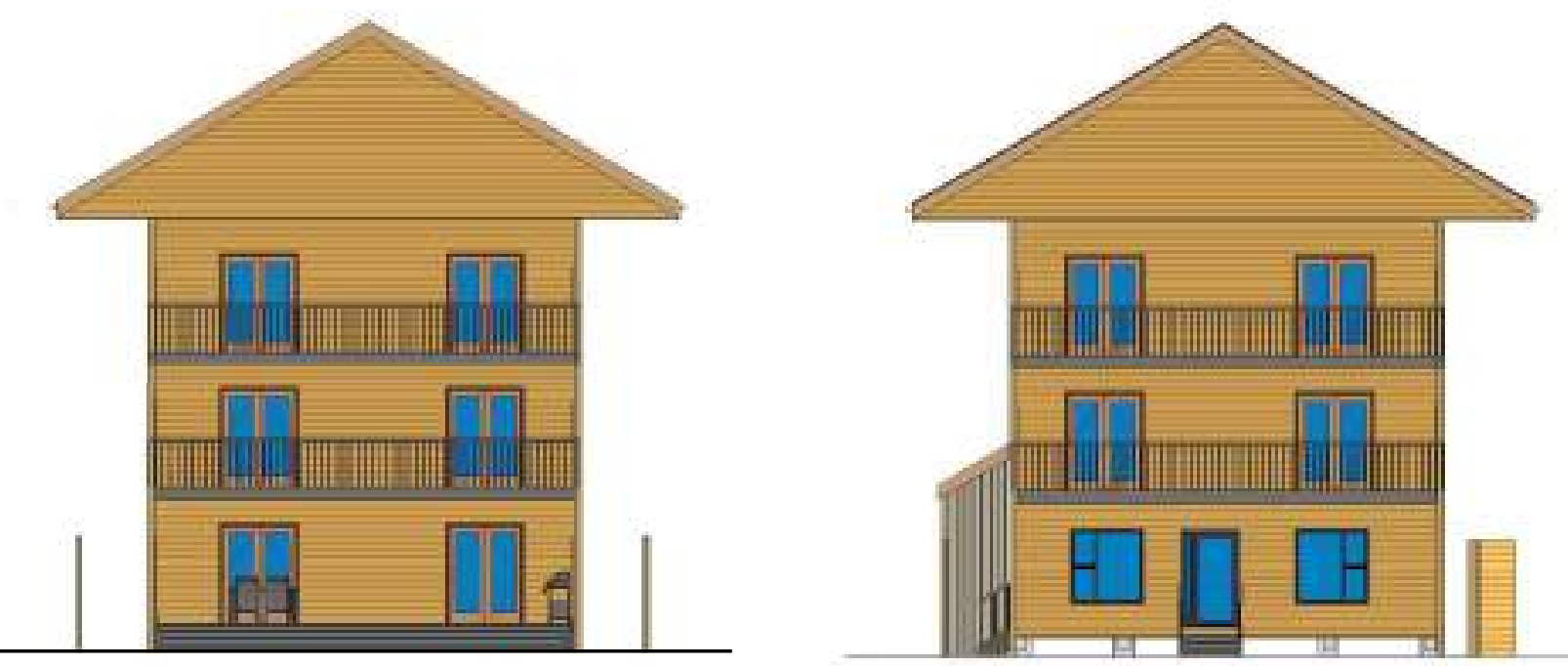
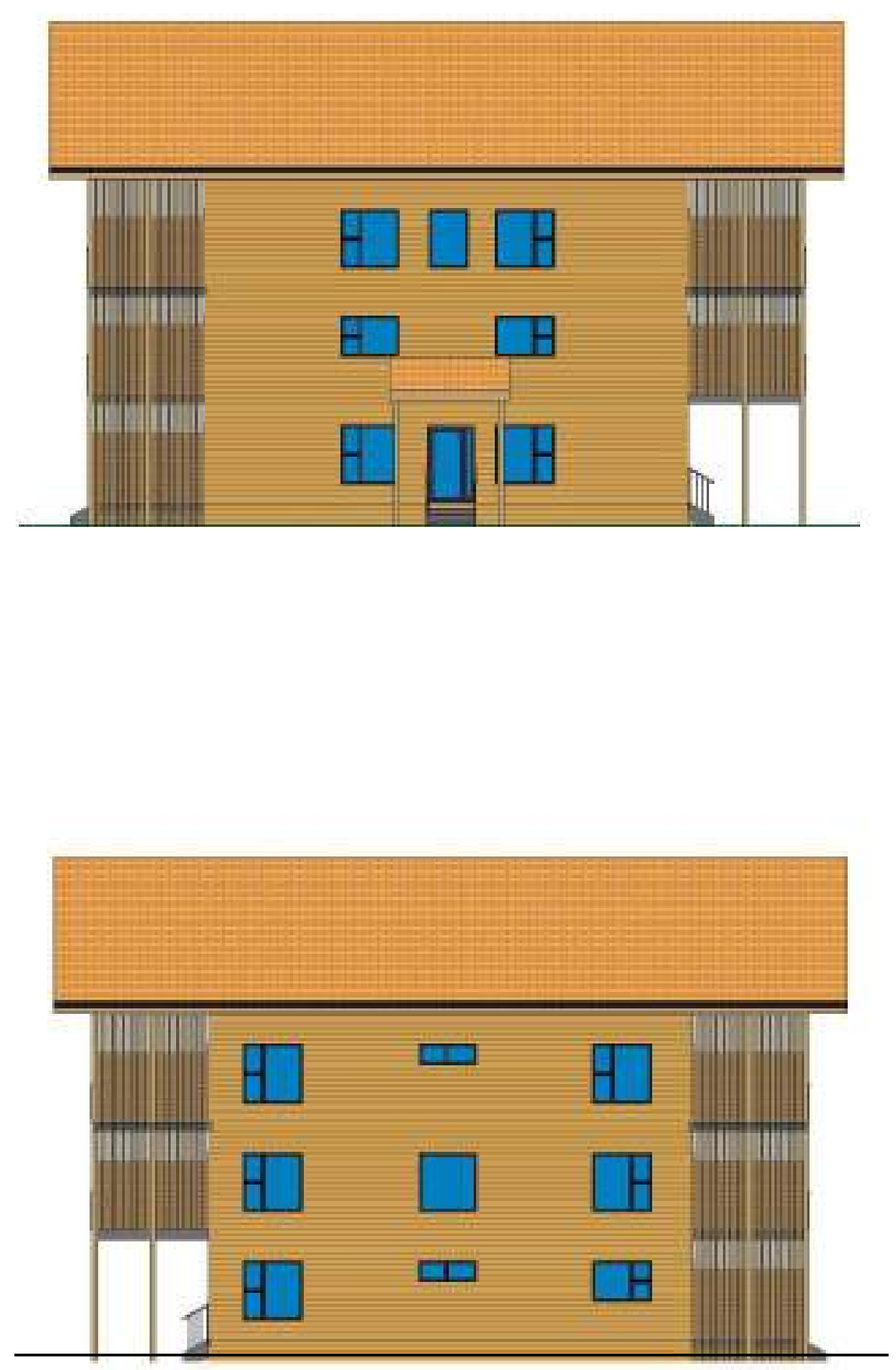


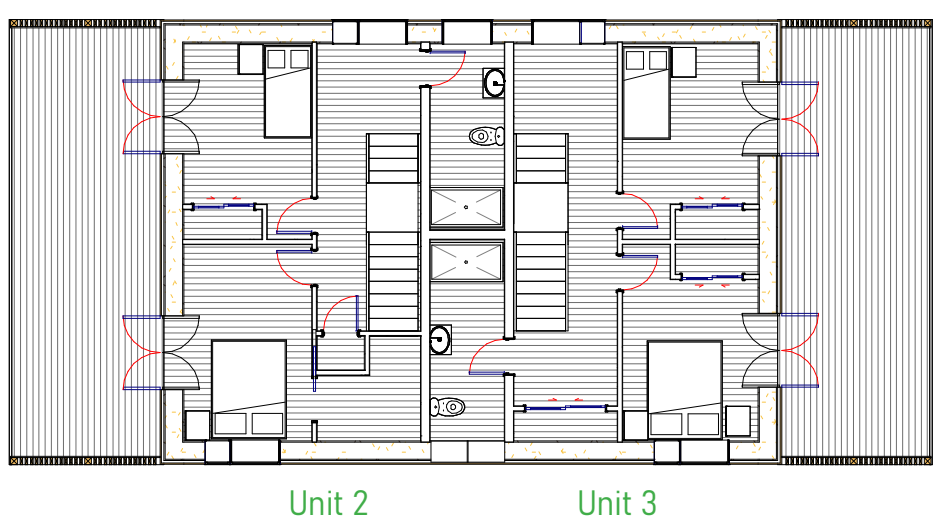

First Floor Plan 1:200

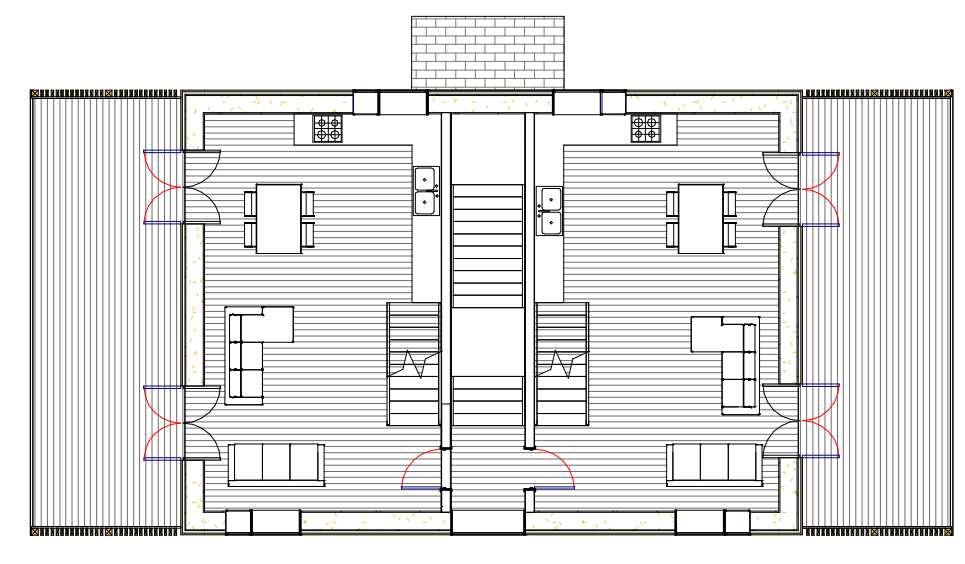

Unit 2

Unit 3

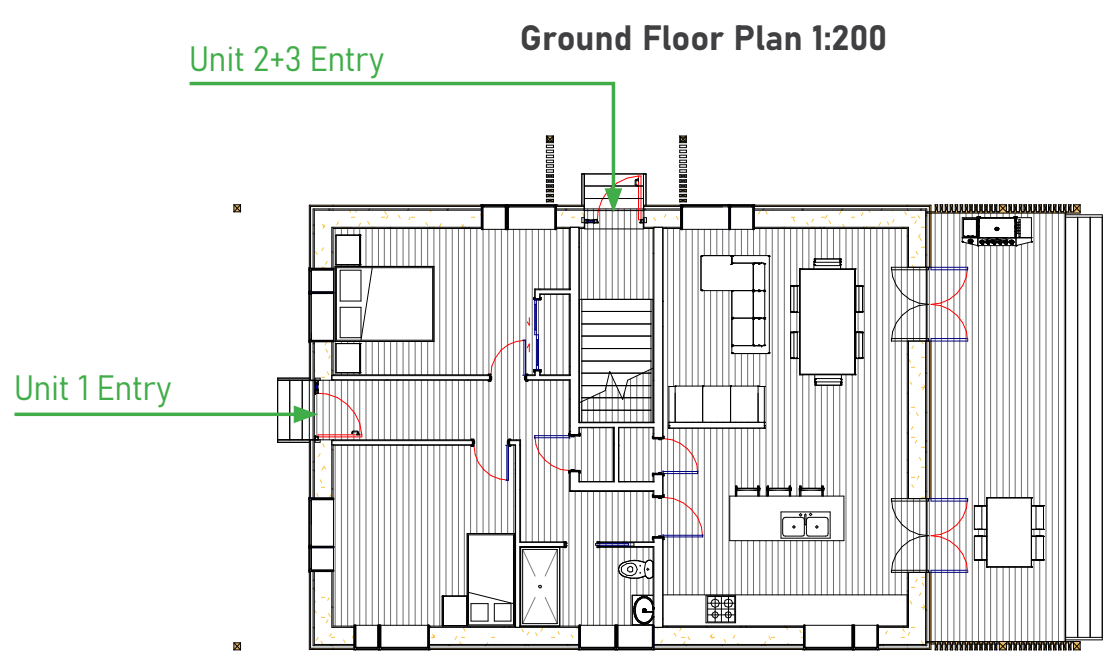

The design has 3 isolated units each with two bedrooms and one bathroom. Unit 1 is on the ground floor and has both two storeys and are above unit 1. A shared stairway in the centre of the building is used to access units 2 and 3 .

\subsection{Review of Concept Designs}

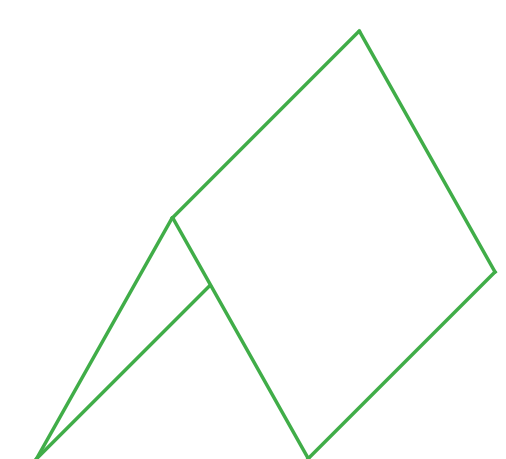

Concept 1

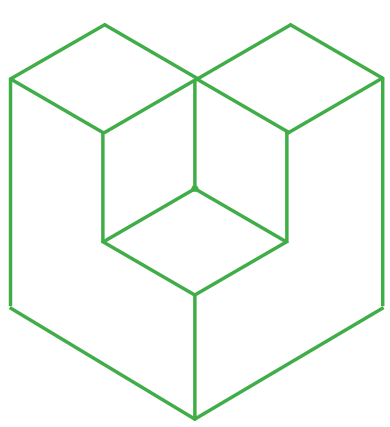

Concept 2

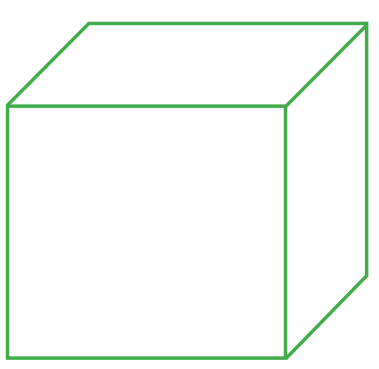

Concept 3

\begin{tabular}{|l|l|l|l|l|}
\hline $\begin{array}{l}\text { Formal Simplicity (minimising } \\
\text { complex junctions where leaks } \\
\text { are more likely is desirable for } \\
\text { biodegradable materials) }\end{array}$ & \multicolumn{2}{l|}{ Dwelling Density } & \\
\hline Concept 1 & $\begin{array}{l}0.3 \text { exterior junctions/ } \\
\text { dwelling }\end{array}$ & Concept 3 & 294 bedrooms/hectare & 3 points \\
\hline Concept 3 & $\begin{array}{l}2.6 \text { exterior junctions/ } \\
\text { dwelling }\end{array}$ & Concept 2 & 192 bedrooms/hectare & 2 points \\
\hline Concept 2 & $\begin{array}{l}6.25 \text { exterior junctions/ } \\
\text { dwelling }\end{array}$ & Concept 1 & 148 bedrooms/hectare & 1 point \\
\hline
\end{tabular}

\begin{tabular}{|l|l|}
\hline $\begin{array}{l}\text { Most suitable concept } \\
\text { design }\end{array}$ & Total Points \\
\hline Concept 3 & 5 points \\
\hline Concept 1 & 4 points \\
\hline Concept 2 & 3 points \\
\hline
\end{tabular}

Concept 3 is the result of an iterative design cycle attempting to find a building form that firstly supports the use of biode finadable building materials and secondly a suitable medium density housing design. In addition it aso ates the best in terms of formal simplicity and dwelling density. It may not have the simplest form out of the concepts, but it does have the greatest dwelling density Which is desirable. Concept 1 has the simplest form but other to concepts. complex form and had a dwelling det 2 had the most 


\section{Site Integration}

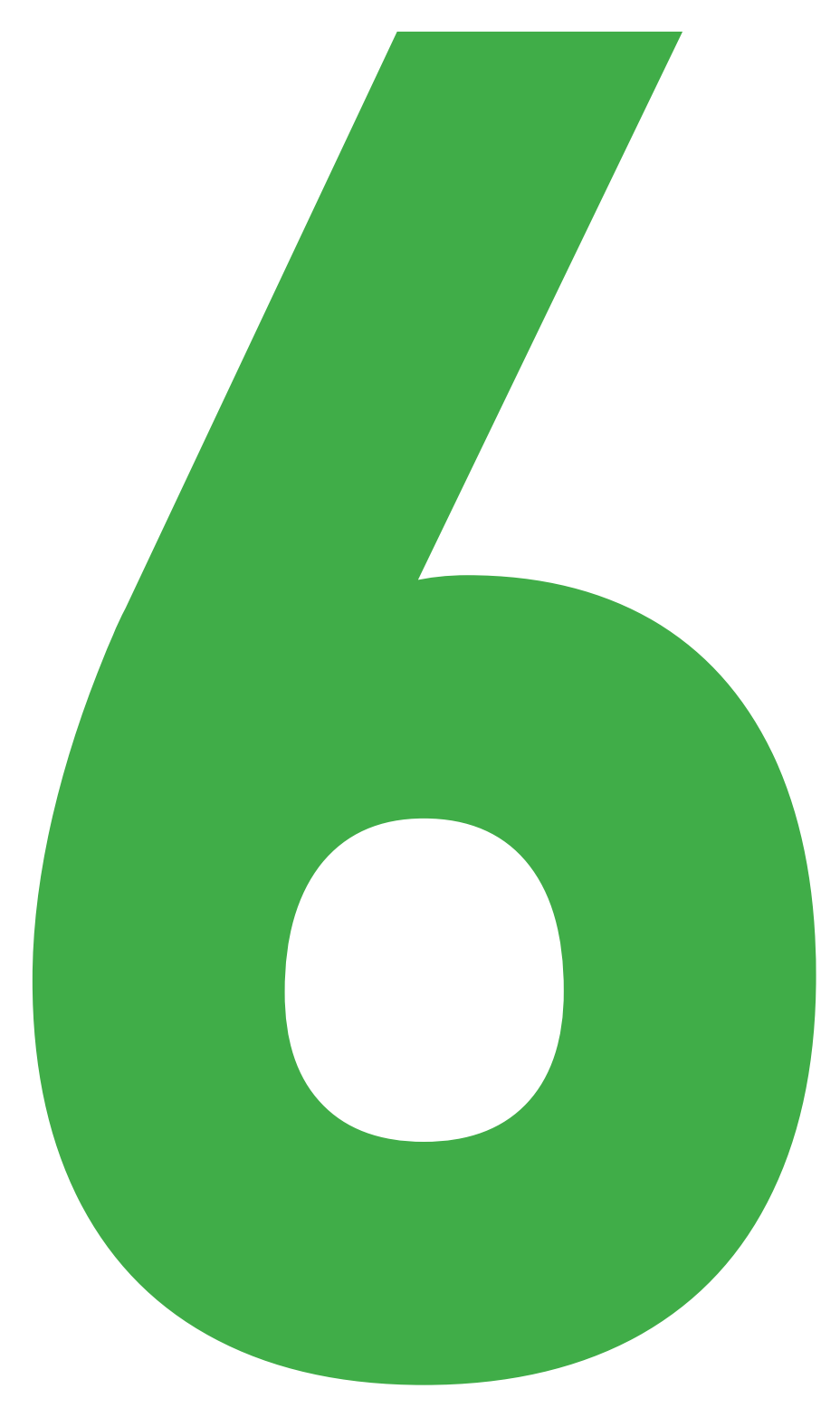

\section{Chapter Outline}

Although a sited is not a primary objective, no architectural design is ever produced in isolation to its site. Therefore, the design needs to be integrated with a site to architecturally test the bulding design. A sited design is also required to demonstrate the potentiat of applying biodegradable building materials to an urban ste at the scale of a medium density housing deverof architectural typology of medium density housing requires

careful consideration of site and inter-unit relationships. However, because a site development design does not contribute towards the thesis objectives it is not pursued beyond the point of architectural sufficiency. It is instead the building design which is used to pursue and assess the thesis objectives. A suitable site is selected befor inform the layout of the proposed site development.

\subsection{Selected Site}
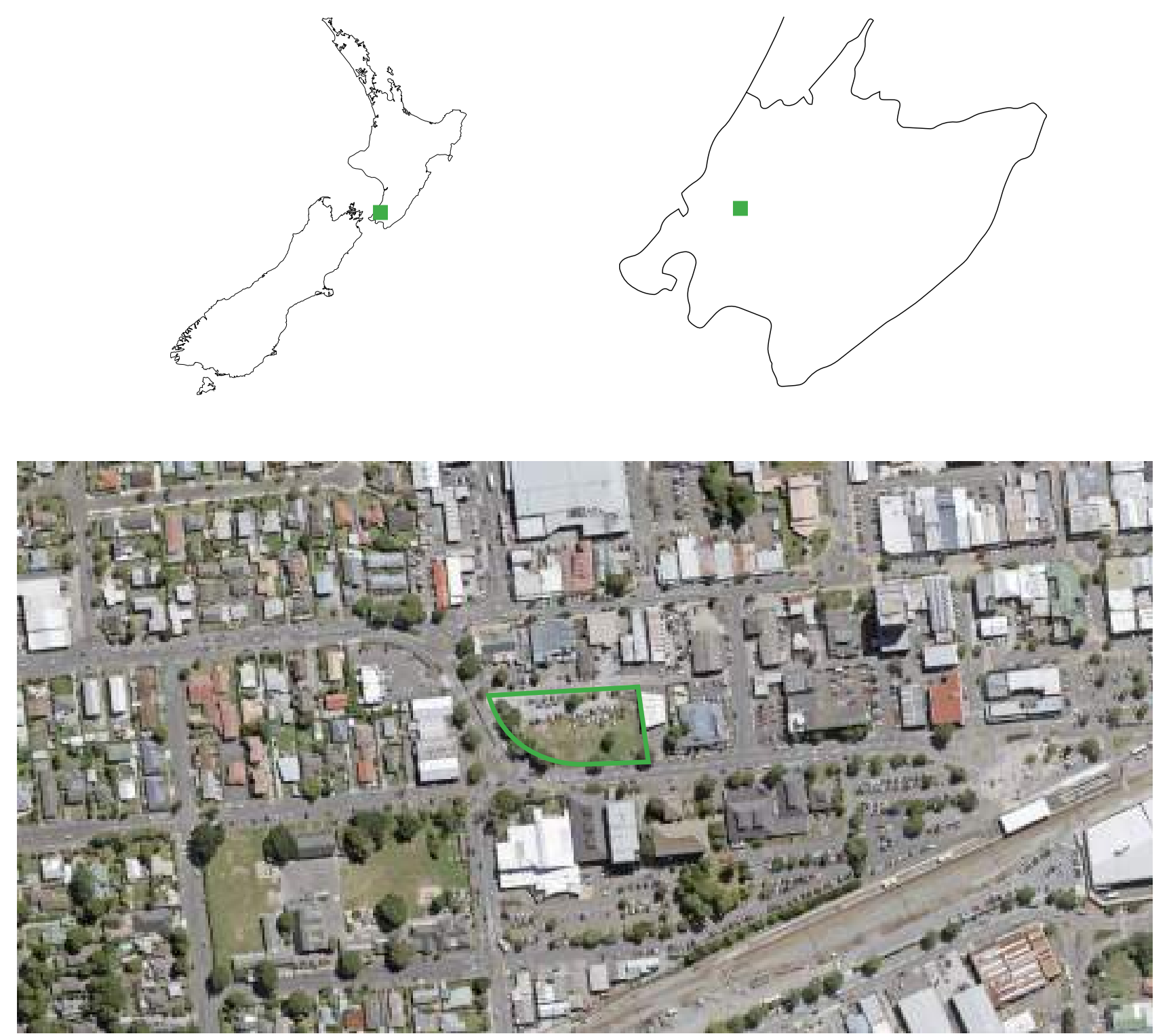

Location: Upper Hutt City

Size: approximately $98 \mathrm{~m} \times 51 \mathrm{~m}$

Area: $4262 \mathrm{~m}^{2}$ 


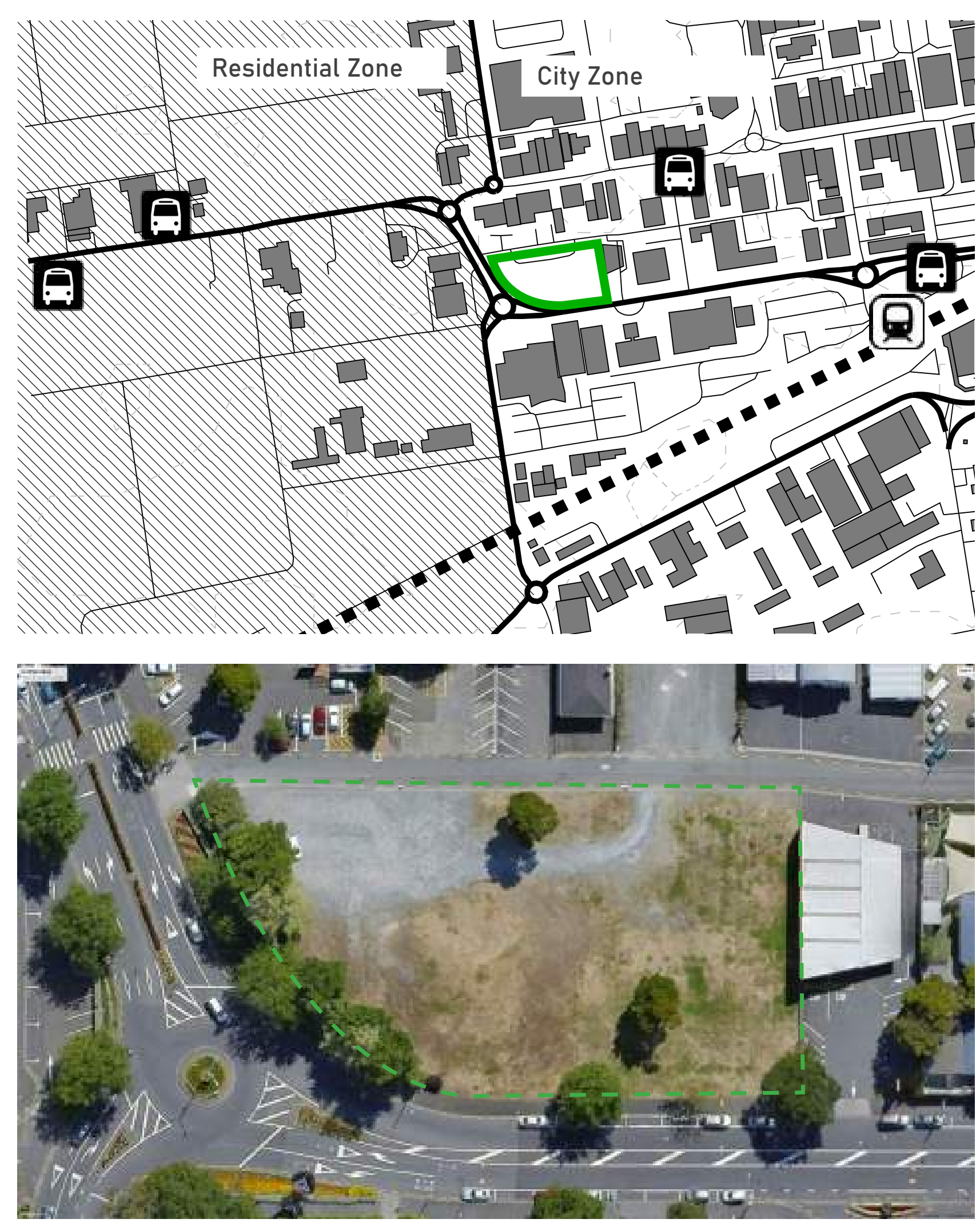

Site Selection Reasons:

1. Flat

2. Prime location for $\mathrm{MDH}$ on the boundary between residential and city zones

3. Green field site means the objective of zero-waste will not 4. Suffromised through demolition

Sufficient public transport nodes and amenities nearby

\subsection{Medium Density Housing Precedents}

Figure 64

Earthsong Eco-Neighbourhood, Waitakere, New Zealand

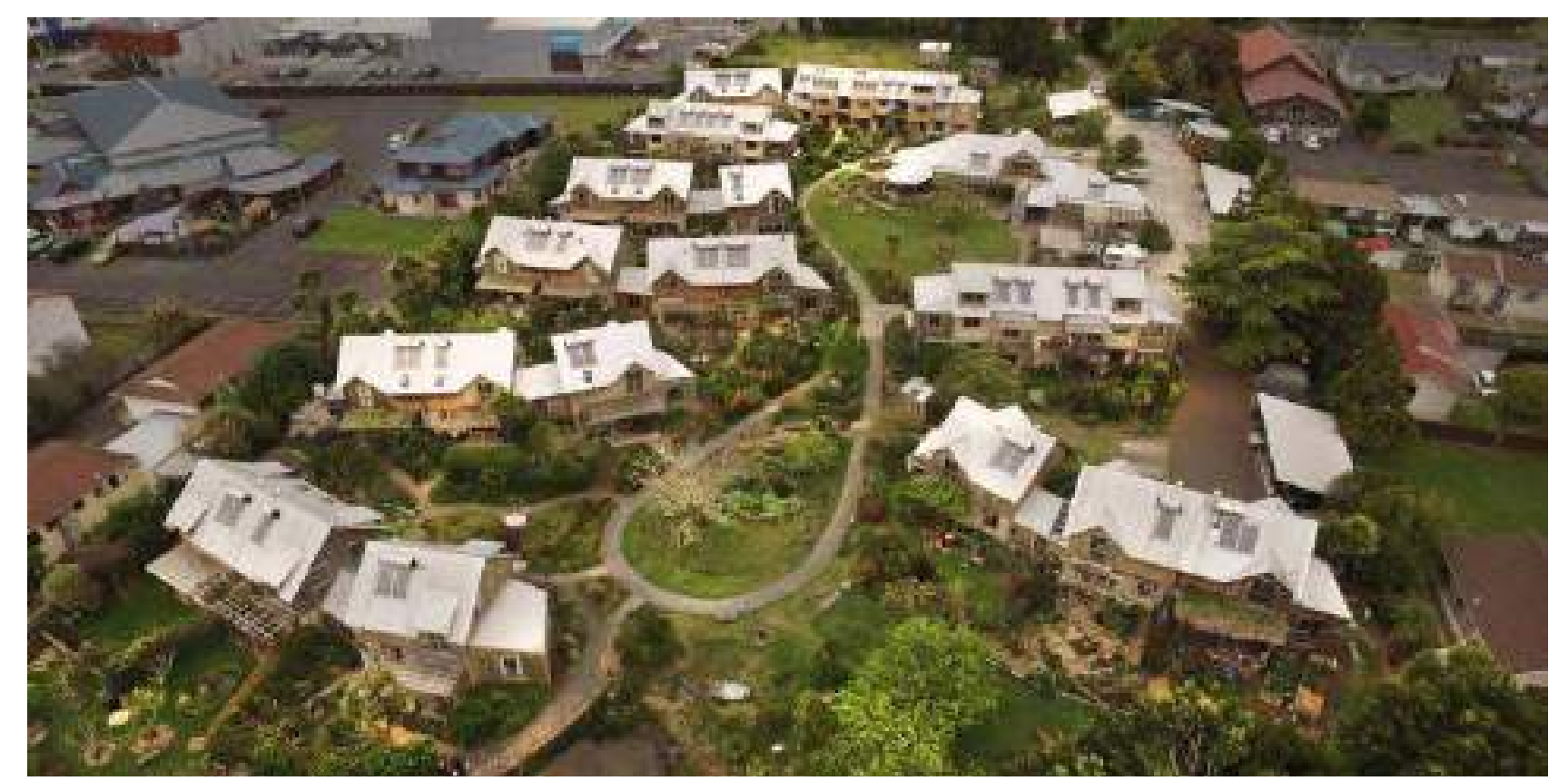

Retrieved from Cohousing New Zealand (https://cohousing.org.nz/communities/earthsong-eco-neighbour-hood) on 25 May 2020

Figure 65

Earthsong Site Plan, Waitakere, New Zealand

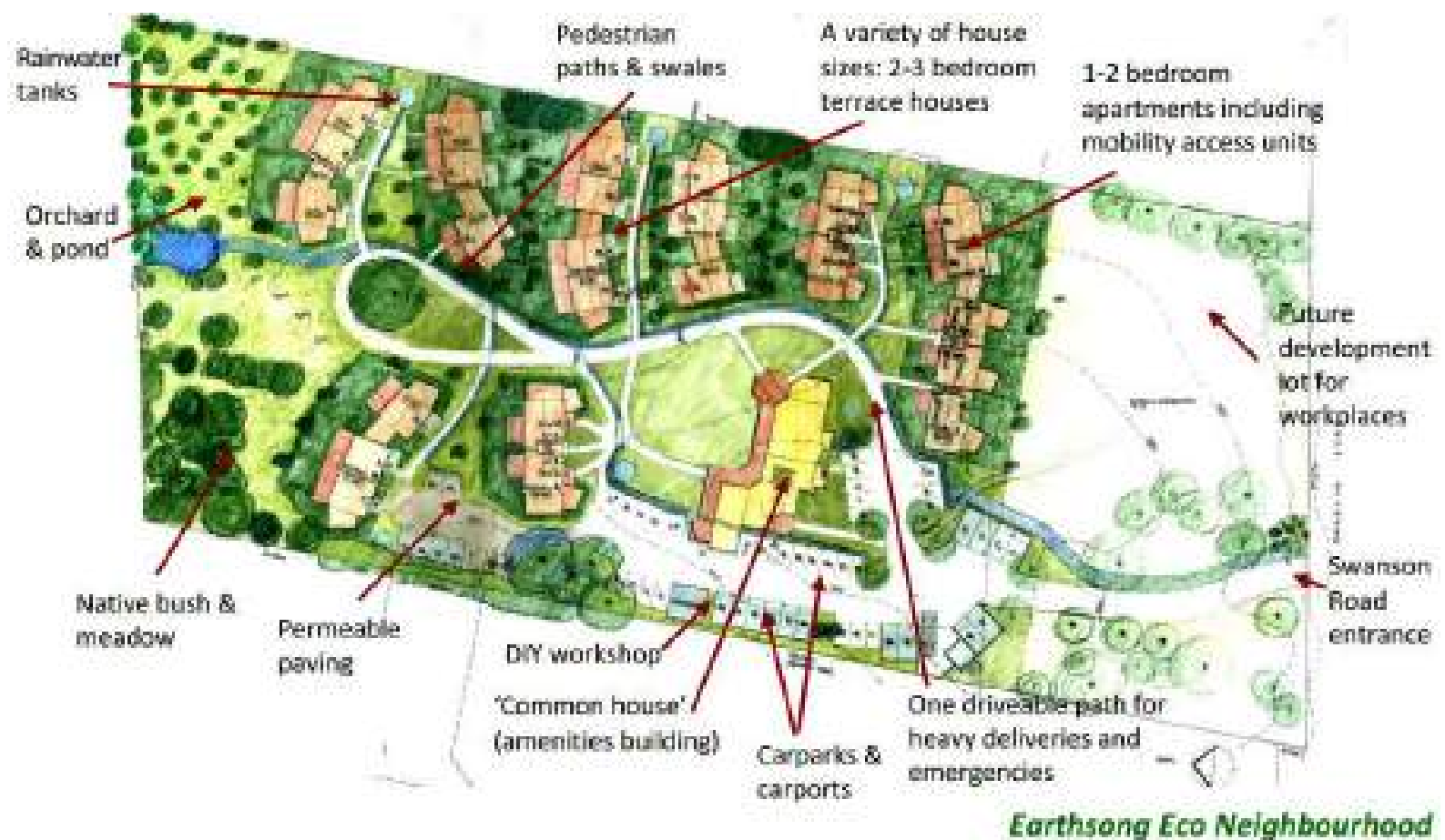

Retrieved from Pinterest (https://www.pinterest.nz/pin/66920744441849954/) on 25 May 2020 

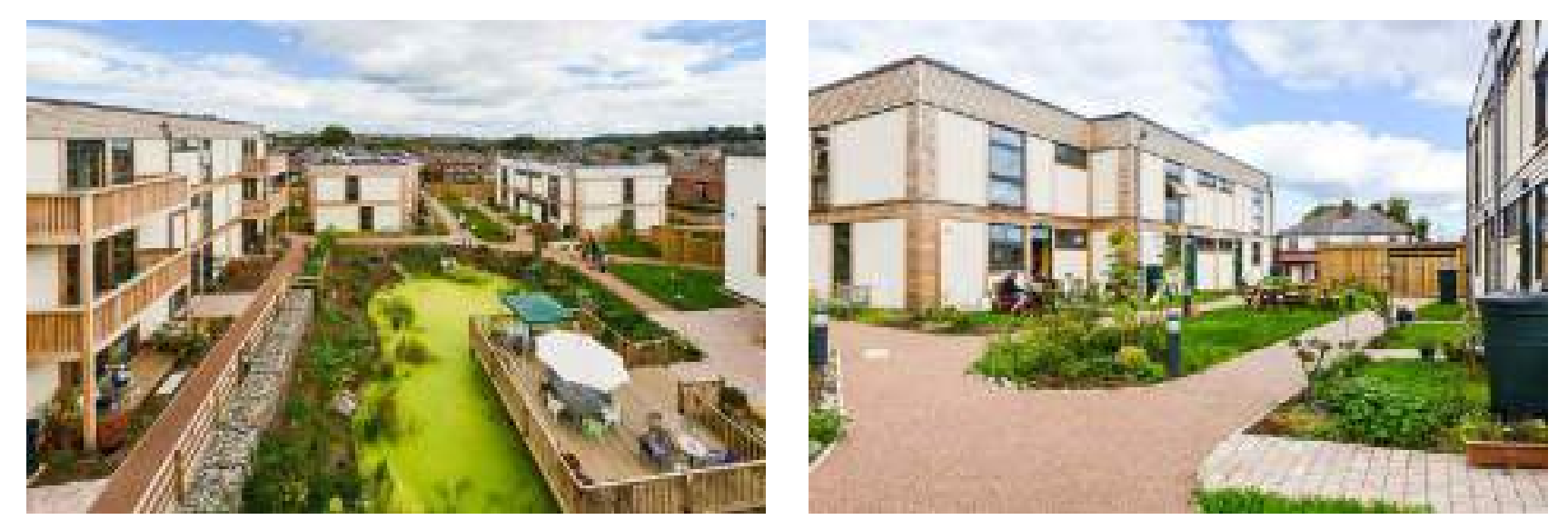

Retrieved from ModCell (https://www.modcell.com/projects/lilac-affordable-ecological-co-housing/) on 10 March 2020

Figure 67

LILAC Ariel Image

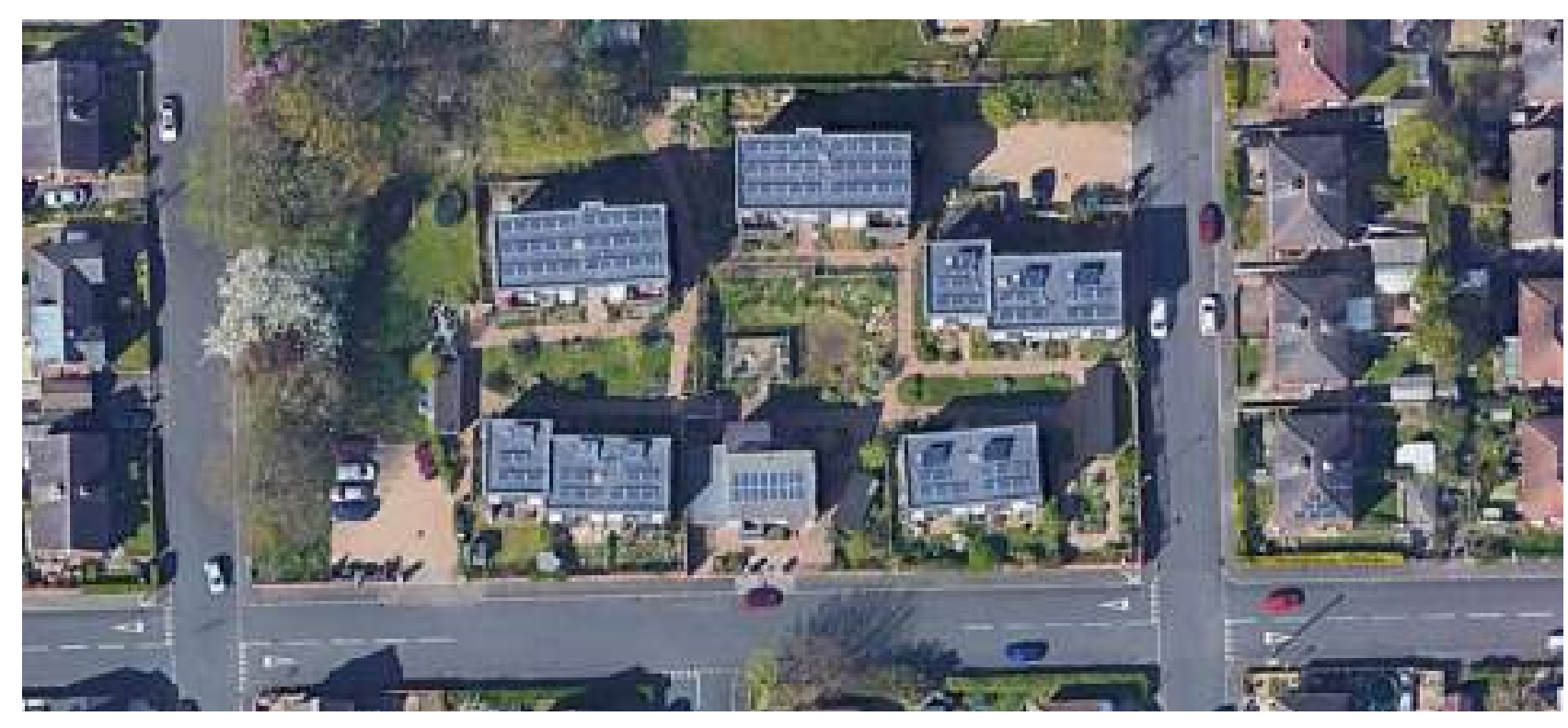

Retrieved from Google Images (https://goo.gl/maps/AfAmrAtmGGy7qe9c8) on 10 March 2020

Earthsong (figure 64,65) and LILAC (figure 66,67) are both medium density housing precedents that have a focus on environmental sustainability. Earthsong is in New Zealand and is constructed primarily out of untreated timber and

earth ULAC is in the UK and primarily constructed out of

from ModCell $₫$. Both developments offer a range of unit sizes and an abundance of green space. Both also have car parks located at the perimeter of the site reducing the need for paved areas within the complex and making the development more pedestrian-friendly.

\subsection{Site Development Proposal}

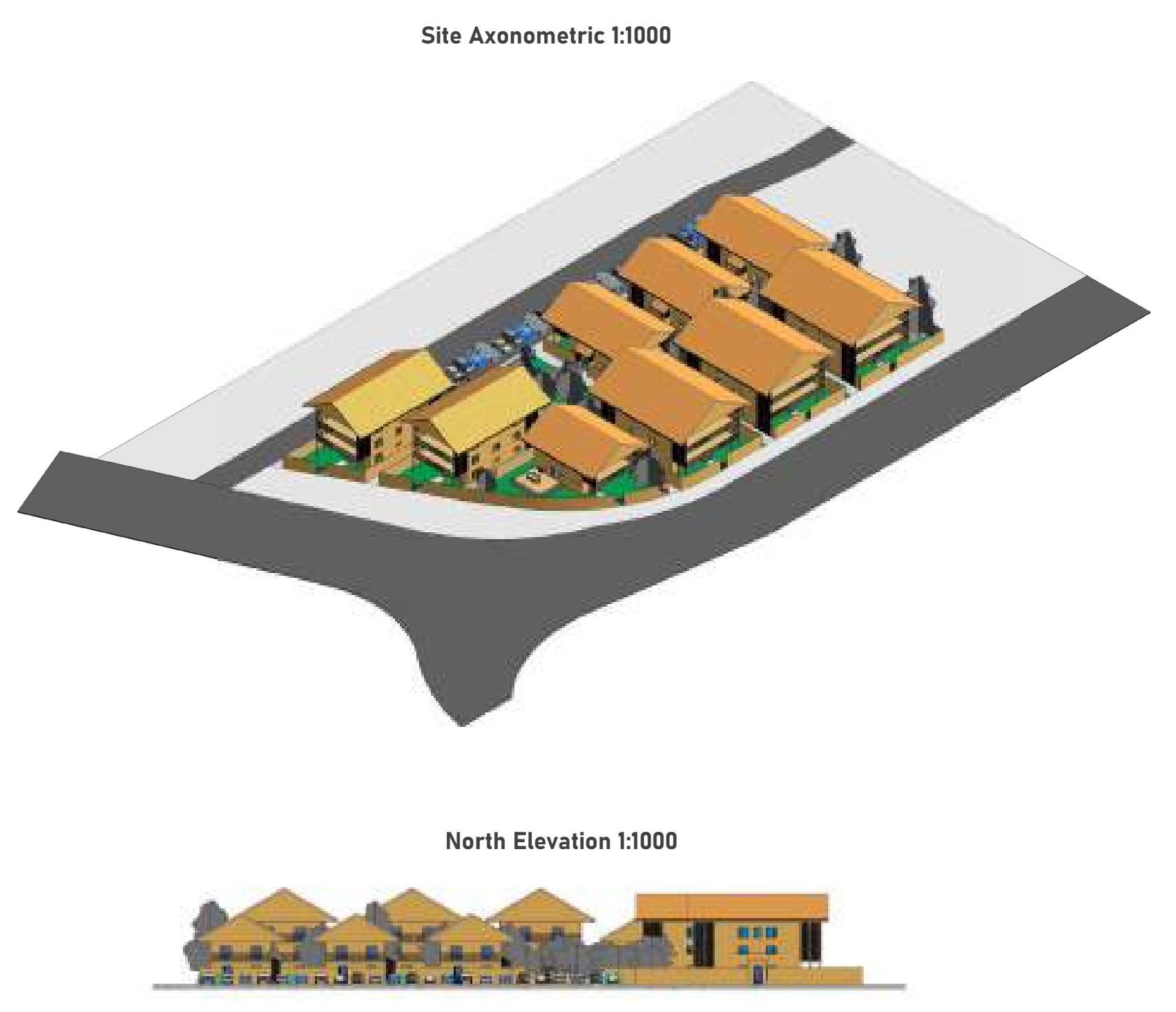

South Elevation 1:1000

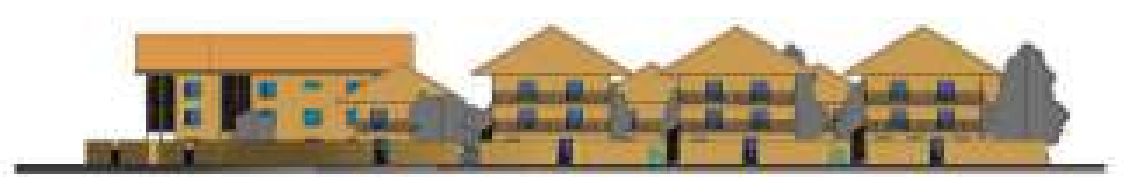

West Elevation 1:1000

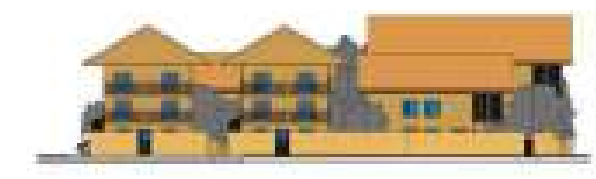




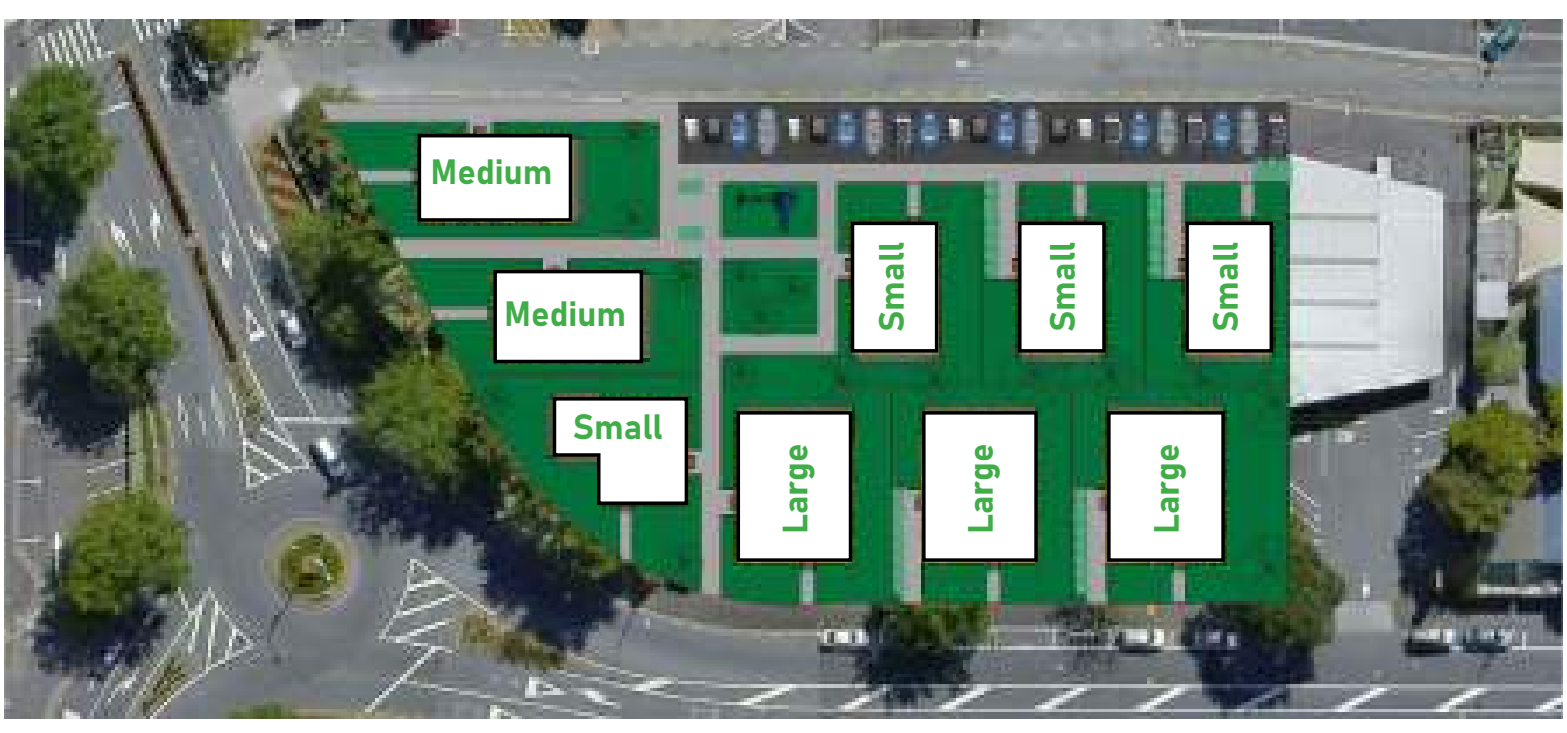

The proposed design incorporates different accommodation sizes and a car park on the edge of the site just as the building types offering different sizes of accommodation. It was important for the spacing between each dwelling be carully considered for this design. If the buildings are too close there is decreased privacy and green space and incros fire spreading risk given the flammace ature of the biodegrable materials. However if the buildings are too far apart they lose the additional shelter provided by the eave of the neighbouring building which the bioderada

the north and larger ones to the south. In addition, the

Ground Floor Site Plan

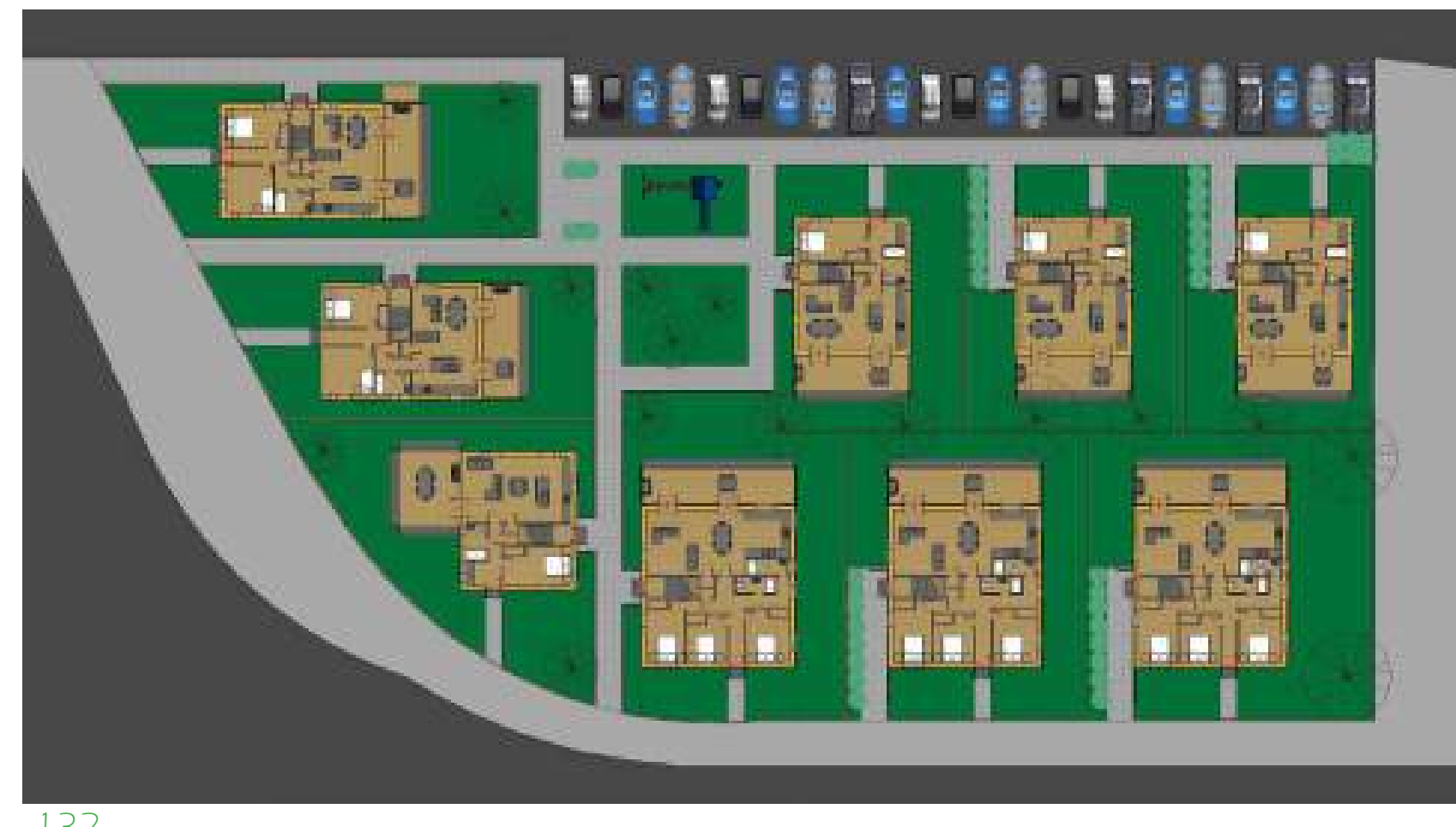

Small $=2 \times$ (one bedroom + one bathroom units). 2-storey building

$x$ (two bedrooms + one bathroom units).

Large $=3 x$ (three bedrooms + two bathrooms). 3-storey

large buildings to the south are offset from the smaller buildings to the north to prevent direct lines of visibility into adjacent units. Trees are also planted between the smaller buildings to the north and larger buildings to the south to improve privacy and amenity.

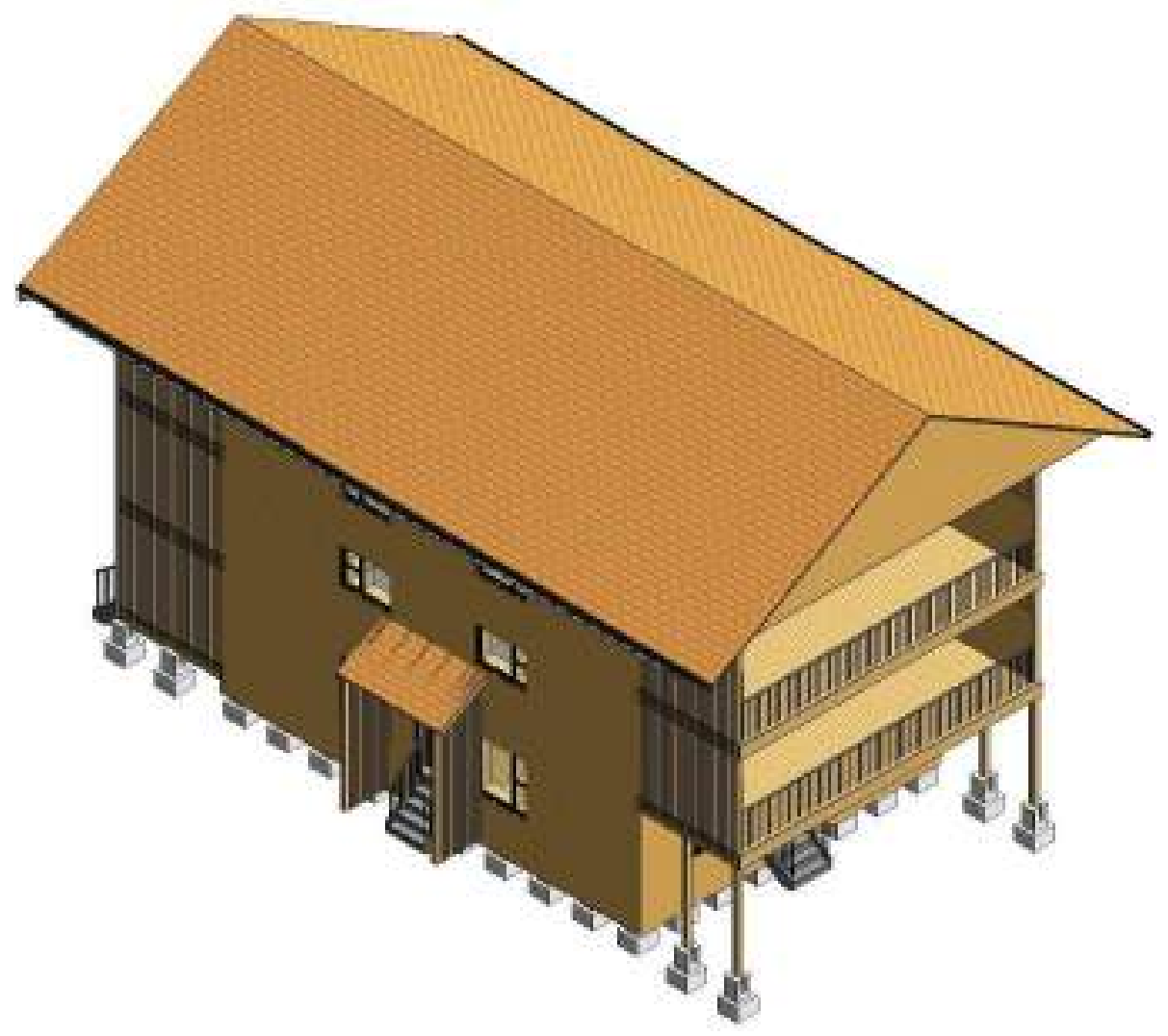

Medium Building Sited Ground Floor 1:200

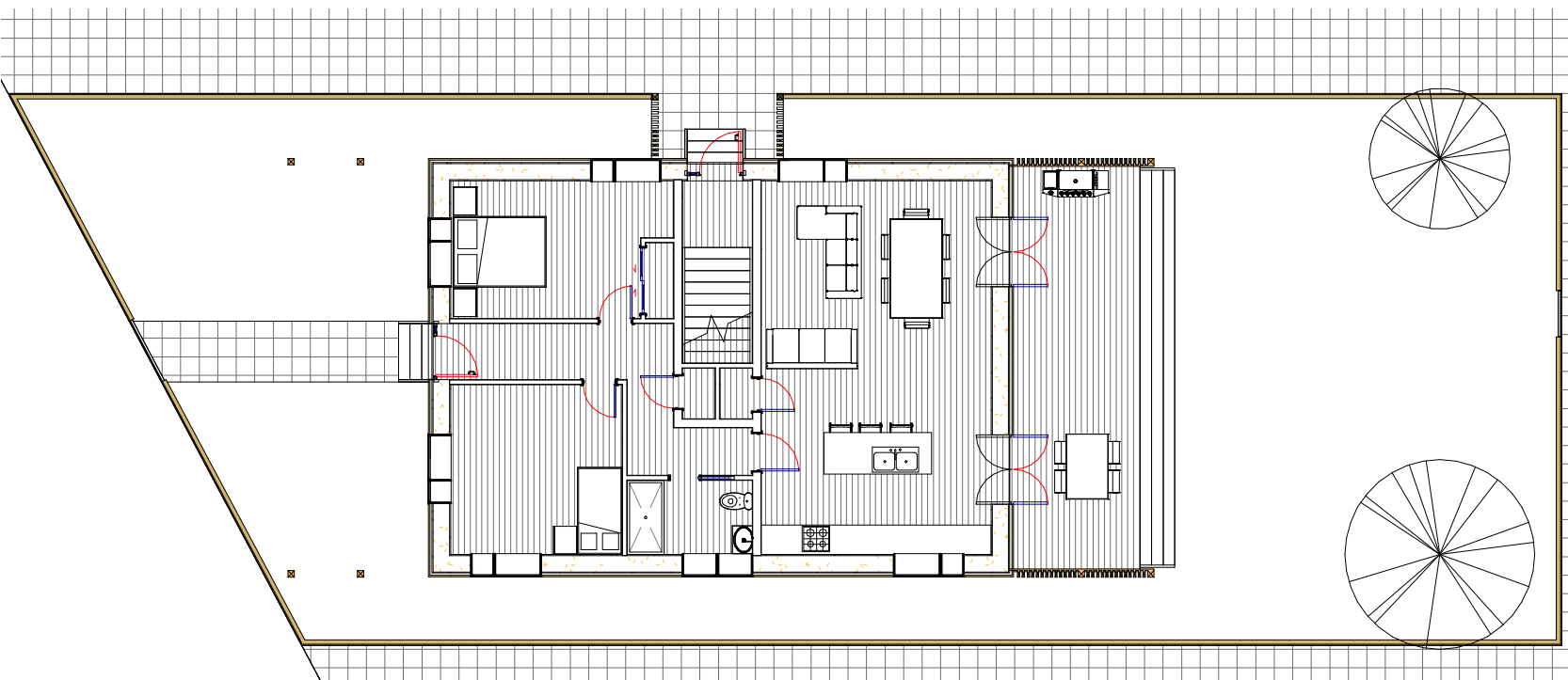




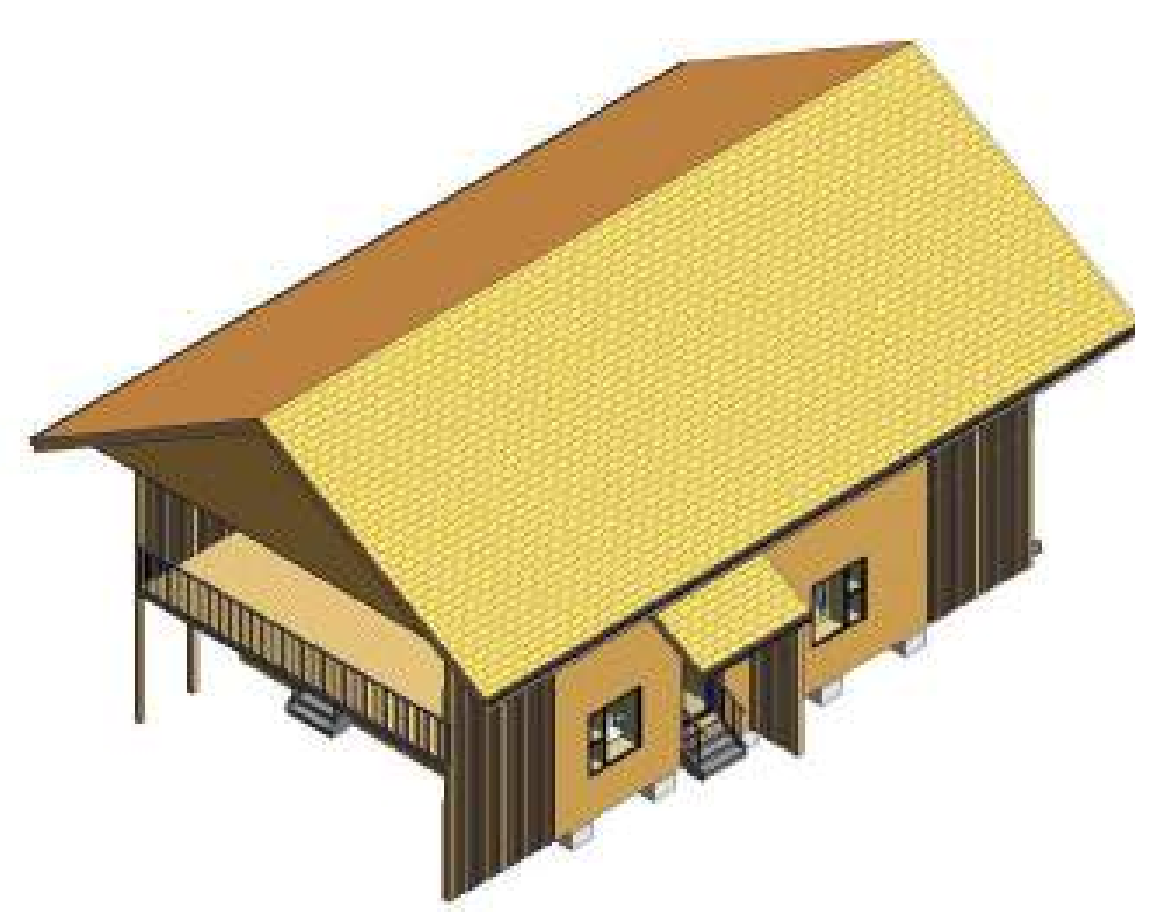

Small Building West Elevation 1:200

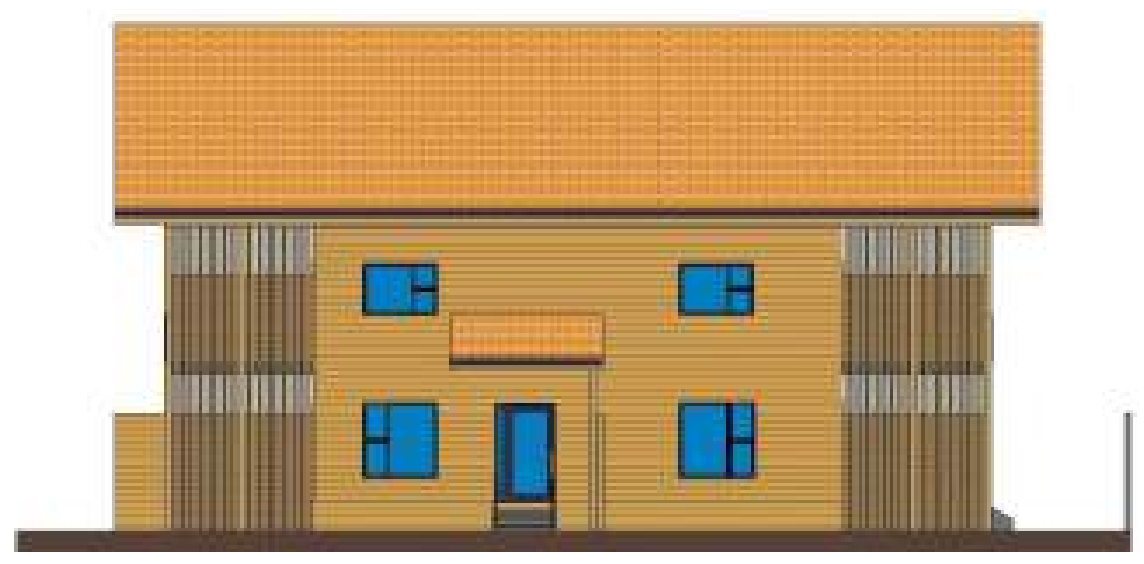

Small Building East Elevation 1:200

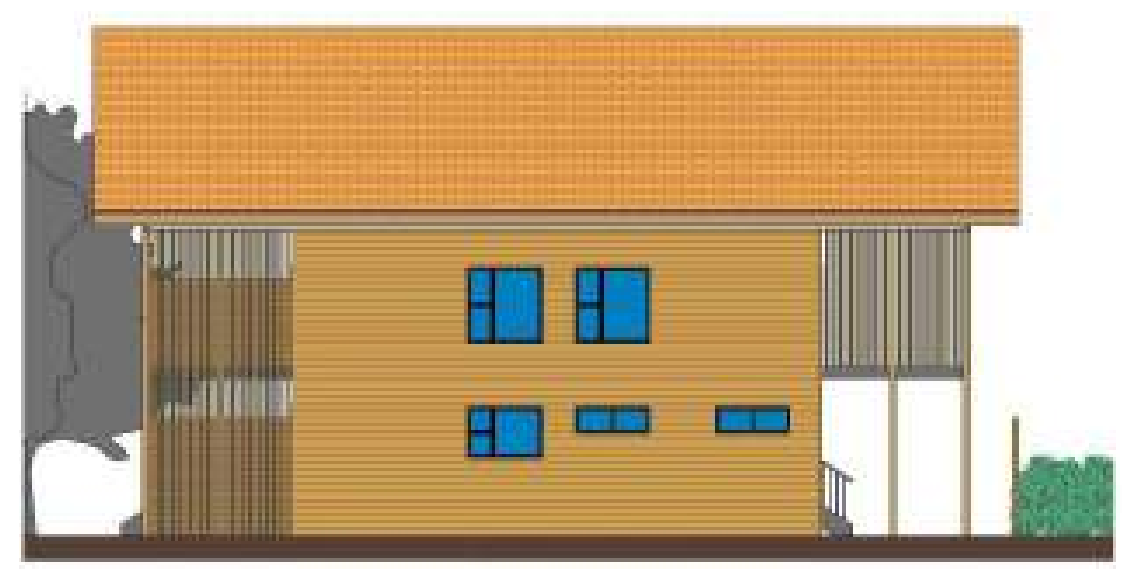

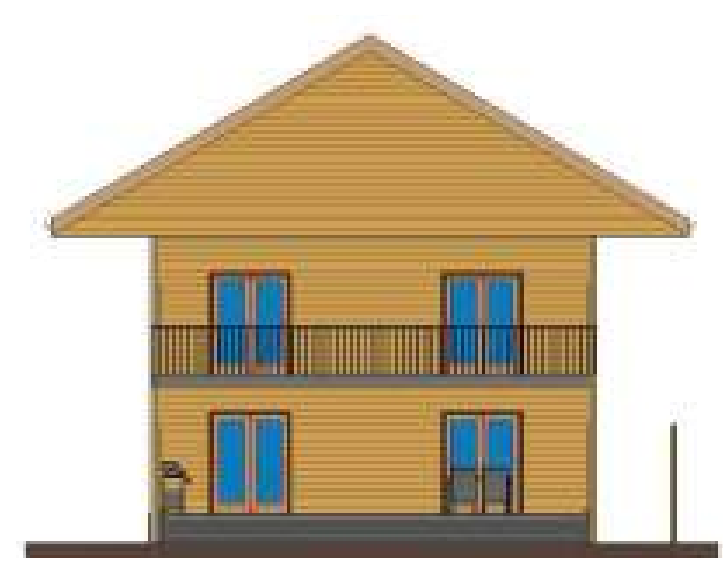

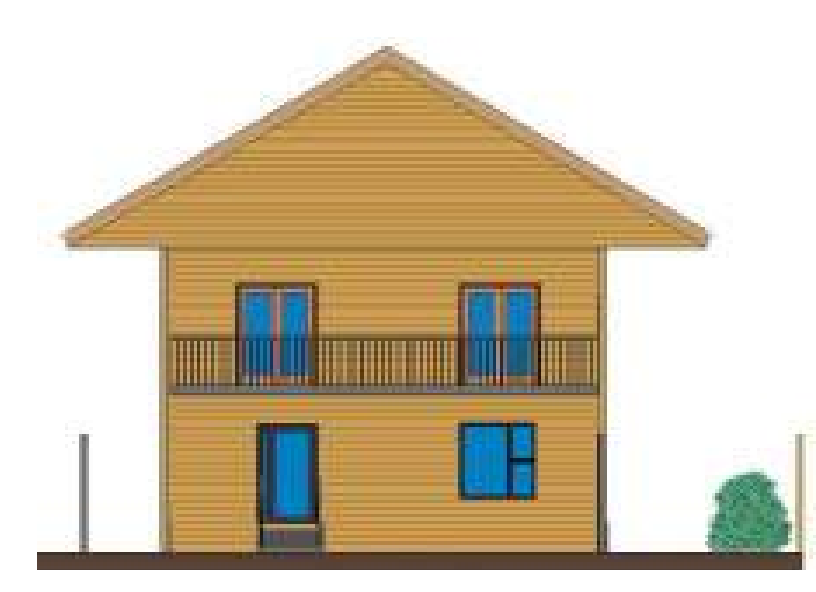

Small Building Ground Floor 1:200
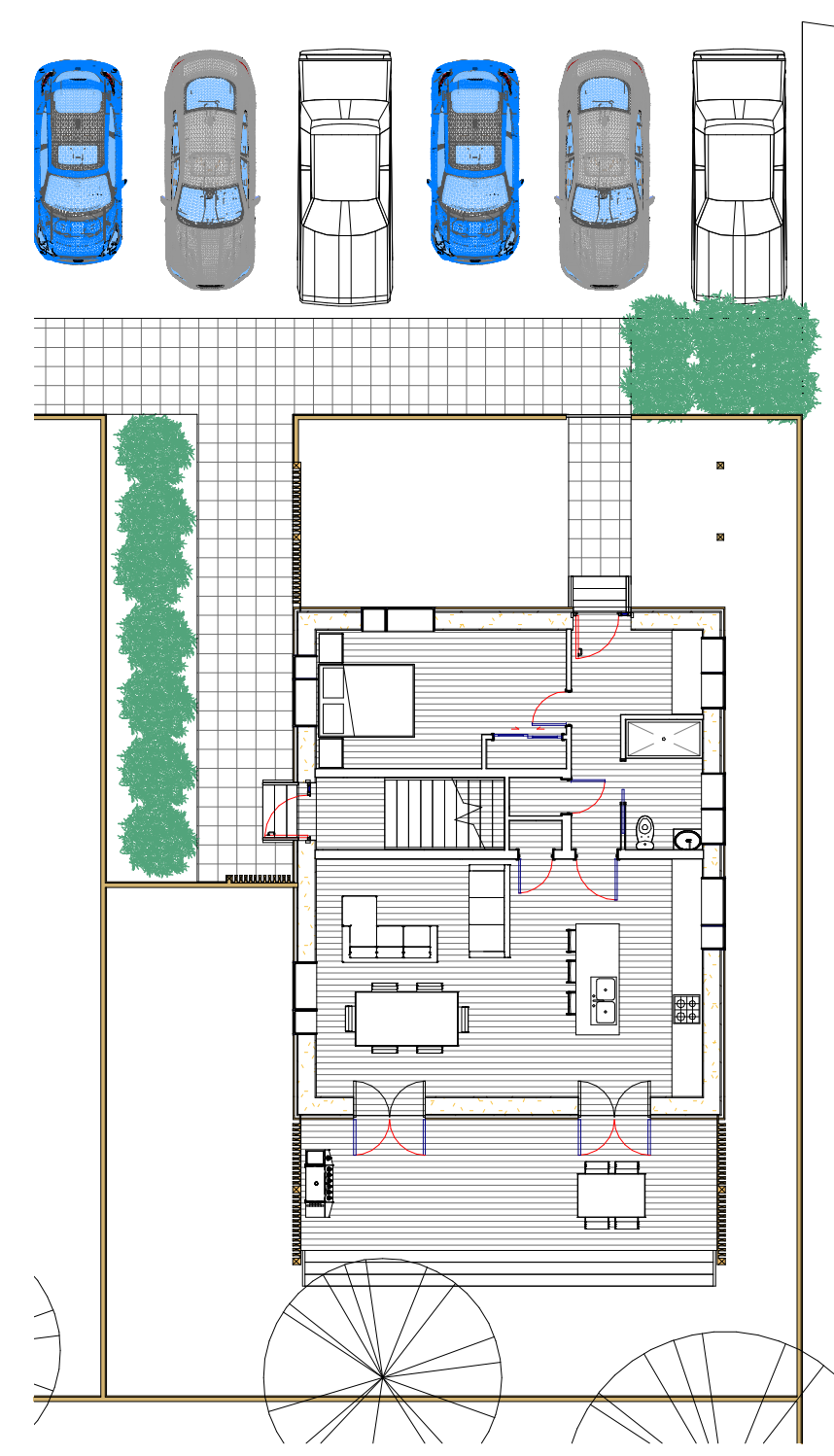

Small Building North Elevation 1:200

Small Building First Floor Plan 1:200

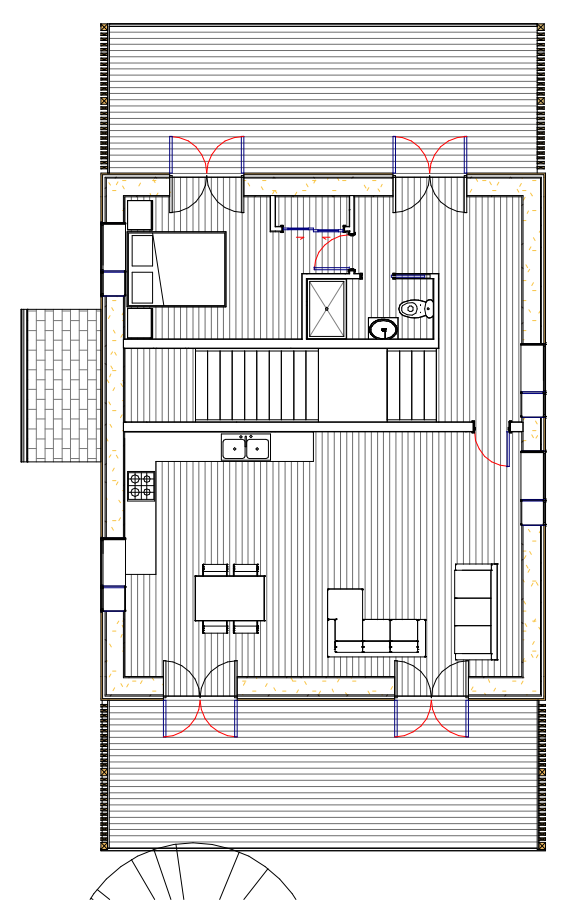


Large Building 1:200

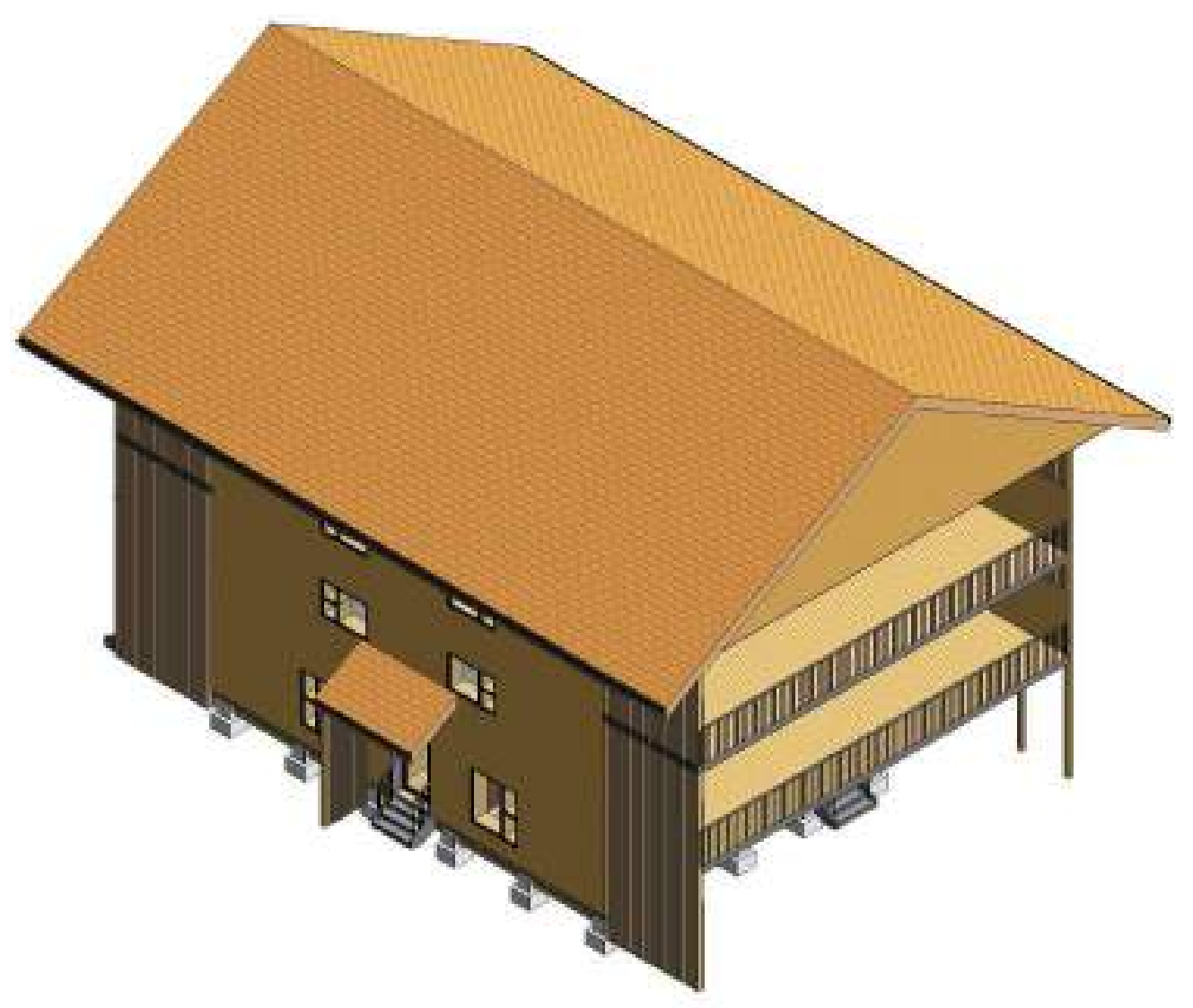

Large Building East Elevation 1:200

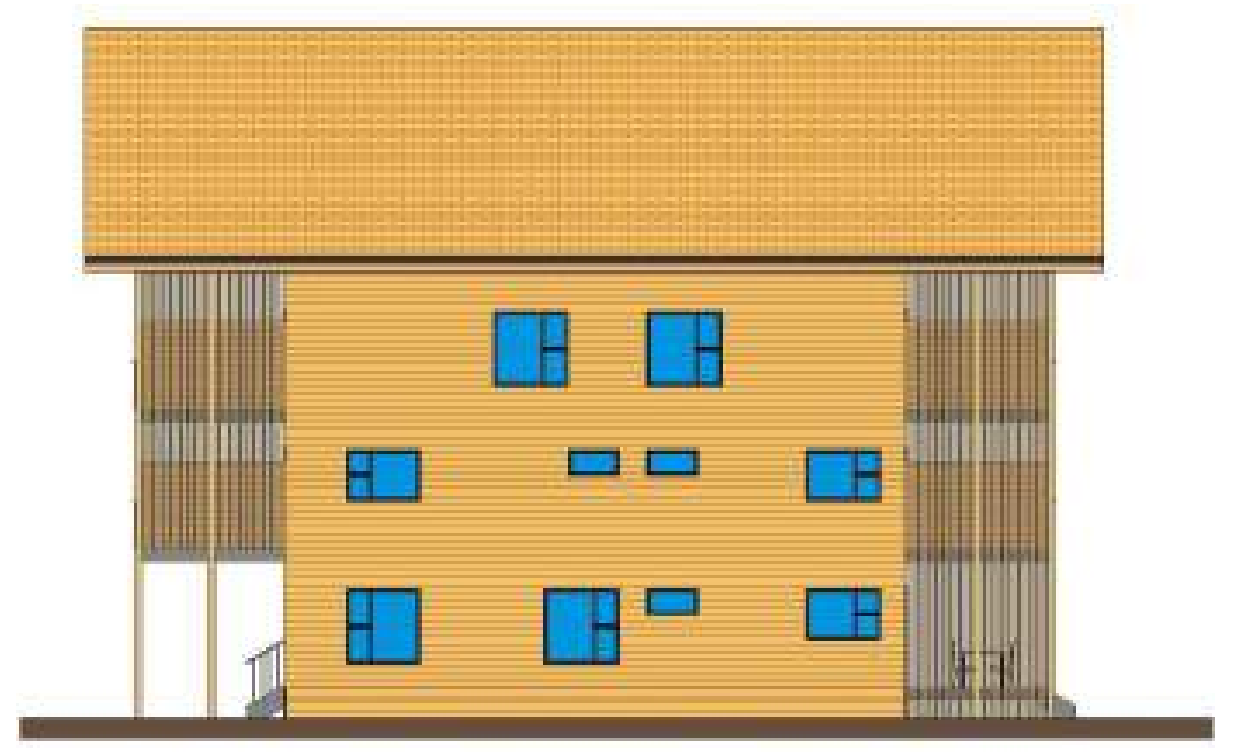

Large Building West Elevation 1:200

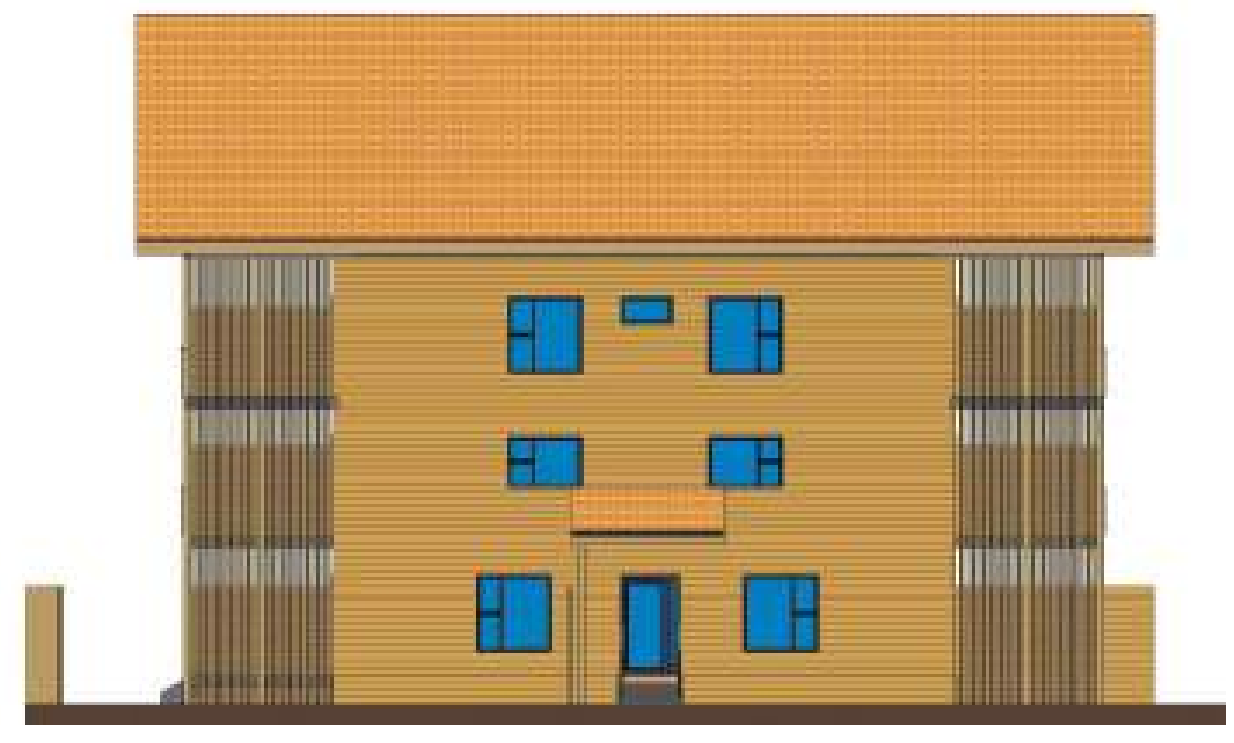

Large Building South Elevation 1:200

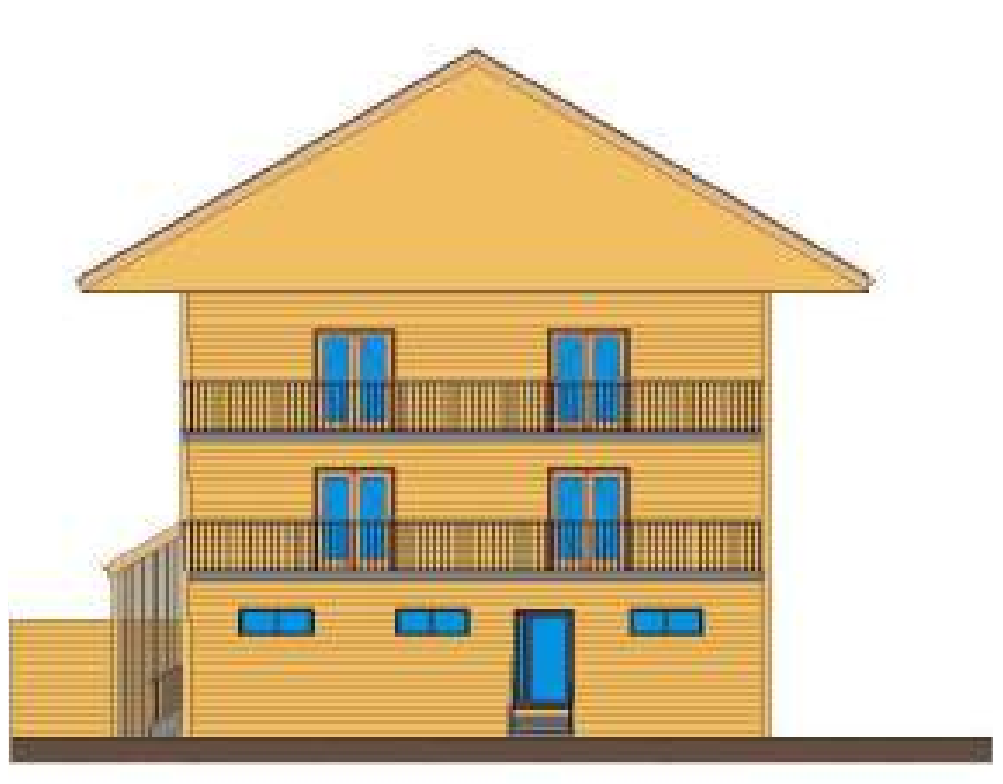



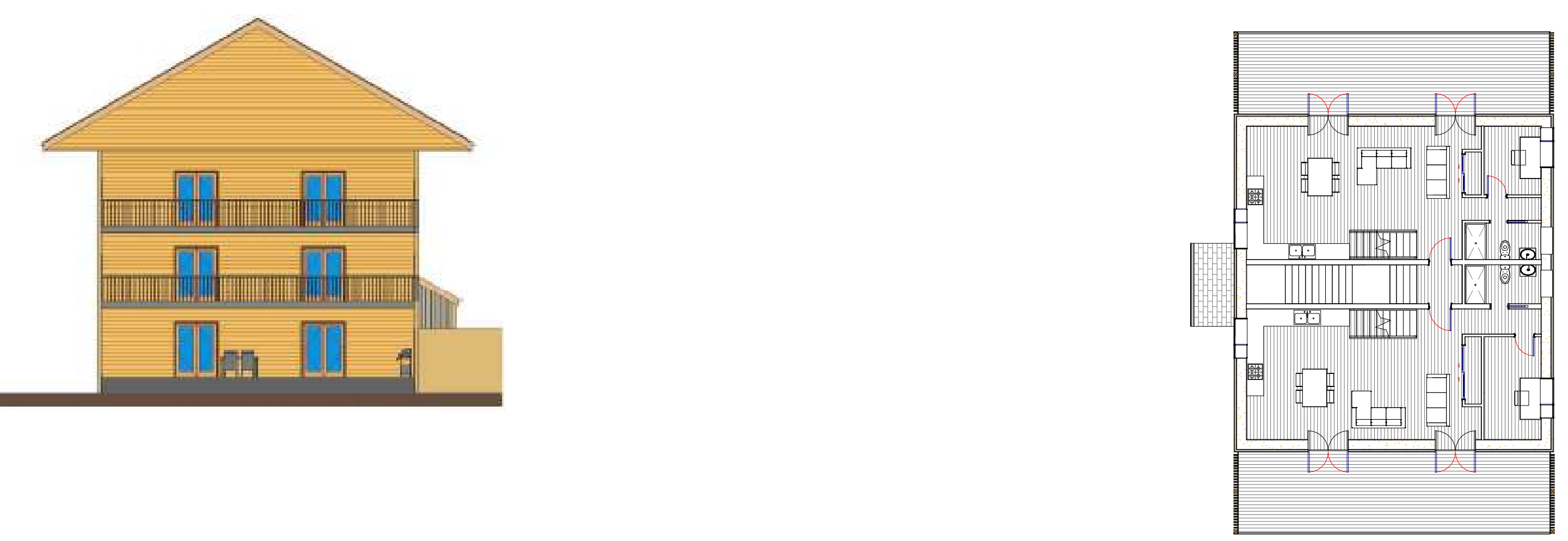

Large Building Ground Floor Plan 1:200

Large Building Second Floor Plan 1:200
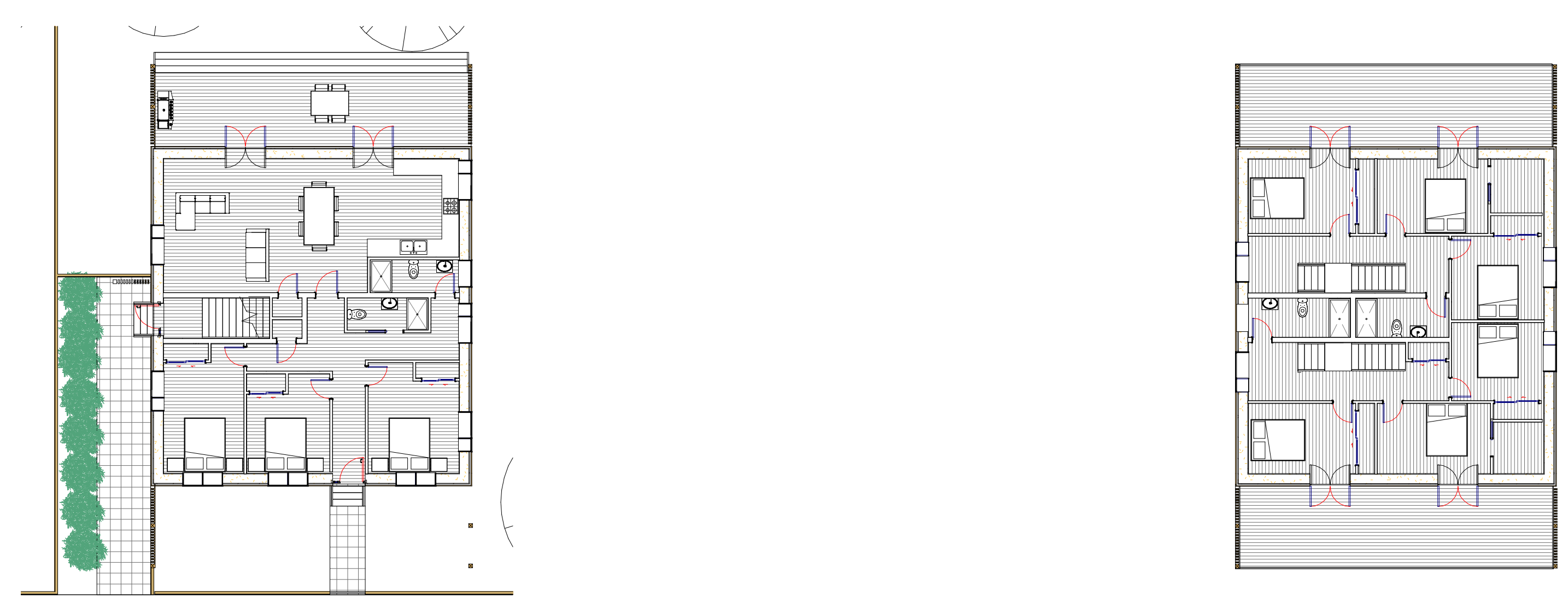
Detailed Design

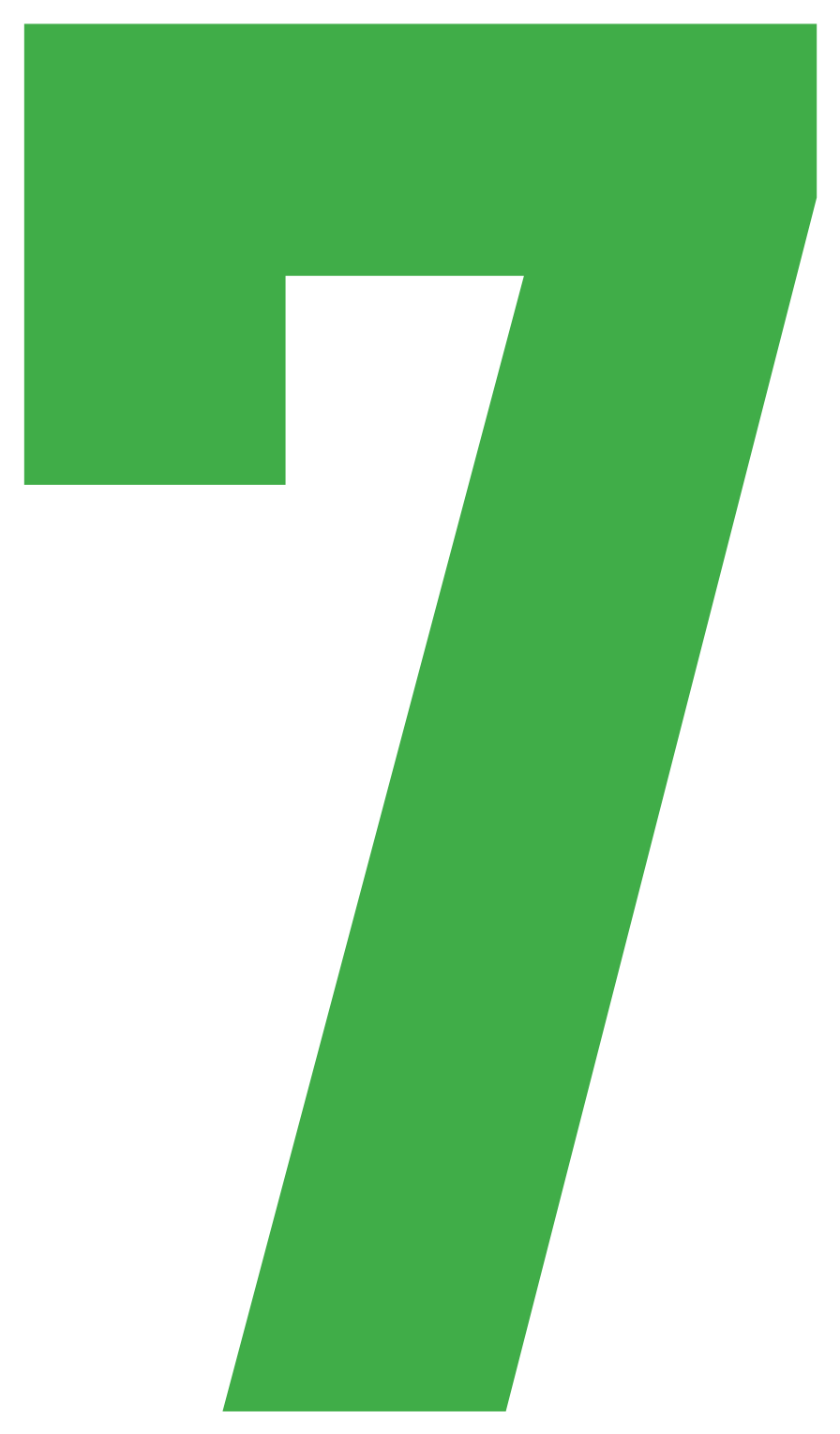




\section{Chapter Outline}

In the previous chapter, the building design was integrated on site to ensure the design functioned sufficiently as a medium density housing development. In (his chapter the construction of the medlum building (concept 3 ) is designed in detail. This is done to accurately assess the quantity of waste diverted from landill and the end of life of the building and the proportion of biodegradable materials in the construction. Precedents and literature

of the prefabricated straw and wool insulated pane from chapter 4 into the design. A detailed BIM model is then produced of the entire building from which volumes can be extracted. The material components are the categorised regarding their biodegradability, reusability or lack thereof to accurately assess the first two thesis objectives. The same assessment is undertaken for an identical design but using conventional New Zealan

\subsection{Prefabricated Panel Development and Integration}

Precedent and Literature Review

Figure 68

Figure 69

Diagonal Braces

Buried brace
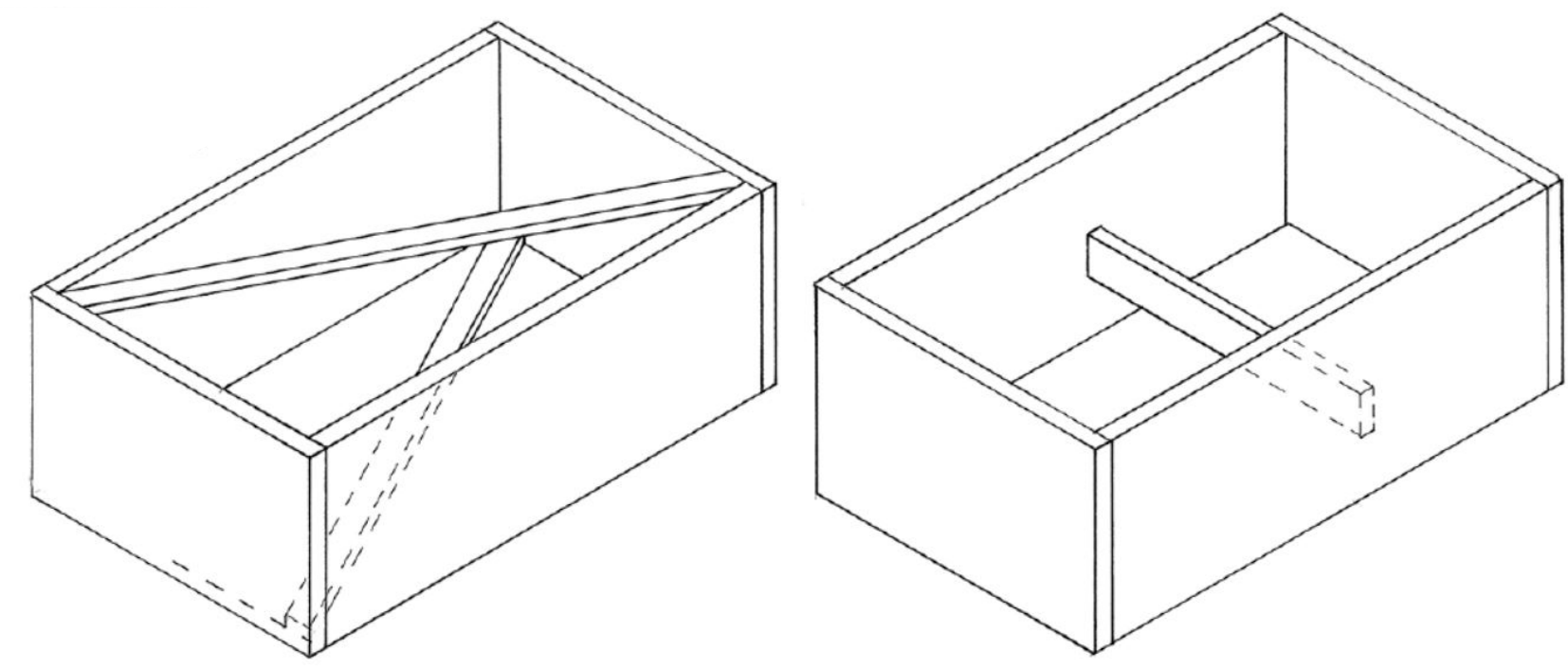

"Reprinted From "ESSentia Prefab Straw Bale Construction. The Complete Step-by-Step Guide" by C. Magwood, 2016, p. 16. Copyright 2019 by Chris Magwood

\section{Figure 70}

Ecococon panel to floor connection

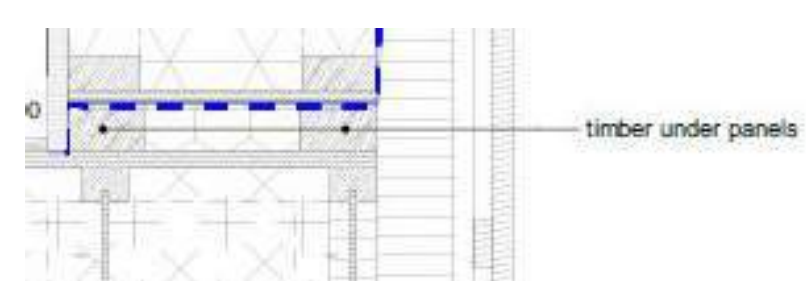

\section{Figure 71}

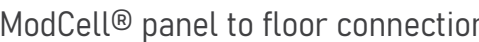

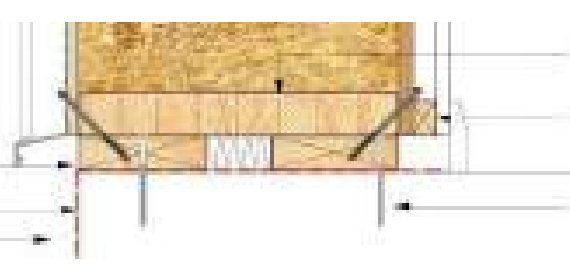




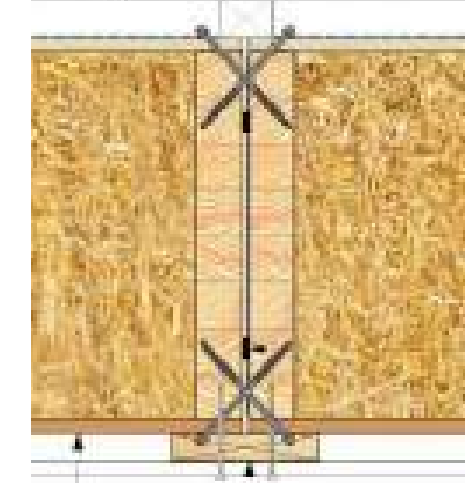

Figure 73

Haslacher timber connector

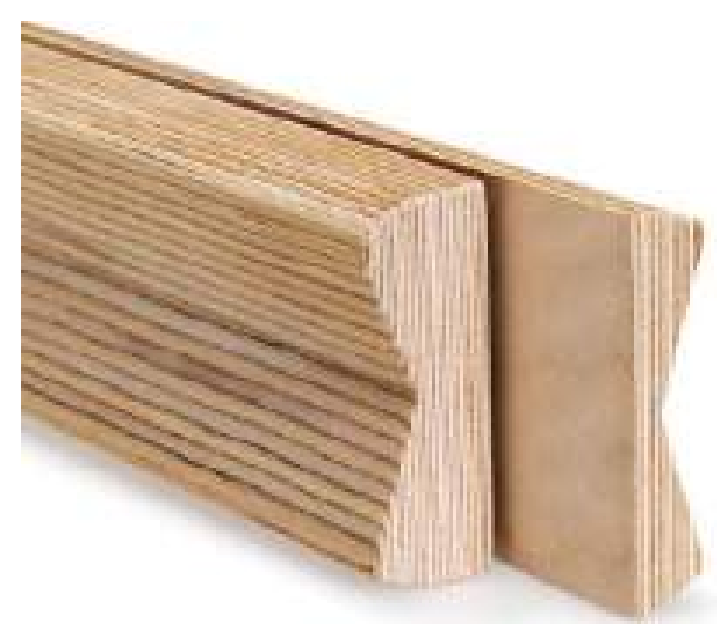

The prefabricated panel design from concept 3 requires further development before it can be integrated into the building design. One area of required development is bracing. Magwood explains that straw insulated prefabricated panels can be braced by diagonal braces (figure 68) or a buried brace (figure 69) (Magwood, 2016). Diagonal braces provide the most effective bracing whilst the buried brace allows the brace to span across the whole panel not just between vertical members of the frame (Magwood, 2016). The buried brace's ability to span the brace.

Another required area of development for the panel is its connection to floors. Both Ecococon and ModCell $\otimes$ panels

\section{Figure 74}

Haslacher timber connector details

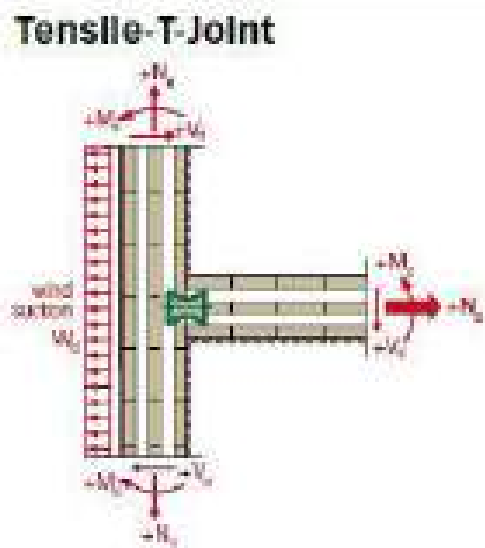

Tenslle-corner-joint 45 "

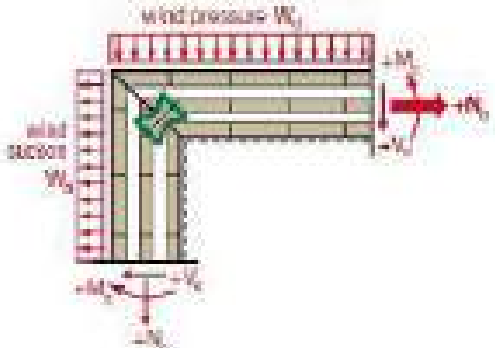

are connected timber runners which are in turn fixed into the floor (figure 70.71). In both cases, insulation is also used in the cavity.

Finally, how the panels connect to each other needs to be developed. The ModCell ${ }^{\circledR}$ panel (figure 72) and the Ecococon panel both connect to adjacent panels with screws. However, opportunities for biodegradable connectors exist as an alternative to screws such as the conber connector from Haslacher (figure 73,74). These removed at the end of life as easily as a screw.

\section{Panel Design Proposal}

The proposed panel design utilises a buried diagonal brace that combines the two bracing options explored in the precedents. Timber runners are used as a fixing method to the floor as the precedents demonstrate, and pure woot insulation is used to insulate the cavity. Finally, timber connectors like that from Haslacher are used to connect the panels together.

The panels are integrated into the envelope of the building such that the width of the panels are aligned the building were slightly manipulated to achieve panels

widths of increments of $600 \mathrm{~mm}$ (the use of compressed straw in the panels allows dimensional flexibility). $600 \mathrm{~mm}$ was chosen as it is a dimension of a standard structura grid spacing for residential buildings.

The "Multi-Storey Light Timber-Framed Buildings in New Zealand - Engineering Design" from BRANZ specifies $140 \times 45 \mathrm{~mm} \mathrm{SG8}$ wall studs at $600 \mathrm{~mm}$ centres for a worked example of a 4-storey building (Carradine et al., 2019). The proposed design in this thesis is only 3 storeys but has a considerably heavier construction therefore 200x100 stud members were selected to be conservative.

\section{Panel to Floor Detail 1:20}

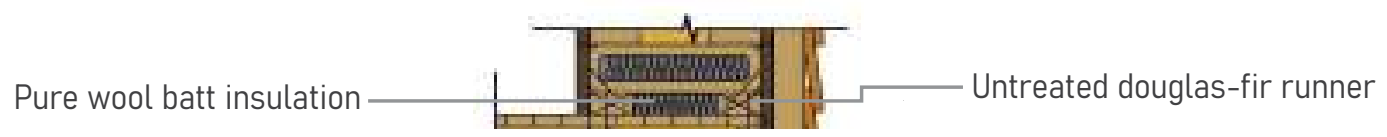

Wall Panel Corner Detail 1:20

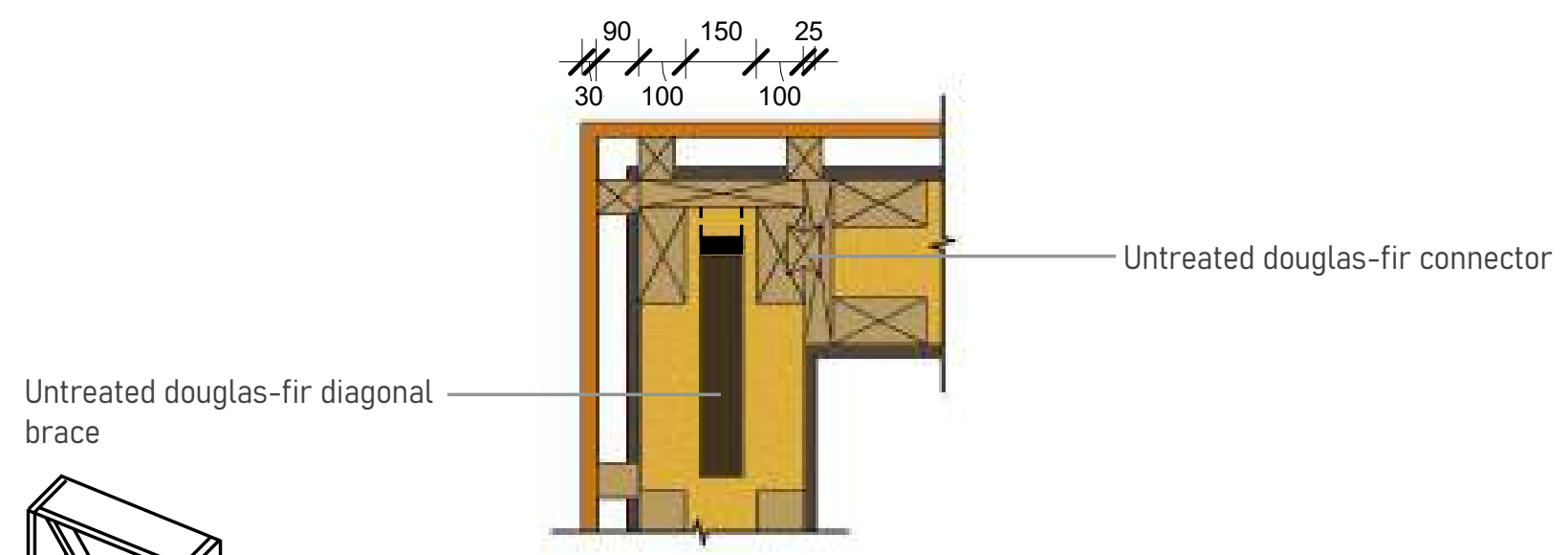

Wall Panel Connection Plan Detail 1:20

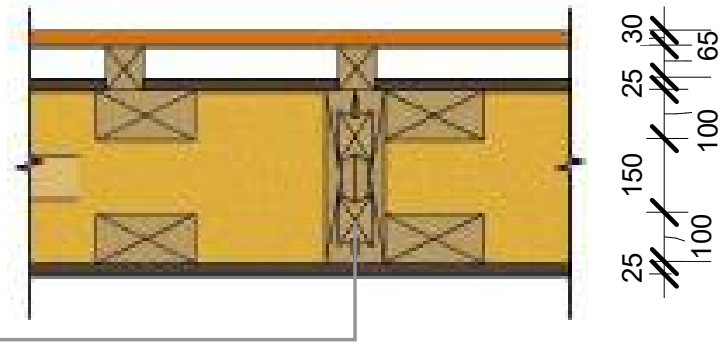



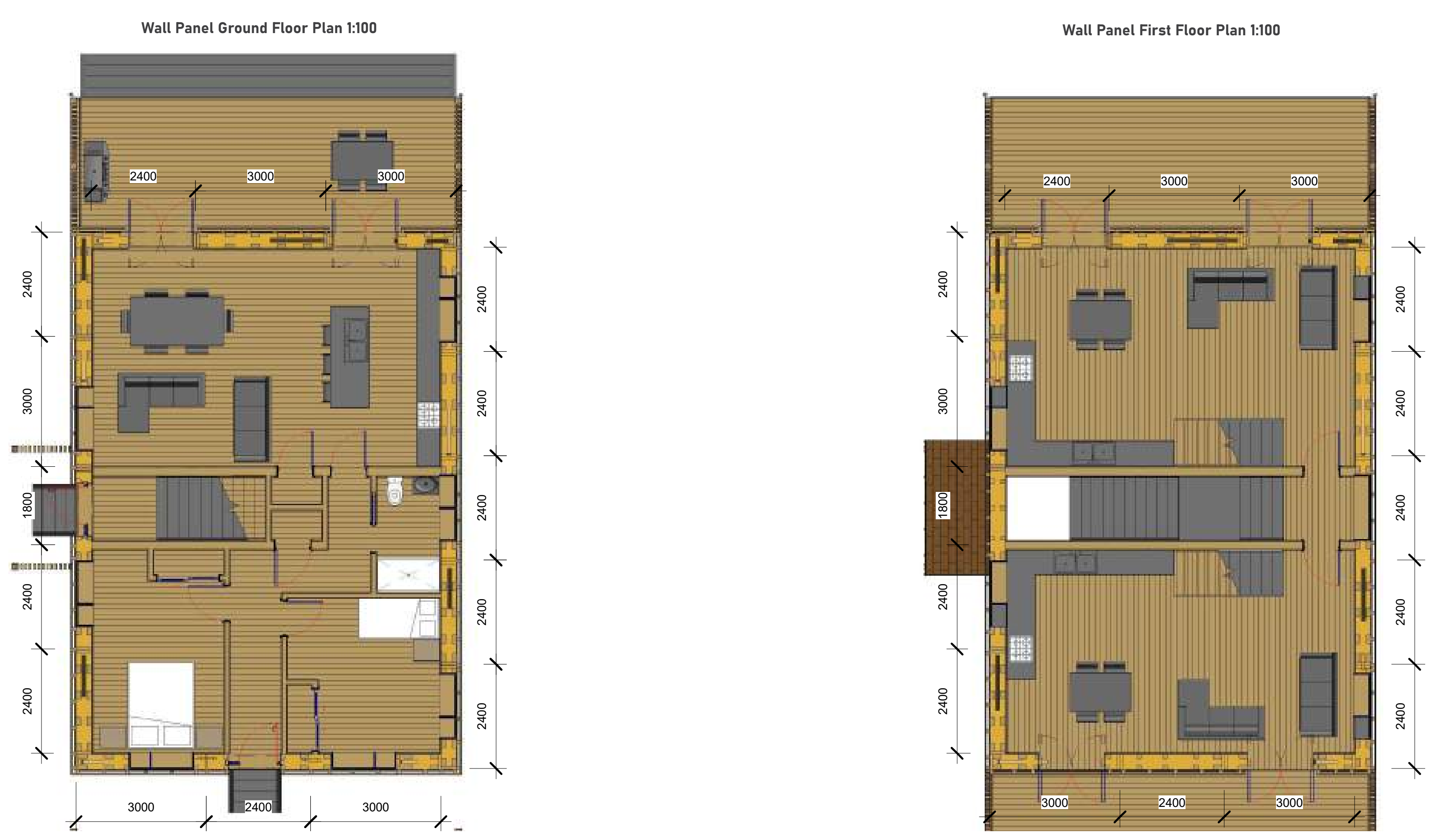

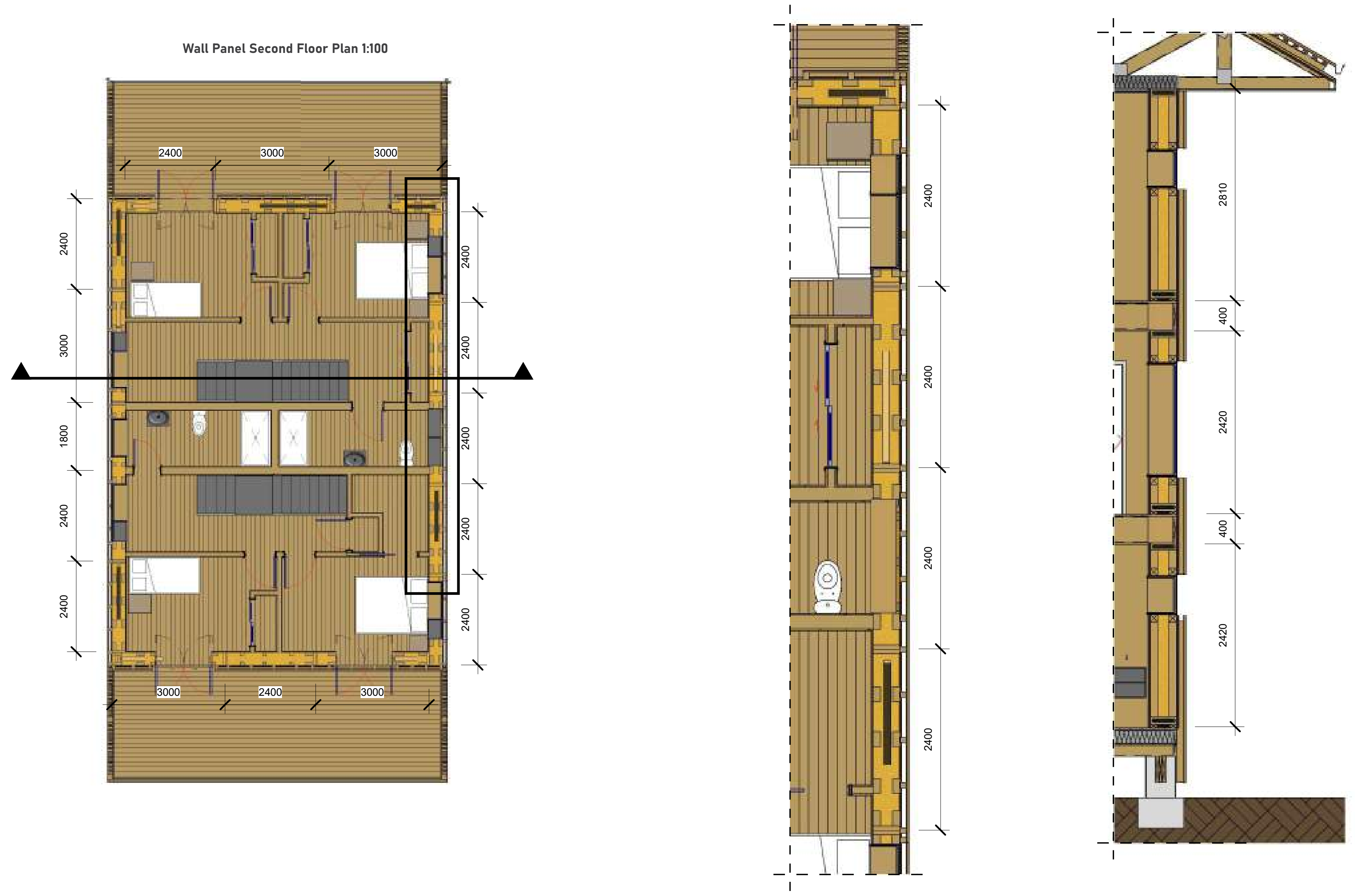


\subsection{Final Design and Conventional Design}

\section{Comparison}

In this section of the chapter the rest of the building's that the most suitable biodegradable or reusable construction is designed and compared with conventional New Zealand residential construction. It is in this section

\section{Final Design}

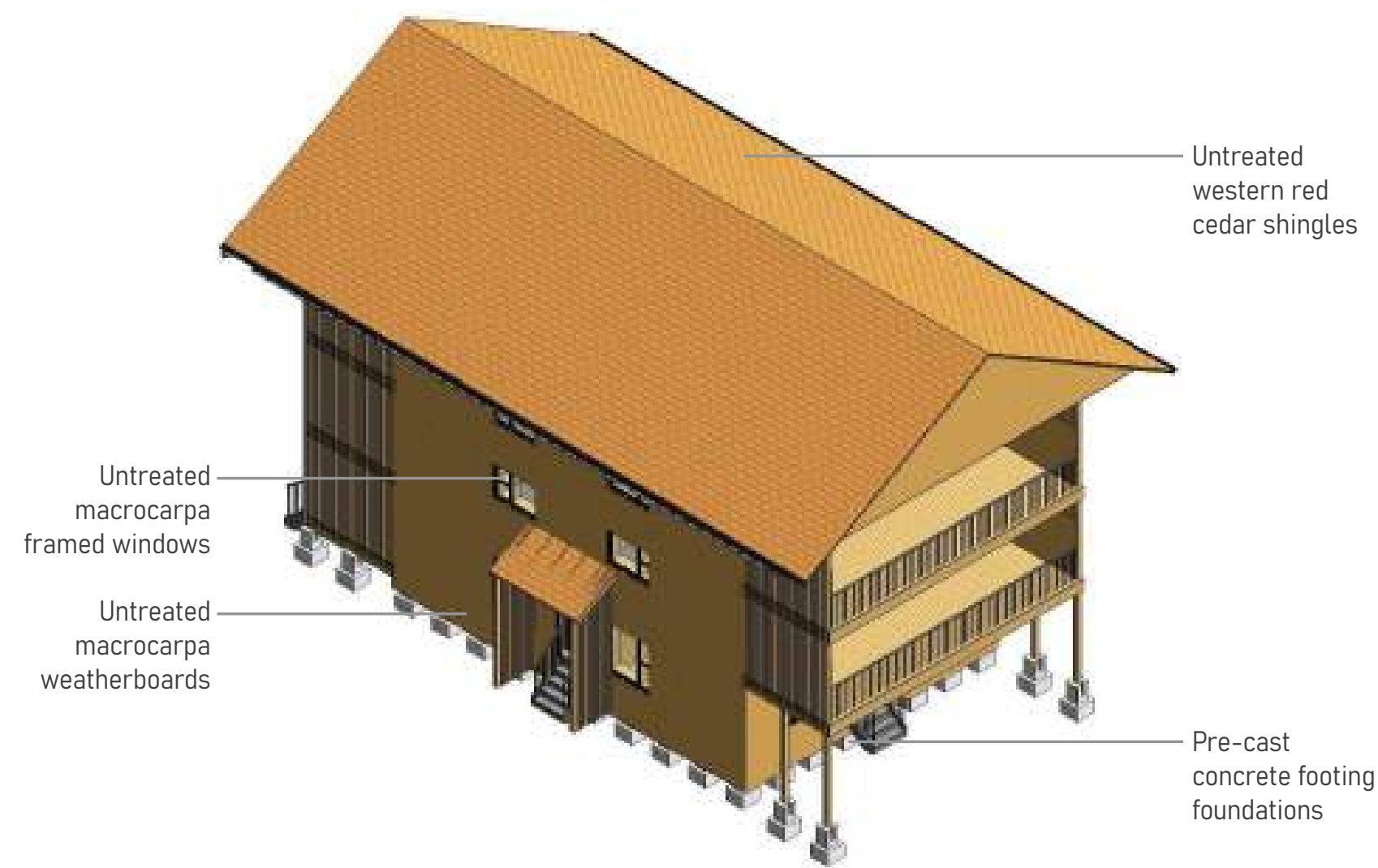

The final design is the building design from this thesis with the objective of eliminating end of life waste and maximising the use of biodegradable building materials
Final Design with Conventional New Zealand Materials

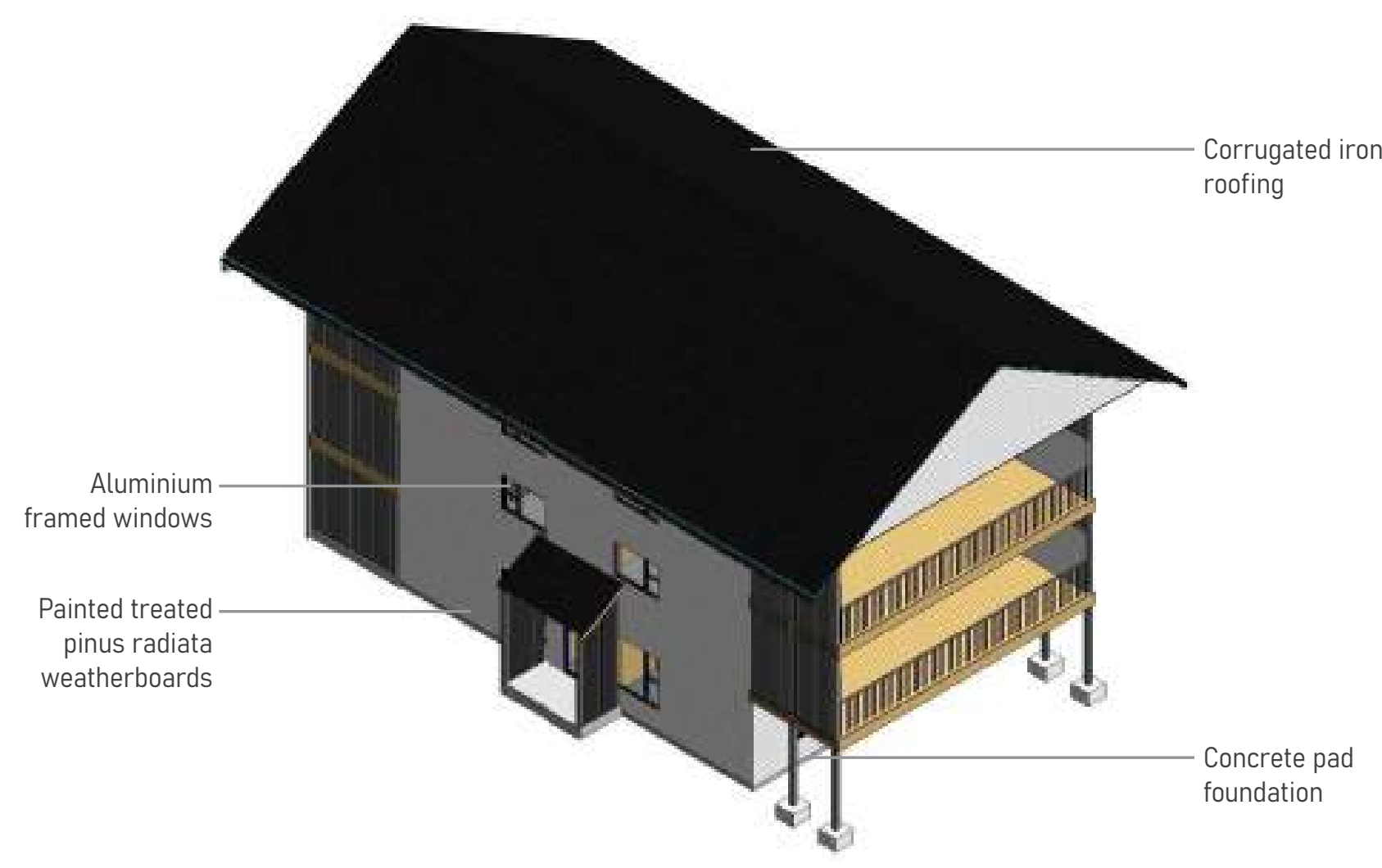

The final design with conventional New Zealand materials is identical in design to the final design but with conventional New Zealand materials and construction techniques. Literature was used to inform which materials were most popular in homes in New Zealand (see page 165 for references) 

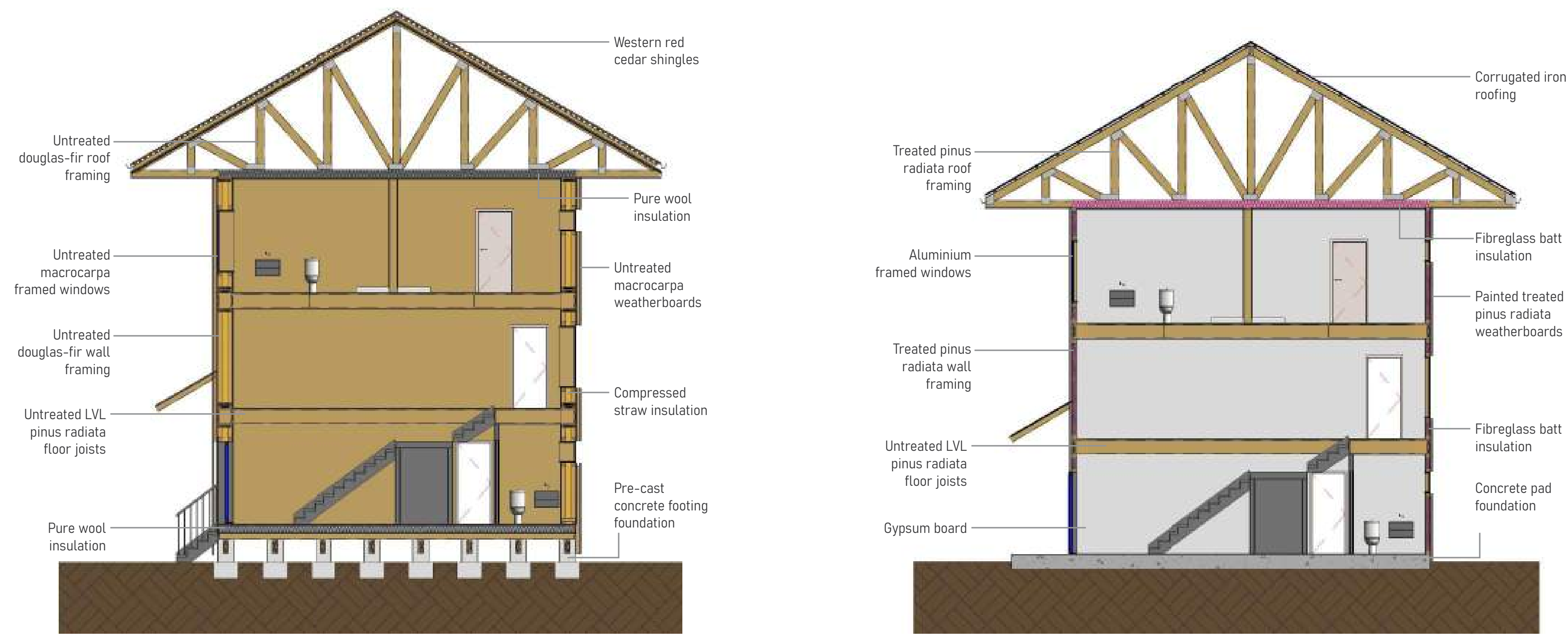

Because wool is less dense than straw it was used to insulate the roof to minimise dead load. Wool was also used for underfloor insulation as it is simpler to place between joists than compressed straw, loose straw or resized bales. 


\section{Final Design}

Untreated LVL pinus radiata hollow box _ Inter-storey Detail 1:20

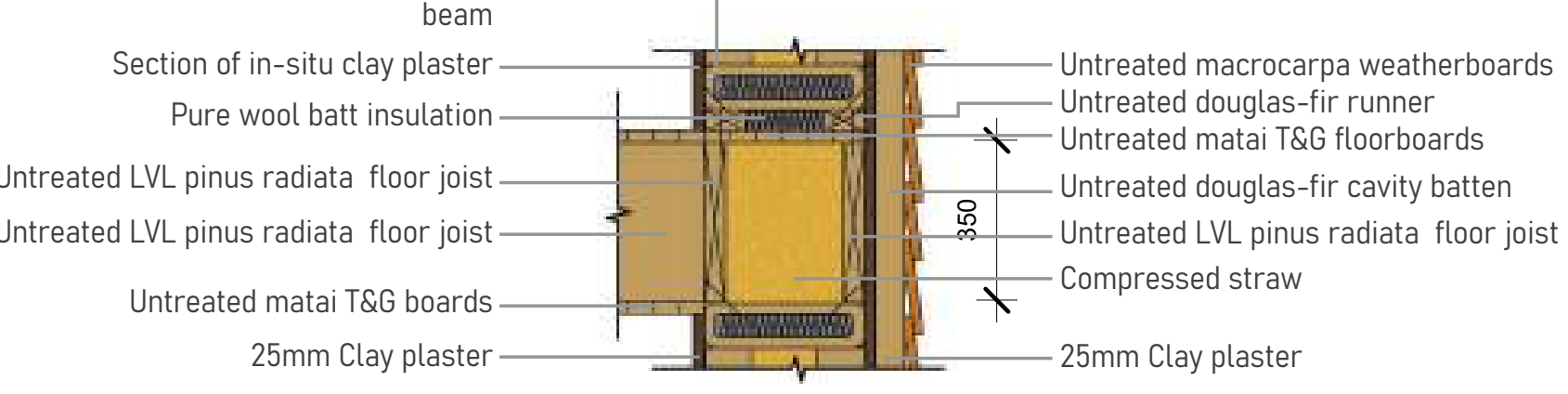

Wall Panel Connection Plan Detail 1:20

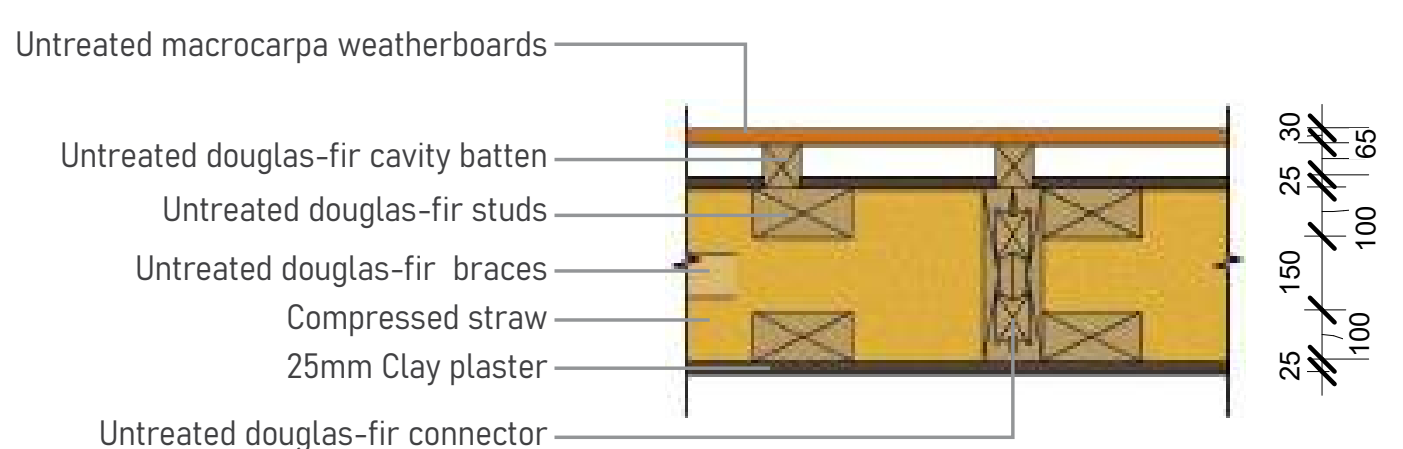

\section{Window Detail 1:20}

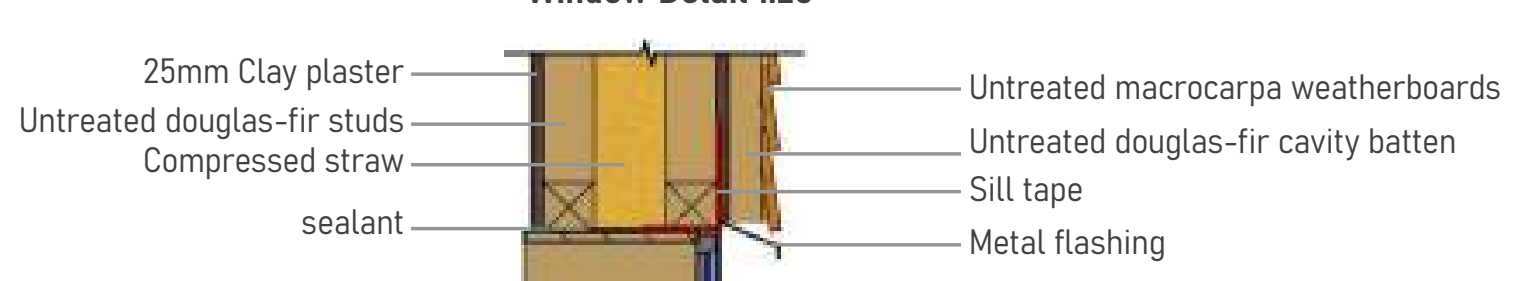

Untreated douglas-fir joinery

\section{Wall Panel Corner Detail 1:20}

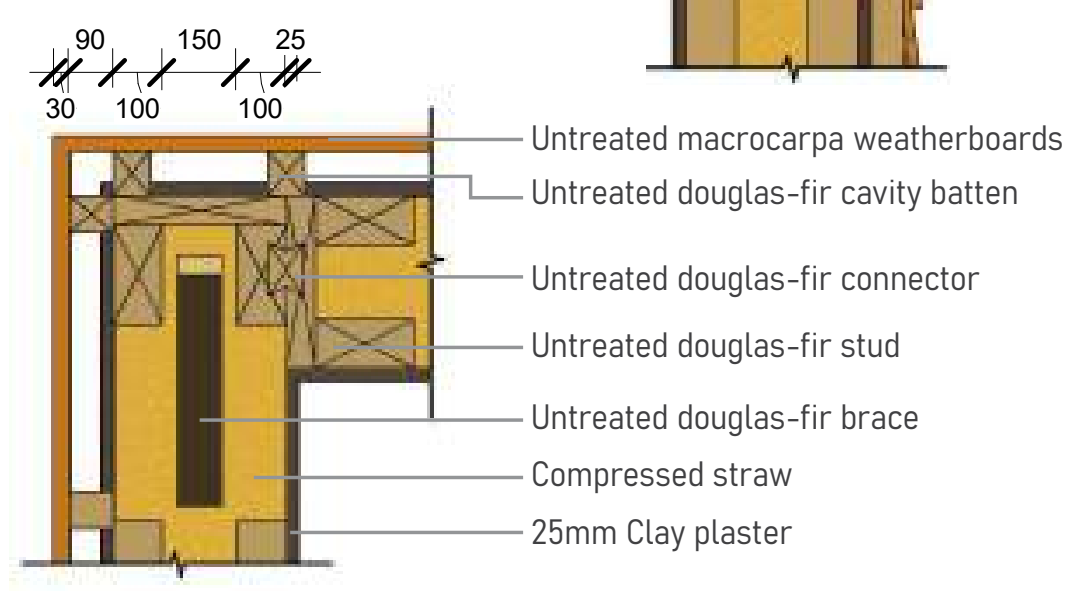

\begin{tabular}{|l|}
\hline Key \\
Untreated douglas-fir \\
Compressed straw \\
Clay plaster \\
Pure wool insulation \\
Untreated macrocarpa \\
weatherboards \\
\hline
\end{tabular}

Final Design with Conventional New Zealand Materials

Inter-storey Detail 1:20

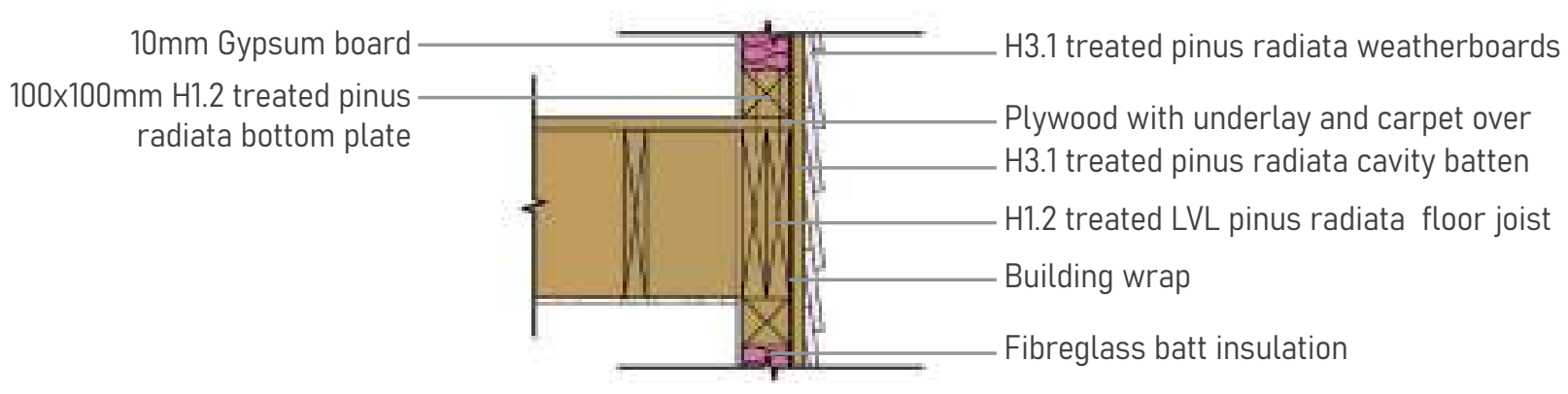

Wall Plan Detail 1:20

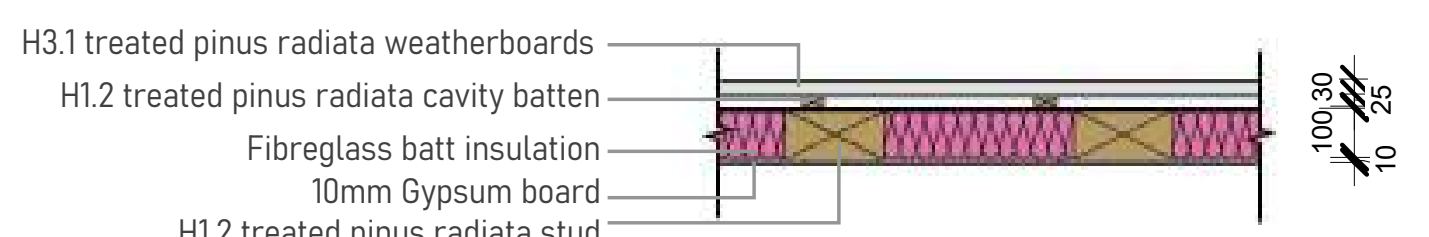
H12 treated pinus radiata stud
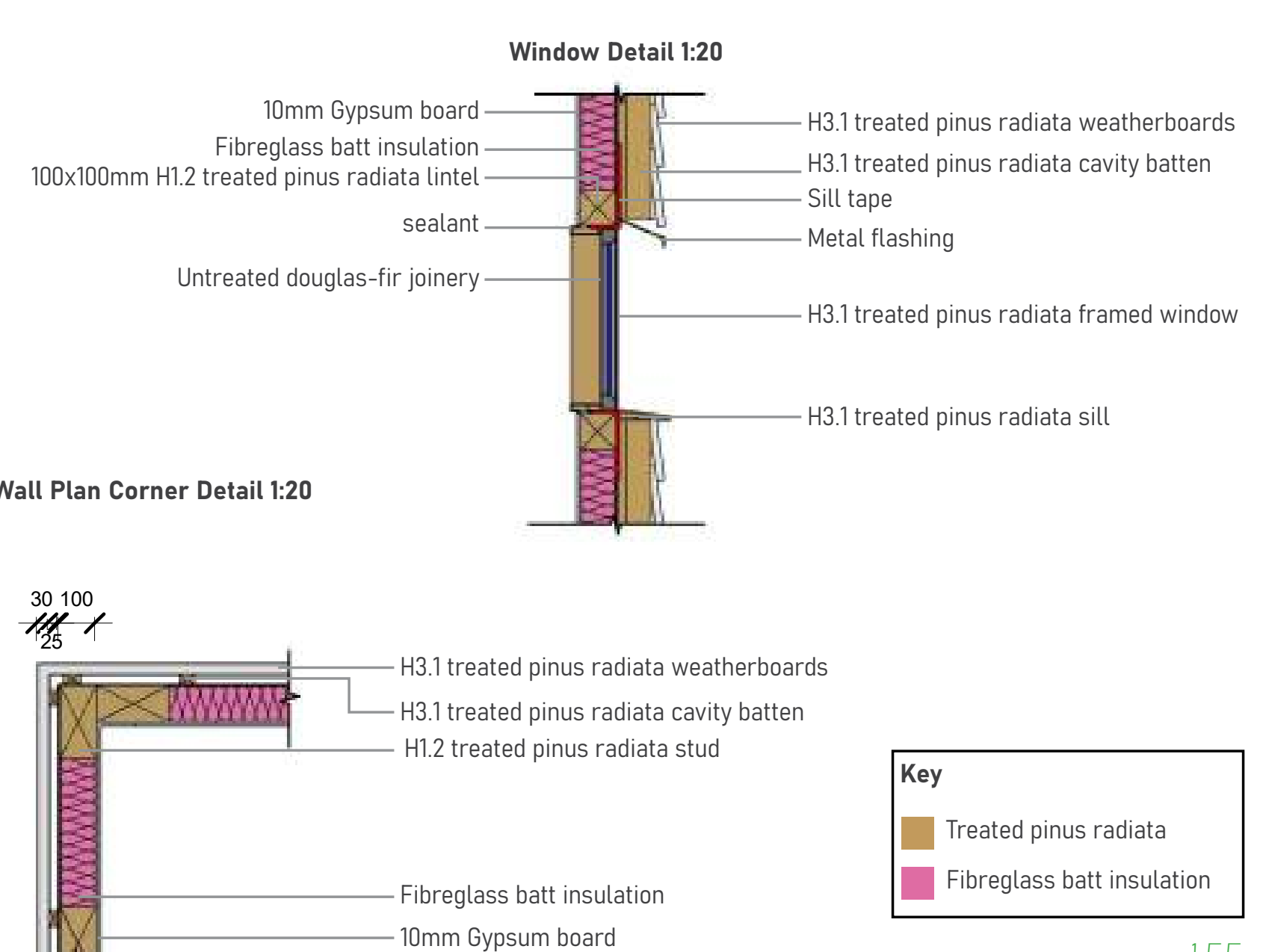
Final Design

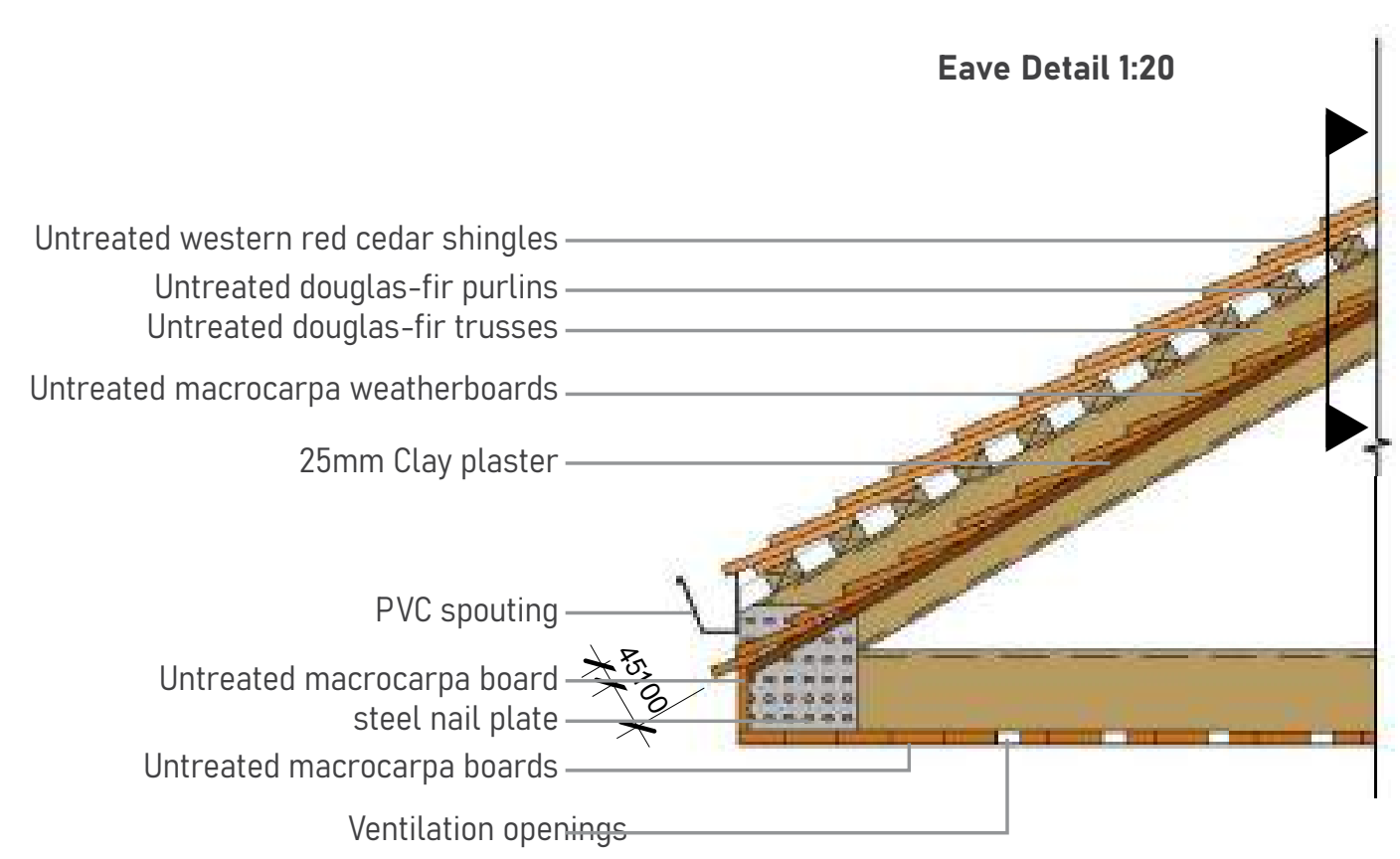

Rafter Detail 1:20

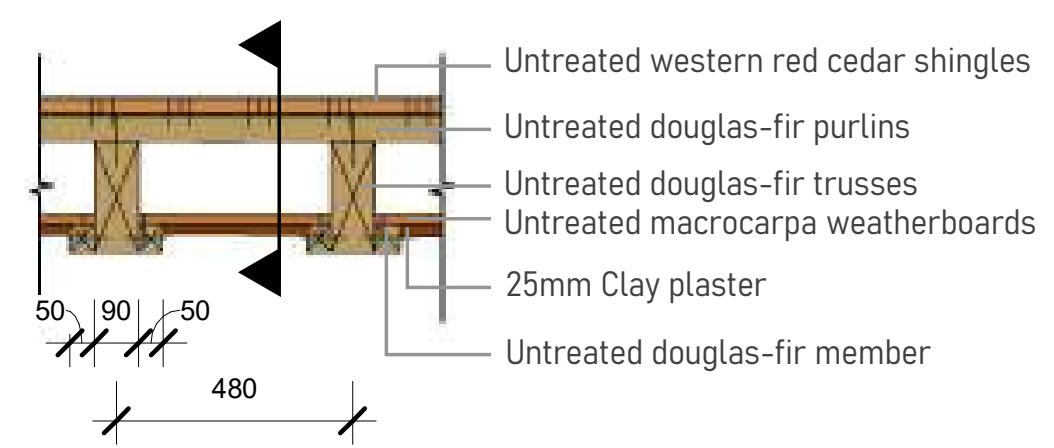

It has been noted that it is difficult to achieve weathertightness for a roof without an inorganic membrane. Given that the roof is also the primary means of deflecting water away from the building it is thoroughty considered here regarding its construction. This roof construction seeks to achieve weathertightness without the use of non-reusable and inorganic materials.

Waterproof membranes operate as the second line of defence against water as good weathertightness design assumes water wil find a way through the first layer, which in this case is cedar shingles. A double tayer of cedar shingles is proposed with a ventilated drainage cavity in between. Clay-plaster is present on the underside of the lower layer of cedar shing pes because its incredible hygroscopic nature would absorb and hold the water that makes it past the wower layser of shingles only to release a against water irftration. Ths strategy would also aid in would not be ceposed to direct rain but at worst a steady supply of moisture within its absorption capability, so the

risk of erosion is eliminated. This approach relies on a very well-ventilated roof space to carry all the moisture out of the roof space.

Regarding the structure of the roof, structural members could not be accurately sized as roof trusses are normally designed by the truss manufacturer. Therefore, members were sized conservatively. Each rafter must span $4.435 \mathrm{~m}$. The smallest spacing of $480 \mathrm{~mm}$ was chosen to be conservative. According to the rafter table (table 10.1) in NZ3504.201 190x 568 ratters can span a maximum of $4.7 \mathrm{~m}$ (Standards New Zealand, 201). the rafters are required to be fixed to the top plate by $2 / 90 \times 3.15$ skew nails +2 Wire dogs to resist uplif (Standards New Zealand 1010) $70 \times 5$ par 10.10) 70x45 purtins are suitable in any wind zone with span no more than (Standards New Zealand, 2011). The heaviest duty fixing required for an extra high win zone is $1 / 14 \mathrm{~g}$ self-driving This fixing is used to be conservative.
Final Design with Conventional New Zealand Materials

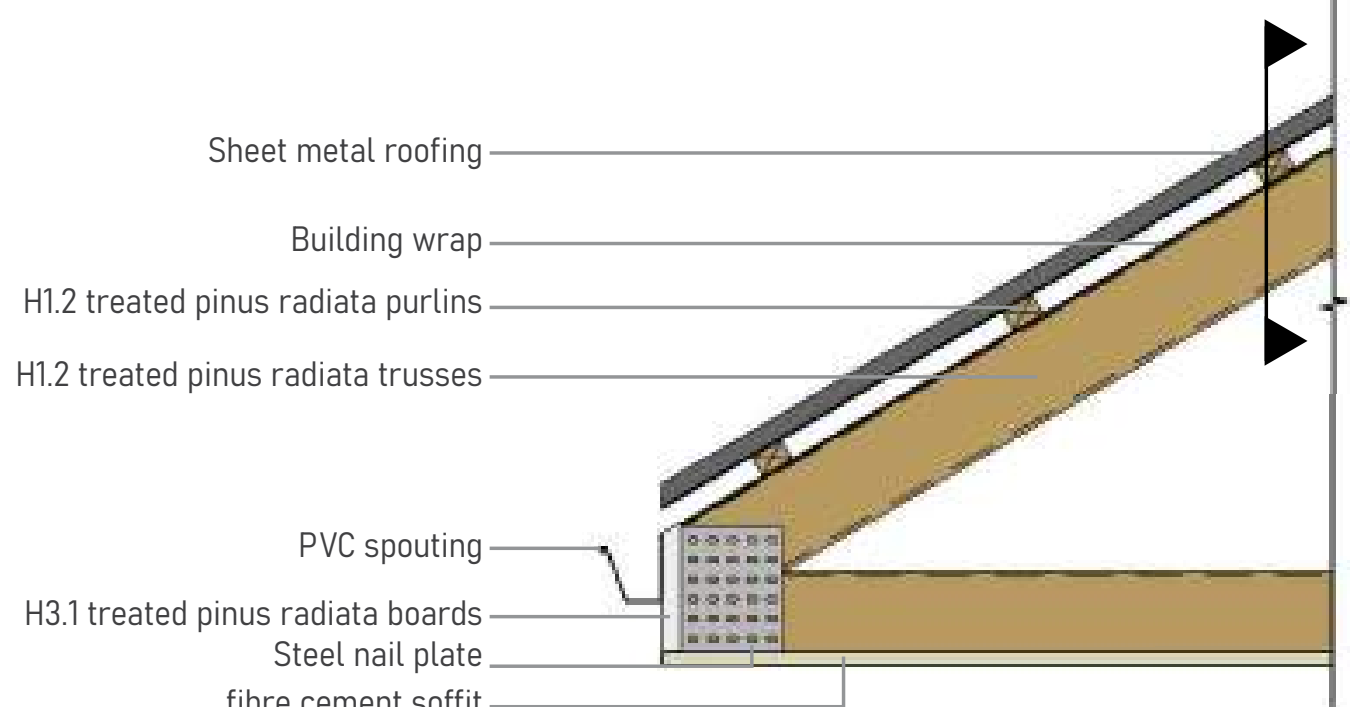

fibre ceme

Rafter Detail 1:20

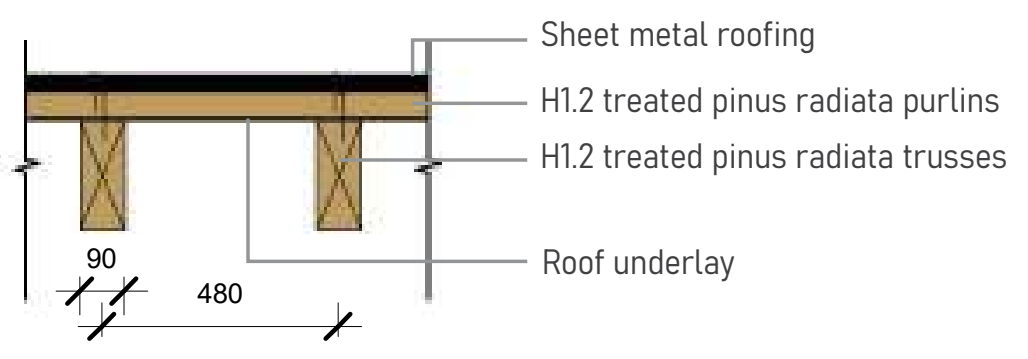

Foundation Detail 1:20

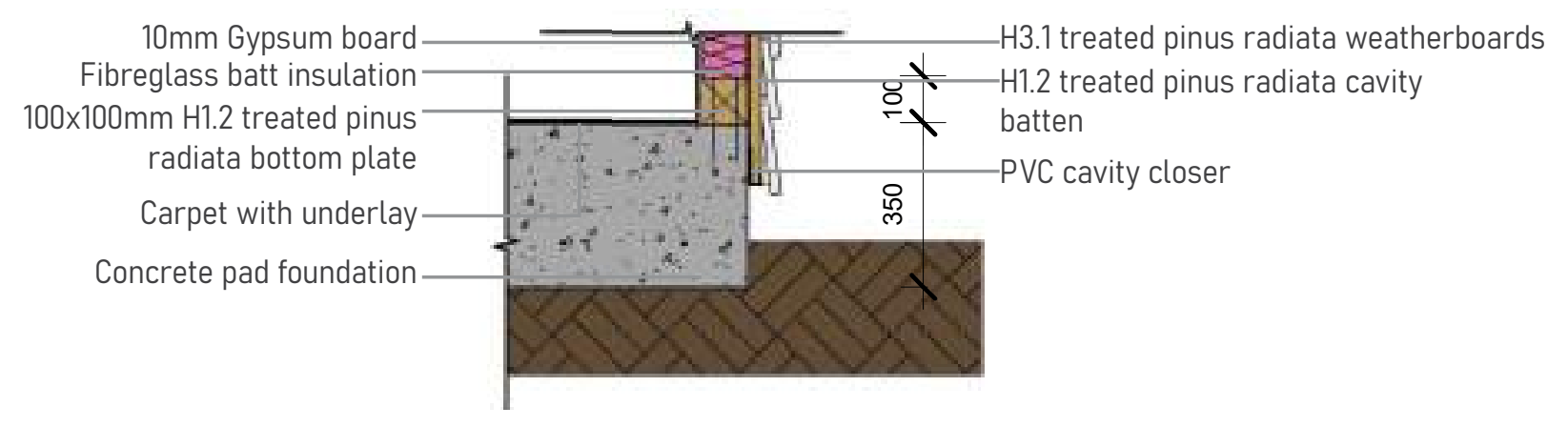




\subsection{Biodegradable and Reusable Definitions}

In order to obtain an accurate understanding of the waste generated by both designs the definition of a biodegradable or reusable component has to be clear.

Every material will eventually biodegrade; therefore, it is not whether or not a material will biodegradable but how long it will take to do so that needs to be understood. Sassi (2008) believes the European Norm (EN) 13432 standard for composting of packaging can be useful in forming a definition for the building materials (Sassi, 2008). The EN 13432 standard uses the criteria of the rate and efficiency of the biodegrading process and the quality of the resulting compost to determine biodegradability (Sassi, 2008). Regarding rate and efficiency, a material in a watery medium must convert at least $90 \%$ of the organic material into carbon dioxide within six months. Research testing of bulding meilding ainst this criterion has been carried out by the Bulding Research Establishment and given sultable preparation for composting (e.g. Shredding), months and ther show ade mon 2005) Regarding compost qualty, the standard atso at., 2005). Regarding compost quality, he standard also hazard to humans or plants (Sassi, 2008).

LVL is not biodegradable under these criteria as Love specifies that New Zealand LVL takes 23 years for $50 \%$ of its content decompose (Love, 2010).

A material is defined as reusable in this thesis if there is certainty of an identical application in another project and the material has sufficient integrity to perform in that new application without the need for alterations or repairs. Therefore, only interior elements were deemed reusable because one can be more certain of their integrity due to the absence of exposure to weather. Building elements such as doors, windows, batt insulation and screw fixings and floorboards were deemed reusable components. The precast concrete footings were also deemed reusable due to the material's durability despite its external application.
Figure 75

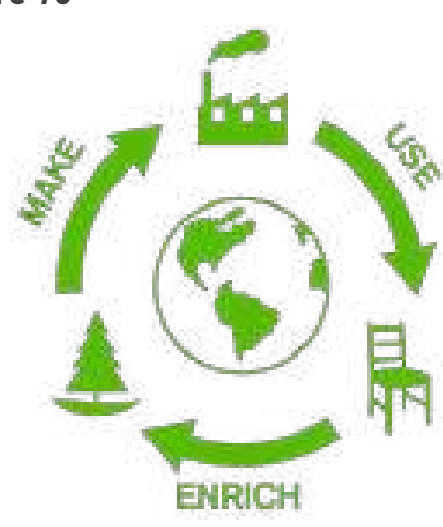

BIO-SPHERE

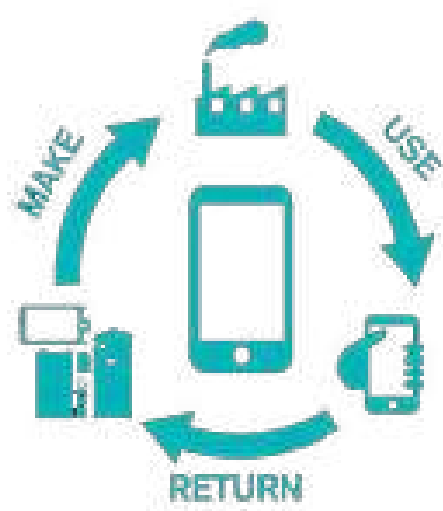

TECH-SPHERE Reprinted from "The re-use atlas : a designer's guide RIBA Publishing $P .13$ Copyright 2009 by Duncan, 2017

Brown.
Due to the scale of the building, sizing the floor joists
and bearers falls outside the scope of NZS 3604:2011. and bearers falls outside the scope of NZS 3604:2011. the floor joists likely exceed the structural capacity of Douglas-fir timber In place of steel bearers and floor joists, Douglas-fir LVL can be used. The glue in the LVL prolongs the biodegradation process as previously discussed, but not to the same time frame as a steel member. It is therefore a preferable selection. In addition, because the bearers and floor joists could not be sized joists are $350 \times 45$, spaced at $450 \mathrm{~mm}$ centres. Bearers are $350 \times 135$, spanning $1.5 \mathrm{~m}$ and spaced at $1.2 \mathrm{~m}$. 


\subsection{End of Life Analysis}

Final Design

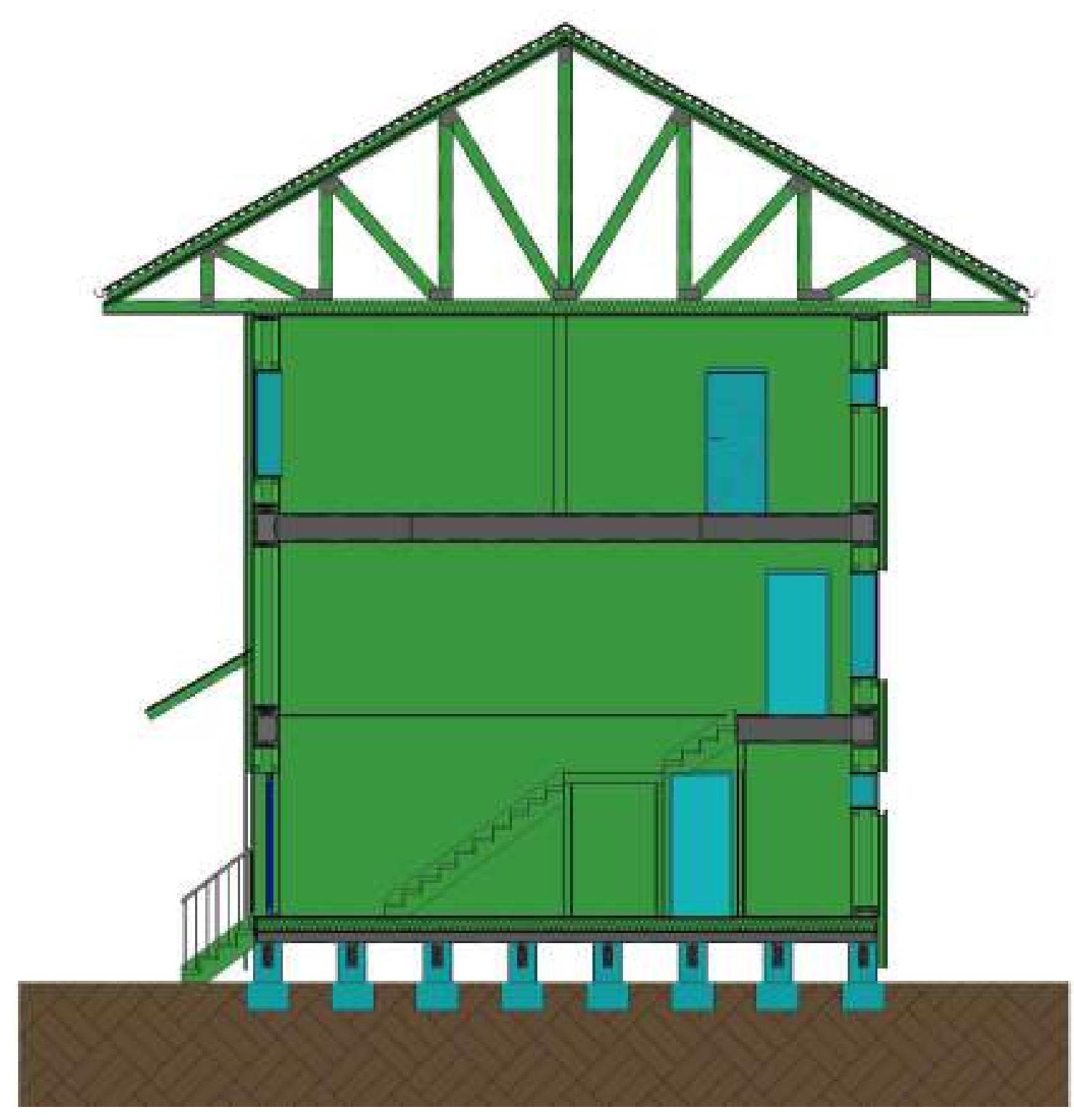

Biodegradable
+ Reusable Biodegradable Reusable Waste
Final Design with Conventional New Zealand Materials

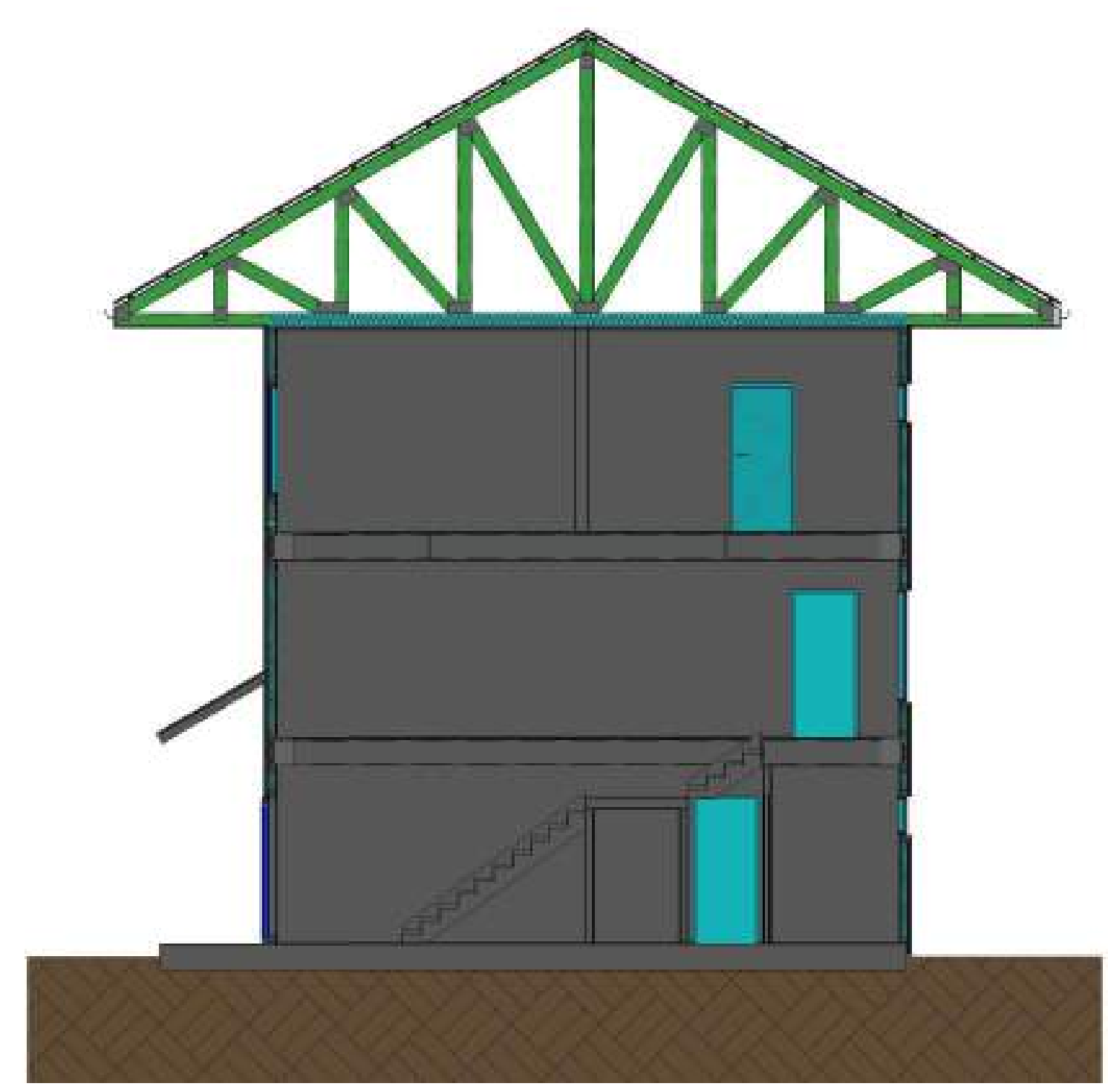

Biodegradable
+ Reusable Biodegradable Reusable Waste 
Biodegradable
+ Reusable

\begin{tabular}{|c|c|c|}
\hline Component & Material & Volume $\left(\mathrm{m}^{3}\right)$ \\
\hline Flooring Ground Floor & Untreated Matai T\&G floor boards & 5.530 \\
\hline Flooring First Floor & Untreated Matai T\&G floor boards & 2.508 \\
\hline Flooring Second Floor & Untreated Matai T\&G floor boards & 2.546 \\
\hline Ceiling Lining & Untreated Matai T\&G boards & 2.378 \\
\hline Doors interior $810 \mathrm{~mm}$ single & Solid wood Untreated Kauri Door & 2.085 \\
\hline Doors Cavity Slider & Solid wood Untreated Kauri Door & 0.281 \\
\hline Doors Double Sliding Door & Solid wood Untreated Kauri Door & 1.687 \\
\hline 140mm Interior Wall Lining & Untreated Matia T\&G boards & 4.5745 \\
\hline 230mm Interior Wall Lining & | Untreated Matia T\&G boards & 6.93875 \\
\hline Soffit & Untreated macrocarpa boards & 3.292 \\
\hline Full Height Studs & Untreated douglas-fir heartwood & 10.56 \\
\hline Sills and Lintels & Untreated douglas-fir heartwood & 1.38 \\
\hline Braces & Untreated douglas-fir heartwood & 0.45 \\
\hline Bottom Runs & Untreated douglas-fir heartwood & 1.176 \\
\hline Partial Height Studs & Untreated douglas-fir heartwood & 3.087 \\
\hline Wall Insulation & Compressed straw & 69.972 \\
\hline Box Beam Insulation & Pure wool batt insulation & 3.798 \\
\hline Wall Base Insulation & Pure wool batt insulation & 0.968 \\
\hline Exterior Wall Interior Lining & Clay plaster & 7.655 \\
\hline External Wall Vapour/Air control layer & $\sqrt{\text { Clay plaster }}$ & 7.086 \\
\hline Cavity Battens & Untreated macrocarpa heartwood & 5.698 \\
\hline Wall Cladding & Untreated macrocarpa weatherboards & 9.354 \\
\hline Underfloor Insulation & Pure wool batt insulation & 17.416 \\
\hline Ceiling Insulation & Pure wool blown-in insulation & 19.910 \\
\hline Balcony Walls & Untreated macrocarpa boards & 1.61 \\
\hline Interior Walls (Framing+Lining) & $\begin{array}{l}\text { Untreated douglas-fir heartwood framing + Untreated Matia } \\
\text { T\&G Boards }\end{array}$ & 37.815 \\
\hline Exterior Posts Big & Untreated macrocarpa heartwood & 0.695 \\
\hline Exterior Posts Small Long & Untreated macrocarpa heartwood & 3.152 \\
\hline Exterior Posts Small Short & Untreated macrocarpa heartwood & 2.126 \\
\hline Roof Trusses & Untreated douglas-fir heartwood & 36.72 \\
\hline Roof Purlins & Untreated douglas-fir heartwood & 6.435 \\
\hline Decking (ground and balconies) & Untreated macrocarpa boards & 3.52 \\
\hline Awning Roofing & Untreated western red cedar shingles & 0.161 \\
\hline Awning Framing & Untreated douglas-fir heartwood & 0.11 \\
\hline Roofing & Untreated western red cedar shingles & 9.286 \\
\hline Roof Underlay & Clay plaster & 5.694 \\
\hline
\end{tabular}

162

Table continued on page 164
Biodegradable Biodegradable Reusable

Waste

\begin{tabular}{|c|c|c|}
\hline Component & Material & Volume $\left(\mathrm{m}^{3}\right)$ \\
\hline Mechanical Fixings For Roofing & $\overline{\text { Steel }}$ & 0.446 \\
\hline Mechanical Fixings For Purlins & $\frac{\text { Steel }}{r}$ & 0.446 \\
\hline Mechanical Fixings For Rafters & $\frac{\text { Steel }}{x}$ & 0.036 \\
\hline Mechanical Fixings For Ceiling & Steel & 1.125 \\
\hline Mechanical Fixings For Cavity Battens & Steel & 0.117 \\
\hline Mechanical Fixings For Cladding & Steel & 2.347 \\
\hline Mechanical Fixings For Wall to Floor & Steel & 0.095 \\
\hline Mechanical Fixings For Flooring & $\frac{\text { Steel }}{x}$ & 2.363 \\
\hline Mechanical Fixings For Floor Framing & Steel & 0.078 \\
\hline Plywood Flooring First Floor & Plywood & 2.508 \\
\hline Plywood Flooring Second Floor & Plywood & 2.571 \\
\hline Balcony Decking & H3.2 treated pinus radiata & 2.816 \\
\hline Doors interior $810 \mathrm{~mm}$ single & Hollow core radiata pine door & 2.085 \\
\hline Doors Cavity Slider & Hollow core radiata pine door & 0.281 \\
\hline Doors double sliding door & Hollow core radiata pine door & 1.687 \\
\hline Wall Insulation & $\begin{array}{l}\text { Fibreglass Insulation (BRANZ, 2020a, Brunsdon \& Magan, } \\
\text { 2017) }\end{array}$ & 18.268 \\
\hline Ceiling Insulation & $\begin{array}{l}\text { Fibreglass Insulation (BRANZ, 2020a, Brunsdon \& Magan, } \\
\text { 2017) }\end{array}$ & 19.910 \\
\hline Balcony Walls & H3.2 treated pinus radiata & 1.61 \\
\hline Windows Type 1 & Aluminium framed window (Burgess, 2011) & 1.238 \\
\hline Windows Type 2 & Aluminium framed window (Burgess, 2011) & 0.075 \\
\hline Windows Type 3 & Aluminium framed window (Burgess, 2011) & 0.075 \\
\hline Windows Type 4 & Aluminium framed window (Burgess, 2011) & 0.075 \\
\hline Window Type 5 & Aluminium framed window (Burgess, 2011) & 0.113 \\
\hline Door Exterior entrance & Aluminium framed door & 0.48 \\
\hline Double door exterior & Aluminium framed door & 3 \\
\hline Spouting & PVC & 0.621 \\
\hline Down Pipes & PVC & 0.017 \\
\hline Carpet Ground Floor & Nylon and polyester & 1.033 \\
\hline Carpet First Floor & Nylon and polyester & 0.906 \\
\hline Carpet Second Floor & Nylon and polyester & 0.945 \\
\hline Awning Roofing & Sheet metal (Brunsdon \& Magan, 2017) & 0.161 \\
\hline Ceiling Lining & Gypsum board & 0.951 \\
\hline Soffit & Fibre Cement & 3.292 \\
\hline Full Height Studs & H1. 2 treated pinus radiata (Brunsdon \& Magan, 2017) & 4.576 \\
\hline Sills and Lintels & H1.2 treated pinus radiata (Brunsdon \& Magan, 2017) & 0.69 \\
\hline Partial Height Studs & H1.2 treated pinus radiata (Brunsdon \& Magan, 2017) & 1.548 \\
\hline
\end{tabular}


Final Design

\begin{tabular}{|l|l|l|}
\hline Roof Weatherboards & Untreated macrocarpa weatherboards & 6.825 \\
\hline Foundations & Concrete & 18.656 \\
\hline Windows Type 1 & Glass with untreated macrocarpa framing & 1.238 \\
\hline Windows Type 2 & Glass with untreated macrocarpa framing & 0.075 \\
\hline Windows Type 3 & Glass with untreated macrocarpa framing & 0.075 \\
\hline Windows Type 4 & Glass with untreated macrocarpa framing & 0.075 \\
\hline Window Type 5 & Glass with untreated macrocarpa framing & 0.113 \\
\hline Door Exterior entrance & Glazed with untreated macrocarpa framing & 0.48 \\
\hline Double door exterior & Glazed with untreated macrocarpa framing & 3 \\
\hline Spouting & PVC & 0.621 \\
\hline Down Pipes & PVC & 0.017 \\
\hline Mechanical Fixings For Roofing & Steel & 1.782 \\
\hline Mechanical Fixings For Purlins & Steel & 1.782 \\
\hline Mechanical Fixings For Rafters & Steel & 0.036 \\
\hline Mechanical Fixings For Ceiling & Steel & 1.125 \\
\hline Mechanical Fixings For Cavity Battens & Steel & 0.117 \\
\hline Mechanical Fixings For Cladding & Steel & 2.347 \\
\hline $\begin{array}{l}\text { Mechanical Fixings For Wall to Wall } \\
\text { Connections }\end{array}$ & Steel & 0.216 \\
\hline Mechanical Fixings For Wall to Floor & Steel & \\
\hline Mechanical Fixings For Flooring & Steel & 0.095 \\
\hline Mechanical Fixings For Floor Framing & Steel & 2.363 \\
\hline Steel Nail Plates For Trusses & Steel & 0.078 \\
\hline Floor Framing Ground & Untreated LVL pinus radiata & 0.047 \\
\hline Floor Framing First & Untreated LVL pinus radiata & 5.862 \\
\hline Floor Framing Second & Untreated LVL pinus radiata & 4.205 \\
\hline Bearers & Untreated LVL pinus radiata & 4.614 \\
\hline Deck Framing & Untreated LVL pinus radiata & 4.668 \\
\hline Cavity Closer & uPVC & 1.914 \\
\hline Top and Bottom Box Beams & Untreated LVL pinus radiata & 0.320 \\
\hline Panel Sides & Untreated LVL pinus radiata & 5.808 \\
\hline DPC & Polyethylene & 4.386 \\
\hline Metal Flashings & Aluminium & 0.010 \\
\hline Window Opening Tapes & SBS-modified bitumen & 0.059 \\
\hline Door Opening Tapes & SBS-modified bitumen & 0.067 \\
\hline Sealants & Silicone & 0.025 \\
\hline & & 0.013 \\
\hline
\end{tabular}

\begin{tabular}{|l|l|}
\hline $\begin{array}{l}\text { End of life } \\
\text { characteristics }\end{array}$ & Volume \\
\hline $\begin{array}{l}\text { Biodegradable + } \\
\text { Reusable }\end{array}$ & $33 \mathrm{~m}^{3}$ \\
\hline Biodegradable & $276 \mathrm{~m}^{3}$ \\
\hline Reusable & $34 \mathrm{~m}^{3}$ \\
\hline Waste & $32 \mathrm{~m}^{3}$ \\
\hline Total & $375 \mathrm{~m}^{3}$ \\
\hline
\end{tabular}

Note: Balustrade and stairs volumes were excluded from the calculations as accurate volumes are not produced by Revit for these components.

Total Volume: $\mathbf{3 7 5 . 2 7} \mathrm{m}^{3}$
Final Design with Conventional New Zealand Materials

\begin{tabular}{|l|l|l|}
\hline Top And Bottom Plates X Direction & H1.2 treated pinus radiata (Brunsdon \& Magan, 2017) & 1.428 \\
\hline Top And Bottom Plates Y Direction & H1.2 treated pinus radiata (Brunsdon \& Magan, 2017) & 1.044 \\
\hline Exterior Wall Interior Lining & Gypsum board & 3.062 \\
\hline Building Wrap & Polypropylene & 1.13 \\
\hline Cavity Battens & $\begin{array}{l}\text { H3.1 treated pinus radiata (Department of Building and } \\
\text { Housing, 2006) }\end{array}$ & 0.777 \\
\hline Wall Cladding & $\begin{array}{l}\text { H3.1 treated pinus radiata weatherboards (Brunsdon } \\
\text { Magan, 2017) }\end{array}$ & 9.354 \\
\hline 140mm Interior Wall Framing & H1.2 treated pinus radiata (Brunsdon \& Magan, 2017) & 82.341 \\
\hline 140mm Interior Wall Lining & Gypsum board & 0.9149 \\
\hline 230mm Interior Wall Framing & H1.2 treated pinus radiata (Brunsdon \& Magan, 2017) & 24.9795 \\
\hline 230mm Interior Wall Lining & Gypsum board & 1.38775 \\
\hline Exterior Posts Big & H3.2 treated pinus radiata & 0.695 \\
\hline Exterior Posts Small Long & H3.2 treated pinus radiata & 3.152 \\
\hline Exterior Posts Small Short & H3.2 treated pinus radiata & 2.126 \\
\hline Roof Trusses & H1.2 treated pinus radiata & 36.72 \\
\hline Roof Purlins & H1.2 treated pinus radiata & 1.625 \\
\hline Awning Framing & H1.2 treated pinus radiata & 0.11 \\
\hline Roofing & Sheet metal (Brunsdon \& Magan, 2017) & 9.286 \\
\hline Roof Underlay & Synthetic material & 1.238 \\
\hline Foundation & Concrete slab (Brunsdon \& Magan, 2017) & 48.841 \\
\hline Steel Nail Plates For Trusses & Steel & 0.047 \\
\hline Floor Framing First & H1.2 treated pinus radiata (Brunsdon \& Magan, 2017) & 4.205 \\
\hline Floor Framing Second & H1.2 treated pinus radiata (Brunsdon \& Magan, 2017) & 4.614 \\
\hline Deck Framing & H3.2 treated pinus radiata & 1.531 \\
\hline Cavity Closer & UPVC & 0.320 \\
\hline DPC & Polyethylene & 0.279 \\
\hline Metal Flashings & Aluminuim & 0.059 \\
\hline Window Opening Tapes & SBS-modified bitumen & 0.067 \\
\hline Door Opening Tapes & SBS-modified bitumen & 0.025 \\
\hline Sealants & Silicone & 0.013 \\
\hline & & \\
\hline
\end{tabular}

Note: Balustrade and stairs volumes were excluded from Revit for these components.

Total Volume: $321.85 \mathrm{~m}^{3}$

\begin{tabular}{|l|l|}
\hline $\begin{array}{l}\text { End of life } \\
\text { characteristics }\end{array}$ & Volume \\
\hline $\begin{array}{l}\text { Biodegradable }+ \\
\text { Reusable }\end{array}$ & $0 \mathrm{~m}^{3}$ \\
\hline Biodegradable & $0 \mathrm{~m}^{3}$ \\
\hline Reusable & $64 \mathrm{~m}^{3}$ \\
\hline Waste & $258 \mathrm{~m}^{3}$ \\
\hline Total & $322 \mathrm{~m}^{3}$ \\
\hline
\end{tabular}


End Of Life Summary

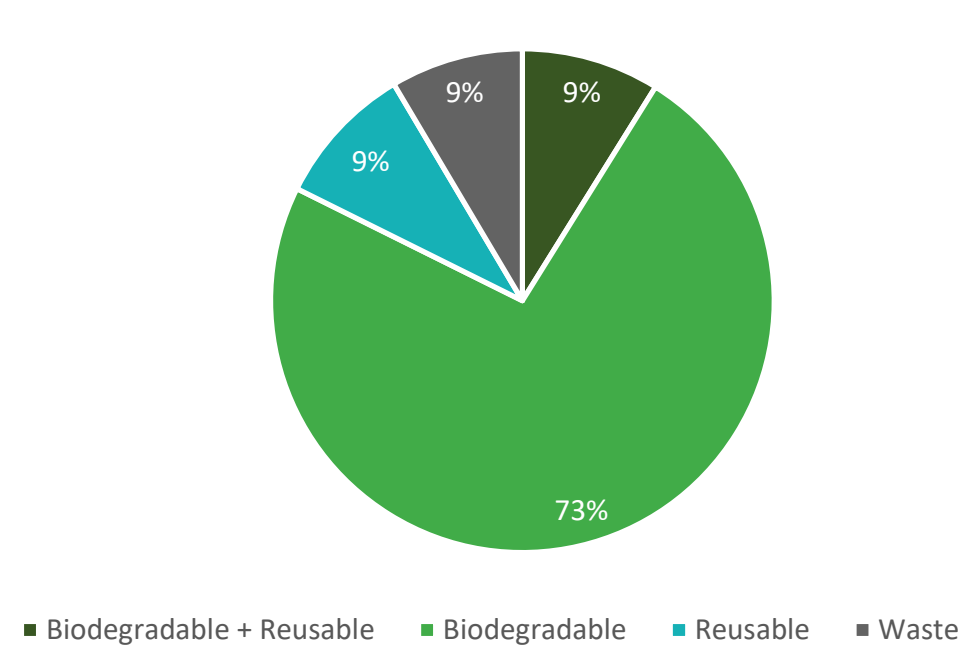

Waste Summary

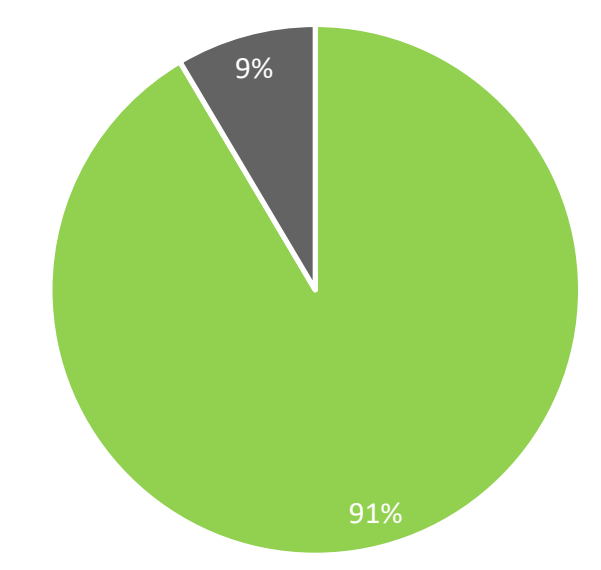

- Waste diverted from landfill - Waste to landfill

Material Breakdown

$11 \%$

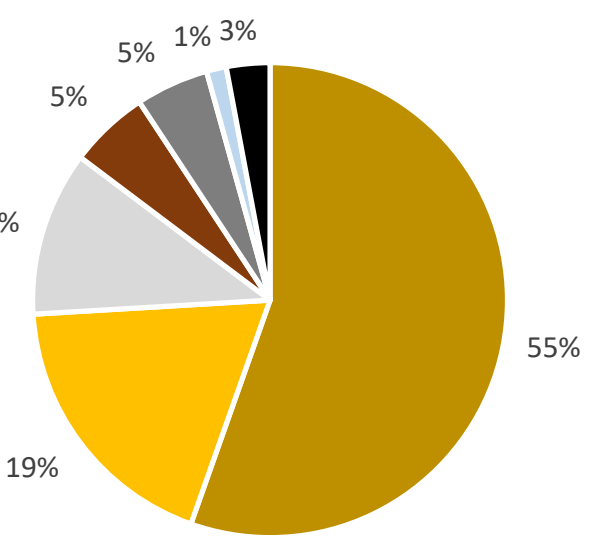

End Of Life Summary

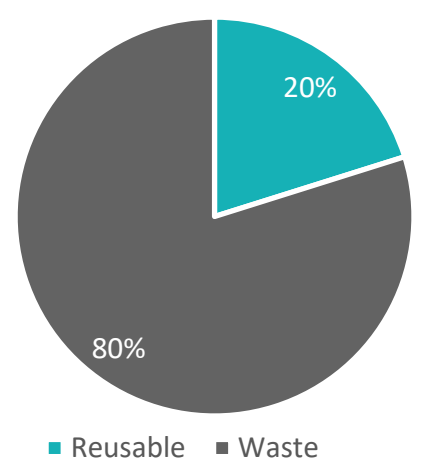

Waste Summary

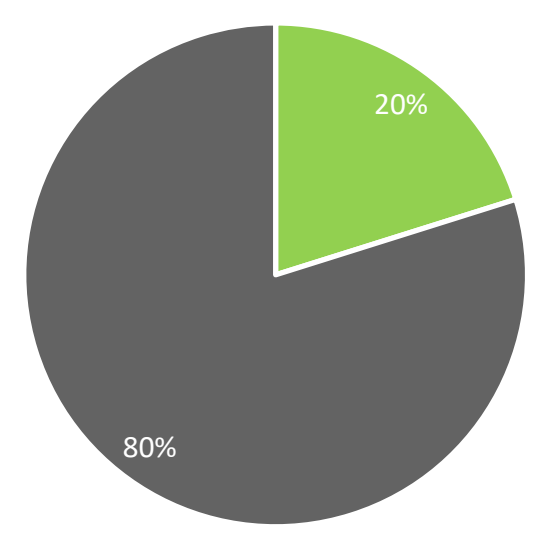

Waste diverted from landfill $\quad$ - Waste to landfill

Material Breakdown

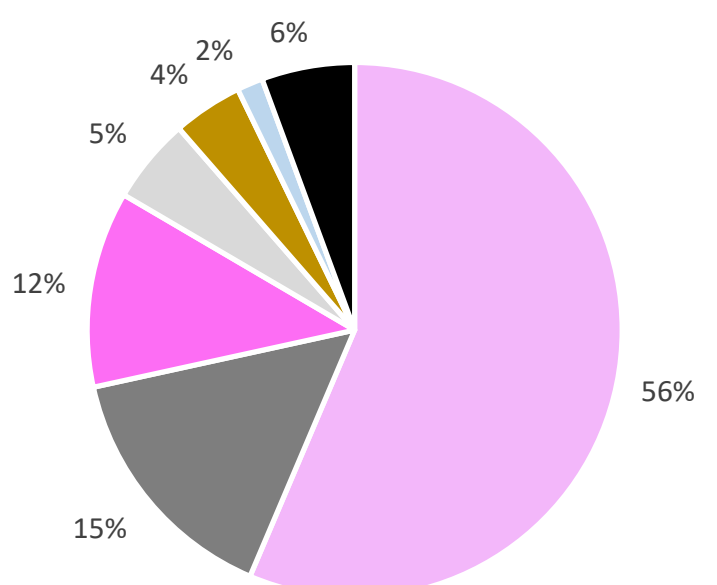


Waste Summary

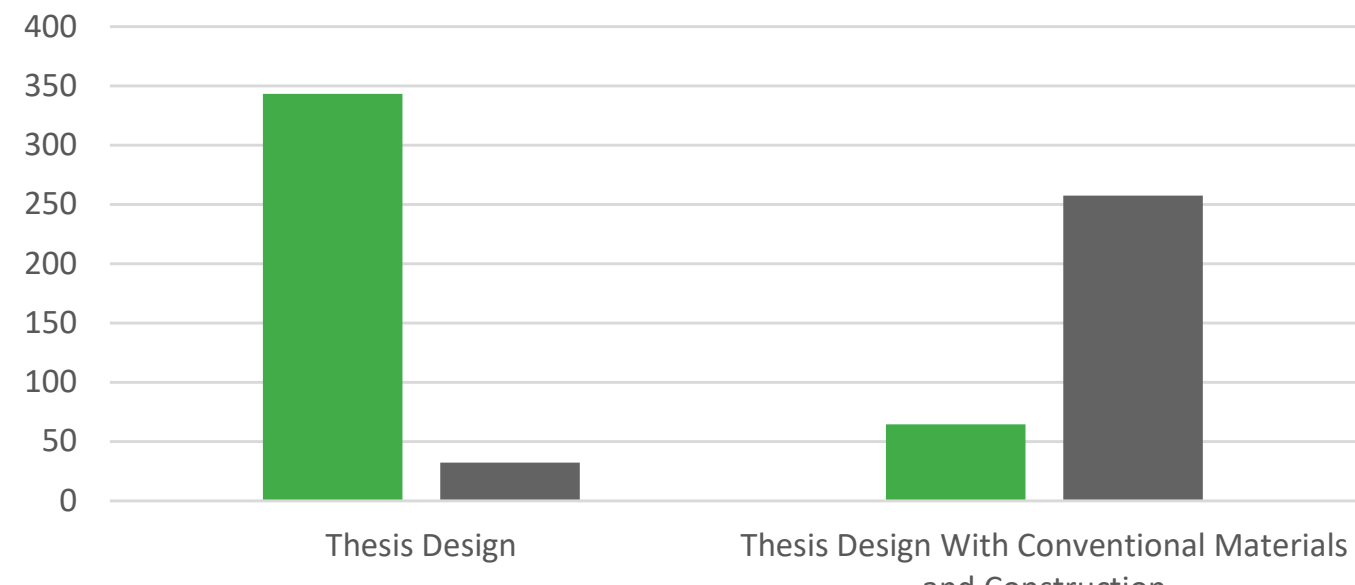

and Construction

Waste diverted from landfill - Waste to landfill

Thesis Design

\begin{tabular}{|l|l|l|}
\hline Thesis Objective & Assessment Criteria & Score \\
\hline 1. Zero Waste & $\begin{array}{l}\text { Percentage of waste diverted from } \\
\text { land fill by volume }\end{array}$ & $91 \%$ \\
\hline $\begin{array}{l}\text { 2. Maximise } \\
\text { Biodegradable Materials }\end{array}$ & $\begin{array}{l}\text { Percentage of biodegradable } \\
\text { materials by volume }\end{array}$ & $82 \%$ \\
\hline
\end{tabular}

Thesis Design with Conventional New Zealand Materials

\begin{tabular}{|l|l|l|}
\hline Thesis Objective & Assessment Criteria & Score \\
\hline 1. Zero Waste & $\begin{array}{l}\text { Percentage of waste diverted from } \\
\text { land fill by volume }\end{array}$ & $20 \%$ \\
\hline $\begin{array}{l}\text { 2. Maximise } \\
\text { Biodegradable Materials }\end{array}$ & $\begin{array}{l}\text { Percentage of biodegradable } \\
\text { materials by volume }\end{array}$ & $0 \%$ \\
\hline
\end{tabular}

\subsection{Discussion}

The primary objective of this thesis was to produce zero waste at the end of life of the building. However 100\% waste diversion was not achieved. The components that were neither biodegradable nor reusable that produced waste for this project include non-reusable mechanical fixings, engineered LVL timber (which was structurally required in places due to the scale of the building), cavity closers, DPC and flashings, tapes and sealant around windows and doors. In modern construction these components cannot be done without and no suitable biodegradable or reusable substitutes exist.

However, although zero waste was not achieved a considerable proportion of waste was diverted from landfill of $91 \%$. This an improvement of $71 \%$ over the same design using conventional New Zealand materials and construction. This research reveals that as the scale of a building increases so does the demand for stronger more durable materials like concrete and steel which are not biodegradable or reusable (steel is often recycled but no reused). Therefore, these waste reduction findings are only applicable to developments of a similar scale. Indeed, even greater waste reduction would be possible with a smaller dwelling where the use of engineered timber was not necessary.

It is important to note that while all building components categorised as waste in this thesis will end up in a landfill there is still a distinction between inert waste materials and waste materials that will continue to damage the environment in a landfill. Mineral materials such as concrete are inert and do no further damage to the environment once they are produced. Whereas materials such as chemical treated timber can damage the environment while in a landfill.

The secondary objective of this thesis was to maximise the use of biodegradable materials. The final design was comprised of $82 \%$ biodegradable materials. This is in stark contrast to the $0 \%$ present in the design using conventional New Zealand construction techniques. The final design was comprised of $55 \%$ untreated timber, $19 \%$ straw and $11 \%$ wool. Whereas, the conventional New Zealand construction design was comprised of $56 \%$ treated timber, $15 \%$ concrete and $12 \%$ fibreglass insulation. Only $4 \%$ of the conventional design was untreated timber. This highlights the degree to which the chemical treatment of timber is a barrier to waste reduction. These findings also display the opportunity to dramatically increase the proportion of biodegradable material in a dwelling by substituting inorganic insulation with an organic alternative. In addition, this research highlights the amount of waste caused by a concrete pad foundation which is now the most common fou
\& Magan, 2017).

\subsection{Techsphere Barriers}

The percentage of waste diverted from landfill of $91 \%$ for the final design remains only theoretical potential withou the requed the organic cycle and technical cycle to occur. This is the area of the construction industry that needs altering for any progress on waste reduction to be made. The main inability to facilitare deconstruction both ing industry's practice.

Regarding the design, specialist, non-removable and adhesive fixings contribute to the monolithic permanence of buildings. These fixings can be found in most houses. especially new homes as they are demanded by our highly regulated building industry (Finch et al., 2017). These fixings methods inevitably cause serious damage on removal as their ability to adhere and not be removed provides their durability. This often means that a high proportion of reclaimed material or sufficient integrity of the material cannot be ensured for reuse (Sassi, 2008). In addition, the accessibility of building components and fixings is often not considered during the design process (Sassi, 2008). Our buildings are not designed for ease of deconstruction, in fact the opposite seems true.

Regarding the practice of deconstruction, the construction industry is driven by economic efficiency and in this regard, demolition is superior to decontruction (Coelho, 2013) Th is because of the additional processes that deconstruction requires Deconstruction requires the demounting storing testing certifying and resupplying of building components (Gorgolewski, 2008). Until the construction industry is mature enough to adopt this approach zero waste will be unobtainable as deconstruction is also required for the separation of any biodegradable materials.

In addition to deconstruction, the lack of standard measures for building components means tha opportunities for reuse are specialised (Minunno et at 2018). Reuse is therefore witnessed as a niche activity and not on a mass scale. 


\section{Conclusion}

This thesis had the objectives of achieving zero waste at the end of the design's life, maximising the use of

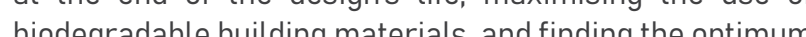
biodegradab construction approach for New Zealimum was hypothesised along with Sassi (2006) that an entirely zero-waste construction could be achieved through zero-wastion con hoth biodegradable and reusable building components. The project investigated how a MDH house

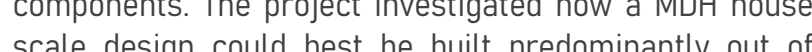
biodegradable building materials.

It was found that an entirely zero-waste construction could not be achieved as not every necessary building component could be substituted for a biodegradable or reusable alternative This confutes Sassi's hypothesis that zero waste could be achieved through a combination of biodegradable reusable components (P Sassi, 2006). Engineered timber of LVL which has a significant proportion of inorganic glue was required by structural necessity and moisture managing devices in external openings such as flashings tapes and sealants could not be done without. However, a significant proportion of waste of $91 \%$ by volume could be diverted from landfill compared to the $20 \%$ of waste by volume that could potentially be diverted from landfill for the design with a New Zealand conventional construction. This suggests that Auckland Council's goal of $60 \%$ waste reduction by 2030 is at least theoretically possible in the residential sector but the goal of 'zero waste' by 2040 is unrealistic and perhaps unobtainable

In addition, a proportion of biodegradable materials of $82 \%$ by volume was achieved for the final design in contrast to the $0 \%$ present in a conventional New Zealand construction.

The optimum biodegradable construction approach for New Lealand made use of materials that were deemed most suitable for New Zealand based on their availability and performance in New Zealand's climate and seismic context. These materials were untreated western red cedar for roofing, untreated Douglas fir heartwood for structurat framing, straw bale and pure wool for insulation, clay or lime-based plasters as well as untreated macrocarpa, redwood or red beech cladding for cladding, untreated matai, macrocarpa or red beech for flooring. Reusable foundations were the most suitable to provide suficient durability such as precast footing, piles or strip foundations as well as screw piles. The optimum construction approach for the external walls of the bullding using straw and wool insulation that are susceptible to moisture was prefabricated wall panels.

\section{Limitations}

This is because of the benefits of reduced construction waste, the dry interior environment and the potential for improved construction accuracy and guality assurance. The success of existing prefabricated straw wall panels from Ecococon and Modcell also demonstrates the ability of this construction technique to increase the abtake of biodegradable insulation materials in the modern construction industry. A new prefabricated wall pan was proposed informed by literature and the existing prefabricated straw wall panel precedents of Ecococon and Modcell that includes pure wool batt insulation in the panel's timber hollow box beams used as top and bottom plates.

The form of the building design was primarily driven by the needs of the biodegradable materials which is principally the need to keep the straw and wool insulation free from moisture. The design, therefore, had large eave overhangs of $2 \mathrm{~m}$ and balconies of the upper storeys to protect the walls from rain. The design also had minimal external junctions (2.6 exterior junctions/dwelling) in order to minimise potential areas of construction failure where moisture infiltration could occur. The design had a dwelling density of 294 bedrooms/hectare

The building design was then integrated on site to architecturally test the building design. A site was also integrated to demonstrate the potential of the biodegradable material construction for application in an urban setting at the MDH scale. The final design was sited in Upper Hutt Wellington, but the construction approaches from the design can be applied to any site and architectura typologies of a similar scale.

Most of the New Zealand population would be unaware of the potential to build their future dwellings from environmental benefits that flow from doing so. This project increases awareness of the opportunity that exists to uttise the abundance of the biodegradable materials of timber, straw, wool and clay in New Zealand to miligate the issue of construction and demolition waste in our country
While the proportion of biodegradable materials that one builds with in New Zealand can be significantly increased it will come at a significantly increased cost which will likely be the a sign of bi be the sable materials and by extension waste reduction. It is also important to note that while the final design final design uses more material for the same floor area as the conventional design due to its thicker walls Resource conservation, despite whether or not the material is renewable is an important sustainability consideration.

Finally, even though the biodegradable cladding and roofing materials used in the design for this thesis meet the durability requirements of the NZBC they will require more maintenance than conventional alternatives.

\section{Further Research}

Further research into the hygrothermal performance and the constructablity of the proposed straw and wool prefabricated wall panel is necessary. Hygrothermal simulation of the panel in a program such as Wufi would provide greater confidence in the panel's performance in New Zealand's climate than the simple hand thermal and vapour resistance calculations performed in this thesis. In addition, 1:1 scale built prototypes of the panels would allow a more thorough analysis of the panel's construction and connections.

In addition, only waste and closed loop categories were calculated for this project, but if more time was available a life-cycle assessment as well as an analysis of embodied energy and emitted $\mathrm{CO}_{2}$ of the final design would further this research.

Finally, this research has revealed that despite the unavailability of cork, mycelium, bamboo, wood fibre insulation and cellulose insulation in New Zealand, they are materials that would perform well in our climate and seismic context. There is an opportunity for these biodegradable building materials to be produced in New Zealand in the future and therefore research into how to integrate these materials into a construction suitable to
New Zealand would be beneficial. 


\section{Reference List}

Akhtar, A., \& Sarmah, A. K. (2018). Construction and demolition waste generation and properties of recycled aggregate concrete. A global perspective. Jounal of Cleaner Production, 186, 262-281. https://doi.org/10.1016/j. clepro.2018.03.085

Auckland Council. (2014). Low Carbon Auckland. https:// www.aucklandcouncil.govt.nz/plans-projects-policiesreports-bylaws/ourplans- strategies/topic-basedplans-strategies/environmental-plans-strategies/ docslowcarboncopy/low-carbon-strategic-actionplanfull. pdf

Auckland Council. (2018). Auckland Waste Management and Minimisation Plan 2018. https://www. aucklandcouncil.govt. $\mathrm{nz} / \mathrm{plans}$-projects-policies-reports-bylaws/our-plansstrategies/topic-based-plans-strategies/environmenta-
plans-strategies/docswastemanagementplan/aucklandplans-strategies/docswastemanagementpla
waste-management-minimisation-plan.pdf

Baker-Brown, D. (2017). The re-use atlas: A designer's guide towards the circular economy. RIBA Publishing.

Black Mountain Insulation. (2020). NatuWool Technical Sheet. https://www.blackmountaininsulation.com/ NatuWool_Technical_Sheet.pdf

BRANZ. (2013). Key historical dates for timber treatment regimes. https://www.branz.co.nz/cms_show_download

BRANZ. (2014). REBRI guides introduction. https://www. branz.co.nz/cms_display.php?st=1\&sn=113

BRANZ. (2015). Straw Bale.

BRANZ. (2017a). Attitudes towards MDH.

BRANZ. (2017b). What is medium-density housing?

BRANZ. (2020a). TIMBER SHINGLE AND SHAKE ROOFING, https://www.abodo.co.nz/resource/Downloads/BRANZBulletin-648-Timber-Shingles-and-Shakes-Abodo-Wood. pdf

BRANZ. (2020b). Timber Treatment. https://www weathertight.org.nz/new-buildings/timbertreatment/\#h3-4

Brunsdon, N., \& Magan, C. (2017). Physical characteristics of new houses 2017. BRANZ.

Bryson, K. (2017). The New Zealand housing preferences survey. Attitudes towards medium-density housing BRANZ.

Carradine, D., Smith, T., Moroder, D., O'Neill, E., Quintan Gallo, P., \& Shelton, R. (2019). Multi-Storey Light TimberFramed Buildings in New Zealand-Engineering Design BRANZ.

Champion, C. (2009). Seismic Response of Innovative Straw Bale Wall Systems and System Identification Georgia Institute of Technology.

Chini, A. R. (2001). Deconstruction and Materials Reuse Technology, Economic, and Policy.

Coelho, A. (2013). Conventional demolition versus deconstruction techniques in managing construction an and demolition waste (pp. 141-185). Elsevier.

DensGlass ${ }^{\circledR}$. (2017). DensGlass ${ }^{\circledR}$ Sheathing Technical Guide. Georgia-Pacific.

Dougoud, M. (2018). Mycelium Infrastructures for Impermanent Futures [Master's, University of Washington] http.//search.proquest.com/doc

Ecococon. (2017). ENVIRONMENTAL PRODUCTDECLARATION (EPD) EcoCocon Straw Modules (Panels).

Ecococon. (2020, February 13). Ecococon-Our Story. Ecococon. https://ecococon.eu/us/blog/2020/ecococonour-story

Ecopanel. (2018). What are Ecopanels made of? Ecopanel. https://www.ecopanel.co.nz/faq

Ferguson, G. (1994). Building the New Zealand Dream. Dunmore Press with the assistance of the Historical Branch, Department of ...

Galle, W., Temmerman, N. D., \& Meyer, R. D. (2017). Integrating Scenarios into Life Cycle Assessment: Understanding the Value and Financial Feasibility of a

Ganotopoulou, E. (2014). Biodegradable materials: A research and design handbook; enhancing the use of biodegradable materials on building's envelopes in the Netherlands.

Gorgolewski, M. (2008). Designing with reused building components: Some challenges.
Hall, M. (2012). Earth and Straw Bale: An Investigation of Their Performance and Potential as Building Materials in New Zealand

Hall, M. (2014). Is there a place for natural building in New Zealand's conventional housing market? - A prefabricated straw bale case study. 26

Hall, M. (2015). Guidelines for strawbale construction in New Zealand

Hall, M. (2019). Counting straw: The capacity of New Zealand's grain growing sector to supply straw for construction.

Haug, R. (2018). The practical handbook of compost engineering. Routledge.

Henry, M. (2012). The Original Nebraska Straw Bale Buildings.

Hobbs, G., McMahon, V., Harrex, R. M., \& Swainson, M. (2005). Composting in the Construction Industry. Building Research Establishment.

Hsiaw, J. S. (2010). Seismic load-resisting capacity of plastered straw bale walls. Massachusetts Institute of Technology.

Hutching, G. (2018). US company buys NZ wool for home insulation. https://www.stuff.co.nz/business/105955733/ us-company-buys-large-tonnage-of-nz-wool-for-homeinsulation

saacs, N. (2009). Stable Foundations. BRANZ. https:// www. buildmagazine.org.nz/assets/PDF/B112-86BuildingHistory-Foundations.pdf?

Isaacs, N. (2010a). Timber framing-rapid and reliable. Build.

saacs, N. (2010b). Keeping warm with rainbows of colour. BRANZ. 1982

Jaycock, S. (2014). Toward healthier, sustainable, medium density housing, through a return to natural materials.

Kennedy, J. F., Smith, M. G., \& Wanek, C. (2014). The Art of Natural Building-Second Edition-Completely Revised,
Expanded and Updated: Design, Construction, Resources . com/lib/vuw/detalt.action?doclD=5180757

Kimberley, M. O., McKinley, R. B., Cown, D. J., \& Moore, J. R. (2017). Modelling the variation in wood density of $\mathrm{Ne}$ Zealand-grown Douglas-fir. New Zealand Journal of

King, B. (2006). Design of straw bale buildings: The state of the art. Green Books.

Kordziel, S., Glass, S. V. Boardman, C. R., Munson, R. A Zelinka, S. L., Pei, S. \& Tabares-Velasco, P. C. (2020) Hygrothermal characterization and modeling of crosslaminated timber in the building envelope. Building and .

Love, S. (2010). Carbon Footprint of New Zealand Laminated Veneer Lumber.

Macarthur, R. S. (1994). The Cork Oaks and Cork: A New Zealand Perspective. RS Macarthur.

Magwood, C. (2016). Essential Prefab Straw Bale Construction: The Complete Step-by-Step Guide. New Society Publishers. http://ebookcentral.proquest.com/lib/ vuw/detailaction?docl $\mathrm{D}=4560615$

Maxit. (n.d.). Maxit Straw Insulating Panels.

McDonough, W., \& Braungart, M. (2002). Cradle to cradle Remaking the way we make things. North point press.

Ministry for the Environment. (2002). The New Zealand Waste Strategy. Towards zero waste and a sustainable New Zealand. Ministry for the Environment, Wellington New Zealand.

Ministry for the Environment (2012). Medium-density Housing Case Study Assessment Methodology.

Ministry for the Environment. (2019). Reducing waste: A more effective landfill levy.

Minunno, R., O'Grady, T., Morrison, G., Gruner, R., \& Colling M. (2018). Strategies for Applying the Circular Economy to Prefabricated Buildings.

ModCell@. (2020). ModCell ${ }^{\circledR}$ Projects. ModCell® Straw Technology. https://www.modcell.com/projects/

Morton, T., Stevenson, F., Taylor, B., \& Smith, C. (2005). Low cost earth brick construction. Arc Chartered Architects, 
construction. Building Research \& Information, 36(5). 509-519.

Nicol, A., \& Saunders, C. (2008). Meat and wool-Wool production and processing. https://teara.govt.nz/en/ meat-and-wool/page-6

North, G. (2002). Strawbale Building Guidelines for Wet and Humid Climates. https://www.ecodesign.co.nz/files/7/ STRAWBALE_BUILDING_GUIDELINES_FOR_WET_AND HUMID_CLIMATES_as_in_New_Zealand_-_aka_straw_bale_

Omondi, S. (2017). The World's Top Wool Producing Countries. https://www.worldatlas.com/articles/the-

Overton, G. (2015). Water Vapour in Wall. BRANZ.

Parisio, S. (2006). Arsenic \& Old Landfills: What we have learned from post-closure groundwater monitoring at in Arsenic and Landfills: Protecting Water Oulity. United

Phillipps. W. J. (1952). Maori houses and food stores (Issue 8). Government Printer, South Africa.

Pringle, R. (2016). Straw into Gold

Pringle, T. (2012). Timber Treatment. BRANZ.

Pringle, T. (2013). Membanes do matter. 2.

Pringle, T. (2017). Timber weatherboards.

Racusin, J. Deva. (2012). The natural building companion: A comprehensive guide to integrative design and construction. Chelsea Green Publishing.

Rael, R. (2009). Earth architecture. Princeton architectural press.

Sigmund, B., \& Mijatovic, M. (2019). Straw boid: Climatefriendly straw house. https://www.detail.de/artike/ strohboid-klimafreundliches-strohhaus-34813/

Standards New Zealand. (2011). NZS 3604:2011 New Zealand Standard Timber-framed buildings.

Statistics New Zealand. (2017). Dwelling and Household Estimates: September 2017 quarter - tables. http:// archive.stats.govt.nz/browse_for_stats/population/

Storey, J., Gjerde, M., Charleson, A., \& Pedersen, M. (2005). The State of Deconstruction in New Zealand. Centre for Building Performance research, Victoria University, New Zealand.

TenWolde, A., McNatt, J. D., \& Krahn, L. (1988). Thermal properties of wood and wood panel products for use in buildings. Oak Ridge National Lab., TN (USA); Forest Service, Madison, WI (USA). Forest

Tuzcu, T. M. (2007). Hygro-thermal properties of sheep wool insulation.

USG Boral. (2019). USG Boral Sheetrock HD Technical Data Sheet.

Vares, O., Ruus, A., Raamets, J., \& Tungel, E. (2017). Determination of hygrothermal performance of clay政 vapour permeability. Energy Procedia, 132, 267-272.

Wilson, J. (2005). History-Māori arrival and settlement https://teara.govt.nz/en/history/page-1

Wilson, J. (2017). South Canterbury region-Early European history. Te Ara - the Encyclopedia of New Zealand. http:// www.TeAra.govt.nz/en/photograph/11336/te-waimatecuddy

Rhodes, S., \& Dolan, L. (2013). Recovery and disposal options for treated timber.

Salmond, J. (2010). Building Materials-Early Houses. http://www.TeAra.govt.nz/en/building-materials/page-1

Sassi, P. (2006). Biodegradable Building. WIT Transactions on Ecology and the Environment, 87. https://doi. org/10.2495/DN060091

Sassi, Paola. (2008). Defining closed-loop material cycle

Witten, K., Abrahamse, W., \& Stuart, K. (2011). Growth misconduct? Avoiding sprawl and improving urban intensification in New Zealand. Urban Policy and Research, 29(4), 435-442. 


\section{Appendices}

Thesis Design Volume Calculations

\begin{tabular}{|c|c|c|c|c|c|c|c|}
\hline \multirow[b]{2}{*}{ Component } & \multirow[b]{2}{*}{ Number } & \multicolumn{2}{|l|}{ Area } & \multirow[b]{2}{*}{ Depth } & \multirow[b]{2}{*}{ Volume (m3) } & \multirow[b]{2}{*}{ Material Type } & \multirow[b]{2}{*}{ Notes } \\
\hline & & Width & Height & & & & \\
\hline Flooring Ground Floor & 2 & \multicolumn{2}{|l|}{110.609} & 0.025 & 5.530 & Untreated Timber & \\
\hline Flooring First Floor & 1 & \multicolumn{2}{|l|}{100.312} & 0.025 & 2.508 & Untreated Timber & \\
\hline Flooring Second Floor & 1 & \multicolumn{2}{|l|}{101.853} & 0.025 & 2.546 & Untreated Timber & \\
\hline Ceiling Lining & 3 & 11.72 & 8.115 & 0.025 & 7.133 & Untreated Timber & \\
\hline Doors interior $810 \mathrm{~mm}$ single & 13 & 0.81 & 1.98 & 0.1 & 2.085 & Untreated Timber & \\
\hline Doors Cavity Slider & 2 & 0.71 & 1.98 & 0.1 & 0.281 & Untreated Timber & \\
\hline Doors double sliding door & 6 & 1.42 & 1.98 & 0.1 & 1.687 & Untreated Timber & \\
\hline 140mm Interior Wall Lining & 2 & \multicolumn{2}{|l|}{91.49} & 0.025 & 4.575 & \begin{tabular}{|l} 
Untreated Timber \\
\end{tabular} & \\
\hline 230mm Interior Wall Lining & 2 & \multicolumn{2}{|l|}{138.775} & 0.025 & 6.939 & Untreated Timber & \\
\hline Soffit & 1 & \multicolumn{3}{|l|}{3.292} & 3.292 & Untreated Timber & \\
\hline Full Height Studs & 240 & \multicolumn{3}{|l|}{0.044} & 10.56 & Untreated Timber & \\
\hline Sills and Lintels & 92 & \multicolumn{3}{|l|}{0.015} & 1.38 & \begin{tabular}{|l} 
Untreated Timber \\
\end{tabular} & \\
\hline Braces & 30 & \multicolumn{3}{|l|}{0.015} & 0.45 & Untreated Timber & \\
\hline Bottom Runs & 24 & \multicolumn{3}{|l|}{0.049} & 1.176 & Untreated Timber & \\
\hline Partial Height Studs & 343 & \multicolumn{3}{|l|}{0.009} & 3.087 & \begin{tabular}{|l} 
Untreated Timber \\
\end{tabular} & \\
\hline Wall Insulation & & & & & 69.972 & \begin{tabular}{|l|} 
Straw \\
\end{tabular} & \\
\hline Box Beam Insulation & 6 & 0.3 & 0.05 & 42.2 & 3.798 & Wool & \\
\hline Wall Base Insulation & 3 & 0.045 & 0.17 & 42.2 & 0.968 & Wool & \\
\hline Exterior Wall Interior Lining & 1 & \multicolumn{2}{|l|}{306.2} & 0.025 & 7.655 & Clay & \\
\hline External Wall Vapour/Air control layer & & & & & 7.086 & Clay & \\
\hline Cavity Battens & 259 & \multicolumn{3}{|l|}{0.022} & 5.698 & Untreated Timber & \\
\hline Wall Cladding & 1 & \multicolumn{2}{|l|}{311.8} & 0.03 & 9.354 & Untreated Timber & \\
\hline Underfloor Insulation & & & & & 17.416 & Wool & \\
\hline Ceiling Insulation & 1 & 12.47 & 8.87 & 0.18 & 19.910 & \begin{tabular}{|l|l} 
Wool \\
\end{tabular} & \\
\hline Balcony Walls & 10 & \multicolumn{3}{|l|}{0.161} & 1.61 & Untreated Timber & \\
\hline $230 \mathrm{~mm}$ Interior Wall Framing & 0.35 & \multicolumn{2}{|l|}{138.775} & 0.18 & 8.743 & Untreated Timber & Assumed timber framing is approxiamtely $35 \%$ of the wall area \\
\hline 140mm Interior Wall Framing & 0.35 & \multicolumn{2}{|l|}{91.49} & 0.9 & 28.819 & Untreated Timber & Assumed timber framing is approxiamtely $35 \%$ of the wall area \\
\hline Exterior Posts Big & 4 & 0.14 & 0.14 & 8.86 & 0.695 & Untreated Timber & \\
\hline Exterior Posts Small Long & 52 & 0.14 & 0.05 & 8.66 & 3.152 & \begin{tabular}{|l} 
Untreated Timber \\
\end{tabular} & \\
\hline Exterior Posts Small Short & 52 & 0.14 & 0.05 & 5.84 & 2.126 & Untreated Timber & \\
\hline Roof Trusses & 40 & \multicolumn{3}{|l|}{0.918} & 36.72 & Untreated Timber & \\
\hline Roof Purlins & 99 & \multicolumn{3}{|l|}{0.065} & 6.435 & \begin{tabular}{|l} 
Untreated Timber \\
\end{tabular} & \\
\hline Decking (ground and balconies) & 5 & 28.16 & & 0.025 & 3.52 & Untreated Timber & \\
\hline Awning Roofing & 1 & & & & 0.161 & \begin{tabular}{|l} 
Untreated Timber \\
\end{tabular} & \\
\hline Awning Framing & 10 & 0.011 & & & 0.11 & \begin{tabular}{|l} 
Untreated Timber \\
\end{tabular} & \\
\hline Roofing & 1 & 9.286 & & & 9.286 & Untreated Timber & \\
\hline
\end{tabular}




\begin{tabular}{|c|c|c|c|c|c|c|c|}
\hline \multirow[b]{2}{*}{ Component } & \multirow[b]{2}{*}{ Number } & \multicolumn{2}{|l|}{ Area } & \multirow[b]{2}{*}{ Depth } & \multirow[b]{2}{*}{ Volume (m3) } & \multirow{2}{*}{\begin{tabular}{|l} 
Material Type \\
$T / S / W / C L / G L / C N / 0$
\end{tabular}} & \multirow[b]{2}{*}{ Notes } \\
\hline & & Width & Height & & & & \\
\hline Roof Underlay & 39 & \multicolumn{3}{|l|}{0.146} & 5.694 & Clay & \\
\hline Roof Weatherboards & 39 & \multicolumn{3}{|l|}{0.175} & 6.825 & Untreated Timber & \\
\hline Foundations & 88 & \multicolumn{3}{|l|}{0.212} & 18.656 & Concrete & \\
\hline Windows Type 1 & 11 & 1.5 & 1.5 & 0.05 & 1.238 & Glass & \\
\hline Windows Type 2 & 1 & 1 & 1.5 & 0.05 & 0.075 & Glass & \\
\hline Windows Type 3 & 1 & 1.5 & 1 & 0.05 & 0.075 & Glass & \\
\hline Windows Type 4 & 2 & 1.5 & 0.5 & 0.05 & 0.075 & Glass & \\
\hline Door Exterior entrance & 2 & 1.2 & 2 & 0.1 & 0.48 & Glass & \\
\hline Double door exterior & 10 & 1.5 & 2 & 0.1 & 3 & Glass & \\
\hline Spouting & 2 & 20.7 & 0.15 & 0.1 & 0.621 & Other & \\
\hline Down Pipes & 2 & 9.22 & \multicolumn{2}{|l|}{0.001} & 0.017 & Other & \\
\hline Mechanical Fixings For Roofing & 3960 & \multicolumn{3}{|l|}{0.00045} & 1.782 & Other & 1 per purlin (fixing assume $0.015 \times 0.015 \times 0.2$ ) \\
\hline Mechanical Fixings For Purlins & 3960 & \multicolumn{3}{|l|}{0.00045} & 1.782 & Other & Fixing into each truss \\
\hline Mechanical Fixings For Rafters & 80 & \multicolumn{3}{|l|}{0.00045} & 0.036 & Other & Trusses fixed to tops of walls \\
\hline Mechanical Fixings For Ceiling & 2500 & \multicolumn{3}{|l|}{0.00045} & 1.125 & Other & 1 per truss per 140 board \\
\hline Mechanical Fixings For Cavity Battens & 259 & \multicolumn{3}{|l|}{0.00045} & 0.117 & Other & 4 per cavity batten \\
\hline $\begin{array}{l}\text { Mechanical Fixings For Wall to Wall } \\
\text { Connections }\end{array}$ & 480 & \multicolumn{3}{|l|}{0.00045} & 0.216 & Other & 5 fixing from inside and out per wall join \\
\hline Mechanical Fixings For Wall to Floor & 210 & \multicolumn{3}{|l|}{0.00045} & 0.095 & Other & Every $600 \mathrm{~mm}$ on each floor \\
\hline Mechanical Fixings For Flooring & 5250 & \multicolumn{3}{|l|}{0.00045} & 2.363 & Other & Every joist for every 140 board for every floor \\
\hline Mechanical Fixings For Floor Framing & 174 & \multicolumn{3}{|l|}{0.00045} & 0.078 & Other & Every timber connection (average 29 joists per floor) \\
\hline Steel Nail Plates For Trusses & 1280 & 0.068 & 0.18 & 0.003 & 0.047 & Other & 1 plate on both sides per timber connection per truss \\
\hline Floor Framing Ground & & & & & 5.862 & Untreated Timber & \\
\hline Floor Framing First & & & & & 4.205 & Untreated Timber & \\
\hline Floor Framing Second & & & & & 4.614 & Untreated Timber & \\
\hline Bearers & 8 & 0.35 & 0.135 & 12.35 & 4.668 & \begin{tabular}{|l} 
Untreated Timber \\
\end{tabular} & \\
\hline Deck Framing & 5 & \multicolumn{3}{|l|}{0.383} & 1.914 & Untreated Timber & \\
\hline Cavity Closer & 3 & 42.68 & 0.05 & 0.05 & 0.320 & Other & \\
\hline Top and Bottom Box Beams & 24 & \multicolumn{3}{|l|}{0.242} & 5.808 & Untreated Timber & \\
\hline Panel Sides & 86 & \multicolumn{3}{|l|}{0.051} & 4.386 & Untreated Timber & \\
\hline DPC & 88 & 0.135 & 0.4 & 0.002 & 0.010 & Other & Between every bearer and concrete footing \\
\hline Metal Flashings & 28 & 0.01 & 0.14 & 1.5 & 0.059 & Other & 1 per head of every exterior opening (approximated dimensions as openings vary slightly) \\
\hline Window Opeing Tapes & 64 & 0.35 & 0.002 & 1.5 & 0.067 & Other & 4 per window. 1 per corner of opening (dimensions of tape are approximate) \\
\hline Door Opening Tapes & 24 & 0.35 & 0.002 & 1.5 & 0.025 & Other & 2 per door. 1 per corner of opening (dimensions of tape are approximate) \\
\hline
\end{tabular}


Thesis Design with Conventional New Zealand Materials Volume Calculations

\begin{tabular}{|c|c|c|c|c|c|c|c|}
\hline \multirow[b]{2}{*}{ Component } & \multirow[b]{2}{*}{ Number } & \multicolumn{2}{|l|}{ Area } & \multirow[b]{2}{*}{ Depth } & \multirow[b]{2}{*}{ Volume (m3) } & \multirow[b]{2}{*}{ Material Type } & \multirow[b]{2}{*}{ Notes } \\
\hline & & Width & Height & & & & \\
\hline Mechanical Fixings For Roofing & 990 & \multicolumn{3}{|c|}{0.00045} & 0.4455 & Metal & 11 per purlin (fixing assume $0.015 \times 0.015 \times 0.2$ ) \\
\hline Mechanical Fixings For Purlins & 990 & \multicolumn{3}{|l|}{0.00045} & 0.4455 & Metal & \begin{tabular}{|l|l|} 
Fixing into each truss \\
\end{tabular} \\
\hline Mechanical Fixings For Rafters & 80 & \multicolumn{3}{|l|}{0.00045} & 0.036 & Metal & Trusses fixed to tops of walls \\
\hline Mechanical Fixings For Ceiling & 2500 & \multicolumn{3}{|l|}{0.00045} & 1.125 & Metal & 1 per truss per 140 board \\
\hline Mechanical Fixings For Cavity Battens & 259 & \multicolumn{3}{|l|}{0.00045} & 0.11655 & Metal & 4 per cavity batten \\
\hline Mechanical Fixings For Cladding & 5215 & \multicolumn{3}{|l|}{0.00045} & 2.34675 & Metal & 1 per weather board per cavity batten \\
\hline Mechanical Fixings For Wall to Floor & 210 & \multicolumn{3}{|l|}{0.00045} & 0.0945 & Metal & Every $600 \mathrm{~mm}$ on each floor \\
\hline Mechanical Fixings For Flooring & 5250 & \multicolumn{3}{|l|}{0.00045} & 2.3625 & Metal & Every joist for every 140 board for every floor \\
\hline Mechanical Fixings For Floor Framing & 174 & \multicolumn{3}{|l|}{0.00045} & 0.0783 & Metal & Every timber connection (average 29 joists per floor) \\
\hline Plywood Flooring First Floor & 1 & \multicolumn{2}{|l|}{100.312} & 0.025 & 2.5078 & Untreated Timber & \\
\hline Plywood Flooring Second Floor & 1 & \multicolumn{2}{|l|}{102.853} & 0.025 & 2.57133 & Untreated Timber & \\
\hline Balcony Decking & 4 & \multicolumn{2}{|l|}{28.16} & 0.025 & 2.816 & Untreated Timber & \\
\hline Doors interior $810 \mathrm{~mm}$ single & 13 & 0.81 & 1.98 & 0.1 & 2.08494 & Untreated Timber & \\
\hline Doors Cavity Slider & 2 & 0.71 & 1.98 & 0.1 & 0.28116 & Untreated Timber & \\
\hline Doors double sliding door & 6 & 1.42 & 1.98 & 0.1 & 1.68696 & Untreated Timber & \\
\hline Wall Insulation & & & & & 18.268 & Fibre Glass & Total is 30.616 before framing and lining subtraction \\
\hline Ceiling Insulation & 1 & 12.47 & 8.87 & 0.18 & 19.90960 & Fibre Glass & \\
\hline Balcony Walls & 10 & \multicolumn{3}{|l|}{0.161} & 1.61 & Untreated Timber & \\
\hline Windows Type 1 & 11 & 1.5 & 1.5 & 0.05 & 1.2375 & Glass & \\
\hline Windows Type 2 & 1 & 1 & 1.5 & 0.05 & 0.075 & Glass & \\
\hline Windows Type 3 & 1 & 1.5 & 1 & 0.05 & 0.075 & Glass & \\
\hline Windows Type 4 & 2 & 1.5 & 0.5 & 0.05 & 0.075 & Glass & \\
\hline Window Type 5 & 1 & 1.5 & 1.5 & 0.05 & 0.1125 & Glass & \\
\hline Door Exterior entrance & 2 & 1.2 & 2 & 0.1 & 0.48 & Glass & \\
\hline Double door exterior & 10 & 1.5 & 2 & 0.1 & 3 & Glass & \\
\hline Spouting & 2 & 20.7 & 0.15 & 0.1 & 0.621 & Other & \\
\hline Down Pipes & 2 & 9.22 & \multicolumn{2}{|l|}{0.0009} & 0.01660 & Other & \\
\hline Carpet Ground Floor & 1 & \multicolumn{2}{|l|}{103.304} & 0.01 & 1.03304 & Other & Carpet with underlay. Approximated over total interior area but not under walls \\
\hline Carpet First Floor & 1 & \multicolumn{2}{|l|}{90.574} & 0.01 & 0.90574 & Other & Carpet with underlay. Approximated over total interior area but not under walls \\
\hline Carpet Second Floor & 1 & \multicolumn{2}{|l|}{94.504} & 0.01 & 0.94504 & Other & \\
\hline Awning Roofing & 1 & & & & 0.161 & Metal & \\
\hline Ceiling Lining & 3 & 11.72 & 8.115 & 0.01 & 2.85323 & Other & \\
\hline Soffit & 1 & \multicolumn{3}{|l|}{3.292} & 3.292 & Other & \\
\hline Full Height Studs & 104 & 0.044 & & & 4.576 & Treated Timber & \\
\hline Sills and Lintels & 46 & 0.015 & & & 0.69 & Treated Timber & \\
\hline Partial Height Studs & 172 & 0.009 & & & 1.548 & Treated Timber & \\
\hline Top And Bottom Plates X Direction & 12 & 0.119 & & & 1.428 & Treated Timber & \\
\hline Top And Bottom Plates Y Direction & 12 & 0.087 & & & 1.044 & Treated Timber & \\
\hline
\end{tabular}




\begin{tabular}{|c|c|c|c|c|c|c|c|}
\hline \multirow[b]{2}{*}{ Component } & \multirow[b]{2}{*}{ Number } & \multicolumn{2}{|l|}{ Area } & \multirow[b]{2}{*}{ Depth } & \multirow[b]{2}{*}{ Volume (m3) } & \multirow[b]{2}{*}{ Material Type } & \multirow[b]{2}{*}{ Notes } \\
\hline & & Width & Height & & & & \\
\hline Exterior Wall Interior Lining & 1 & \multicolumn{2}{|l|}{306.2} & 0.01 & 3.062 & Other & \\
\hline External Wall Vapour/Air control layer & & & & & 1.13 & Other & \\
\hline Cavity Battens & 259 & \multicolumn{3}{|l|}{0.003} & 0.777 & Treated Timber & \\
\hline Wall Cladding & 1 & \multicolumn{2}{|l|}{311.8} & 0.03 & 9.354 & Treated Timber & \\
\hline 140mm Interior Wall Framing & 0.35 & \multicolumn{2}{|l|}{91.49} & 0.9 & 82.341 & Treated Timber & \\
\hline 140mm Interior Wall Lining & 2 & \multicolumn{2}{|l|}{91.49} & 0.01 & 0.9149 & Other & \\
\hline 230mm Interior Wall Framing & 0.35 & \multicolumn{2}{|l|}{138.775} & 0.18 & 24.9795 & Treated Timber & \\
\hline 230mm Interior Wall Lining & 2 & \multicolumn{2}{|l|}{138.775} & 0.01 & 1.38775 & Other & \\
\hline Exterior Posts Big & 4 & 0.14 & 0.14 & 8.86 & 0.69462 & Treated Timber & \\
\hline Exterior Posts Small Long & 52 & 0.14 & 0.05 & 8.66 & 3.15224 & Treated Timber & \\
\hline Exterior Posts Small Short & 52 & 0.14 & 0.05 & 5.84 & 2.12576 & Treated Timber & \\
\hline Roof Trusses & 40 & \multicolumn{3}{|l|}{0.918} & 36.72 & Treated Timber & \\
\hline Roof Purlins & 25 & \multicolumn{3}{|l|}{0.065} & 1.625 & Treated Timber & \\
\hline Awning Framing & 10 & \multicolumn{3}{|l|}{0.011} & 0.11 & Treated Timber & \\
\hline Roofing & 1 & \multicolumn{3}{|l|}{9.286} & 9.286 & Metal & \\
\hline Roof Underlay & 1 & \multicolumn{3}{|l|}{1.238} & 1.238 & Other & \\
\hline Concrete Pad & 1 & \multicolumn{3}{|l|}{48.841} & 48.841 & Concrete & \\
\hline Steel Nail Plates For Trusses & 1280 & 0.068 & 0.18 & 0.003 & 0.04700 & Metal & 1 plate on both sides per timber connection per truss \\
\hline Floor Framing First & & & & & 4.205 & Treated Timber & \\
\hline Floor Framing Second & & & & & 4.614 & Treated Timber & \\
\hline Deck Framing & 4 & \multicolumn{3}{|l|}{0.3827} & 1.5308 & Treated Timber & \\
\hline Cavity Closer & 3 & 42.68 & 0.05 & 0.05 & 0.3201 & Other & \\
\hline DPC & 1 & \multicolumn{2}{|l|}{139.545} & 0.002 & 0.27909 & Other & under concrete slab \\
\hline Metal Flashings & 28 & 0.01 & 0.14 & 1.5 & 0.0588 & Metal & $\begin{array}{l}1 \text { per head of every exterior opening (approximated dimensions as openings vary } \\
\text { slightly) }\end{array}$ \\
\hline Window Opeing Tapes & 64 & 0.35 & 0.002 & 1.5 & 0.0672 & Other & 4 per window. 1 per corner of opening (dimensions of tape are approximate) \\
\hline Door Opening Tapes & 24 & 0.35 & 0.002 & 1.5 & 0.0252 & Other & 2 per door. 1 per corner of opening (dimensions of tape are approximate) \\
\hline Sealants & 28 & 0.01 & 0.01 & 4.5 & 0.0126 & Other & around every opening (dimensions of sealant are approximate) \\
\hline Total (2dp) & & & & & 321.85 & & \\
\hline
\end{tabular}

